SOCIO-SPATIAL ORDER OF NEOLIBERAL AHMEDABAD

Sejal Rajnikant Patel 
Graduation committee:

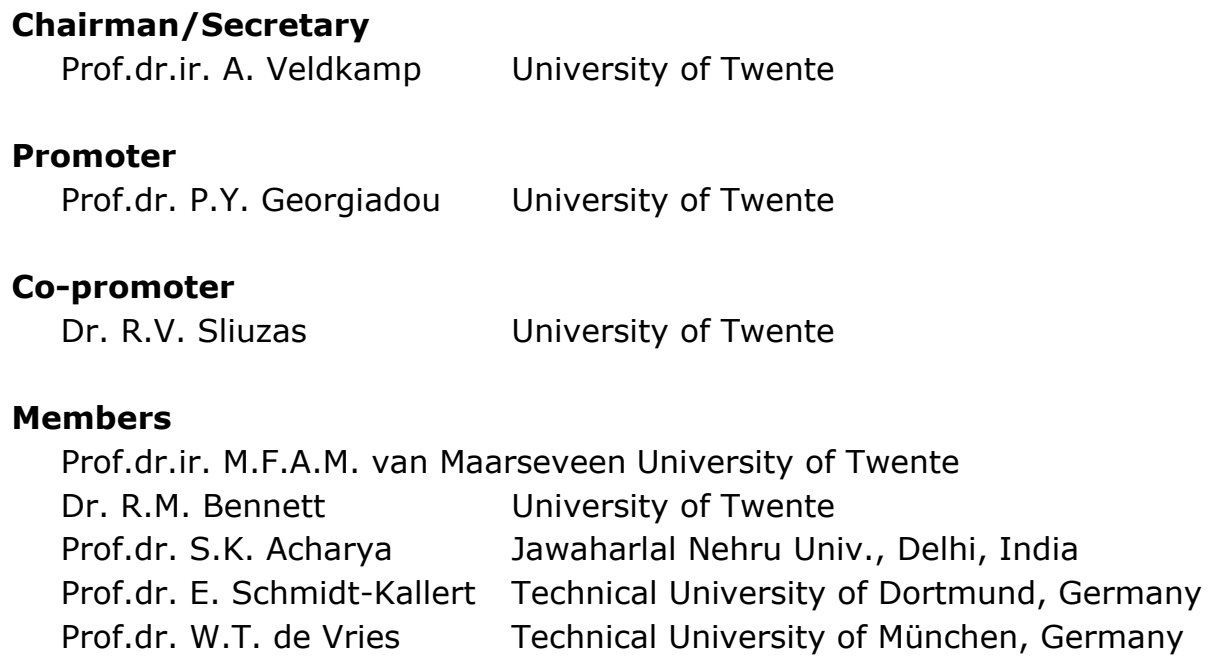

ITC dissertation number 296

ITC, P.O. Box 217, 7500 AA Enschede, The Netherlands

ISBN 978-90-365-4261-6

DOI $10.3990 / 1.9789036542616$

Cover designed by Benno Masselink Printed by ITC Printing Department Copyright (c) 2016 by Sejal Patel

TE FACULTY OF GEO-INFORMATION SCIENCE AND EARTH OBSERVATION 


\title{
SOCIO-SPATIAL ORDER OF NEOLIBERAL AHMEDABAD
}

\author{
DISSERTATION
}

to obtain

the degree of doctor at the University of Twente, on the authority of the rector magnificus, prof.dr. T.T.M. Palstra, on account of the decision of the graduation committee, to be publicly defended on Wednesday 14 December 2016 at 11.00 hrs

by

Sejal Rajnikant Patel

born on $18^{\text {th }}$ October 1971

in Ahmedabad, India 
This thesis is approved by

Prof.dr. P.Y. Georgiadou, Promoter

Dr. R.V. Sliuzas, Co-Promoter

Dr. N. Mathur, Co-Promoter 


\section{Acknowledgements}

The last but not the least important task is to acknowledge the support of mentors, colleagues, friends and family who have contributed to the culmination of this thesis. Though nearly an impossible task to thank everybody who was directly or indirectly involved, I will try my best. It has been a considerably long journey riddled with personal and scientific experiences that have enriched my life and changed me as a person. It has been a journey with highs and lows, interspersed with moments of happiness but also of frustration and despair. It has been a journey of scientific investigation but also of self-discovery where I my strengths, weaknesses and finally learnt to be at peace with myself.

It has been an honour to have a supervisory team who kept faith and belief in me all these years. Prof. Yola Georgiadou and Dr. Richard Sliuzas, this thesis would not have been possible without you. Yola, you have redefined mentorship. Your selfless dedication to scientific research and students' progress and impeccable time management is inspirational. Your prompt responses and critical feedback and often the much needed shove helped me finish the thesis draft. In the initial stage of my journey, from an opinionated practitioner to a researcher, your reminders on 'difference between opinion and research' sensitized me to the role of a researcher.

Richard, you were my most resolute support while I was in Netherlands and also in India. Words are not adequate to express the strength I derived from you during personal and scientific trials and tribulations in these years. Thank you for your unconditional support and for keeping faith. I deeply cherish your brilliant suggestions on concepts, emphasis on scientific details and precise narrative style during endless exchange of chapter drafts.

I extend my appreciation for the steadfast support of a mentor and friend, Dr. Navdeep Mathur. He has witnessed and contributed to my journey from a positivist urban planning practitioner to an interpretivist urbanist. Thank you for being the sounding board, the critique and the editor. I have been enriched from our many discussions in our offices, cafes and kitlis over the years on my research and on the state of affairs in the world.

I am indebted to the European Commission for the Erasmus Mundus fellowship to carry out research at ITC. Prof. Martin van Maarseveen was my first contact in ITC. Thank you for your warmth and guidance in the initial days, for introduction to the right people and for keeping the faith through the years that I will see this through. Thanks to Monika, Javier, Mark, Liza, Arvind, Frans for being warm and wonderful colleagues in PGM. I will cherish the numerous conversations with David Rossitier on India and China in the cafeteria. 
I am deeply grateful to Petra Weber and Loes Colenbrander for steadfast and efficient support in every PhD related issue, Marion Pierik for efficiently coordinating the financial issues, Paul van Dijk for listening to the PhD woes patiently, Theresa for meticulously handling the bureaucratic issues and Carla Gerritsen for the library support. There was no book in the world that was not in Carla's reach or no query on Endnote that she could not answer. Andrea and Tina thank you for your friendship and warm welcomes on my return after long gaps. Aiko and Gerrits Polman from the IT-helpdesk are the Samaritans of PhD journeys. They have solved endless IT related issues with patience and a smile.

Being at ITC is a culturally enriching experience given the different nationalities and cultural diversity of colleagues and students. I am fortunate to have friends who shared their ideas about various things, life experiences and of course, food! Divyani, Maitreyi (birdy) and Priya, thank you for being the family in NL. Divyani, thank you for your nurturing and standing by me in the toughest moments, for being the 3 am friend. Words are not adequate to express how much your friendship has contributed to the culmination of my PhD. Birdy, thank you for being the listener, for patiently allowing us to chat non-stop and for being the giver. Priya, thanks for all the support. Fangfang and Pu Hao were the best office-mates and we shared memorable times in and out of office. Christine thank you for the sarcastic humor over you-know-what over the years that allowed us to laugh our way through adversities. The unwinding of the Dutch umbrella by hapless scientists will be remembered by us and others for a long time. Sincere thanks to my friends Yamini, Gaurav, Tanmoy, Liang, Xuanmei, Flavia, Parveen, Paresh, Mitava, Devashree, Noor, Ahmad, Abdul, Talat and Remi. I really cherish the enjoyable (and sometimes stressful!) times we shared together in ITC.

Friends and colleagues at CEPT have contributed in different ways in culmination of my PhD. Saswat, Ashwini, Shrawan, Dr. Ray, Vishal, Anil, Mona, Utpal, Madhu, Subrangshu have cheered and encouraged through the highs and lows over the years, brainstormed with me over concepts, empirical findings and discoveries and critically read through the draft papers. Thank you for being part of my journey.

Finally, I express my deepest gratitude towards my family. Mom and dad have set an example of extraordinary spirit in life where age does not fade away the passion for life. Your positivity, fortitude and resolute intellectual, emotional and moral support have helped me sail through life and this journey. I dedicate my thesis to you. My sister Nisha, brother-in-law Vijay and nephew Aditya have been eternal sources of love and support. Heartfelt thanks to uncles, aunts and cousins whom I could count on for anything, anywhere and anytime. Thank you all for your prayers and for the implicit confidence in me. 


\section{Table of Contents}

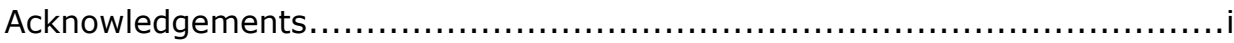

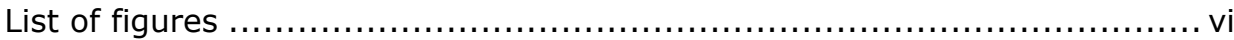

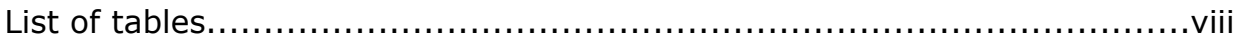

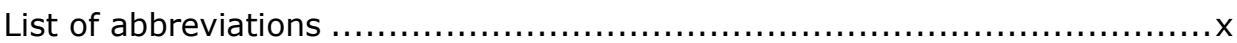

Chapter 1 Understanding issues and the context.............................

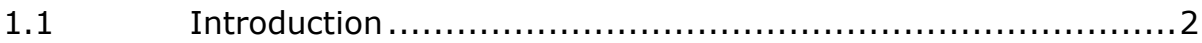

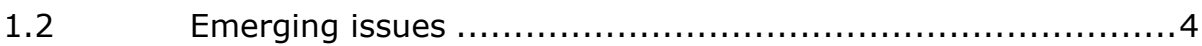

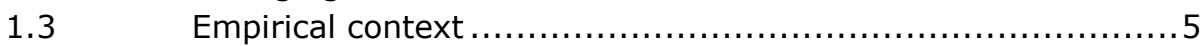

1.3.1 Decentralisation and participatory governance framework in India and implementation in Gujarat and Ahmedabad ...........5

1.3.2 Economic liberalisation and globalisation policy in India ..........7

1.3.3 Neoliberalisation and globalisation in Gujarat ................... 7

1.3.4 Neoliberal turn in governance in Ahmedabad ................... 11

1.3.5 Indian Constitution and the judiciary's stance on shelter

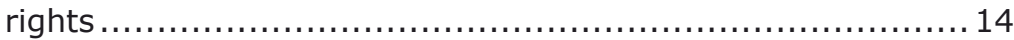

$1.4 \quad$ Stance of Ahmedabad Municipal Corporation on slums.......... 21

1.4.1 The changing stance of AMC on right to basic services......... 23

1.4.2 The changing stance of AMC on shelter rights $\ldots \ldots \ldots \ldots \ldots \ldots .23$

1.4.3 Neoliberal socio-spatial reconfiguration and consequences? ... 26

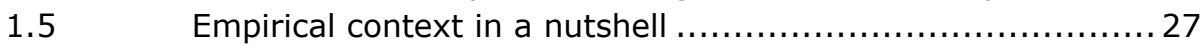

Chapter 2 Theoretical framework and research strategy $\ldots \ldots \ldots \ldots \ldots \ldots \ldots \ldots \ldots \ldots \ldots \ldots$

$2.1 \quad$ Review of extant literature on key concepts $\ldots \ldots \ldots \ldots \ldots \ldots \ldots \ldots \ldots \ldots \ldots$

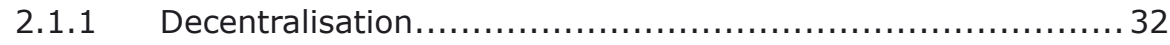

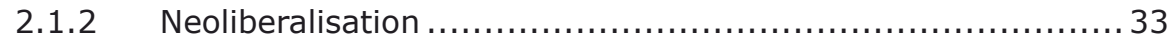

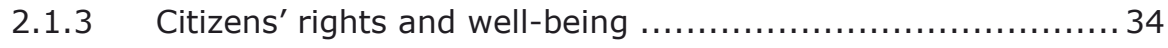

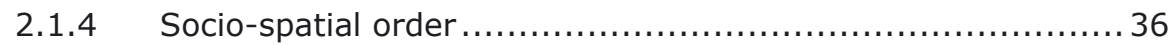

2.2 Review of extant literature on key relationships................ 36

2.2.1 Consequences of decentralisation on citizens' rights, well-being and social inequalities .............................. 36

2.2.2 Consequences of neoliberalisation for citizens' rights,

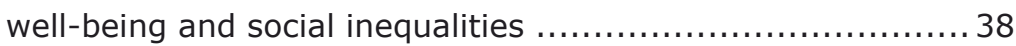

2.2.3 Consequences of neoliberalisation for a city's socio-spatial

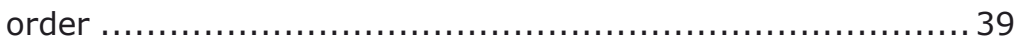

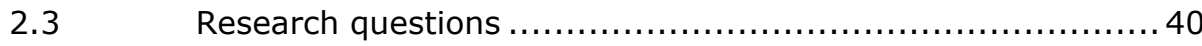

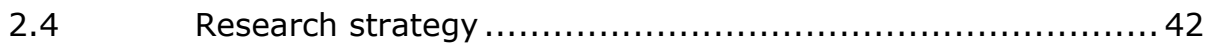

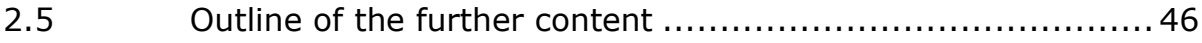

Chapter 3 Participatory local governance in Ahmedabad : invited, closed or claimed spaces for urban poor? ..........................................49

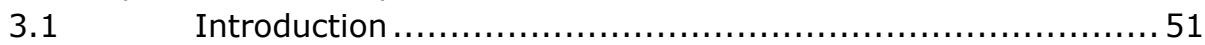

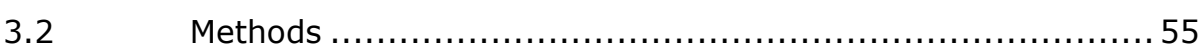

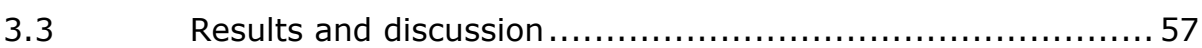

3.3.1 Implementation of national government mandate by 


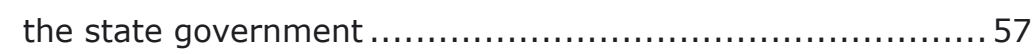

3.3.2 Implementation of participatory governance by Ahmedabad

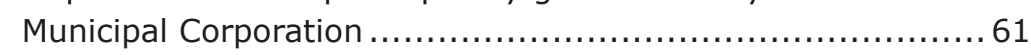

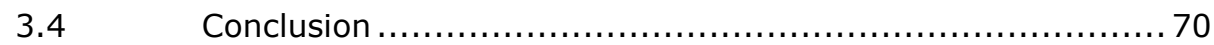

Chapter 4 Claiming shelter rights for the unpropertied citizens in a

neoliberal city: is the judiciary aligned with the state's ideology? .......73 73

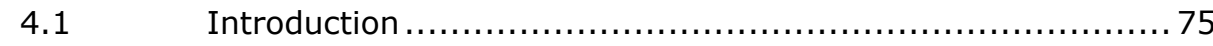

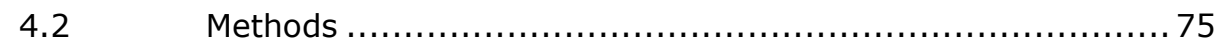

4.3 The petition on right to shelter and revision of the cutt-off

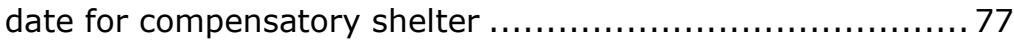

4.4 The petition on right to basic services and commodification

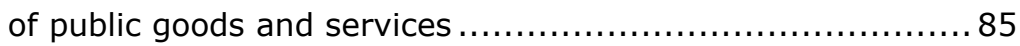

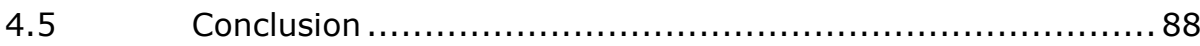

Chapter 5 The risk of impoverishment in urban development-induced displacement and resettlement in Ahmedabad .............................. 91

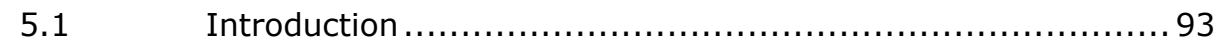

5.1.1 Understanding Development-Induced Displacement and Resettlement in India ..................................... 94

5.1.2 Development-Induced Displacement and Resettlement in

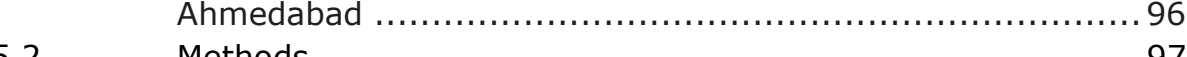

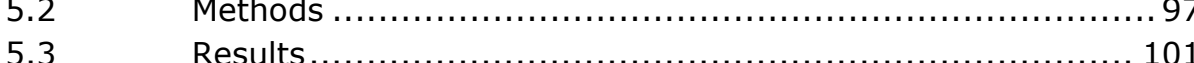

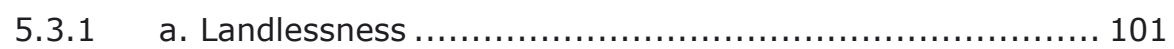

5.3 .2 b. Joblessness ................................................... 104

5.3 .3 c. Homelessness ................................................ 105

5.3.4 d. Loss of access to community facilities (education and

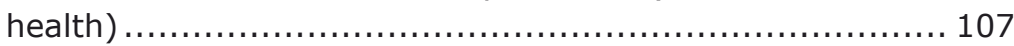

5.3.5 e. Health risks (morbidity and mortality, food insecurity) ... 110

5.3 .6 f. Marginalization ......................................... 111

5.3.7 g. Social disarticulation ..................................... 111

5.3.8 h. Uncertainty (in the pre-dispossession processes) ......... 114

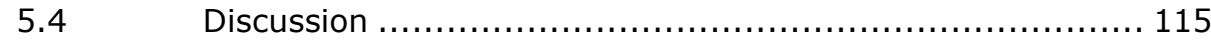

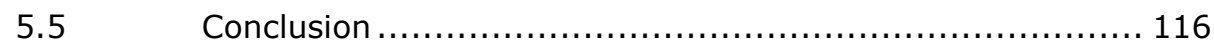

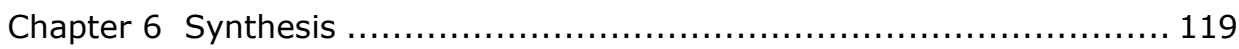

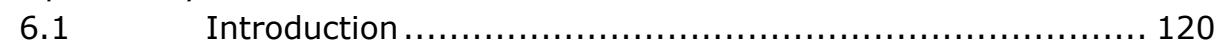

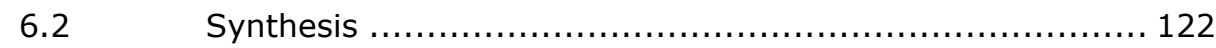

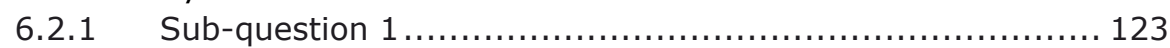

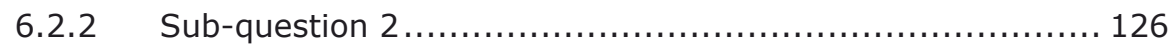

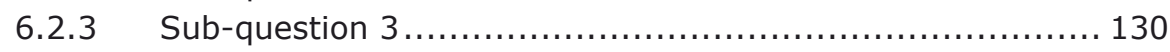

6.2.4 Main question .............................................. 135

Chapter 7 Catalysing citizen participation through information

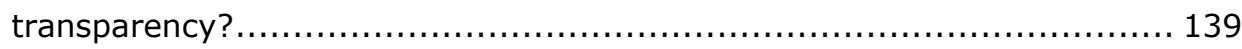

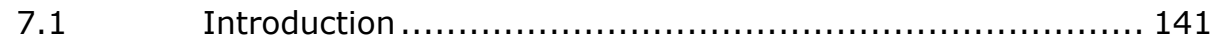

7.2 Review of extant literature on information transparency ..... 142 
7.2.1 Rise of open government and typology of transparency policies........................................................... 142

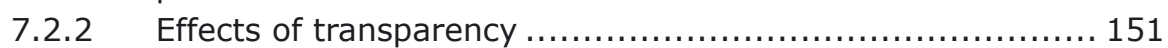

7.2.3 Assumptions of transparency ............................... 152

7.3 Empirical context: realities of opacity ......................... 153

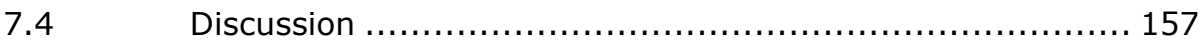

Chapter 8 Reflection and future directions................................ 161

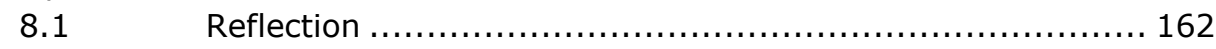

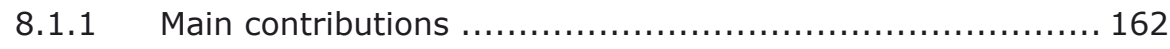

$8.1 .2 \quad$ Limitations of the study ....................................... 165

8.2 Future research directions and implications for governance. 165

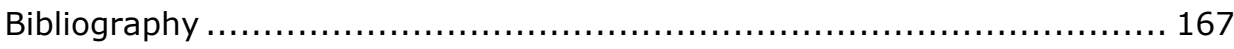

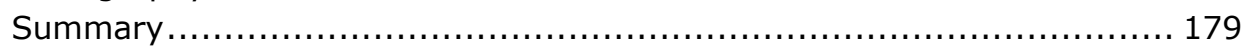

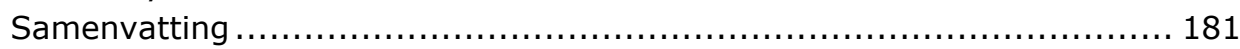

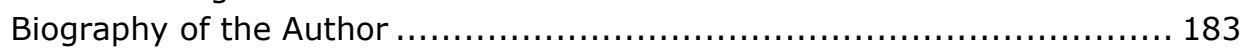

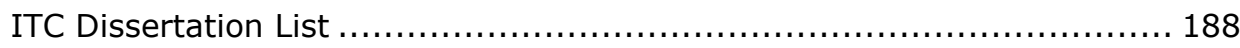

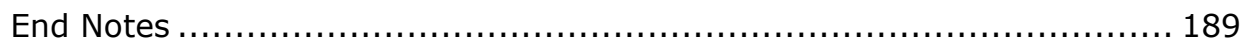




\section{List of figures}

Figure 1: Shift in tagline of Vibrant Gujarat summit from 2003 to $2015 \ldots \ldots 10$

Figure 2: Master Plan of riverfront development project ................... 12

Figure 3: Redeveloped section on riverfront after eviction of slums.......... 12

Figure 4: Vibrant Summit celebrations in the redeveloped Kankaria

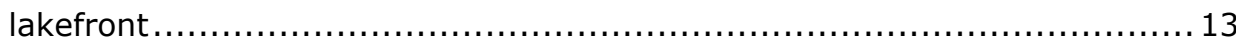

Figure 5: Slum displacement under Kankaria lakefront development........ 13

Figure 6: Locations of slums (2010 survey) and displacement inducing projects (BRTS, Riverfront and lakefront development) ............................. 26 Figure 7: Slums to be displaced by projects (BRTS, Riverfront and lakefront

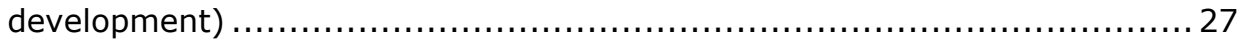

Figure 8: Slums eligible for compensatory shelter on eviction (1976 surveyed

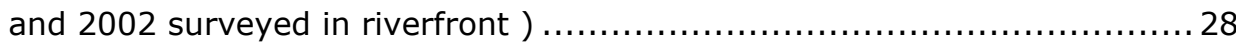

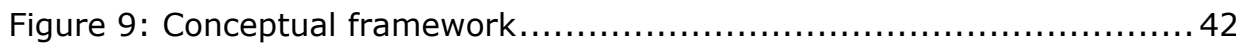

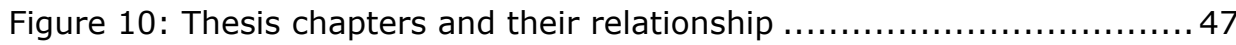

Figure 11: Distribution of semi-structured interviews of key stakeholders in

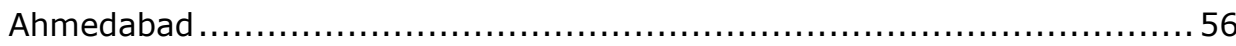
Figure 12: Proposed structure by GoI for participatory platforms under CPL reform primer of JNNURM.................................................... 59 Figure 13: AMC Structure after the mandate for ward committees and area sabhas .... .63

Figure 14: Relationship between marginalised population composition in a ward (as \% of ward population) and per capita ward budget in 2013 and 2014 budgets .....

Figure 15: Satellite images of 2001 and 2010 showing a slum displacement under Lakefront Development, Ahmedabad ................................ 97

Figure 16: Displacement and resettlement patterns on interim and permanent (BSUP) sites and sample distribution.................................... 99 Figure 17: Average, median and mode of distance of relocation of slum household from departure slum to interim and BSUP sites................... 101 Figure 18: Mapping of pattern and distance of relocation of displaced households to interim and BSUP sites.................................. 103

Figure 19: Quality of interim site and its services and shelter .............. 106

Figure 20: Physical manifestation of social disarticulation: abuse of common

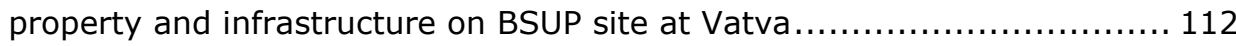

Figure 21: A poignant event in the Sabarmati riverfront................... 120

Figure 22: Summary of neoliberal shifts in Ahmedabad.................... 123

Figure 23: Research sub-question 1 - Conceptual framework ............... 124

Figure 24: Modified framework based upon findings for sub-question $1 \ldots 125$

Figure 25: Research sub-question 2 - Conceptual framework ................. 127

Figure 26: Research sub-question 2 empirical findings ................... 129

Figure 27: Research sub-question 3 - Conceptual framework and findings 131 
Figure 28: Locations of slums (2010 survey) and displacement inducing projects (MRTS, BRTS, TOD, Riverfront and lakefront development) ....... 132 Figure 29: Slums to be displaced by projects (MRTS, BRTS, TOD, Riverfront

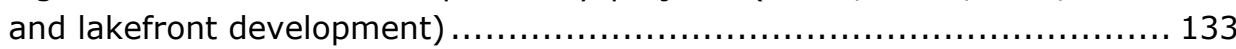
Figure 30: Slums eligible for compensatory shelter on eviction (1976 surveyed

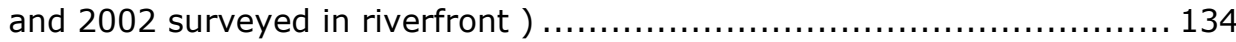

Figure 31: Emerging conceptual framework .............................. 136 Figure 32: Typology of transparency policies (adapted from Georgiadou et al.

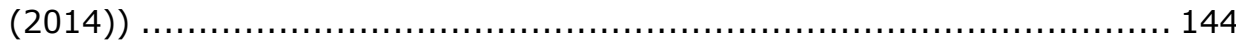

Figure 33: OGD platform of Government of India ........................ 147

Figure 34: GoG and AMC's commitment on enactment of Public Disclosure Law

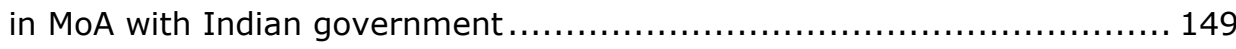




\section{List of tables}

Table 1: Gujarat and India real Gross Domestic Product (GDP) growth rates (\%per annum), 2004-2010........................................... 8

Table 2: Summary of policy and implementation of decentralisation and

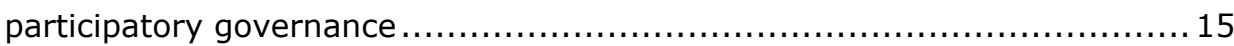
Table 3 Summary of policy and implementation of neoliberalisation and

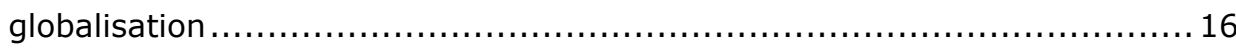
Table 4: Articles of Fundamental Rights and Directive Principles encompassing

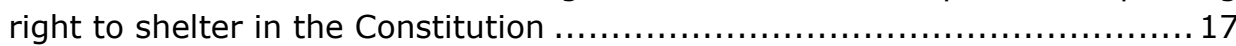
Table 5: Demographic growth rate of AMC and AUA 1981-2011 ............ 22

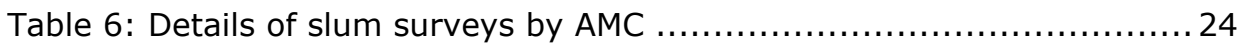
Table 7: Details of ward budget as percentage of total municipal budget in last

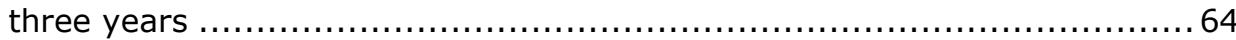
Table 8: Per capita ward budget of top 10 wards in terms of marginalised population composition ( SC and ST as \% of ward population) ..............65 Table 9: Individual discretionary annual budget of councillors from different parties spent on poor versus middle class neighbourhoods in 2013-14 ......68 Table 10: Budget for marginalised population from total city budget ( from

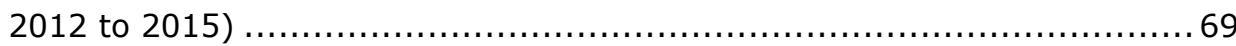

Table 11: Documents collected for petition on 1976 cut-off date .............. 75 Table 12: A priori understanding of positions of various actors on

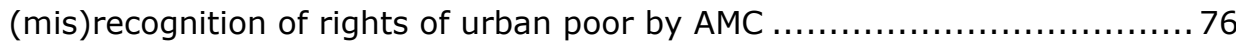
Table 13: Documents collected from concerned actors in case of petition on right to basic services ................................................... 77 Table 14: Summary of Actors' stance on the petition on shelter right and cut-

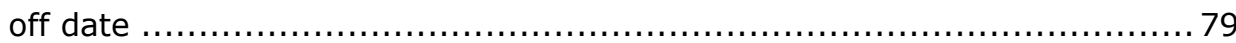
Table 15: Position and discursive devices of actors on (mis)recognition of

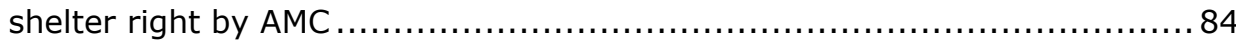
Table 16: Timeline and Evolution of the petition on right to basic services .. 87 Table 18: Projects that caused displacement ................................. 98 Table 19: Sample framework (from primary reconnaissance survey, June

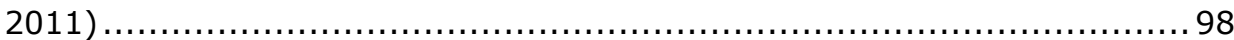

Table 20: Specific indicators employed in Ahmedabad, based on Cernea's

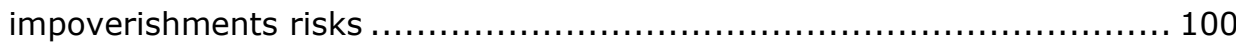

Table 20: Loss of employment and income days after displacement........ 105 Table 21: Increase in distance to work and travel to work expenditure after

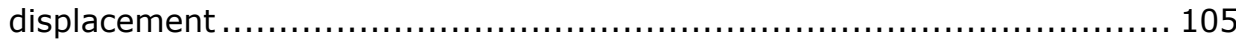
Table 22: Loss of shelter and associated losses for displacees on interim site

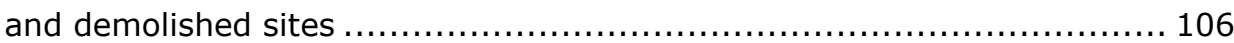
Table 23: Status of community facilities on BSUP sites (primary survey August

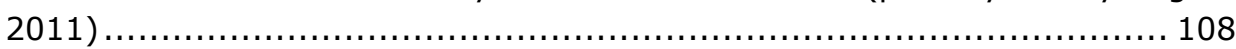

Table 24: School dropout and loss of school days after displacement ....... 108 
Table 25: Increase in distance to school and travel to school expenditure after

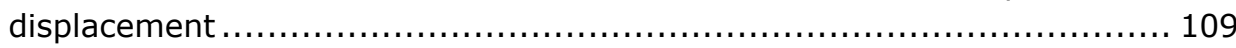

Table 26: Distance to municipal hospitals (in Km) ........................... 109

Table 27: Resettlement pattern of slum communities on various resettlement

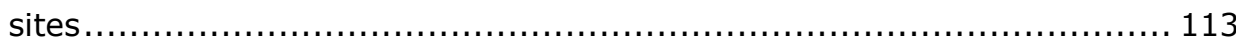

Table 28: Issue of Notice prior to demolition and resettlement.............. 115

Table 29: Awards for urban development projects for AMC (2002-2012) .. 121

Table 30: Assumptions of transparency policies (adapted from Fenster

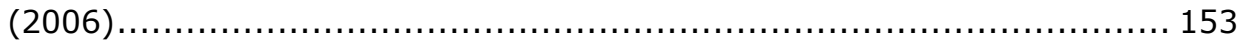

Table 31: Adapted from Fenster (2006) with additional reality

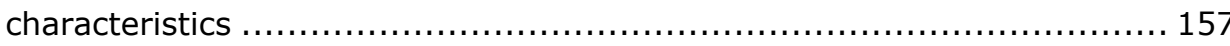




\section{List of abbreviations}

74 $4^{\text {th }}$ CAA 74th Constitutional Amendment Act, 1992

AMC Ahmedabad Municipal Corporation

AS Area Sabha

AJL Ahmedabad Janmarg Limited

BPL Below Poverty Line

BRTS Bus Rapid Transit System

BSUP Basic Services for Urban Poor

CAGR Compound Annual Growth Rate

CBO Community Based Organisation

CESCR UN Committee on Economic, Social and Cultural Rights

$\mathrm{CPL} \quad$ Community Participation Law

CSOs Civil Society Organizations

DIDR Development-Induced Displacement and Resettlement

EWS Economically Weaker Section

FSI Floor Space Index

FOI Law Freedom of Information Law

GDP Gross Domestic Product

GoG Government of Gujarat

GoI Government of India

HDI Human Development Index

ICESCR International Covenant on Economic, Social and Cultural Rights

ICMA International City Management Association

IRR Impoverishment Risks and Reconstruction framework

JNNURM Jawaharlal Nehru National Urban Renewal Mission

JSM Jan Sangharsh Manch

MEGA Metro-Link Express for Gandhinagar \& Ahmedabad Company Limited

MHUPA Ministry of Housing and Urban Poverty Alleviation

MoA Memorandum of Agreement

MoU Memorandum of Understanding

MoUD Ministry of Urban Development

MRTS Metro Rail Transit System

NOC No Objection Certificate

NGOs Non-Governmental Organisations

NDSAP National Data Sharing and Accessibility Policy

OGD Open Government Data

PIL Public Interest Litigation

PM Prime Minister

PDL Public Disclosure Law

RTI Right To Information

RAY Rajiv Awas Yojna

RWA Resident Welfare Association 


$\begin{array}{ll}\text { SC } & \text { Standing Committee } \\ \text { SCA } & \text { Special Civil Application } \\ \text { SDP } & \text { State Domestic Product } \\ \text { SDI } & \text { Shack/Slum Dwellers International } \\ \text { SIDA } & \text { Swedish International Development Agency } \\ \text { SLP } & \text { Special Leave Petition } \\ \text { SNAM } & \text { Sabarmati Nagarik Adhikar Manch } \\ \text { SNP } & \text { Slum Networking Program } \\ \text { SPV } & \text { Special Purpose Vehicle } \\ \text { SRFD } & \text { Sabarmati Riverfront Development } \\ \text { SRFDCL } & \text { Sabarmati Riverfront Development Corporation Limited } \\ \text { TOD } & \text { Transit Oriented Development Zone } \\ \text { UDHR } & \text { Universal Declaration of Human Rights } \\ \text { UD\&UHD } & \text { Urban Development and Urban Housing Department } \\ \text { ULBS } & \text { Urban Local Bodies } \\ \text { WC } & \text { Ward Committees }\end{array}$


Chapter 1

Understanding issues and the context 


\subsection{Introduction}

In 2009, before commencing my PhD, I was intrigued by the eviction of slum dwellers living in Ahmedabad's river bed to make space for the implementation of the flagship urban project and pet of the Chief Minister of the State of Gujarat, Narendra Modi, who is now the Prime Minister (PM) of India. The project was the Sabarmati Riverfront Development (SRFD) in Ahmedabad.

As an urban planning academic and practitioner, I was familiar with the high priority accorded to the project by the State of Gujarat and the local government of Ahmedabad but neither I nor the broader academic and planning community had access to the project details. While the master plan and details of implementation remained elusive, abstract posters with exciting visuals of a vibrant waterfront à la Shanghai's Pudong riverfront or Singapore's Clarke Quay were widely publicised by the state and local governments. The average middle class citizens, including my neighbours and friends, were excited about the project and filled with civic pride. The visuals suggested that middle class Gujarati citizens were looking forward to the "Shanghaification" of Ahmedabad, and to the advertised "hotels, restaurants, retail chains, parks, promenades that would be developed on the riverfront making it a world-class city". I decided to "enter" the field to learn more about the causes and consequences of evictions on the livelihoods of evictees.

My first visit was to one of the many demolished slum sites on the river bed. A discussion on the site with one of the community leaders revealed that while more than 10000 slum families (an approximate number as there was no consensus on the exact number) were supposed to be evicted, only those who were "eligible" would get compensatory shelter elsewhere. It was not clear to them what "eligibility" meant, who would be resettled, where and when. The local government had only given vague assurances of resettling all evictees elsewhere, but had not taken concrete actions or shared information on the project's resettlement policy. The councillors who were approached, showed sympathy but could not stop the evictions which by then had become frequent and involved large numbers of evictees each time. As there was no participatory platform available to negotiate its rights with the local government, leaders of the community evicted because of the riverfront project were forced to file a petition to the High Court with the help of civil activists and claim their right to shelter. My discussions with one of the community leaders revealed that a slum community from another part of Ahmedabad had also filed a petition to claim the right to basic services such as water supply and sewerage connection. Yet another community, anticipating eviction under other development projects, had filed a petition to claim the right to shelter and a revision of the cut-off date for compensatory shelter. It appeared to me that claim making through the judiciary was the only way 
available to slum dwellers to force the local government to negotiate their socio-economic rights.

The community leaders I had contacted led me to two of the many resettlement sites for evictees in the periphery of the city. Families evicted to make space for other prestigious and pet projects of the Chief Minister-the Kankaria Lakefront Development and the Bus Rapid Transit System (BRTS)-had been also resettled on these sites. Though the new dwellings were well-designed and well-built, many families appeared disoriented as they had lost their livelihoods and ties to their former social networks on these distant sites.

In the meantime, the lobby of Ahmedabad's Municipal Corporation (AMC) office featured large posters with visuals of a spectacular and vibrant waterfront, readied for the "Vibrant Gujarat Global Investors Summit" in 2009, a biennial event organised by the state government to provide a forum for national and global investors to interact with the government and Gujarat-based companies and attract investments. Previous Vibrant Summits had also framed Ahmedabad's riverfront, lakefront and BRTS projects as the gateway for attracting investment and profit opportunities in Gujarat and had been held on the reclaimed land on the riverfront I had visited. These summits were attended by global leaders and investors from many countries, international media reporters, and heads of leading financial institutions-all deliberating on investment opportunities in Gujarat and its cities and regions-and were widely publicised globally.

In my discussion with the deputy municipal commissioner I learned that the local government viewed slums as "an obstruction to these prestigious projects and to the remaking of Ahmedabad as a world-class city." SRFD and BRTS projects were implemented on "a fast track basis through Special Purpose Vehicles (Sabarmati Riverfront Development Corporation Limited and Ahmedabad Janmarg Limited respectively) to avoid the delays associated with municipal decision-making and democratic deliberations and the petitions by slum dwellers were derailing this fast track delivery." I quizzed him on who in local government, besides the councillors, slum dwellers usually approach to negotiate their rights, and whether the ward committees which are mandatory under the 74th Constitutional Amendment Act, 1992 (74 ${ }^{\text {th }}$ CAA) of India were in place. His response was "What rights?" According to him, encroachers have no legal rights, but they had been tolerated so far by a benevolent municipal corporation which had refrained from evicting them from a highly-priced land in a core city area. However, when this land was required for iconic global city projects aiming to attract global investments for development of commercial and luxurious spaces, to boost the quality of life of tax-paying and propertied middle class citizens and take the city ahead of other Indian cities, evictions ensued. He was silent on the mandatory ward committees and the presence of 
any participatory platforms through which evictees could negotiate their rights in regular governance processes.

\subsection{Emerging issues}

From these initial visits and interviews and coding of the field notes and interview transcripts, a few patterns and issues began to emerge.

\section{Status of decentralisation and participatory governance and its implications for the poor?}

Despite the mandate for decentralisation and participatory governance under the $74^{\text {th }}$ CAA, platforms through which slum dwellers could negotiate their socio-economic rights seemed to be absent. It was not clear whether the state government had ratified the $74^{\text {th }}$ CAA and, if it had ratified it, whether the local government had implemented it. The councillors did not appear to be responsive to the poor either. These initial observations led me to inquire the status of decentralisation and participatory governance in Gujarat and Ahmedabad and their consequences for the poor.

\section{Entrepreneurial local and state governments seeking global investments, and implications for the poor?}

The Government of Gujarat (GoG) and AMC appeared to be influenced by a global thinking that favoured a new system of urban governance and resource mobilisation through semi-autonomous, non-democratic bodies, which commercialised the commons such as river and lake fronts, and sought national and global investments for urban development projects in global investor summits hosted in the city. While the middle class appeared to not only support but also to aspire towards such projects, the slum dwellers seemed negatively affected. "Allowed" to live in this currently highly-valued land for generations, they were suddenly evicted as the land was required for more profitable uses while the policy on compensatory shelter was not clear. The socio-economic well-being of evictees considered "eligible" for relocation to other sites seemed to have been negatively affected. Was there a shift from a welfare city which took care of its poor to an entrepreneurial (neoliberal) city that functions on the market logic of profit making and efficiency?

These preliminary observations led me to inquire the neoliberalisation policies in governance in Gujarat and Ahmedabad and their consequences for slum dwellers. The claim making process in the court where the government would be forced to negotiate the rights with the poor seemed to offer a good opportunity to explore both the government's and the judiciary's stance on the socio-economic rights of the poor in the emerging economic scenario in the state and the city. 


\subsection{Empirical context}

The foregoing section suggests that the emerging issues around the poor were related to the specific implementation of the decentralisation, participation, neoliberalisation and constitutional frameworks at the State and city level as well as the judiciary's interpretation of socio-economic rights, especially of the poor, and AMC's stance on these rights. I discuss these frameworks in the macro settings of India and their implementation in the micro settings of the State of Gujarat and the city of Ahmedabad.

\subsubsection{Decentralisation and participatory governance framework in India and implementation in Gujarat and Ahmedabad}

The Government of India (GoI) mandated decentralisation and participatory governance first in 1992 through the $74^{\text {th }}$ CAA and further in 2005 through the Community Participation Law (CPL), under Jawaharlal Nehru National Urban Renewal Mission (JNNURM). Prior to 1992, citizen participation had been voluntary and mostly limited to projects, such as the Slum Networking Project, as well as other slum upgrade programs implemented in in Ahmedabad (Dutta, 2000). Participation occurred less frequently in the decision making stages than in the implementation and monitoring stages of projects (Ghosh and Mitra, 2008). Governments had no legal obligation to formalise citizen participation in routine governance processes such as annual budget formulation, planning and monitoring the implementation of neighbourhood infrastructure projects (Ghosh and Mitra, 2008). Decentralisation through the $74^{\text {th }}$ CAA involved the devolution of power, functions and resources from the state to local governments and from local government to new participatory spaces, called Ward Committees (WC), in cities with a population of more than 300,000 . WCs were supposed to allow elected councillors, administrative officers and citizens groups to deliberate together and allow citizens a platform to negotiate their needs. The Act left it to State governments to decide the composition, proximity to citizens, functions, powers and resources of WCs.

State governments took a long time to ratify the Act and set the processes in motion in their Urban Local Bodies (ULBs). By 2005 many but not all cities had created WCs, though with vast differences across cities in terms of the committees' composition, proximity to citizens, functions, powers and resources (deWit et al., 2008). As a result, the same political party which had passed the $74^{\text {th }}$ CAA in 1992, reinforced the Act through the enactment of the CPL in 2005 to accelerate decentralisation at the State and local levels.

The GoI proposed a model CPL for state governments to emulate. The model CPL's proclaimed objective was to "deepen democracy, facilitate efficiency and socio-economic growth and promote pro-poor initiatives" (Government of India, 2006d:2). It proposed a minimum of three tiers of decision making in a ULB-the city level, the Ward Committee, and Area Sabha (AS) with participatory spaces for citizens at the latter two levels. State governments 
had to either enact a separate CPL along the lines of the model CPL or make appropriate amendments to their existing municipal laws to clearly define composition, proximity criteria, functions, powers and funding sources of the two participatory tiers (Government of India, 2006d). The ULBs then had to implement these tiers as per the State's CPL statute. To ensure compliance by the State and local government, a tripartite Memorandum of Agreement (MoA) between national, state and local government had to be signed. Noncompliance with the agreed conditions in the MoA would lead to curtailment of the grants from the national government under JNNURM.

The WCs and ASs were to act as participatory platforms for neighbourhood governance, to deepen the participation of the citizens in urban transformation processes and enhance the responsiveness of the local government to their needs (Sivaramakrishnan, 2000). By 2010, both the $74^{\text {th }}$ CAA and the CPL were ratified and implemented to different degrees by state governments (deWit et al., 2008, Nainan and Baud, 2008, TERI, 2010, Ghosh and Mitra, 2008). However, research on the implementation of these initiatives in practice is limited to a few early-ratifier states, like West Bengal, Kerala, Maharashtra, Madhya Pradesh and Karnataka. Gujarat ratified the $74^{\text {th }}$ CAA in 1997 and implemented the decentralisation reforms by devolution of power, functions and resources from the State to the local government. But WCs were institutionalised only in 2007 and ASs only in 2012 when they were made a pre-requisite for availing grants from GoI. For me, this was an indication of the priority accorded to implementation of participatory governance by GoG that I was seeking to inquire.

Nevertheless, the GoG policy on WCs and ASs was not publicly available and criteria used for their composition, proximity, functions, powers and funding sources were not known. My initial field visits indicated that slum dwellers were not aware of either of the participatory platforms (WC and AS). The practice of decentralised and participatory governance in cities of Gujarat State, including Ahmedabad, had not yet been researched. What opportunities do these spaces offer to different social groups to deliberate on ward development policies and negotiate their rights? Are all social groups equally represented? Whose interests are served? I seek to answer these questions in chapter 3 of the thesis.

As in other cities, citizen participation had been practiced in Ahmedabad but was limited to specific projects. For instance, under JNNURM guidelines, City Development Plans identifying development priorities mandated stakeholder consultations, in order to reach consensus with the citizens, including the poor, in project identification, prioritisation, and willingness and ability to pay for the envisioned projects. Such "consultations" were argued to be tokenistic and limited in scope and coverage across India (Mahadevia, 2011). The inquiry on 
experiences of the poor in Ahmedabad in these "stakeholder consultations" is addressed in chapter 5 of the thesis.

\subsubsection{Economic liberalisation and globalisation policy in India}

The entrepreneurialism I observed in the local government in Ahmedabad has its roots in the economic liberalisation and globalisation policy initiated by GoI in 1991 through structural economic changes. The objective was to make the economy more market-oriented and expand the role of private and foreign investments in various sectors. Changes included reduction in import tariffs, deregulation of markets, reduction of taxes, greater incentives to foreign investments and withdrawal of the state from hitherto obligatory government functions, such as construction and maintenance of roads and highways, and power generation and distribution. These changes heralded a shift from a welfare to a neoliberal state; from redistributive policies that address inequalities to a market logic of efficiency, profit maximisation and growth (Chatterjee, 2014, Kohli, 2006). To repeat the metaphor used by The Economist (India Survey, May 4, 1991) "the animal urges of Indian entrepreneurs were "uncaged", capital accumulation in and efficiency of the economy improved, propelling India into the ranks of the world's fastest growers" (Kohli, 2006:1251). The overall direction of liberalisation has since remained unchanged, irrespective of the ruling party, though a variety of politically difficult issues such as liberalising labour laws and reducing agricultural subsidies remain unsolved. Proponents have credited economic liberalisation for the comparative high economic growth recorded in the 1990s and 2000s, whereas opponents have blamed it for increased poverty, inequality and economic degradation across India (Hirway et al., 2014, Kannan, 2015).

I was specifically interested in the impact of economic liberalisation on the urban arena. Scholars have shown that it has been accompanied by the rise of the new middle class in India, marked by changing consumption practices and lifestyles (Ghertner, 2008, Fernandes, 2004), and the spatial reconfiguration of class inequalities (Desai, 2012a). The rise of the urban middle class has initiated a "politics of forgetting" social groups, such as the slum dwellers, that are marginalised by the liberalisation policies (Ghertner, 2008). This resonates with my initial field observations on the urban projects, which had displaced the poor but were supported and desired by sections of the middle class in Ahmedabad.

\subsubsection{Neoliberalisation and globalisation in Gujarat}

The economic policies of GoG are embedded in the policies of GoI but also respond to Gujarat's own cultural milieu, nature of civil society and politics (Shah, 2014). Gujarat's neoliberal growth since the 1990s is higher than the Indian average (Table 1). Leading economists (Bhagwati and Panagariya, 
2012, Debroy, 2012) have projected it as a model for a neoliberal India and for other Indian States on the grounds that it has delivered rapid and inclusive economic growth along with social development. As one of the fastest growing economies of India with average economic growth rate of 10 per cent per annum (2004-2010), Gujarat has surpassed the national average of 8.4 per cent per annum for this period (Table 1 ).

Table 1: Gujarat and India real Gross Domestic Product (GDP) growth rates (\%per annum), 2004-2010

\begin{tabular}{|l|c|c|}
\hline Fiscal year & India & Gujarat state \\
\hline $2004-05$ & 7.5 & 8.9 \\
\hline $2005-06$ & 9.5 & 15.0 \\
\hline $2006-07$ & 9.6 & 8.4 \\
\hline $2007-08$ & 9.3 & 11.0 \\
\hline $2008-09$ & 6.8 & 7.0 \\
\hline $2009-10$ & 8.0 & 10.2 \\
\hline Avg.2004-05 to 2009-10 & 8.4 & 10.1 \\
\hline
\end{tabular}

Source: Planning Commission, Government of India, http://planningcommission.gov.in

Countering this perspective, other scholars have shown that economic reforms in Gujarat have not translated into inclusive growth and improved human development (Hirway et al., 2014, Shah, 2014, Hensman, 2014) . In 2005, Gujarat ranked only $6^{\text {th }}$ in the Human Development Index (HDI) among the 15 largest Indian states (Hirway and Mahadevia 2005). These scholars suggest that although India's neoliberal model itself is not inclusive, the case of Gujarat is more problematic because its main priority is to increase the State Domestic Product (SDP) and to become "the fastest growing economy not only in India but in the world", "the most attractive destination for investments not only in India but also in the world" and "to remain in the forefront of competition and technology innovation in the world to attract large scale investments from India and world" (Government of Gujarat, 2009, Government of Gujarat, 2003). However, these pursuits have made redistribution to excluded social groups difficult and increased inequalities in the State. To woo private capitalists, the State government has supported crony capitalism by providing huge subsidies and concessions along with easy access to credit, land and infrastructure to private capitalists. This has led to a capital-intensive (thanks to cheap capital) and not to the labour-intensive growth, usually associated with higher employment levels. As a result, growth in Gujarat is often termed as "jobless growth". Further, huge subsidies, grants and concessions given to the private sector leave relatively less for social sectors and have made the redistribution to excluded groups difficult (Hensman, 2014). Key infrastructure such as roads and highways, power generation and ports have been outsourced to private capital. Thus, "the government has abdicated all decision making powers, as well as functional and financial control over such projects. Nowhere else in the country has this abdication of responsibility been so total, nowhere else has 
the state given over the economy so entirely to the corporates and private investors" (Nigam, 2013).

GoG's largesse to corporations can be illustrated by the subsidies offered to Tata for its Nano plant and other projects. Against an investment of INR 29000 million, Tata received a loan of INR 95700 million at $0.1 \%$ interest, to be paid back on a monthly basis after 20 years, in addition to land at much below market rates, and stamp duty, registration charges and electricity paid for by the state. Tax breaks mean that the people of Gujarat will not be getting any of this money back in the near future (Hensman, 2014).

In contrast to the rise of private sector, the contribution of civil society actors to governance has decreased substantially, power remains centralised and shared with elite capitalists, dissent to the powerful is discouraged, public information is not shared, the middle class has emerged as the favoured electorate and the underprivileged remain marginalised. The so-called "good" governance is primarily for the propertied and the middle class in Gujarat (Shah, 2014: 532, TOI, 2011). Those who campaign against corruption in the state by evoking the Right To Information (RTI) Act 2005 have not fared well. With only $5 \%$ of India's population, $22 \%$ of the murders and $20 \%$ of the assaults on RTI activists in recent years have occurred in the State of Gujarat, which has only two RTI Commissioners (for 60 million population) compared to eight in Maharashtra (for 112 million) and nine in Tamil Nadu (for 72 million) (Pandey, 2013, Shah, 2014).

The private investment driven growth is promoted by high-impact sloganeering campaigns. One of the key slogans of the Chief Minister of the State, which he would later use as the PM of India, has been "Minimum government and Maximum governance" and "Government has no business to do business." For an average middle class Gujarati citizen this holds the promise of a businessfriendly State with minimum regulatory interference. But for a marginalized citizen the slogan holds the threat of a "withdrawing state" and of "selfresponsibilisation".

In addition to sloganeering, mega branding events are organised to encourage investor-driven growth. The "Vibrant Gujarat Global Investor Summit" is one such biennial event organised by GoG since 2003 to provide a forum for national and global investors to interact with the government and Gujaratbased companies for investment opportunities. These summits have made global news as they are attended by global leaders and investors, international media reporters, heads of international financial institutions, top industrialists of India and chief ministers of other states of India-all deliberating on investment opportunities in Gujarat and its cities and regions. The Vibrant Summits typically conclude with a statement by GoG of the total capital 
investment pledged by investors through Memorandum of Understanding (MoUs) in the summit. Critics argue that only a fraction of pledged investments has translated into actual investments whereas others have argued that the summits have made Gujarat the top state in national and global investments (ASSOCHAM, 2012).

The 2015 Summit was hosted by Modi as the PM of India. Global leaders, including United Nation's (UN) Secretary-General Ban Ki-moon, World Bank President-Jim Yong Kim, US Secretary of State John Kerry attended, praised the 'governance model of Gujarat' set in motion by the PM Modi as the Chief Minister of the State, and pledged investments in Gujarat and India. Excerpts of speeches by the global dignitaries reveal a myopic view of development in Gujarat. Inequalities in the model did not appear to be an issue:

"Gujarat is a prime example of how sustainable energy and climate action are different aspects of the same issue, and connect to economic growth, increased social equity and a healthier environment" by UN Secretary General (UN, 2015)and "For investors, entrepreneurs and CEOs thinking of doing business in Gujarat and the country as a whole, there's much reason for optimism [...] Prime Minister Modi and his government are quickly putting in place the building blocks for even more rapid growth, streamlining the national regulatory structure, using public funds more efficiently, and promoting social inclusion" by the World Bank President (World Bank, 2015). In the 2015 Summit, global and national investors pledged a record of INR 25 trillion (USD 0.35 trillion). However, in response to criticisms by the media and civil society, the GoG changed its tagline in the posters from "Global Investor" in 2003 to "Development for All" in 2015, (Figure 1). Nevertheless the agenda remained more or less the same.

My specific interest was to inquire what this specific form of neoliberalisation meant for Ahmedabad, Gujarat's largest city, which is both the gateway for global investments and a model for other big cities in the State (Desai, 2012a).
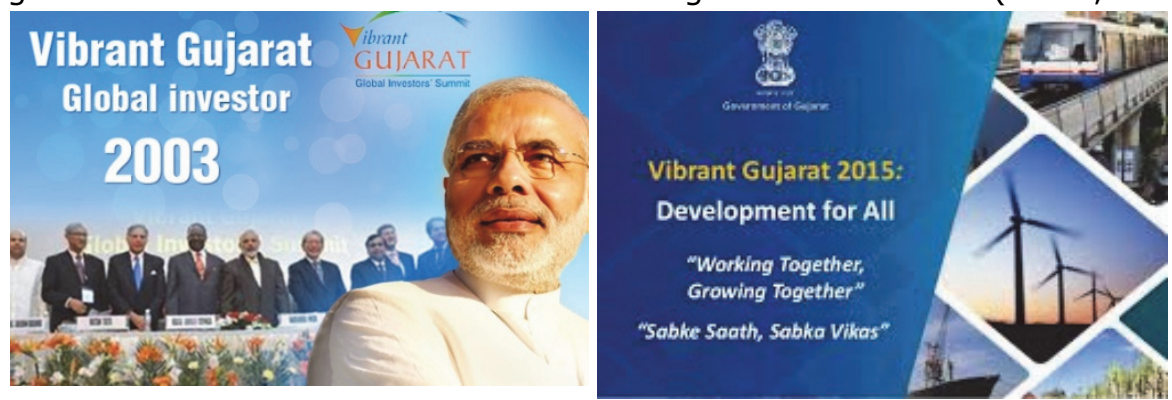

Figure 1: Shift in tagline of Vibrant Gujarat summit from 2003 to 2015 


\subsubsection{Neoliberal turn in governance in Ahmedabad}

The AMC's neoliberal turn consisted of five shifts: The first shift was the introduction of a market logic of functioning underpinned by principles of efficiency and profit maximisation for a few obligatory and discretionary functions of AMC, without entering into institutionalised partnerships with private capitalists. As per the Gujarat Municipal Corporation Act of 1949, obligatory functions are mandatory, while discretionary functions are optional for a municipal corporation. Under this shift, obligatory functions, e.g. water supply, sewerage and solid waste management, had to be "self-financing" and had to cut losses through various mechanisms. Discretionary functions, e.g. health care, were also made "self-financing". The implications of this shift for the poor are discussed in chapter 4 of the thesis.

The second shift was the privatisation of some obligatory and discretionary functions by entering into institutionalised partnership with private companies, under various conditions of partnership. This shift affected obligatory functions such as electricity generation, transmission and distribution (transferred to Torrent Power Limited), operation and maintenance of parks (transferred to Amul or Gujarat Cooperative Milk Marketing Federation Ltd) and solid waste treatment (transferred to six different companies) as well as new discretionary functions such as the piped cooking gas network (transferred to Adani Gas Limited) and Compressed Natural Gas (CNG) for transportation (transferred to Adani Gas Limited). Privatisation of electricity meant reduction in the subsidies both for accessing a connection and in consumption rates. Privatisation of gas meant that the poor could not afford access to a gas connection and had to resort to other options.

The third shift was the formation of semi-autonomous bodies (so-called Special Purpose Vehicles), which are nested within local government but outside the arena of political deliberation, for efficient delivery of high priority, city branding projects. The SRFD and BRTS were two such projects, implemented through semi-autonomous bodies named Sabarmati Riverfront Development Corporation Limited (SRFDCL) and Ahmedabad Janmarg Limited (AJL) respectively. Both projects were high priority for the State and local governments, aiming to brand Ahmedabad as a "world- class" city and hence placed on fast-track development. They were given centre-stage in the Vibrant Summits to reflect the state of affairs in the State and act as gateways for investments in the State. Since these bodies were semi-autonomous, the master plans and implementation details were not publicly disclosed, an otherwise mandatory requirement for city master plans under the Gujarat Town Planning and Urban Development Act, 1976. Slum dwellers located within the influence area of the riverfront project and right-of-way of BRTS project were evicted without consultations with slum dwellers "eligible" for 
resettlement, while the details of resettlement and rehabilitation were not publicly disclosed.

The SRFD project was essentially an appropriation of commons along the riverbed, about $100 \mathrm{~m}$ wide and along $10 \mathrm{~km}$ of river length on both river sides. The reclaimed land was to be developed as a commercial corridor with enclaves of boulevards, water parks, retail chains, hotels and multiplexes through a master plan whose details were not disclosed. Private capital was sought to invest in land parcels in the reclaimed area and project development cost was to be met from sale of these parcels. Though this was a "selffinancing" project, it was decided that the "social cost" of rehabilitation of the displaced slum dwellers would not be borne by the project cost but rather offloaded to the subsidised public housing being constructed under JNNURM's Basic Services for Urban Poor (BSUP) scheme (Concerned Citizens of Ahmedabad, 2010). The consequences of this transfer of social responsibility for evictions are addressed in chapter 5 of this thesis.

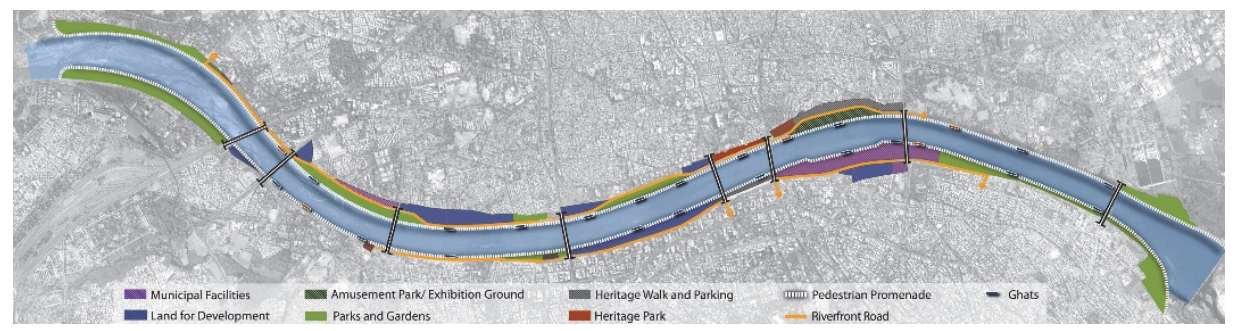

Figure 2: Master Plan of riverfront development project

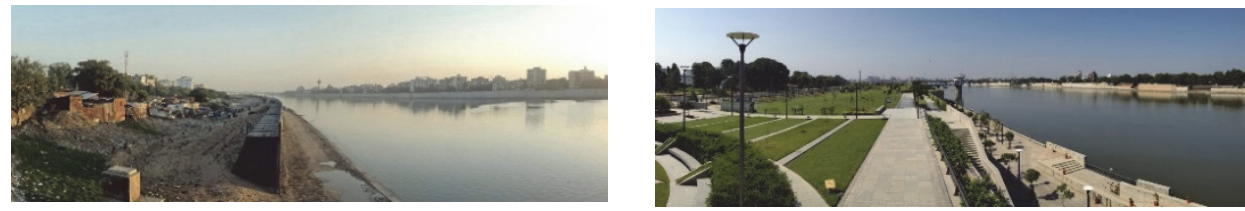

Figure 3: Redeveloped section on riverfront after eviction of slums
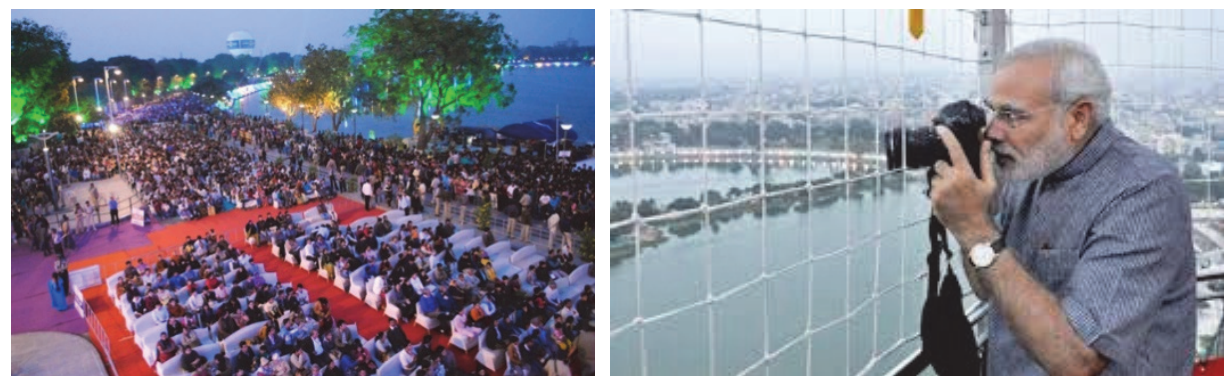

Figure 4: Vibrant Summit celebrations in the redeveloped Kankaria lakefront 
The fourth shift was the initiation of beautification and infrastructure projects to improve the city's image and attract new businesses. Besides the riverfront project other projects such as Kankaria lake front development, Walled city revitalisation, Gandhi ashram precinct redevelopment and Vastrapur lake front development were framed as urban renewal projects. Here also the rationale was one of appropriation of commons for redevelopment as a mix of commercial and recreational activities which would be handed over to private capital, except that these projects were not mooted through semi-autonomous bodies as in the earlier case. It was commonly believed that under the Kankaria lakefront project close to 500 households were in different stages of displacement. The consequences of evictions for the poor is addressed in chapter 5 of the thesis.
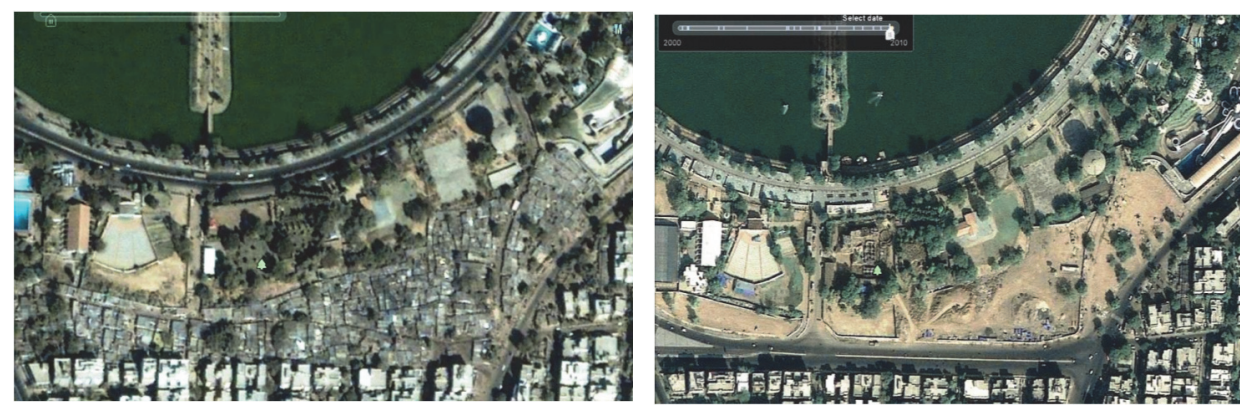

Figure 5: Slum displacement under Kankaria lakefront development

The fifth shift involved specific ways of regulating land use in the town planning schemes through which neighbourhood planning is undertaken in Gujarat. These involved an increase of profitable land uses by commercialising the commons and converting land parcels, previously reserved for housing the poor, to commercial use. This meant that land sites available for construction of housing for the Economically Weaker Section (EWS) would be reduced. A shift to commodification of the commons for capital accumulation was underway.

In general, an ideological shift towards functioning with market logic of efficiency and discipline within the executive in local government, and towards middle class as a favoured electorate within political representatives had begun (Shah, 2014, Mahadevia, 2002). For the propertied middle class citizen, the shifts of AMC towards neoliberal practices signify a "world-class" city brand, higher competitiveness for new businesses vis à vis other cities, appreciated property values, better service delivery albeit at higher cost, and better quality of life. Thus, it is not surprising that these shifts have the support of these citizens, who participate and celebrate in the Vibrant Summits with enthusiasm. 
For the poor these practices signify commodification of their socio-economic rights such as right to basic services if deemed as eligible users, disavowal of their right to shelter as land in the core area of the city would be appropriated for "profitable uses", compensatory shelter on eviction for limited households based on eligibility criteria, lack of participatory spaces from where they could negotiate their rights with the local governments, taking judicial recourse in face of non-responsive local government and resettlement of a few on unknown sites with uncertain consequences. I seek to answer these inquiries in chapters 3 to 5 of the thesis.

\subsubsection{Indian Constitution and the judiciary's stance on shelter rights}

In the neoliberal context in India, the judiciary plays an increasingly prominent role in urban governance related to poor, not only as an arbiter of justice but also as a parallel administrative and executive body (Bhan, 2009, Dupont \& Ramanathan, 2008, Ghertner, 2008). To understand the current stance of the higher courts in India-the Supreme Court of India and the High Courts of the Indian States-on various rights of the poor it is important to first understand how human rights are enshrined in the Constitution of India.

Citizens' civil and political rights are enshrined as fundamental rights in Part III of the Constitution, whereas socio-economic rights are enshrined as directive principles or policy aspirations for Indian States in Part IV and hence are implied and not fundamental rights. Thus, right to shelter, basic services and livelihood as socio-economic rights are not fundamental rights but are implied in various articles of directive principles. However, the judiciary had often interpreted the right to shelter and basic services in some articles of fundamental rights in its years of activism (Rajagopal, 2007), as explained further and shown in Table 4. 
Table 2: Summary of policy and implementation of decentralisation and participatory governance

\begin{tabular}{|c|c|c|c|}
\hline Process & Policy enactment in India & $\begin{array}{l}\text { Implementation by } \\
\text { Government of } \\
\text { Gujarat (GoG) }\end{array}$ & $\begin{array}{l}\text { Implementation } \\
\text { by Ahmedabad } \\
\text { Municipal } \\
\text { Corporation } \\
\text { (AMC) }\end{array}$ \\
\hline \multirow{5}{*}{$\begin{array}{l}\text { Decentralisation } \\
\text { and } \\
\text { Participatory } \\
\text { governance }\end{array}$} & $\begin{array}{l}\text { 74th Constitutional } \\
\text { Amendment Act (74th } \\
\text { CAA), } 1992\end{array}$ & $\begin{array}{l}\text { (74th CAA ratified in } \\
1997\end{array}$ & \\
\hline & $\begin{array}{l}\text { Decentralisation mandated } \\
\text { through devolution of power, } \\
\text { function and resources from } \\
\text { State to local government }\end{array}$ & Implemented & Implemented \\
\hline & $\begin{array}{l}\text { Participatory governance } \\
\text { mandated by devolution of } \\
\text { power, functions and } \\
\text { resources to Ward } \\
\text { Committees (WC) as } \\
\text { participatory spaces. State } \\
\text { governments allowed to } \\
\text { frame own rules for WC } \\
\text { criteria. }\end{array}$ & Not implemented & Not implemented \\
\hline & $\begin{array}{l}\text { Model Community } \\
\text { Participation law (CPL), } \\
2005\end{array}$ & & \\
\hline & $\begin{array}{l}\text { Two tiers of participatory } \\
\text { spaces: mandated Ward } \\
\text { Committees and Area Sabhas } \\
\text { at lower level, as state reform } \\
\text { for getting funds from GoI. } \\
\text { State governments allowed to } \\
\text { frame own rules for criteria }\end{array}$ & $\begin{array}{l}\text { Rules for Ward } \\
\text { Committees enacted in } \\
\text { 2007, for Area Sabhas } \\
\text { in 2012, as made a } \\
\text { prerequisite for availing } \\
\text { grants from GoI. }\end{array}$ & $\begin{array}{l}\text { To be researched. } \\
\text { Discussed in } \\
\text { chapter } 3\end{array}$ \\
\hline
\end{tabular}


Table 3 Summary of policy and implementation of neoliberalisation and globalisation

\begin{tabular}{|c|c|c|c|}
\hline Process & $\begin{array}{l}\text { Policy enactment in } \\
\text { India }\end{array}$ & $\begin{array}{l}\text { Implementation by Gujarat } \\
\text { Government }\end{array}$ & Implementation by AMC \\
\hline \multirow{3}{*}{$\begin{array}{l}\text { Neoliberali } \\
\text { sation and } \\
\text { Globalisati } \\
\text { on }\end{array}$} & $\begin{array}{l}\text { Structural Economic } \\
\text { changes in } 1991\end{array}$ & $\begin{array}{l}\text { Structural changes in } \\
\text { policies mid 1990s }\end{array}$ & Initiated in mid 1990s \\
\hline & $\begin{array}{l}\text { Shift from } \\
\text { redistribution to } \\
\text { competitiveness for } \\
\text { capital through } \\
\text { reduction in import } \\
\text { tariffs, deregulation of } \\
\text { the markets, } \\
\text { reduction of taxes, } \\
\text { greater incentives to } \\
\text { foreign investments } \\
\text { and withdrawal of the } \\
\text { state from obligatory } \\
\text { functions }\end{array}$ & $\begin{array}{l}\text { Shift from redistribution to } \\
\text { competitiveness, tax } \\
\text { subsidies, concessions, easy } \\
\text { access to credit, land and } \\
\text { infrastructure. Privatisation of } \\
\text { roads, rail, ports and power. } \\
\text { Vibrant Gujarat Global } \\
\text { Investors Summit to attract } \\
\text { global capital. Representative } \\
\text { slogan : Minimum } \\
\text { Government, Maximum } \\
\text { Governance }\end{array}$ & $\begin{array}{l}\text { 1) turn to market logic in few } \\
\text { functions without } \\
\text { institutionalised partnership } \\
\text { with private capital, } \\
\text { 2) privatisation of few } \\
\text { functions, } \\
\text { 3)formation of semi- } \\
\text { autonomous bodies, outside } \\
\text { political deliberation for } \\
\text { efficient delivery of high } \\
\text { priority, city branding projects } \\
\text { 4) initiation of beautification } \\
\text { projects to improve the city's } \\
\text { image and attract new } \\
\text { businesses } \\
5 \text { ) conversion of commons } \\
\text { and the land parcels reserved } \\
\text { for housing the poor to } \\
\text { profitable uses. } \\
\text { Commodification of Commons }\end{array}$ \\
\hline & $\begin{array}{l}\text { Challenges: increased } \\
\text { poverty, inequality } \\
\text { and economic } \\
\text { degradation across } \\
\text { India, rise of the new } \\
\text { middle class and } \\
\text { "politics of forgetting" } \\
\text { marginalised social } \\
\text { groups }\end{array}$ & $\begin{array}{l}\text { Challenges: Crony capitalism, } \\
\text { capture of governance by } \\
\text { crony capitalists, power } \\
\text { centralised, dissent to power } \\
\text { discouraged, public } \\
\text { information not shared,middle } \\
\text { class as the favoured } \\
\text { electorate, underprivileged } \\
\text { remain marginalised }\end{array}$ & $\begin{array}{l}\text { Challenges: Propertied } \\
\text { citizens support and aspire } \\
\text { the shifts, for unpropertied } \\
\text { citizens the shifts imply } \\
\text { evictions and uncertain } \\
\text { consequences that need to be } \\
\text { researched. Discussed I } \\
\text { chapter } 4 \text { and } 5 \text {. }\end{array}$ \\
\hline
\end{tabular}

The judiciary has a mixed record towards human rights. Whereas it has largely affirmed civil and political rights, its post-independence response towards socio-economic rights, including right to shelter, basic services and livelihoods, has been mixed. 
Table 4: Articles of Fundamental Rights and Directive Principles encompassing right to shelter in the Constitution

\begin{tabular}{|c|c|}
\hline \multicolumn{2}{|c|}{ Articles in Part III, Fundamental Rights (enforceable by law) } \\
\hline Article 21 & $\begin{array}{l}\text { The right to protection of life and personal liberty except } \\
\text { according to procedure established by law. }\end{array}$ \\
\hline Article 14 & $\begin{array}{l}\text { The right of every citizen to be treated equally before } \\
\text { the law or be given protection of the laws within the } \\
\text { territory of India. }\end{array}$ \\
\hline Article 15 (1) & $\begin{array}{l}\text { The right of every citizen to be protected against any } \\
\text { discrimination on grounds of sex, religion, race, caste } \\
\text { or place of birth. }\end{array}$ \\
\hline Article $19(1)(d)$ & $\begin{array}{l}\text { The right of every citizen to move freely throughout the } \\
\text { territory of India. }\end{array}$ \\
\hline Article 19 (1) (e) & $\begin{array}{l}\text { The right of every citizen to reside and settle in any part } \\
\text { of the territory of India. }\end{array}$ \\
\hline Article 19 (1) (g) & $\begin{array}{l}\text { The right of every citizen to practice any profession, or } \\
\text { to carry on any occupation, trade or business. }\end{array}$ \\
\hline \multicolumn{2}{|c|}{$\begin{array}{l}\text { Articles in Part IV, Directive Principles (principles for policy } \\
\text { formulation within each State) }\end{array}$} \\
\hline Article 39 (1) & $\begin{array}{l}\text { State policy to be directed to securing for both men and } \\
\text { women equally the right to an adequate means of } \\
\text { livelihood. }\end{array}$ \\
\hline Article 42 & $\begin{array}{l}\text { Provisions to be made by the State for securing just and } \\
\text { humane conditions of work and for maternity relief. }\end{array}$ \\
\hline Article 47 & $\begin{array}{l}\text { Duty of the State to raise the level of nutrition and the } \\
\text { standard of living and to improve public health. }\end{array}$ \\
\hline
\end{tabular}

Source: HRLN, 2014

After the national emergency (1975-1977), during which the parliament had substantially curbed judiciary, constitutional powers and civil liberties, the judiciary was consecrated as the preferred branch of governance. In the face of a failing state apparatus that proved incapable to carry out its mandate under the law and the Constitution (Rajagopal, 2007), the Supreme Court began to adjudicate socio-economic rights enshrined in directive principles in part IV by interpreting them in articles of fundamental rights in part III and thus enforcing them. Thus began an era of "judicial activism" or "judicial governance" (Rajagopal, 2007) in which the Supreme Court began to affirm socio-economic rights, including the shelter rights of urban poor which had been hitherto dismissed through legalistic interpretations.

For instance, in the landmark case of Olga Tellis Vs Bombay Municipal Corporation (1985) the Supreme Court held that "the right to livelihood is an 
important facet of the right to life" and that "the eviction [of slum dwellers] will lead to deprivation of their livelihood and consequently to the deprivation of life." The Court showed sympathy by mandating resettlement of slum dwellers. It did not rule that they actually had a right to shelter but that an eviction without notice and compensatory shelter would be an arbitrary violation of their right to livelihood which it interpreted as a part of right to life and liberty under article 21 of fundamental rights. Thus the court cautiously affirmed a right to a process but not a remedy for the structural violation itself. Nevertheless it marked the beginning of a "cautiously sympathetic" Court which read the right to compensatory shelter on eviction under "right to life and personal liberty" under article 21 and the right to basic services such as water, sanitation, health and education facilities under the right to shelter. Since then, all cases of eviction of slum dwellers or denial of basic services are petitioned on the grounds of violation of fundamental right in article 21 (Bhan, 2009, Rajagopal, 2007, Ramanathan, 2005).

In another landmark case in 1990, of Shantistar Builders vs. Naryan Khimalal Totome and others, the Court affirmed that "the right to life would take within its sweep the right to food, the right to clothing, the right to decent environment and a reasonable accommodation to live in. The difference between the need of an animal and a human being for shelter has to be kept in view. For the animal it is the bare protection of the body, for a human being it has to be a suitable accommodation, which would allow him to grow in every aspect - physical, mental and intellectual." In the case of U.P Avas Evam Vikas Parishad vs. Friends Cooperative Housing Society Ltd. the Court explicitly upheld the right to shelter as a fundamental right stating that "the right to shelter is a fundamental right which springs from the right to residence under Article 19 (1)(e) and the right to life under Article 21."

The Supreme Court often relied on international law to uphold the right to compensatory shelter, because it had ratified both international treaties on human rights-International Covenant on Economic, Social and Cultural Rights (ICESCR) of 1966 and International Covenant on Civil and Political Rights 1966 in 1979. The right to shelter is upheld in article 11.1 of ICESCR (1966) which states that "the States Parties to the present Covenant recognize the right of everyone to an adequate standard of living for himself and his family, including adequate food, clothing and housing, and to the continuous improvement of living conditions. The States Parties will take appropriate steps to ensure the realization of this right, recognizing to this effect the essential importance of international cooperation based on free consent." By ratifying these treaties, GoI is legally bound by their provisions including the obligation to implement them in their entirety. Ratification creates a commitment of GoI to report regularly to the UN Committee on Economic, Social and Cultural Rights (CESCR) (HRLN, 2006), the monitoring agency for the treaty. 
Before the neoliberal turn, the Supreme Court of India had often read ICESCR in domestic cases of shelter rights such as in the case of Ahmedabad Municipal Corporation vs. Nawab Khan Gulab Khan. In upholding the right to compensatory shelter for evicted slum dwellers, it stated that the "right to life has been assured as a basic human right under Article 21 of the Constitution of India. Article 25(1) of the Universal Declaration of Human Rights declares that everyone has the right to a standard of living adequate for the health and well-being of himself and his family; it includes food, clothing, housing, medical care and necessary social services. Article 11(1) of the International Covenant on Economic, Social and Cultural Rights lays down that State parties to the Covenant recognize that everyone has the right to standard of living for himself and his family including food, clothing, and housing and to the continuous improvement of living condition." The Supreme Court has often upheld rights to basic services for slum dwellers as in the Ratlam Municipal Council vs. Vardichan case in 1980 where it clarified that municipal authorities and not slum dwellers are responsible for nuisance arising from slums with inadequate municipal services by stating that "providing drainage systems (to slums) [...] cannot be evaded if the municipality is to justify its existence."

Till the late 1980s the Supreme Court's cautiously sympathetic stance towards the shelter rights of the poor was well in consonance with the Indian State's welfare oriented development paradigm. However the Supreme Court's propoor tone suddenly changed in the late 1990s and began to share the biases of the executive government and its ideologies of development and economic growth (Rajagopal, 2007). It was loath to affirm rights which would openly contradict the Indian State's vision of development. The Supreme Court conformed with the "overall logic of the state" (Rajagopal, 2007: 5), while local governments and the rising middle class in cities such as New Delhi and Mumbai began to frame slums as "economically unviable" and "environmentally harmful" and often made petitions for their eviction on the grounds of slums being "against public interest" and a "public nuisance" using various environmental laws (Ghertner, 2008; Rajagopal, 2007; Ramanathan, 2006). The Supreme Court and some High Courts have begun to perpetuate this bias through anti-poor judgments that reject the socio-economic rights of slum dwellers and deem them "illegal".

In the landmark case of Almitra Patel vs. the Union of India case in 2000 the Supreme Court began to frame slum dwellers as usurpers, encroachers and criminals by stating that "large area of public land, in this way, are usurped for private use free of cost" by slum dwellers and that "the promise of free land, at the taxpayer's cost, in place of a jhuggi (slum), is a proposal which attracts more land-grabbers." The Court began to view post-eviction compensatory shelter, which till then had become mandatory in jurisprudence, as a matter of injustice by stating that "rewarding an encroacher on public land with an 
alternative free site is like giving a reward to a pickpocket for stealing. "Instead of slum cleaning, slum clearing became a priority with the Court stating that "instead of slum clearance there is slum creation in Delhi... What the slum clearance department has to show, however, does not seem to be visible. It is the garbage and solid waste generated by these slums which require to be dealt with most expeditiously and on the basis of priority." The Almitra Patel case judgment activated a discursive shift regarding slums and slum dwellers from the previous case laws (Ghertner, 2008). Now slums began to be equated with public nuisance and the slum dwellers as encroachers and criminals and their compensatory shelter came to be considered as a matter of injustice.

The very citizenship of the urban poor came to be questioned when in case of Okhla Factory Owners vs. GNATCD in 2002 the Court distinguished the poor as "those who have scant respect for law and unauthorisedly squat on public land" from the propertied people who were "citizens who have paid for the land." Thus began the jurisprudence which viewed the "public" or "citizenry" as those who owned property and viewed those without property as excluded from this category. The defence of private property became a matter of public interest. Ghertner (2008) terms this the "juridical embourgeoisement" of cities, a privatization of the definition of public life and interest.

Deconstructing orders of the Supreme Court and high courts of few states in petitions of the poor since the neoliberal turn, scholars (Ramanathan, 2006, Dupont and Ramanathan, 2008, Ghertner, 2008, Baviskar, 2003) that the judiciary has in fact significantly contributed to evolving jurisprudence of "illegality" of slums and shelter rights of urban poor in India. Ramanathan reiterates Rajagopal's (2007) postulation on the shift in stance of judiciary to align with the development ideology of the state by stating that "the constitutionality that ensured every citizen the fundamental rights of livelihood, housing and shelter has now been revised, reinvented and supplanted by a legality that sees the urban poor as encroachers and a threat to civic existence"(2006 : 93). However, it needs to be clarified that while this is the emerging jurisprudence on rights of the poor, there may be deviances emerging from socio-economic and political alignment of judges. The social philosophy of individual judge does have bearing on outcome of a case where the Court does not sit en-banc but constitutes itself in two and three judges bench (Rajagopal, 2007).

The UN Committee on Economic, Social and Cultural Rights (CESCR), in its appraisal of the status of ICESCR and socio-economic rights in India, rebuked the poor track record on forced evictions by stating in its concluding remarks in May 2008 that : "The Committee [...] remains deeply concerned about the reports of displacement and forced evictions in the context of land acquisition by private and state actors for the purposes of development projects [...] and 
that members of disadvantaged and marginalised groups are adversely affected by such displacement from their homes, lands and their sources of livelihood. The Committee is also concerned that urban renewal projects, sporting events, infrastructure expansion, environmental projects and more recently, the designation of large areas as tax-free Special Economic Zones, have resulted in displacement of millions of families, most of who have not received adequate compensation and rehabilitation. Furthermore, the Committee is concerned about the lack of effective consultations and legal redress for persons affected by displacement and by forced evictions, and the inadequate measures to provide sufficient compensation or alternative housing to those who have been removed from their homes" (UN CESCR, 2008: 6). Thus, even though GoI had ratified ICESCR 1966, and is accountable to CESCR, and while the Supreme Court in the past had often upheld ICESCR in domestic law, evictions of slum dwellers are increasing in Indian cities with the judiciary perpetuating the anti-poor bias (HRLN, 2006). Ahmedabad, New Delhi and Mumbai, known to aggressively pursue a neoliberal agenda, are the forerunners in such development-induced evictions (HRLN, 2006). High courts usually follow the judgements of the Supreme Court in their jurisprudence. The High Court of Gujarat is commonly believed to be sympathetic to the poor to the extent of "staying" or temporarily halting evictions. In legal parlance in India "staying" is the act of temporarily stopping a judicial proceeding, until an appeal can be heard, through the order of a court. However, in the context of the emerging jurisprudence on socio-economic rights of (unpropertied) slum dwellers in India, the stance of the Gujarat High Court on their rights and outcome of claim making process for the poor is not known. This inquiry is answered in chapter 4 of the thesis.

\subsection{Stance of Ahmedabad Municipal Corporation on slums}

Ahmedabad, historically a trading and textile city, is also the city where Gandhi resided for a large part of his life. It has a population of 5.6 million in the municipal area and 6.3 million in the Ahmedabad Urban Agglomeration (AUA), which extends beyond the municipal boundary and includes four towns and 103 villages covering a total area of 1866 square $\mathrm{km}$. It is the seventh largest metropolis of India and the largest city of Gujarat (Registrar General \& Census Commissioner, 2011). The municipal area, covering 466 square $\mathrm{km}$ is constituted by 64 municipal wards and is planned and developed by AMC. The Ahmedabad Urban Development Authority (AUDA) is the urban planning authority for the AUA area (Ahmedabad Municipal Corporation, 2007). 
Table 5: Demographic growth rate of AMC and AUA 1981-2011

\begin{tabular}{|c|c|c|c|c|c|}
\hline Year & \multicolumn{2}{|c|}{ AMC } & \multicolumn{2}{c|}{ AUA } & Gujarat urban \\
\cline { 2 - 5 } & $\begin{array}{c}\text { Population } \\
\text { (Millions) }\end{array}$ & $\begin{array}{c}\text { CAGR over } \\
\text { previous } \\
\text { decade }\end{array}$ & $\begin{array}{c}\text { Population } \\
\text { (Millions) } \\
* * *\end{array}$ & $\begin{array}{c}\text { CAGR over } \\
\text { previous } \\
\text { decade*** }\end{array}$ & $\begin{array}{c}\text { of } \\
\text { previous } \\
\text { decade }\end{array}$ \\
\hline 1981 & 2.06 & 3.1 & 2.55 & 3.5 & 3.5 \\
\hline 1991 & 2.88 & 2.9 & 3.31 & 2.7 & 2.9 \\
\hline 2001 & 3.52 & 2.0 & 4.52 & 3.2 & 2.9 \\
\hline 2011 & 5.57 & 4.7 & 6.35 & 3.5 & 3.1 \\
\hline
\end{tabular}

Source: Compiled from AMC data sources

The peripheral areas of the city have registered a higher population growth rate than the central parts. Hence, the Compound Annual Growth Rate (CAGR) of the AUA area was higher than that of the AMC area except in 2010 when the latter's boundary was extended (Table 5).

Ahmedabad, has a segmented spatial pattern with the low income group predominantly living in East Ahmedabad and the walled city on the east of the Sabarmati River and the affluent living in West Ahmedabad (Dutta, 2000). The earliest low-income settlements in the city were the chawls, single-room housing units built for the industrial workers in the proximity of the textile mills in East Ahmedabad. Controls on rent imposed by the Rent Control Act (1947), to safeguard the interest of poor tenants kept the rents extremely low, discouraging maintenance by the owners and resulting into deterioration of the chaw/s. From the 1950s onwards, urban growth affected the eastern and western peripheries where illegal occupation of marginal areas led to formation of slums by newly arrived migrants. Thus there are two types of low income settlements in the city: chawls originally built near the mill premises for workers and slums that represent illegal occupation of marginal areas of the city along the river and lakefronts, in low lying areas, and on vacant private or government land (Tripathi, 1998). The Gujarat Slum Areas (Improvement, Clearance and Redevelopment) Act1973 defines a slum as a compact area with a collection of poorly built dwellings which are mostly of a temporary nature, crowded, with insufficient living space, inadequate sanitary and drinking water facilities and insecure land tenure (Government of Gujarat, 1973). Because of the last characteristic, in a neoliberal economy which is predicated on property rights for capital accumulation, slum dwellers are referred to as "unpropertied" (Ghertner, 2008) citizens and distinguished from "propertied" citizens not living in slums. In this research, I use Ghertner's (2008) "property" based distinction to study the consequences of neoliberalisation on two social groups: the propertied and the unpropertied. 


\subsubsection{The changing stance of AMC on right to basic services}

In 2001 and 2010, respectively $25 \%$ and $15 \%$ of the total population of Ahmedabad lived in slums (Table 6). Slums have catered to the shelter needs of the migrants, without statutory permissions by the statutory development plan and building by-laws and are deemed illegal. Hence they are excluded from access to basic services in general, except for slums covered under slum upgrade projects, of which there were many till the neoliberal turn in the mid1990s, including the acclaimed Slum Networking Program (Dutta, 2000).

Studies have shown that till the neoliberal turn, AMC had a welfare approach towards slums (Dutta, 2000, UNHABITAT, 2003). With a legacy of Gandhian values, a strong economic base of textile industries (until their collapse in the mid-1980s), and vigorous Civil Society Organizations (CSOs), initiated by Gandhi through the establishment of the Textile Labour Association, AMC nurtured inclusive development and implemented various slum upgrade programs in collaboration with the CSOs and NGOs. Two important partnerships were the Slum Networking Program (SNP), focused on in-situ upgrade of slums through provision of basic services and granting of de-facto tenure rights (Dutta, 2000) and the Nirmal Gujarat Sanitation Plan which focused on demand-based construction of toilets for slum households. However, some have argued that the coverage of these programs has also been limited and the non-covered slums continue to be denied access to basic services even though provision of basic services like water supply and sewerage is an obligatory function for the AMC (Mahadevia, 2002, Tripathi, 1998).

Since the neoliberal turn, AMC has stopped investing in slum upgrade programs and turned to a market logic of "self-financing" of basic services and cutting losses, as discussed in the first section of this chapter. What this turn implies for access to basic services by the poor is not fully clear. Are they able to negotiate this right with AMC through participatory platforms (Ward Committee and Area Sabhas) or do they claim the right through the judiciary? How does the judiciary respond to their claims? Is the claim making process influenced by neoliberalism? From my pilot field visits, I had gathered that a group of community leaders had initiated a claim making process for right to basic services but not much was known about the process or its outcome. The above questions I seek to answer in chapter 4 of the thesis.

\subsubsection{The changing stance of $A M C$ on shelter rights}

Evictions were not common in Ahmedabad until the 1990s. Only a few settlements along or on road space reserved in the statutory development plan were cleared and "eligible" families before the prevailing cut-off date were given compensatory shelter. In India, the dwellers of "notified" slums which are surveyed and notified by local government as per the "Slum Act" of the 
respective State government are considered eligible for compensatory shelter on eviction (Bhan et al., 2014). AMC last notified slums under provision of Gujarat Slum Areas (Improvement, Clearance and Redevelopment) Act, 1973 in 1976 ! Since 1976, dwelling units in slums have more than doubled in number (Table 6) but new slum sites and dwelling units there-in remain un-notified and therefore ineligible for compensatory shelter upon eviction.

Table 6: Details of slum surveys by AMC

\begin{tabular}{|c|c|c|c|c|}
\hline \multirow[t]{2}{*}{ Details } & \multicolumn{4}{|c|}{ Year of slum survey by AMC } \\
\hline & $\begin{array}{l}1976 * \\
\text { (Notified) }\end{array}$ & $1992 \#$ & $2001 \#$ & $2010 @$ \\
\hline Slum sites (No.s) & 1.200 & 1,023 & 710 & 692 \\
\hline $\begin{array}{lll}\text { Slum } & \text { dwelling } & \text { units } \\
(\text { No.s }) & & \\
\end{array}$ & 81,255 & 92.121 & 176,754 & 166,381 \\
\hline $\begin{array}{l}\text { Cumulative change in } \\
\text { dwelling units (\%) }\end{array}$ & & & & $105 \%$ \\
\hline $\begin{array}{l}\text { Current composition of } \\
\text { dwelling units of notified } \\
\text { slums in total }(\%)\end{array}$ & & & & $49 \%$ \\
\hline Slum population & 415,103 & 615,316 & 883,770 & 831,905 \\
\hline $\begin{array}{l}\text { Cumulative Change in } \\
\text { slum population }(\%)\end{array}$ & & & & $100.4 \%$ \\
\hline $\begin{array}{l}\text { Current composition of } \\
\text { population of notified } \\
\text { slums in total }(\%)\end{array}$ & & & & $50 \%$ \\
\hline $\begin{array}{l}\text { Ahmedabad Population } \\
\text { (Municipal) }\end{array}$ & $2,059,725$ & $\begin{array}{l}2,876,71 \\
0\end{array}$ & $\begin{array}{l}3,520,08 \\
5\end{array}$ & $\begin{array}{l}5,583,47 \\
1\end{array}$ \\
\hline $\begin{array}{l}\text { Slum population in total } \\
\text { population }(\%)\end{array}$ & $20 \%$ & $21 \%$ & $25 \%$ & $15 \%$ \\
\hline
\end{tabular}

Source: Compiled by the author from sources (AMC and NGOs)

Note:

* The first and the last survey to be notified under Gujarat Slum Areas (Improvement, Clearance and Redevelopment) Act 1973, i.e. the slums covered under this survey are deemed eligible for resettlement on eviction.

\# The surveys of 1992 and 2001 were conducted for AMC by appointed NonGovernmental Organisations (NGOs) but both these surveys remained unratified by AMC and the state government and hence non-notified.

@ The survey was conducted for AMC by a private firm but remains unratified.

After the 1976 survey and notification of slums, AMC commissioned NGOs and private agencies to conduct surveys, for enumeration and mapping of slums, in 1992, 2001, 2010, respectively (Table 6) but none of the three surveys was ratified. Contestations around enumeration and mapping between slum community leaders and a few councillors are believed to be one of the primary 
reasons for the lack of notification. The 1992 and 2001 surveys were outsourced to NGOs and the 2010 survey, as part of settlement and household biometrics enumeration mandated under GoI's Rajiv Awas Yojana program, was outsourced to a private consultant.

As the post-1976 surveys remained unratified, the vulnerability of the post1976 slums to evictions may have increased. AMC's general cut-off date of 1976 is more backdated than most Indian cities. For example, in Mumbai the cut-off date is 1995, though for special cases 2001 is allowed, whereas for Delhi the cut-off date has moved from 1990 to 1997 to 2004, and most recently to 2007 (Bhan et al., 2014). In Ahmedabad, the cut-off date for slum households evicted under the riverfront development project was 2002. SRFDCL had commissioned a private agency to conduct a survey for mapping and enumeration of slum households living in influence area of the project and in December 2002 which became the cut-off date for the project after the survey was ratified by SRFDCL. However, it is not clear whether AMC was involved in the ratification process (Concerned Citizens of Ahmedabad, 2010).

The AMC has turned to implementation of beautification and infrastructure projects and commodification of the commons like riverfronts and lakefronts where many slums in Ahmedabad are located (Figure 6). Is the right to shelter of such slum dwellers recognised and if not, who would get compensatory shelter? Would the general cut-off date of 1976 be applicable or is it altered like in other cities? Are slum dwellers able to negotiate their rights through the participatory platforms (Ward Committee and Area Sabha) or do they claim their rights through the judiciary? How does the judiciary respond to their claim making process? Is the claim making process influenced by neoliberalism and, if so, in what ways?

From my initial field visits I had gathered that a community had filed a petition to claim right to shelter and revision of cut-off date for compensatory shelter in case of unavoidable eviction. But not much was known about the process or its outcome. These are issues I address in the chapter 4 of the thesis. 


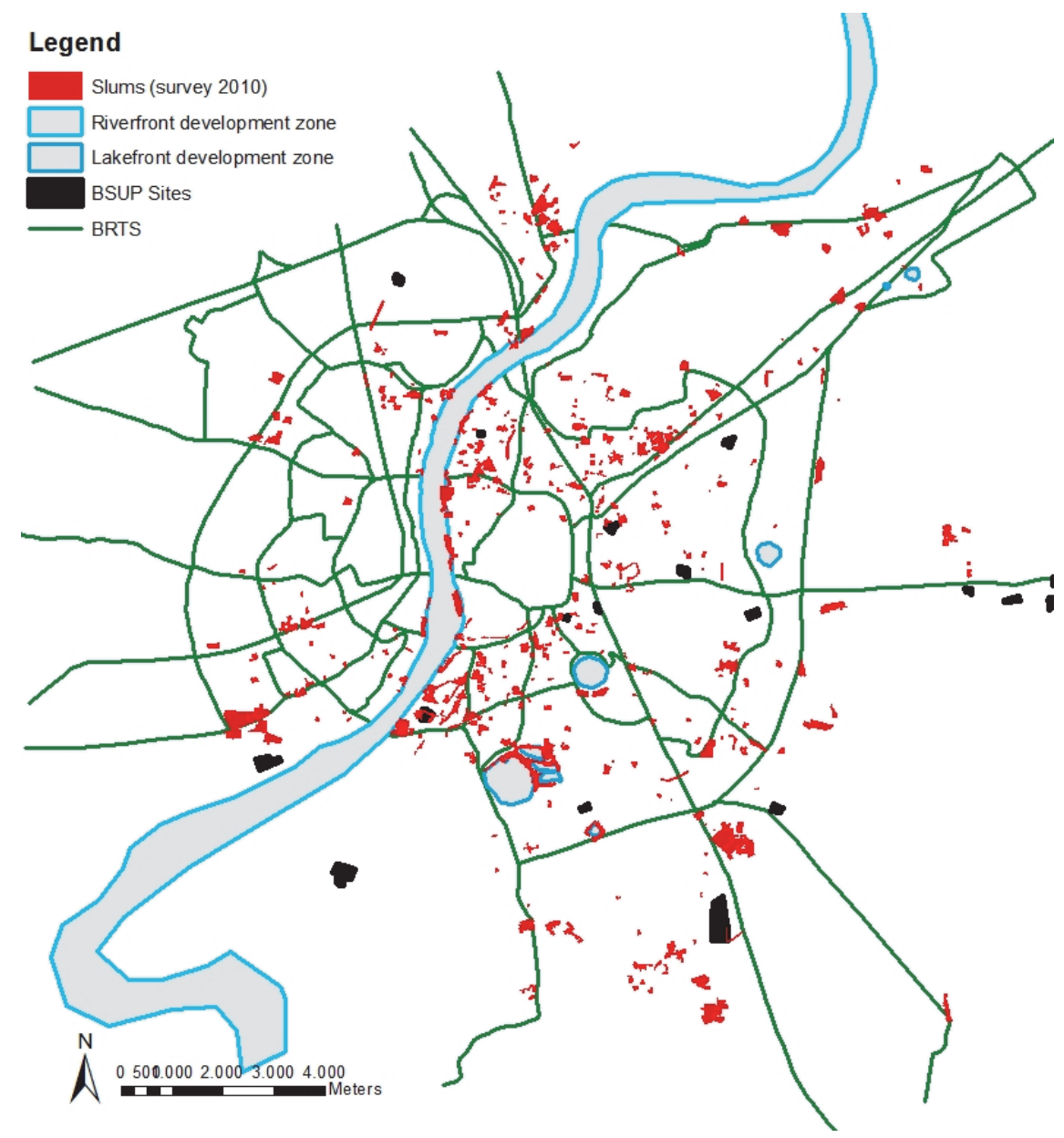

Figure 6: Locations of slums (2010 survey) and displacement inducing projects (BRTS, Riverfront and lakefront development)

Source: Compiled by author from sources (AMC, NGOs and Primary surveys from 2010 to 2014 )

\subsubsection{Neoliberal socio-spatial reconfiguration and consequences?}

On one hand, beautification and infrastructure projects are being implemented to improve the city's image, attract global investments and boost the quality of life for the city's propertied middle class which also whole-heartedly supports these transformations. But on the other hand the land for such projects is being expropriated from the unpropertied slum dwellers with compensatory shelter offered to a few, on BSUP sites in the periphery, possibly leading to their further impoverishment (Figures 7 and 8 ). The socio-spatial order of the city appears to be reconfigured on a property basis. I address these issues in chapter 5 of the thesis. 


\section{Legend}

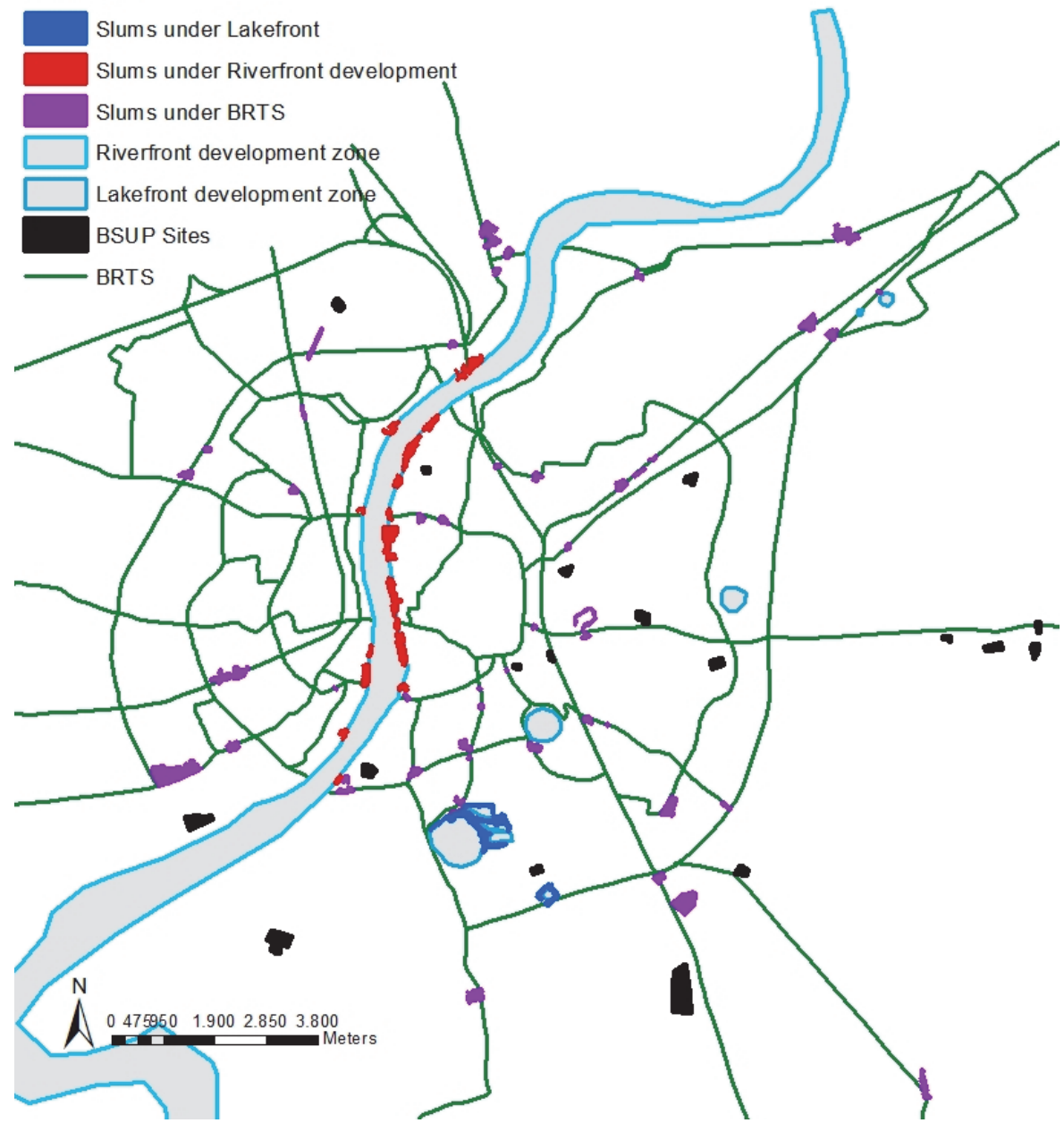

Figure 7: Slums to be displaced by projects (BRTS, Riverfront and lakefront development)

Source: Compiled by author from sources (AMC, NGOs and primary surveys from 2010 to 2014)

\subsection{Empirical context in a nutshell}

In a nutshell, the empirical context can be described thus:

First, the decentralisation and participatory governance frameworks were initiated through the 74th Constitutional Amendment Act (CCA) in 1992. In theory, participatory governance offers opportunities to citizens representing different social groups to deliberate on resettlement policy and negotiate their socio-economic rights with the local government. The Government of Gujarat ratified the Act in 1997, but institutionalised Ward Committees (WCs) as late as 2007 and Area Sabhas (ASs) in 2012. Little is known about how 
institutionalised participatory spaces function in Ahmedabad and how (un)equal opportunities are for (un)propertied citizens.

Figure 8: Slums eligible for compensatory shelter on eviction (1976 surveyed Legend and 2002 surveyed in riverfront)

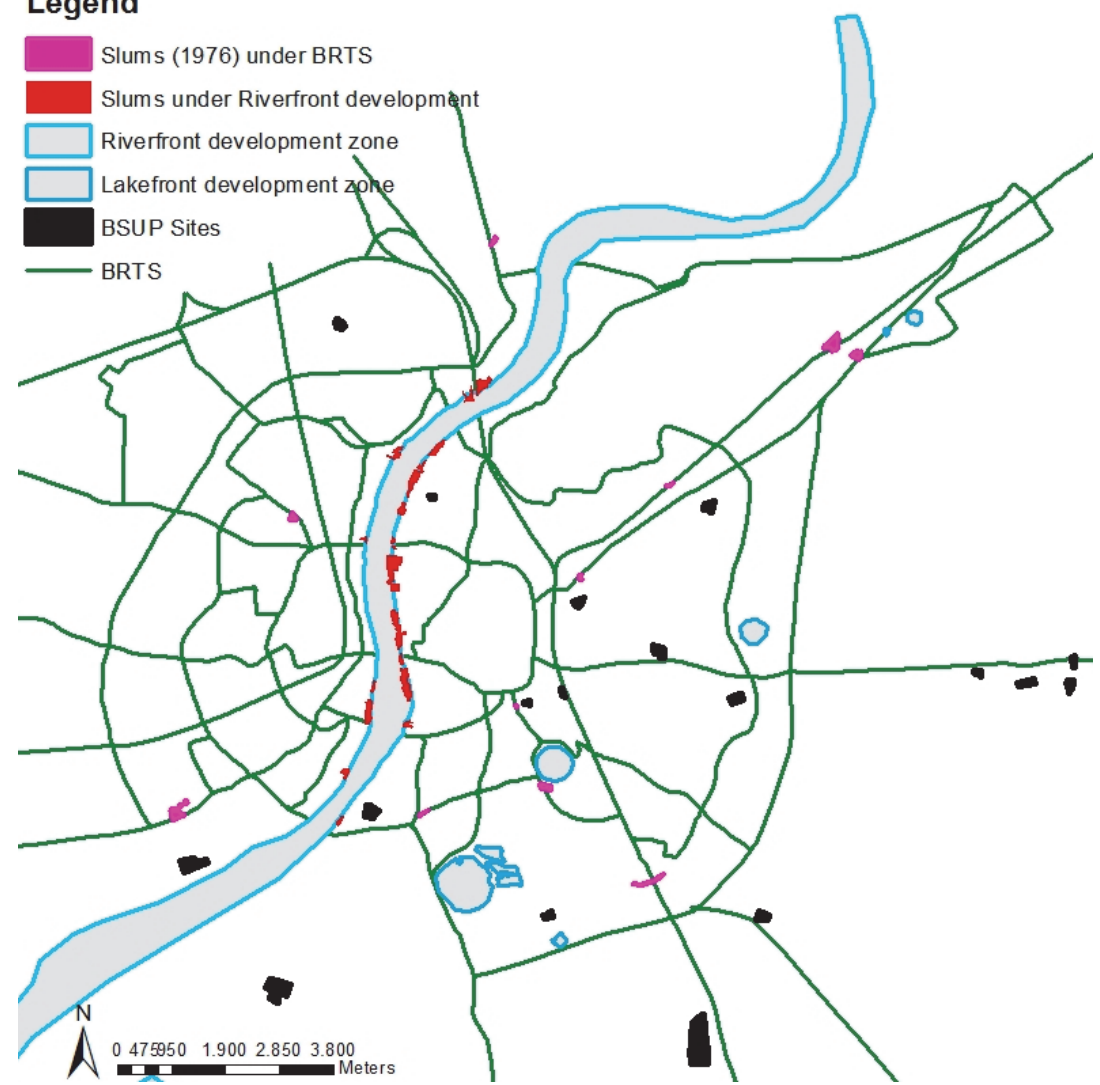

Source: Compiled by author from sources (AMC, NGOs and primary surveys from 2010 to 2014)

Second, the neoliberal turn in governance in Ahmedabad and the GoG initiated in the mid-1990s, is manifested in five shifts: (1) introduction of a market logic of functioning in few services without entering into institutionalised partnerships with private capital, (2) outsourcing of a few services by entering into institutionalised partnership with private companies, (3) formation of semi-autonomous bodies outside the arena of political deliberation for efficient delivery of high priority projects, (4) initiation of beautification and infrastructure projects in the core city area which would improve the city's image and attract new businesses and evict slums, and (5) conversion of commons and land parcels formerly reserved for housing the poor to profitable use. These shifts are projected by GoG as a gateway for national and global investments into Gujarat and as a model of neoliberal development of the State 
through the biennial Vibrant Gujarat Global Investment Summits. Gujarat's neoliberal turn is more aggressive than the Indian average causing arguably higher inequalities. Little is known about the consequences of the neoliberal turn for the rights and well-being for (un)propertied citizens.

Third, the Supreme Court of India and the High Courts of states may be perpetuating the neoliberal bias through anti-poor judgements to claims of unpropertied slum dwellers. This emerging jurisprudence in India, may influence the stance of the Gujarat High Court, which is expected to play a significant role in upholding the socio-economic rights of the poor in the short and long term. Little is known about how Gujarat's High Court upholds or denies the socio-economic rights of unpropertied citizens.

Fourth, evictions of slum dwellers may have differential effects on various social groups and the city's socio-spatial order. They may boost the quality of life of propertied citizens and negatively affect that of slum dwellers' resettled to distant sites. Little is known about how different consequences for different social groups lead to socio-spatial reconfiguration of the city.

In the next chapter I review the extant literature around the key relevant concepts of neoliberalisation, decentralisation, participation and socio-spatial reconfiguration of cities which form the core of this study. 
Chapter 2

Theoretical framework and research strategy 
In this section, I situate key concepts and relationships emerging from the empirical context within the literature and formulate the research questions of this thesis.

\subsection{Review of extant literature on key concepts}

The projection of Ahmedabad as a "world-class" city in the Vibrant Gujarat summits can be illuminated through Sassen's (1991) "global cities" theorem. This theorem posits that the increasing globalisation of production, finance and information systems have led transnational corporations to develop agglomeration economies of control and command in strategically important cities. Corporations take advantage of economies of scale and use "global cities" as the central marketplace for key industries, as central hubs for research and development and as head offices for the organization of the world economy.

While Sassen's (1991) "global cities" of developed nations are major nodes of global value chains and capital flows, "globalising cities" in developing nations are nurturing the necessary professional class and urban environs to become secondary and tertiary nodes in these global chains (Marcuse and Van Kempen, 2000, Sandhu and Sandhu, 2007). Scholars have been debating whether globalisation has been ongoing for centuries or is a late $20^{\text {th }}$ century phenomenon (Appadurai, 2001). However, it may be assumed that globalisation of production capital was expanded in 1989 through the Washington Consensus (Smith, 2002).

Political economists (Goodwin and Painter, 1996, Jones, 1999, Harvey, 1989) have shown that globalisation affects urban governance in three ways: urban areas are rescaling by devolution of powers, functions and resources from the national to the local government level; policy is reoriented away from redistribution of income and towards competition for capital; and a market logic with focus on efficiency and profit maximisation dominates. The first effect underpins "decentralisation", while the second and third effects underpin the "neoliberalisation" of urban governance (Crook and Sverrisson, 2003a, Eaton, 2001, Purcell, 2003).

\subsubsection{Decentralisation}

With the sub-national rescaling of urban areas, local governments accept more responsibility as national governments devolve power, duties and funds to them. Devolution, often termed "democratic decentralisation" (Eaton, 2001), means that local governments are increasingly responsible for economic development, provision of infrastructure, spatial planning and urban policy making (Painter, 1995). Decentralisation may be accompanied by further rescaling of power, duties and resources from local to lower tiers of government through the opening of participatory spaces with the objective to 
deepen citizen participation and facilitate negotiation of their needs (Cornwall and Gaventa, 2001, Gaventa, 2006, Baud and deWit, 2009). The additional sub-local rescaling is referred to as "participatory governance" (Gaventa, 2006).

Decentralisation is contextual, takes different shapes and has mixed results across the globe (Crook and Manor, 1998, Turner and Hulme, 1997). In India, rescaling at sub-national and sub-local levels was effected through the $74^{\text {th }}$ Constitutional Amendment Act (74 ${ }^{\text {th }}$ CAA 1992) and JNNURM's Community Participation Law (CPL) reform in 2005. Thus, the Ahmedabad Municipal Corporation (AMC) assumed responsibility for economic development, provision of infrastructure and spatial planning, while rules for sub-local rescaling were enacted much later, in 2006 and 2012, when the participatory spaces Ward Committees (WCs) and Area Sabhas (ASs), respectively) were made a prerequisite for availing grants from the Government of India (GoI).

\subsubsection{Neoliberalisation}

The increased autonomy of local governments is accompanied by a shift in their policy orientation from redistribution of income towards competitiveness for capital and a shift to a market logic of functioning with focus on efficiency and profit maximisation (Harvey, 1989, Swyngedouw, 2005, Ong, 2006) implemented through national economic restructuring.

Prior to economic re-structuring, urban governance was administering national redistribution schemes. As economic re-structuring makes the local economy increasingly independent of the national economy, local governments become more concerned with ensuring that urban areas can compete effectively in the global economy for attracting capital. Thus, economic development and competitiveness and not social redistribution become the primary imperatives that drive local policy-making and local governments increasingly engage in interventions designed to attract investment to urban areas (Painter, 1995, Purcell, 2003).

Functioning with a market logic marks a shift from the welfare-oriented "managerialism" of the past and is accomplished by public-private partnerships carrying out many of the former functions of local government (Payne and Skelcher, 1997). Market actors, not directly accountable to the local electorate, make decisions which are not subject to conventional democratic control, raising fears of excluding citizens from decisions that shape their cities (Purcell, 2003). Democratic deliberation is deemed inefficient and inappropriate for efficient service delivery (Hay and Jessop, 1995). A neoliberal "government of free individuals who are then induced to self-manage according to market principles of discipline, efficiency and competitiveness" (Ong, 2006:6) replaces welfare-state patrimonialism, citizens are increasingly freed of the state, 
provide for themselves and supposedly to optimize their market participation to increase their wealth and consumption.

Neoliberalisation produces hybrid, constantly changing socio-spatial orders that are geographically and historically contingent. Neoliberalising cities take different shapes, depending on pre-existing institutional practices, regulatory environments, socio-political power relations and space use (Brenner and Theodore, 2002). Local governments ground policies of privatisation, competition and reduction of public expenditure in their specific urban contexts, a phenomenon called "actually existing neoliberalism" by Brenner and Theodore (2002). The "actually existing neoliberalism" in Ahmedabad has its roots in the neoliberalisation policies of Gujarat State, which in turn were initiated under the economic liberalisation and globalisation policies of GoI. The five shifts towards neoliberalisation, described in Section 1.3.4, broadly fall in line with the literature.

In sum, decentralisation and neoliberalisation are two sides of the same global restructuring process, and are usually simultaneously launched in urban governance (Purcell, 2003, Goodwin and Painter, 1996). However, while neoliberalisation heralds policies towards market-oriented economic growth, participatory governance purports to offer opportunities to those without exchange entitlements to participate in policy formulation and negotiate rights to improve their well-being. Research on the consequences of these combined reforms shows that despite the rhetoric of inclusion of citizens in urban transformation through decentralisation, urban governance excludes local inhabitants from decisions that shape their cities, leading to their growing disenfranchisement (Brodie, 2000). However some researchers (Baud and deWit, 2009, Gaventa, 2006, Chatterjee, 2004) argue that not all citizens are disenfranchised, and that some social groups lacking exchange entitlements, such as the unpropertied citizens, experience a higher level of inequalities than propertied citizens in realizing their rights. I now turn to the literature on implications of the two reforms on citizens' rights and well-being.

\subsubsection{Citizens' rights and well-being}

Citizenship, as defined by Marshall in his classic framework, consists of civil, political and socio-economic rights. Civil rights include "the rights necessary for individual freedom-liberty of the person, freedom of speech, thought and faith, to own property and to conclude valid contracts, and the right to justice"; political rights include "the right to participate in the exercise of political power, as a member of a body invested with political authority or as an elector of the members of such a body"; and socio-economic rights "range from the right to a modicum of economic welfare and security to the right to share to the full in the social heritage and to live the life of a civilised being according to the standards prevailing in the society" (1950:30). Whilst formal citizenship refers 
to formal membership to a nation state, substantive citizenship refers to the civil, political and socio-economic rights citizens enjoy within a given society to ensure their well-being (Appadurai and Holston, 1996). Though many definitions of well-being exist (Griffin, 1986, Rawls, 2009), I find the conception of well-being as "realisation of key socio-economic rights" useful, given that civil and political rights are fundamental rights in India that are de facto granted to each Indian citizen.

The significance of socio-economic rights for substantive citizenship is emphasized by Plant who notes, "citizenship confers a right to a central set of resources which can provide economic security, health and education - and this right exists irrespective of a person's standing in the market" (1992 : 16). This liberal conception of rights was used to undergird the concept of the welfare state, establishing a universal set of benefits to which citizens should be entitled. Contrary to this social citizenship ideal stands the powerful and pervasive neoliberal ideal which asserts that state abstention from socioeconomic protection is the foundation of a good society (McCluskey, 2003).

The United Nations combined rights into two groups-civil and political rights in one group, and socio-economic rights in the other group. Both groups of rights were deemed equally important to human welfare in the Universal Declaration of Human Rights (UDHR) in 1948. However the vision that the two groups of rights should be kept separate won when UDHR was translated in 1966 into two covenants: the International Covenant on Civil and Political Rights (ICCPR) and the International Covenant on Economic, Social and Cultural Rights (ICESCR). The latter is the vision advocated by political philosophers (Gavison, 2003). Western theories of political justice and liberalism make civil and political rights a necessary component of the liberal, democratic state but do not include socio-economic rights in the order of rights (McCluskey, 2003). The Indian Constitution holds that civil and political rights considered as fundamental rights are legally enforceable, while socio-economic rights are directive principles for the state policy and hence implied rights.

Consequently, though most democratic nations today, including India, have ratified both international covenants and are legally bound by them, many continue to sacrifice the socio-economic rights of marginalized citizens (McCluskey, 2003). For example, countries that have ratified ICESCR have not adopted shelter rights legislation in their municipal laws, leaving evicted citizens without domestic legal powers to contest evictions unless they appeal on the grounds of infringement of civil-political rights as has been done by the evicted poor in India (UNCHR 2005).

Under the two reforms in urban governance, decentralisation opens new avenues for participation in political process whereas neoliberalisation has 
implications on socio-economic rights, particularly for those without exchange entitlements (Cornwall and Gaventa, 2001, Baud and deWit, 2009, Purcell, 2003). Gavison (2003) proposes that civil-political rights promote the ability to fight effectively for socio-economic rights and to minimize socio-economic catastrophes and ensure well-being. I find this conception useful as I seek to inquire the tensions between the two processes.

\subsubsection{Socio-spatial order}

Socio-spatial order is the projection of social structure and associated socioeconomic inequalities onto space (Haussermann et al., 2008, Marcuse and Van Kempen, 2000). Social cleavages manifest themselves in terms of socioeconomic position, education, housing or property basis, and political representation (Smet and Salman, 2008). Inequality occurs when resources in a given society are distributed unevenly, typically through norms of allocation, that engender specific patterns along lines of socially defined categories of persons such as poor and rich, property ownership basis, ethnicity basis and religious basis among many others. Inequality does not necessarily impact the spatial order and Marcuse and Van Kempen (2000) propose that variations in capital accumulation regimes and capital flows are among the four key forces through which it is manifested. The other three they mention are demographic changes with change in work opportunities, xenophobia and racism, and the changing role of the public sector in housing that forces people to rely more on market strategies for access to housing (ibid). Urban regeneration and private capital investments in core city neighbourhoods and displacement of low income groups as they are outpriced or ousted (if unpropertied) are examples of social inequality manifesting in spatial order (Smith, 2002, Marcuse, 2009).

\subsection{Review of extant literature on key relationships}

Having positioned the salient concepts within the literature, I now review the literature on key cause-effect relationships between them.

\subsubsection{Consequences of decentralisation on citizens' rights, well- being and social inequalities}

Citizenship in liberal democracies implies civil, political and socio-economic rights (McCluskey, 2003). Decentralisation and devolution of powers, duties and functions from national to local governments and further to lower participatory tiers in local governance imply new political rights through opportunities to participate in Gaventa's (2006) "invited" spaces. He defines "spaces" in general as "opportunities, moments and channels where citizens can act to potentially influence policies, discourses, decisions and relationships which affect their lives and interests" (2006: 26), and proposes three interrelated types of spaces: closed, invited and claimed spaces. In "closed spaces" citizens are not allowed any say in decisions taken by the state. "Invited spaces" are those where the state offers citizens the possibility of 
participation in decision making processes. They may be institutionalised and permanent or transient. In "claimed spaces", marginalised citizens mobilise to create opportunities to negotiate their socio-economic rights with the state as self-organised autonomous agents.

Scholars who support decentralisation argue that it enhances proximity of local government to citizens and can match policies and service delivery with the actual needs of citizens (Cornwall and Coelho, 2007, Cornwall and Gaventa, 2001, Baud and deWit, 2009, Gaventa, 2006). They argue that decentralisation gives citizens the opportunity to participate in urban transformation, to negotiate their socio-economic rights and ensure their well-being. However, they caution that invited spaces are meaningful if they allow citizens to be "makers and shapers" rather than just "users and choosers" of services, implying that the spaces should provide a platform for citizens to participate in policy making rather than merely to negotiate their needs as service consumers (Baud and Nainan, 2008, Cornwall and Gaventa, 2001).

Those sceptical of decentralisation argue that participatory spaces are designed by the state to capture local elites and thus further disempower marginalized groups (Swyngedouw, 2005, Crook and Sverrisson, 2003a). They argue that local government may be reluctant to share substantive power with citizens on the grounds that citizens' interests may override interests of the city as a whole (Baud and deWit, 2009) or because of the neoliberal bias that democratic deliberation is inefficient (Hay and Jessop, 1995). Swyngedouw (2005) cautions that though participation may have a sympathetic ring, it may in fact be an attempt of the neoliberal state to confer tasks upon elite citizens under arrangements that are not democratic, non-transparent and fuzzy. In short to include some and to exclude others.

Yet other scholars dismiss the risk of "elite capture" (Cornwall and Gaventa, 2001, Fung and Wright, 2003b, Gaventa, 2006) on the grounds that, should it occur, marginalised citizens may mobilise or take judicial recourse to claim spaces to negotiate their socio-economic rights with the state. Gaventa (2006) suggests that claimed, closed and invited spaces exist in a dynamic interrelation, and are constantly opening and closing through struggles for legitimacy and resistance, co-optation and transformation. Closed spaces may serve to restore legitimacy by being transformed into invited spaces and similarly invited spaces may be created as people's movements attempt to use their own fora to engage with the state. Participatory spaces are therefore often fluid (ibid). Ideally a dynamic interrelation between these spaces may lead to a just social order wherein all social groups have equal power and are able to negotiate their rights and well-being (Gaventa, 2006). Ward Committees and Area Sabhas may be viewed as invited spaces but the neoliberal Gujarat State and AMC may not be willing to share power with 
citizens in these spaces if they deem democratic deliberation inefficient, while elite capture of these spaces by the propertied middle class is a definite risk. Where stakes are high and resources available, the unpropertied poor may mobilise and claim spaces through the judiciary and may open closed spaces to negotiation.

\subsubsection{Consequences of neoliberalisation for citizens' rights, well- being and social inequalities}

Neoliberalisation affects socio-economic rights (Appadurai and Holston, 1996, Ong, 2006, Rose, 1999). Whilst access to substantive rights is in theory dependent on full formal citizenship, neoliberalisation is increasingly challenging this relation. Urban development policy increasingly grants substantive citizenship rights to owners of global capital who lack formal citizenship rights, whilst substantive, socio-economic rights are increasingly withheld from marginalized citizens (Appadurai and Holston, 1996). In this section, I discuss literature around the consequences of neoliberalisation on two sets of socio-economic rights-basic services and shelter-for propertied and unpropertied citizens.

Citizens are increasingly expected to provide for themselves and optimize their market participation to increase their wealth and consumption (Ong, 2006). They must realise their socio-economic rights, such as the right to basic services, in the market, a phenomenon called "self-responsibilization" by Rose (1999). The non-poor welcome an efficient market and what they perceive as freedom from an inefficient state. With the commodification of socio-economic rights, citizens become commodity consumers and only those who are able to pay can realise them (Ong, 2006, Bhan, 2009, Rose, 1999). Inequality becomes an inevitable part of neoliberal governance with some citizens becoming more equal than others, with more rights than others (Appadurai and Holston, 1996, Bhan, 2009, Ong, 2006, Rose, 1999). Citizenship in the liberal democratic use of the term as defined by Plant (1992) is rearticulated.

Harvey (1989) discusses similar consequences on right to shelter in entrepreneurial cities from the perspective of increasing competitiveness for capital through "city imagineering and place marketing" practices. In order to attract global capital, entrepreneurial cities enter into global competition by redeveloping existing and building new consumption oriented spaceswaterfront developments, cultural spectacles and enterprise and trade zones. This leads to displacement and the increasing speculative production of place. Cities are increasingly shaped as places for higher classes and exclude, marginalize and remove citizenship rights of lower income groups. The valorization of urban space through speculative production of place becomes a key strategy for capital accumulation and property rights give entrepreneurial cities relatively free reign to maximize their exchange value. The 
entrepreneurial city thus disavows shelter rights of the unpropertied, dispossesses and displaces them to "create an urban imagery" and "accumulate capital" (ibid).

With limited access to the markets, the poor frequently appeal to the judiciary to force the state to negotiate the terms for their socio-economic rights and well-being (Mahadevia, 2014). Thereby, the judiciary in India is playing an increasingly prominent role in urban governance issues related to the poor, not only as an arbiter of justice but also as a parallel administrative and executive body (Dupont and Ramanathan, 2008, Ghertner, 2008, Bhan, 2009). Scholars have shown that the judiciary in India has significantly contributed to the evolving jurisprudence of "illegality" of slums and shelter rights of urban poor (Ramanathan, 2006, Dupont and Ramanathan, 2008, Ghertner, 2008, Baviskar, 2003). Rajagopal (2007) argues that the stance of the higher judiciary in India on human rights has generally aligned with the Indian government's neoliberal ideology of development and growth. Moreover, high courts of individual Indian States usually follow the judgements of the Supreme Court in their jurisprudence. In this context, the stance of the Gujarat High Court on the rights of slum dwellers may be a key determinant of the outcome of their claim making.

Neoliberalisation naturalises inequality as an inevitable part of governance, with some citizens becoming more equal than others, with more rights than others (Appadurai and Holston, 1996, Bhan, 2009). For the propertied upper middle class, "self responsibilisation" for basic services means better services and improved well-being. "City imagineering and place making" increases the value of their property, consumption spaces and new businesses opportunities (Harvey, 1989). The rising middle class emerges as the favoured and powerful electorate, raising fears that the poor loose the edge of negotiating with elected representatives through clientelism, as they did in the past. The rising middle class may have devastating implications on socio-economic rights of the poor (Ghertner, 2011, Harvey, 1989, Dupont, 2011, Fernandes, 2004), when it frames slums as "environmentally harmful", a "nuisance" and an obstruction to their aspirations of a "world-class" city and mobilises to evict slum dwellers, as a result. Fernandes (2004) refers to this as the "politics of forgetting" the marginalized social groups leading to social polarisation.

\subsubsection{Consequences of neoliberalisation for a city's socio-spatial order}

Social inequalities have a spatial dimension which is visible in the core city and other vital city spaces undergoing going urban regeneration processes. Harvey's (2003) conception of "accumulation through dispossession" provides a useful account of the shift in socio-spatial order of an entrepreneurial city wherein capital is accumulated (by local governing institution(s) and the 
propertied citizens) by regeneration of strategically vital spaces in the city and by dispossession of the poor from these spaces. He argues that this process has a vital class dimension, as low-income groups and those lacking political voice usually suffer the repercussions. He warns that behind the mask of many "successful" projects lie serious social and economic problems and that, in many cities, these create a geographically dual city of inner city regeneration and a surrounding sea of increasing impoverishment.

The dispossessed are displaced to the city periphery and in so doing become more impoverished. Critics of dispossession and displacement suggest that the displaced are inevitably exposed to multiple forms of impoverishment and raised issues of social justice and equity (Cernea, 2000b, Cernea, 2000a, Fernandes, 1991, Mathur, 1998, Downing, 1996). Cernea's (2000b) Impoverishment Risks and Reconstruction (IRR) framework analyses the socioeconomic consequences of dispossession and displacement on the evictees and proposes risk mitigation strategies. His eight interlinked forms of social impoverishment include landlessness, homelessness, joblessness, loss of access to social amenities, morbidity and mortality, food insecurity, marginalization, and social disarticulation. Community participation in all aspects of a resettlement process is a key strategy to mitigate risk of resettlement failure. An additional source of impoverishment could be the lack of information on the planning and implementation of resettlement projects. The SRFD and BRTS projects were implemented on fast track basis by semiautonomous bodies (SRFDCL and $\mathrm{AJL}$ ) and their master plans and implementation details were not publicly disclosed, an otherwise mandatory requirement. Slum dwellers located within the influence area of these projects were evicted without consultations, while those "eligible" to be resettled had no information on resettlement and rehabilitation policies.

\subsection{Research questions}

The relationships which emerge from the review of the empirical context and related literature translate into three interlinked research questions summarised as follows:

\section{Sub-question 1: How are (un)propertied citizens affected by decentralisation initiatives?}

- How are participatory spaces created locally under the mandates of national and state governments?

- What opportunities do participatory spaces offer to the two social groups to deliberate on ward planning and budgeting processes and to negotiate their rights?

- How do the two social groups attempt to negotiate their rights and whose interests are best served?

- Is there a neoliberal bias in the decentralisation process in Ahmedabad? 
Sub-question 2: How does neoliberalisation affect key socio-economic rights of unpropertied citizens and the social order of the city?

- How do the poor attempt to negotiate their right to basic services and to shelter (incl. the cut-off date), in the absence of "invited" spaces?

- How does the judiciary respond to their claim making?

- How does local government respond to the judicial process?

- What is the judiciary's and local government's response to the rights of the unpropertied citizens and to "closed" spaces?

Sub-question 3: How is the socio-spatial order of the city influenced by neoliberalisation and what are the consequences for the evicted slum dwellers?

- How does neoliberalisation alter the city's socio-spatial order: are shelter rights denied and is capital accumulation and dispossession evident?

- What are the consequences of eviction for the well-being of the dispossessed slum dwellers?

- How were the risks of their impoverishment addressed in the resettlement policy?

- How was community participation in critical decisions related to eviction and resettlement addressed?

Main question: How do the tensions between decentralisation and neoliberalisation shape the rights of the citizens and the socio-spatial order of neoliberal Ahmedabad?

Figure 9 shows the relations between citizens, politicians/executives and the judiciary as they may exist in a just social order wherein all social groups are empowered to deliberate on urban transformation policies and able to negotiate their rights and ensure their well-being. These ideal relations form the conceptual framework of my research and are the point of departure for the following chapters. 


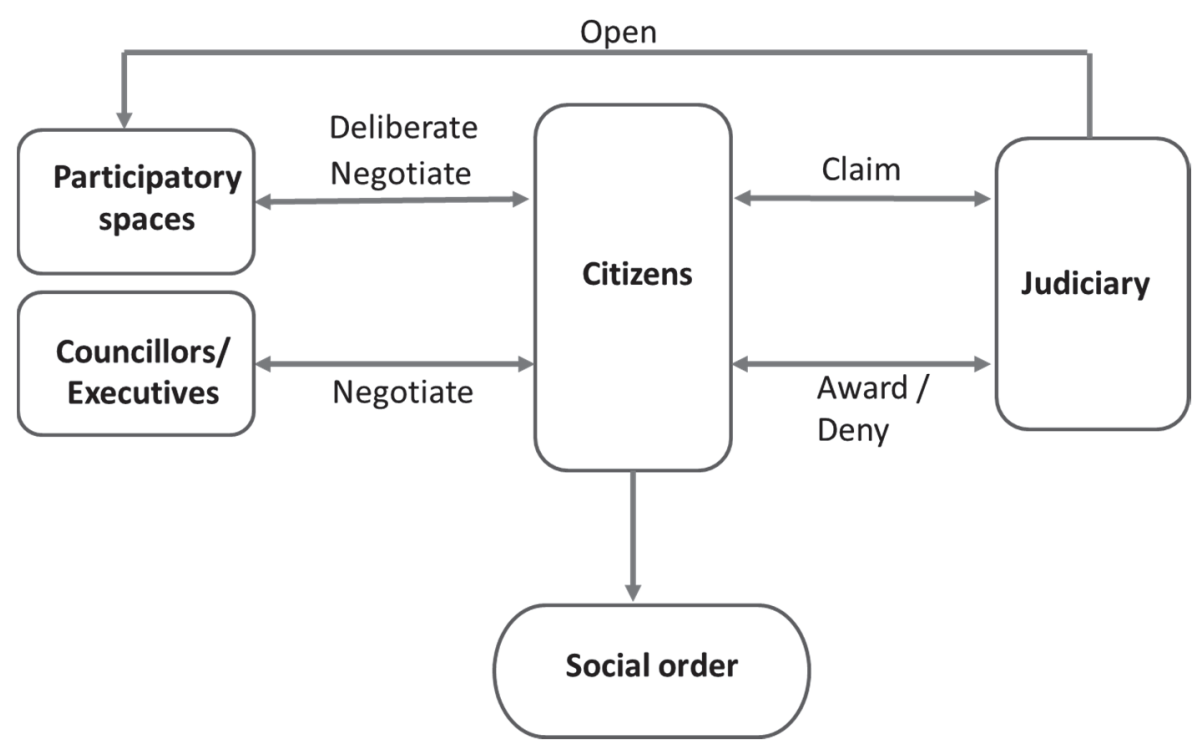

Figure 9: Conceptual framework

The answer to the main question led to an additional question: whether and how information transparency can catalyse the participation of unpropertied citizens in neoliberal regimes and enable them to negotiate their socioeconomic rights. I suggest ways to improve transparency to catalyse participation, especially of unpropertied citizens.

\subsection{Research strategy}

In this research I inquire how the tensions between decentralisation and neoliberalisation shape the rights of the citizens and the socio-spatial order of the city in the specific political, economic, judicial and social context of Ahmedabad within the macro settings of India and the State of Gujarat as discussed in chapter 1 . The research emerged from my engagement with the crises on ground - evictions of slum dwellers, resettlement of some to peripheries, their inability to negotiate rights with local government and judicial recourse for claiming rights. My inquiries around these issues led me to identify key issues around the poor which were related to the specific implementation of the decentralisation, participation and neoliberalisation; the constitutional frameworks at State level and the judiciary's interpretation of socio-economic rights, especially of the poor, AMC's stance on these rights and the socio-spatial order of the city. Identification of issues led me to review the empirical context in detail: the framing of issues in the macro setting of India and their implementation in the micro settings of the State of Gujarat and the city of Ahmedabad. From the detailed review of the empirical context, I identified the key concepts of neoliberalisation, decentralisation, participation, citizens' rights and socio-spatial reconfiguration of cities within which issues of unpropertied slum dwellers were situated and the emerging relationships. I 
situated these key concepts and relationships within the extant literature which led me to formulate interlinked sub-questions and central question of this research.

As the inquiry is exploratory in nature and set in the city of Ahmedabad, I adopt an empirically grounded exploratory research strategy (Eisenhardt, 1989, Charmaz, 2006), that warrants an interpretivist epistemology (Guba and Lincoln, 1994). An broad definition of the research question emerging from the extant literature is important in empirically grounded research (Eisenhardt, 1989, Charmaz, 2006). A priori specification of relationships also helped to shape the design of the empirically grounded research. This is a valuable strategy as it helps to measure relationships more accurately (Eisenhardt, 1989, Bettenhausen and Murnighan, 1986).

Such an empirically grounded research strategy necessarily draws on multiple methods of data collection as the triangulation made possible by multiple methods provides stronger substantiation of relationships (Yin, 1984, Eisenhardt, 1989, Hannerz, 2003). For each sub-question in this research, I draw upon multiple data collection methods, combining qualitative and quantitative evidences from interviews, field observations, focus groups discussions, documentary sources and questionnaire surveys. A feature of empirically grounded research is the overlap of data collection, data analysis, and sharpening the relationships through an iterative process until a point of theoretical saturation is reached, though the degree of overlap may vary. A continuous comparison and iteration between the data and conceptual relationships ensures that accumulating evidence from multiple sources converges on a well-defined relationship (Glaser and Strauss, 1967, Charmaz, 2006, Eisenhardt, 1989). The emergent relationships and concepts then are compared with the extant literature by asking what is it similar with and what does it contradict at a higher conceptual level (Eisenhardt, 1989).

For the first sub-question, "How are (un)propertied citizens affected by decentralisation initiatives", the iterative process involved multiple methods of data collection and simultaneous analysis of data. To analyse gaps in the State government policy for participatory governance with respect to the mandates by the National government, relevant documents were collected from both government levels, as well as from both analogue and digital data sources. The findings on gaps between the two mandates were corroborated by semistructured interviews of officials in State government and local government, members of academia, NGOs and slum dweller associations. The documents, interview transcripts and field notes were critically analysed and synthesised to understand the gap in mandates. To analyse the implementation of the State government policy for participatory governance by local government, relevant documents of AMC were collected and critically analysed. At the same time to 
get the perspectives of all the key stakeholders, semi-structured interviews of selected stakeholders were undertaken. Official claims related to participation in local governance processes were captured through interviews of officials across various levels in the Municipal Corporation and across wards of the city and councillors of both- the ruling and opposition political party. To gain insight into the gap between official claims and actual practices by AMC, I conducted semi-structured interviews of leaders of different associations of (un)propertied citizens across wards of the city, NGO members working with unpropertied citizens, and academicians. The field notes, transcripts and documents were critically analysed to understand the consequences of a participatory governance framework for different citizen groups. Thus I "circulated" to synthesise materials across sites and time and across empirical material ranging from digital sources, to government documents, field notes and interview transcripts (Hannerz, 2003) to create a grounded picture of consequences of participatory governance for different citizen groups and I compared the emergent relationship(s) with extant literature by asking what is it similar with and what does it contradict and explain the contradictions in the empirical settings. Detailed descriptions of the methods are presented in section 3.2 of chapter 3 and discussions of emergent relationship(s) with extant literature in section 3.4 of the thesis.

The second sub-question, "How does neoliberalisation affect key socioeconomic rights of unpropertied citizens and the social order of the city", was in continuum of the first sub-question and so were the field work, empirical material collection and analysis. However as the thesis is structured as synthesis of three sub-questions and publications, each marking a temporary point of closure in interpretations with specific audiences in mind, the methods for each sub-question are described discretely in each publication/ chapter. For this sub-question, I focused on two claim making processes initiated by two different slum communities, one seeking the right to basic services and the other seeking the right to shelter and revision of cut-off date (from 1976 to 1995) for compensatory shelter in case of unavoidable eviction. I use the claim making process as a backdrop to explore the stance of local government on rights of unpropertied citizens through the reply affidavits filed in the Court. As the cut-off date revision falls in the purview of the local and State government and both were made respondents in the petition, I could also explore the stance of the State government. Here also an iterative process involved multiple methods of data collection and simultaneous analysis of data. To understand the evolution of the case on the right to shelter and the cut-off date from the petition till the final judicial order and the governments' response to the order, documents were collected from five actors: local and the State government, the civil right activist group which was the petitioner on behalf of the slum community, and the High Court of Gujarat and Supreme Court of India, where the petition and appeal on the petition were filed. Media reports on the case 
were collected. I undertook textual analysis of these documents with the objective to understand each actor's position on (mis)recognition of rights of the poor by the local government. I identified discursive devices, turns of phrase producing a specific effect (Chilton and Schäffner, 2002), used by actors to advance their position. While the position of the State actors and petitioners on (mis)recognition of rights by AMC was known a priori (shown in Table 11 in chapter 4), the objective was to reveal the higher judiciary's position and discursive devices used by actors to advance their position (shown in Table 15 in chapter 4). To corroborate findings from textual analysis, I conducted semistructured interviews with the key actors including activists, slum community leaders, senior officials and councillors in AMC. Similarly, for the second petition on right to basic services, I collected documents from three key actors: AMC which was the respondent, Gujarat High Court where the petition was filed and the slum community association, which had filed the petition against AMC. These documents were analysed through textual analysis with the objective to reveal each actor's stance on the right to basic services of the unpropertied citizens. I present a detailed description of the methods for this sub-question in section 4.2 of chapter 4 and discuss emergent relationship(s) with extant literature in section 4.5 of the thesis.

The third sub-question, "How is the socio-spatial order of the city influenced by neoliberalisation and what are the consequences for evicted slum dwellers", was in continuum of the previous question and included field work and empirical material collection and analysis. The research by then had revealed rejection of shelter rights of unpropertied citizens, cut-off date for compensatory shelter on eviction limited to 1976 and differentiated social order on property basis. Data of slums located in right of way and influence zones of neoliberal projects was collected and spatially analysed to reveal the manifestation of social inequality on property basis on spatial order of the city. To understand consequences of dispossession by neoliberal projects for evicted slums dwellers, iterative process involved multiple methods of data collection and simultaneous analysis of data. To capture official claims related to displacement and resettlement of unpropertied citizens, documents of neoliberal projects that caused displacement such as master plan of SRFD and relevant documents of Basic Services for Urban Poor (BSUP) program under which "eligible" families were resettled were collected and analysed. To understand consequences for displaced families I use Cernea's (2000b) impoverishment risks in IRR framework. I reinterpreted impoverishment risks and indicators to assess them for the specific context of Ahmedabad (as shown in Table 20 of chapter 5). To assess consequences for evicted unpropertied citizens, I conducted household survey of families in different stages of displacement to include those resettled on various BSUP sites, on the interim resettlement site and those that continued to reside on demolished sites. The sampling framework for the survey is described in Table 19 of chapter 5 . The 
survey was statistically analysed to describe the onset of multiple forms of impoverishment in displaced families. The findings also revealed a gap between official claims related to displacement and resettlement and actual practice by AMC. These gaps were corroborated by semi-structured interviews with leaders of displaced communities, NGO members, civil right activists, academicians and senior officials at various level in AMC, focus group discussions with displaced communities, field observations and documentary analysis of media reports, academic reports and official AMC notices to displacees at various stages of displacement.

To conclude, I began the research with a priori conceptual framework shown in Figure 9 of this chapter, which was progressively informed by empirical findings. The final, emergent conceptual framework from empirically grounded research is shown in figure 32 and described in section 6.2.4 of the thesis.

\subsection{Outline of the further content}

Chapters 1 and 2 described my motivation and the contextual and conceptual foundations for this research. The research is interpretive in the sense that I did not collect "facts" about decentralisation and neoliberalisation but rather tried to understand the situated meanings of stakeholders regarding these processes. The empirical core of the thesis is based on series of papers (chapter 3 to 5) two of which have been published in international peer reviewed journals and one of which is currently under review. The findings of these chapters are then synthesized (chapter 6) and used as a starting point for a subsequent examination of the importance of citizens' information rights in the current planning and development regime in Ahmedabad (chapter 7) and implications for governance (chapter 8). The relationships between the chapters are shown graphically in Figure 10.

Chapter 3 answers the first research question "How are (un)propertied citizens affected by decentralisation initiatives?"

Chapter 4 answers the second research question "How does neoliberalisation affect key socio-economic rights of unpropertied citizens and the social order of the city?"

Chapter $\mathbf{5}$ answers the third research question "How is the socio-spatial order of the city influenced by neoliberalisation and what are the consequences for the evicted slum dwellers?"

Chapter 6 synthesises the research sub questions and central question by progressively revising the initial conceptual framework.

Chapter 7 answers an additional question "Whether and how can information transparency catalyse participation of citizens in local 
governance?", an epilogue of sorts, inspired by the rather bleak response to the main question.

Chapter $\mathbf{8}$ discusses the implications of my research for urban governance in India, and reflects on shortcomings and future research directions.

\begin{tabular}{|c|c|}
\hline -Chapter 1 & $\begin{array}{l}\text { Understanding the issues and empirical } \\
\text { context }\end{array}$ \\
\hline -Chapter 2 & Theoretical framework and research strategy \\
\hline -Chapter 3 & $\begin{array}{l}\text { Consequences of decentralisation for different social } \\
\text { groups and social order of the city }\end{array}$ \\
\hline -Chapter 4 & $\begin{array}{l}\text { Consequences neoliberalisation for socio-economic } \\
\text { rights of the unpropertied citizens and social order of } \\
\text { the city }\end{array}$ \\
\hline - Chapter 5 & $\begin{array}{l}\text { Socio-spatial order of the city under neoliberalisation } \\
\text { and consequences for evicted slum dwellers }\end{array}$ \\
\hline - Chapter 6 & Synthesis \\
\hline -Chapter 7 & $\begin{array}{l}\text { Catalysing citizen participation through information } \\
\text { transparency? }\end{array}$ \\
\hline -Chapter 8 & Reflection and future directions \\
\hline
\end{tabular}

Figure 10: Thesis chapters and their relationship 


\section{Chapter 3}

Participatory local governance in Ahmedabad : invited, closed or claimed spaces for urban poor? ${ }^{1}$

\footnotetext{
${ }^{1}$ This chapter is based on Patel S, Sliuzas R, Georgiadou Y, 2016, "Participatory local governance in Asian cities: invited, closed or claimed spaces for urban poor? "

Environment \& Urbanization Asia 7 1-21 doi: 10.1177/0975425315619044, available online February 16, 2016
} 


\begin{abstract}
In the past two decades, many Asian countries, including India, have mandated participatory local governance through national statutes. Emerging research on Asian cities is showing that despite strong national mandates, the practice of participatory governance at local levels remains largely ineffective. Our research in Ahmedabad in India shows that while the State government policy's mandate for invited spaces for participation in local governance is weak compared to the national government's policy, the practice of the local government is even weaker leading to ineffective or closed participatory spaces. In absence of invited spaces, middle class citizens successfully use the executive wings at ward and zone levels and e-governance and $\mathrm{m}$-governance platforms to negotiate their needs, whereas the poor rely on elected representatives, but with limited success, resonating the experience of many cities in Asia. While in other cities of India the poor have successfully engaged with elected representatives through clientelism to negotiate their needs, in Ahmedabad this platform is also captured by elite middle class which has emerged as a larger, more influential and favoured electorate in neoliberal Ahmedabad. The poor mobilise to claim spaces of negotiation through judicial recourse from time to time, in response to closure of both invited and negotiating spaces, to negotiate their socio-economic rights. Claimed spaces are one-off, have shown mixed results and close upon the end of the judicial process rather than culminate into permanent invited spaces for participation
\end{abstract}

Keywords: participatory local governance, invited spaces, claimed spaces, closed spaces, slums, poor, exclusion 


\subsection{Introduction}

Since the onset of neoliberalism and globalisation in the past two decades, debates on the relation between the state, the markets and the citizens have centred on two processes: the process of moving "out from government" and the process of "moving down of government" bringing it closer to citizens through "decentralisation" and "participatory governance" (Pierre and Peters, 2000). The first process involves sharing of power by the government with civil society actors and private sector and the second process involves sharing of power from higher tiers with lower tiers of government (decentralisation) and further with participatory tiers in local government (participatory governance). The rationale for participatory governance is that it strengthens local democracy by increasing "spaces" for participation by citizens in local governance processes (Nainan and Baud, 2008, Cornwall and Gaventa, 2001, Devas, 2004) which in turn contributes to more viable and just policies and a positive impact on poverty, inequality and development processes (Coelho and Favareto, 2011).

Gaventa (2006) defines "spaces" in participatory governance as "opportunities, moments and channels where citizens can act to potentially influence policies, discourses, decisions and relationships which affect their lives and interests"(2006: 26). He proposes three types of participatory spaces which are dynamically related: closed, invited and claimed. In closed spaces citizens are not allowed any say in decisions taken by the state. Invited spaces, are those where the state offers citizens the possibility of participation in decision making processes and may be institutionalised and permanent or transient. In claimed, spaces citizens come together as autonomous agents to create opportunities to influence the state.

Of these, the invited spaces represent participatory governance and allow citizens to be "makers and shapers" rather than just "users and choosers" of services. Invited spaces provide a platform to them both as consumers of services as well as citizens with rights to shaping their cities (Baud and Nainan, 2008, Cornwall and Gaventa, 2001). Invited spaces are assumed to lead to more efficient delivery of services as decisions are made at levels in proximity to the source of citizen problems and to more accountability of government to the citizens. It is proposed that the higher the proximity of such spaces to the citizens the higher will be the responsiveness of the government (Crook and Manor, 1998).

Researchers have suggested that a national policy or statute mandating invited spaces in local governance is required for them to be meaningful (Parry et al., 1992). Further, researchers claim that such mandates should provide equal opportunity to all citizens to participate, should delegate clear functions, powers and financial autonomy to the invited spaces (deWit et al., 2008) and 
should allow participants in these spaces to be involved in all three areas of influence i.e. formulation, process of passing and implementation of public policies (Fung and Wright, 2003a).

Scholars who support participatory governance argue that it enhances proximity of local government to citizens and can match policies and service delivery with the actual needs of citizens (Cornwall and Coelho, 2007, Cornwall and Gaventa, 2001, Baud and deWit, 2009, Gaventa, 2006). They argue that participatory governance gives citizens the opportunity to participate in urban transformation, to negotiate their socio-economic rights and ensure their wellbeing. However, they caution that invited spaces are meaningful if they allow citizens to be "makers and shapers" rather than just "users and choosers" of services, implying that the spaces should provide a platform for citizens to participate in policy making rather than merely to negotiate their needs as service consumers (Baud and Nainan, 2008, Cornwall and Gaventa, 2001).

Scholars sceptical of decentralisation argue that participatory spaces are designed by the state to capture local elites and thus further disempower marginalized groups (Swyngedouw, 2005, Crook and Sverrisson, 2003a). They argue that local government may be reluctant to share substantive power with citizens on the grounds that citizens' interests may override interests of the city as a whole (Baud and deWit, 2009) or because of the neoliberal bias that democratic deliberation is inefficient (Hay and Jessop, 1995). Swyngedouw (2005) cautions that though participation may have a sympathetic ring, it may in fact be an attempt of the neoliberal state to confer tasks upon elite citizens under arrangements that are not democratic, non-transparent and fuzzy.

Swyngedouw (2005) proposes that, whereas formal democracy has clear rules and offers equal opportunity, if only to vote, in participatory governance participation itself can become contested and limited in terms of who can and or who will be allowed to participate. In essence there is a risk that invited spaces will be captured by local elites for their own interest, with an exclusionary effect on the marginalised and the urban poor (Kundu, 2011, Baud and Nainan, 2008, Teeffelen and Baud, 2011, Swyngedouw, 2005). Discussing the politics of participatory governance Coelho et al (2011) suggest that participatory governance has implications on the politics of decision making as it splinters the urban local polity into smaller neighbourhood based units, institutionalises powers of the new middle class leaders and legitimise exclusionary agendas of neighbourhood associations. In essence it paves way for a new politics of civil society and urban activism at the expense of elected bodies, representatives and urban poor. Through participatory spaces the middle class in Indian cities is increasingly emerging as a political agency with a political and moral leadership, spurring renewal, decongestion or 
beautification of cities as well as dispossession and dislocation of the urban poor (Deshpande, 2006, Ghertner, 2011).

When less powerful actors are thus excluded from invited spaces because of elite capture, Gaventa (2006) proposes that they mobilise for common concerns and claim spaces for themselves in governance which he refers to as "claimed" spaces. Gaventa (2006) suggests that claimed, closed and invited spaces exist in a dynamic relationship to one another, and are constantly opening and closing through struggles for legitimacy and resistance, cooptation and transformation. Closed spaces may seek to restore legitimacy by creating invited spaces and similarly invited spaces may be created as more autonomous people's movements attempt to use their own fora to claim engagement with the state.

The debates and advocacy for participatory governance and decentralisation in last two decades have led to their implementation by sixty three developing countries by 1980s (World Bank, 2000). In Asia, Philippines, Cambodia, Vietnam and India among others began to follow the global trend since 1990s.

Philippines introduced the Local Government Code (LGC) in 1991 to increase autonomy of local governments and participatory local governance. The LGC mandated participation through two invited spaces: Barangay Assemblies at ward level and Local Development Councils (LDCs) at city level. Researchers have shown that both these invited spaces are neither fully implemented nor functioning in all the cities of Philippines (Yilmaz and Venugopal, 2013). In Vietnam, participatory local governance and decentralisation were mandated in 1998 through Decree 29 termed as "The promulgation of regulations on the exercise of democracy in Communes." Decree 29 introduced commune people's council as an invited space allowing participation in four processes namely information, consultation, approval and supervision. However available evidence suggests an uneven pattern of implementation across the country attributed to the broad and unclear framework of Decree 29. Unclear responsibilities and insufficient devolution of decision making powers to commune people's councils have diluted their effectiveness in decision making (Mattner, 2004). In Cambodia participatory governance and decentralisation were institutionalised in 2001 through two laws: the Law on Election of Commune and the Law on Administration and Management of Communes. The laws mandated invited space for citizen participation in commune councils. Researchers argue that in reality power remains centralised at higher tiers of government rendering these spaces ineffective. Further, these spaces are argued to be indifferent to rights of the poor especially where a conflict with rich and big business occurs. In essence these spaces are often captured by local elites (Alicias, 2011). 
The Government of India (GoI) mandated participatory governance and decentralisation first in 1992 through the 74 $4^{\text {th }}$ Constitutional Amendment Act ( $74^{\text {th }}$ CAA) and further in 2005 through the Community Participation Law (CPL) under Jawaharlal Nehru National Urban Renewal Mission (JNNURM). The 74th CAA proposed devolution of power from state to local governments and mandated local governments with population more than 300,000 to form one more tier i.e. Ward Committee (WC) as a participatory space wherein elected councillors, administrative officers and citizen groups would work together. However states took a long time to ratify this legislation and setting the processes in motion in their Urban Local Bodies (ULB). Many but not all cities created WCs and there were vast differences across cities in terms of WC's composition, proximity to citizens, functions, powers and resources (deWit et al., 2008). Consequently in 2005 , the political party that enacted $74^{\text {th }}$ CAA reinforced and mandated participatory governance and decentralisation processes through CPL as a reform at the state and local levels under JNNURM.

Under JNNURM, the national government proposed a model CPL for state governments to emulate. The model CPL's proclaimed objective was to "deepen democracy, facilitate efficiency and socio-economic growth and promote propoor initiatives" (Government of India, 2006d: 2). Under CPL a minimum of three tiers of decision making were mandated in a ULB; the city level, the WC level, and the Area Sabha (AS) level with invited participatory spaces for citizens at lower two levels. States had to either enact a separate CPL on lines of the model CPL given by the national government or make appropriate amendments to their existing municipal laws to clearly define composition, proximity criteria, functions and powers and funding sources of the two participatory tiers (Government of India, 2006d). The local governments then had to implement these tiers as per the statute enacted by state government. To ensure compliance by state and local government, a tripartite Memorandum of Agreement (MoA) between national, state and local government was signed. Non-compliance with agreed conditions in the MoA would lead to curtailment of grants from the national government.

Both WCs and ASs were aimed to act as platforms of neighbourhood governance and increase proximity between elected representatives and citizens through invited spaces for citizen participation (Sivaramakrishnan, 2000). By2010, both $74^{\text {th }}$ CAA and the CPL remain ratified and implemented to different degrees by state governments (Baud and Nainan, 2008, TERI, 2010, deWit et al., 2008). The research on practice of these initiatives remains limited to a few states which were early ratifiers like West Bengal, Kerala, Maharashtra, Madhya Pradesh and Karnataka. The State of Gujarat ratified 74th CAA in 1997 but institutionalised WCs only in 2007 and ASs in 2012. As a late rejoinder, the experience of participatory governance through invited spaces in Gujarat remains largely unexplored except for a few government sponsored 
studies by TERI (2010) and Grant Thornton (2011). This paper addresses this empirical research gap.

The research attempts to validate Gaventa's (2006) spaces for participation in the power cube by inquiring how the spaces are created, on what terms and serve whose interests in context of Ahmedabad in India. A particular focus is on the extent to which the two predominant social groups, the propertied middle class and the unpropertied poor, are able to negotiate their socioeconomic rights through such spaces. The four specific questions are as follows:

- How are participatory spaces created locally under the mandates of national and state governments?

- What opportunities do participatory spaces offer to the two social groups to deliberate on ward planning and budgeting process and to negotiate their rights?

- How do the two social groups attempt to negotiate their rights and whose interests are served?

- Is there a neoliberal bias in the participatory governance process?

\subsection{Methods}

Mixed methods were used to collect and analyse primary and secondary data. The field work for the research was undertaken from May 2014 till February 2015. To understand the gap between the mandate of national government and implementation by the State government, related secondary data was collected and critically analysed. Secondary data included JNNURM documents such as the CPL Primer, the MoA between the three governments, the commitment by the State government for implementation of CPL in the MoA and the State government's statutes related to formation of WCs and ASs. The findings on gaps were corroborated by semi-structured interviews of two key officials from Gujarat's urban development and urban housing department, three key officials in Ahmedabad Municipal Corporation (AMC), members of three key Non-Governmental Organisations (NGOs) and six members of academia engaged in various aspects of participatory governance and slums in Ahmedabad (Figure 11). 


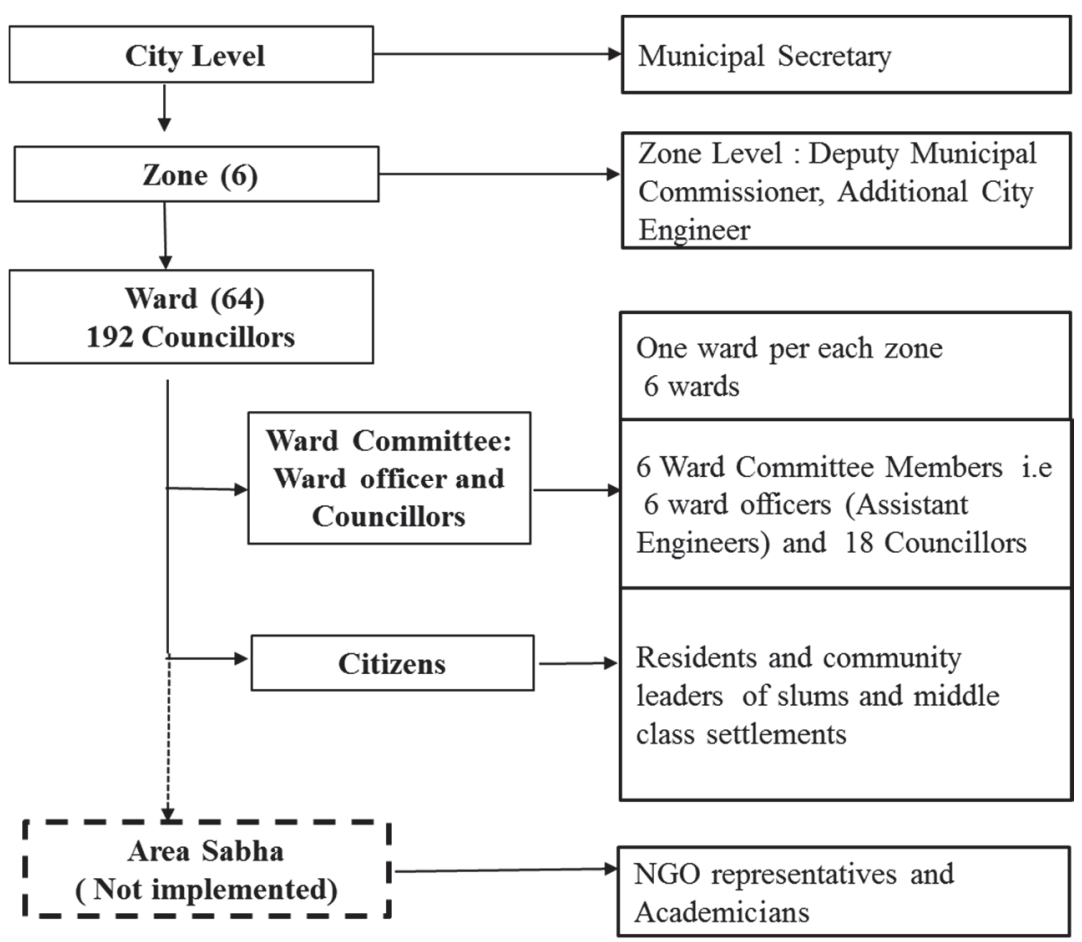

Figure 11: Distribution of semi-structured interviews of key stakeholders in Ahmedabad

Source: Compiled by authors

To understand the implementation of the State mandate at the local level secondary and primary data were collected and analysed. Secondary data included the resolutions passed by the AMC for the formation of WCs and ASs, AMC's annual budget documents from 2012 to 2015, Census 2011's population data including ward population and marginalised group composition, and data on utilisation pattern of individual budgets of councillors of selected wards. Six wards, one from each zone were selected to get the perspectives of all the key stakeholders. To capture official claims related to community participation in WCs and budgeting processes, semi-structured interviews of AMC officials and councillors were undertaken. They included nine executive officials including municipal secretary at city level, deputy municipal commissioner and additional city engineer at zone level and six assistant engineers (also ward officers) at ward level. Eighteen councillors from various wards were interviewed to capture their response to different citizen groups including those from wards with low and high composition of marginalised population and those from opposition parties. Twelve residents from middle class and twelve slum community leaders were interviewed to understand the efforts to claim spaces for participation by different social groups. Two NGOs and four academicians 
working with slum communities were interviewed to corroborate the claims of ward officers and councillors.

\subsection{Results and discussion}

This section is arranged in three subsections, each discussing one subquestion.

\subsubsection{Implementation of national government mandate by the state government}

In this section we assess whether the Government of Gujarat's (GoG) rules for WCs and ASs follow the national mandate in terms of meaningful opportunities to citizens groups and particularly the poor to participate in local governance.

\subsubsection{Mandate for Ward Committees in Gujarat}

The first mandate for participatory governance was given by national government under $74^{\text {th }}$ CAA by provision of WCs in ULBs with "nomination of persons having special knowledge or experience in municipal administration"(Government of India, 1992). The WCs could thus have members from various citizens groups and provide a platform for bringing the local government closer to the people (Singh and Maitra, 2001). The74 $4^{\text {th }}$ CAA allowed the states to decide the extent of devolution of functions, powers and fiscal resources to WCs but with the corollary that all three would be devolved.

Many states, including Gujarat, had not passed rules related to WC as per the provisions of $74^{\text {th }}$ CAA. Hence under JNNURM participatory governance was reemphasised and mandated by the national government through the provision of CPL as a mandatory reform for the state governments. Consequently, though GoG had ratified $74^{\text {th }}$ CAA in 1993, it sanctioned the rules for formation of WCs only in 2007 under provision of CPL reform of JNNURM and after signing a MoA with national government in 2006 committing to this and other reforms (Government of India, 2006a). The GoG rules are titled "Gujarat Municipal Corporation's Ward Committees Functions, Duties, Territorial Areas and Procedure for Transaction of Business, Rules 2007".

We assess the functions, powers, resources and composition of a WC under the rules. First, the rules limit the powers of WCs by making them to "be advisory in nature" (Government of Gujarat, 2007: 2) and assigning them following functions :

- Collect details of deficiencies in essential services by the Municipal Corporation, assess the requirement of development works to be undertaken and make recommendations to the standing committee for development works

- Review complaints and guide the administration in speedy disposal of complaints 
- Review implementation of schemes in slums and programs related to poverty eradication

- Seek co-operation of citizens and NGOs in solid waste management and in making the city clean and beautiful

- Extend co-operation in the recovery of property tax

- Create awareness among citizens towards duties and responsibilities.

The list indicates that a WC is limited in functions and powers and is to only serve as a platform for advising, reviewing, seeking cooperation and extending cooperation to citizens and Municipal Corporation. It is not assigned independent power in formulation, passing and implementation of projects at ward level. Further, in Gujarat WCs have not been allotted any resources and thus have no financial autonomy. By contrast a few other states, such as Maharashtra and Tamil Nadu, have devolved substantial powers and fiscal resources to WCs and have empowered them to sanction works up to INR 500,000 (USD 8,012 ${ }^{1}$ ) and INR 1,000,000 (USD 16,025) respectively (Singh and Maitra, 2001). This is also done in Kerala, West Bengal and Madhya Pradesh (deWit et al., 2008).

Finally, Gujarat's rules prescribe a WC to be composed of three councillors and one ward officer and excludes provision for citizen participation, unlike states like Maharashtra, Karnataka, West Bengal and Kerala whose rules allow cooptation of three, seven, fourteen and fifty citizen members respectively including representatives of urban poor communities (deWit et al., 2008, TERI, 2010). In Kerala, which is considered a national good practice, a WC has large and inclusive participation with 15 persons from registered resident welfare associations, 20 from registered poor neighbourhood groups, one nominated by each political party represented in the council, heads of all recognized educational institutions in the ward and 20 nominated jointly by the chairperson and councillor (Administrative Staff College India, 2011). Thus both middle class and poor community members have equal representation in WCs in Kerala. The disposition to empower all classes of citizens in local governance in Kerala and also in West Bengal could be attributable to communism as a deeply rooted social, political, and economic ideology there whereas the indisposition in Gujarat could be attributable to the deepening neoliberalism and right wing politics in local politics which tend to give patronage to the local elites (Desai, 2006).

\subsubsection{Mandate for Area Sabhas in Gujarat}

The objective of national government's CPL and AS mandate was to institutionalise inclusive participatory governance through representation of all groups of a polling booth (of approximately 1500 to 4000 population) (Figure 12). The CPL primer mandated clear devolution of functions, powers and resources (Government of India, 2006d) but allowed the state governments to 
decide the extent and nature of the three as well as the exact composition of the invited spaces.

For constitution of AS, GoG enacted rules in February 2012, three years later than the agreed timeline of 2009 in the MoA with the national government.The rules are titled "Functions, Duties, Territorial Areas and Procedure for Transaction of Business of Area Sabhas". Though outside the scope of this research, it is instructive to note that despite this delay and breach of conditions of MoA (Government of India, 2006b), the national government continued releasing subsequent grant instalments to GoG and AMC for infrastructure development. This is an indication of lack of seriousness of all tiers of government related to participatory governance.

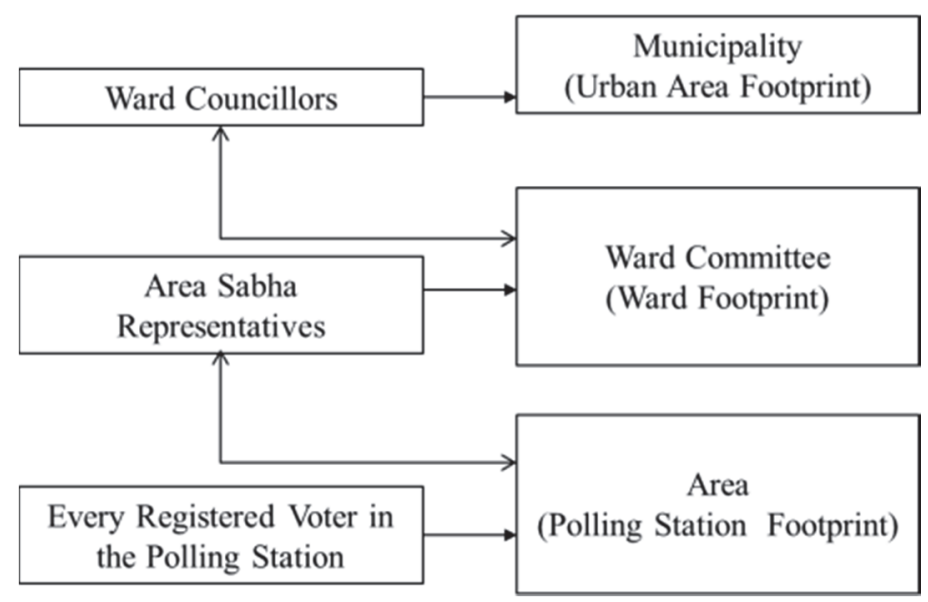

Figure 12: Proposed structure by GoI for participatory platforms under CPL reform primer of JNNURM

Source: JNNURM CPL Primer document, 2006

This is reiterated by the GoG rules which limit the functions and powers of an AS to being only advisory by stating "Ward committees shall prepare their proposals/suggestions for the annual budget for respective ward in consultation with area sabha" (Government of Gujarat, $2012: 2$ ). Other than this statement, there is no mention of functions, powers and resources or financial autonomy to this invited space.

In terms of representation ratio and proximity to citizens, GoG rules recommend that each ward be divided into three ASs, irrespective of size and population of the ward. As per the municipal statute of Gujarat state, three councillors are elected from each ward in a ULB. Hence each ward is pragmatically distributed in three ASs without much consideration to proximity 
of this space to citizens such that one councillor chairs each AS. However, in metropolitan cities with large ward populations such as Ahmedabad, such a constitution may not deepen democracy as representation ratio of an AS will be an average of 29,000 i.e. more than ten times the "polling booth footprint" of 1500 to 4000 mandated by the GoI in the CPL.

Concerning composition of an AS, GoG rules recommend "Municipal corporation shall appoint members of area sabhas from among the eminent citizens including retired government officials, ex-councillors, teachers, NGOs from literary and social fields, urban planners and architects" (Government of Gujarat, 2012:2). Though promoting pro-poor initiatives through representation of poor communities was the key objective of CPL, slum dwellers or their leaders are not included in the list of "eminent citizens" invited to this space. The rule therefore serves interests of the elite and will lead to their capture of this space. This lacuna was also highlighted by GoI's appraisal agency for JNNURM, Deloittee Touche Tohmatsu India (2013) but evidently it was not taken cognisance of by GoI as there is no record of amendment in the GoG rules or retributionary action by GoI. Thus GoG rules for ASs deviate from mandates of CPL by GoI as they do not devolve substantive functions powers and financial autonomy, limit representation by mandating three ASs in a ward and promote elite capture of this space.

Review of the rules of GoG for both WC and AS indicates a clear reduction in the mandates by the State government out of the envisaged mandates provided by national government under both the $74^{\text {th }}$ CAA and JNNURM'S CPL. A large representation ratio between citizens and nominated representatives at both levels, absent and differentiated citizen participation that excludes urban poor members, absence of selection process criteria for citizens, limited functions and powers and no financial autonomy clearly indicate the reluctance of GoG in sharing power with these invited spaces and providing meaningful opportunities to citizens to participate in local governance processes.

While "elite and eminent" citizens have been accommodated in the GoG rules for invited space of AS, the urban poor have been excluded which may have implications on their quality of life understood as the extent to which their basic needs and rights are reflected in the activities carried out in this space (Baud and Nainan, 2008). This exclusion becomes more problematic in the context of Ahmedabad as slum dwellers comprise 26 per cent of population in the city, ranging from 14 per cent in east zone to 40 per cent in central zone (Ahmedabad Municipal Corporation, 2007:73). As access to the two invited spaces is denied to them by the GoG rules, we inquire if and how do the unpropertied poor manage to negotiate or claim socio-economic rights. 


\subsubsection{Implementation of participatory governance by Ahmedabad Municipal Corporation}

In this section, we discuss how participatory governance has been locally implemented by AMC under limited mandates of GoG's rules for WC and AS.

A local government in India has political representation by councillors elected at ward level since the $74^{\text {th }}$ CAA in 1992 . AMC thus consists of both political and executive wings. The executive wing is headed by municipal commissioner and the political wing by a mayor elected from the councillors. For administrative purposes AMC is divided into 6 zones and 64 wards below the zones. Three councillors are elected from each ward and the 192 councillors including the mayor form the General Board which is the final decision making body (Figure 3). Below this is the Standing Committee comprising of both political and executive members including the municipal commissioner and below it are fourteen sector committees. The Standing Committee functions as an advisory body to the General Board and constitutes of 12 councillors selected on prorata basis from every political party by the General Board (one from 16 councillors of a party). Since the General Board at present has 151 councillors from the ruling party BJP, 38 from the opposition party Congress and 3 independents, the standing committee has 9 members from BJP and 3 members from Congress. As BJP has the overwhelming majority in the general board since ten years or last two terms, councillors from the opposition party and their wards tend to be ignored in terms of budget allocation. This concern was highlighted by a former mayor from the Congress party who said "..councillors (from BJP) politicising things and ignoring areas that voted the opposition party mar the very objective of having a ward committee" (Siddiqui, 2009). The General Board meets on a monthly basis, Standing Committee on a weekly basis and sector committees meet every 15 days. The agenda of meetings is to finalise and sanction project proposals submitted by the municipal commissioner of value above INR 500,000.

The executive wing functions at the city, zone and ward levels. Its task is to implement a wide range of services and projects approved by the general board. The executive heads of a zone and a ward are the deputy municipal commissioner and assistant city engineer respectively. The annual budget formulation and allocation after approval by the General Board is done at the zone level. The zone officers invite budget estimates from their respective wards as well as sector committees, adjust the estimates as deemed appropriate and finalise the zone budget for recommendation to the municipal commissioner who aggregates budgets of all six zones, formulates the city budget and presents to the standing committee which amends it as deemed appropriate and presents to the board for the final approval. The budget approved by the board is then allotted to the zones which retains the funds for zonal works and allots the funds for ward works to the WCs. Despite 
decentralisation mandates, the budget finalisation power remains at the zone level. This is attributed by an academician "to the clientelistic political system wherein the zonal executives and political party chief are reluctant to yield their discretion over finalisation of fiscal resources as doing so runs them the risk of disenchanting the middle class elite who expect to have privileged access to public resources in exchange for their political support." 2 The deputy commissioner's response to this concern was that "this is in the interest of the city as a whole otherwise the local problems and budgets may take over the city problems and democratic deliberation will delay fast track development of projects and delivery to citizens." ${ }^{3}$

\subsubsection{Ward Committees as invited spaces for participation in Ahmedabad}

Pursuant to passing of GoG's rules for WCs, AMC passed the resolution for their formation in 2007 as per the stipulations of GOG rules in terms of functions, powers, resources and composition. Our research indicates that WCs have been formed in all the wards of Ahmedabad but are ineffective as participatory spaces.

First they are exclusionary in terms of composition and functioning. This is partly because the GoG rules do not mandate representation of citizens in WCs. Citizen exclusion is further deepened by denial of access for interested citizens to routine decision-making processes such as monthly meetings where ward development works are formulated and reviewed or to the meeting minutes wherein the decisions made in the meetings are stated. The lead author was denied permission by two ward officers to attend a monthly meeting on the grounds that "often confidential matters related to budgeting are discussed." NGOs are also excluded from WC's decision making processes. A NGO member explained that this was "because of resistance from councillors who see us as competitors in power and legitimacy over their constituent voters." 5 Such exclusion of citizens and NGOs stands in contrast to inclusive practices of WCs in cities of Kerala and West Bengal etc. where meetings and related documents are made open to the citizens (TERI, 2010) and in Mumbai where WCs successfully engage with NGOs, even if only as advisory members (Baud and Nainan, 2008). 


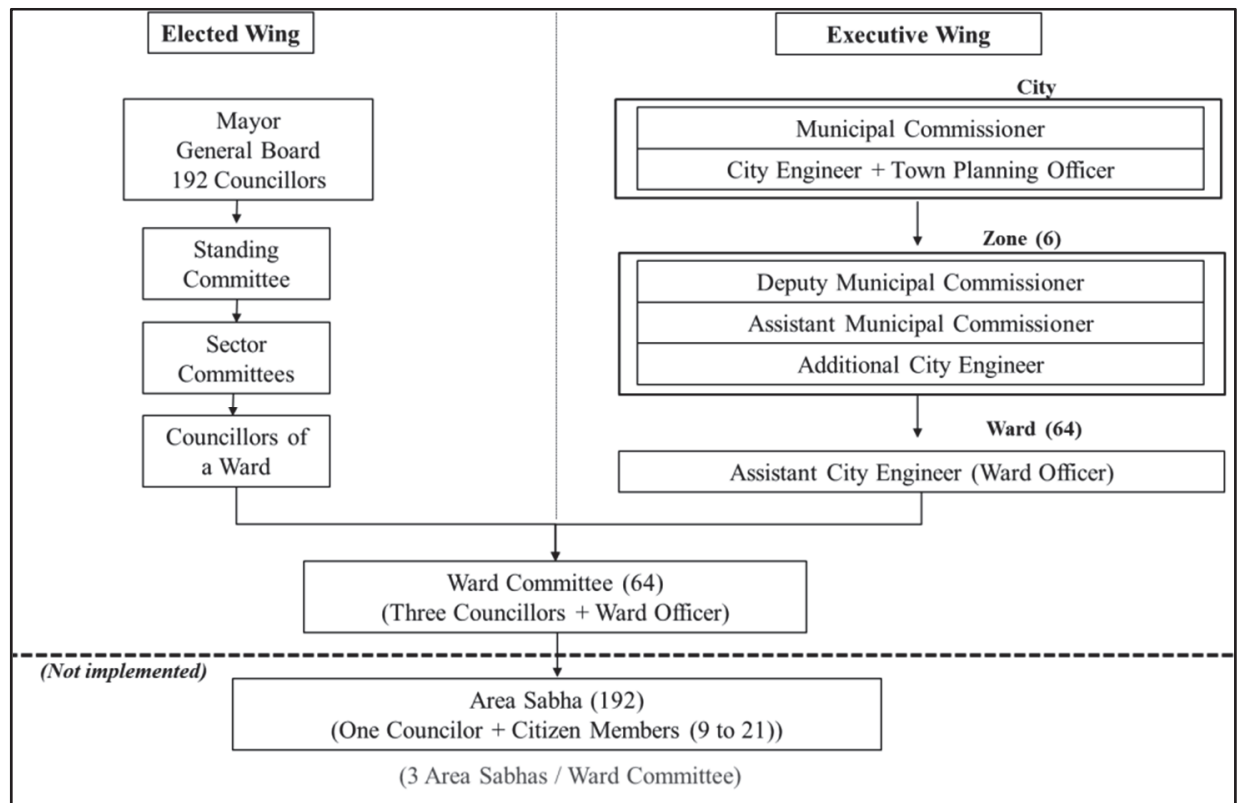

Figure 13: AMC Structure after the mandate for ward committees and area

Source: Compiled by authors sabhas

Second, WCs are not in proximity to citizens and hence to the source of their problems. WCs represent an average of 97,858 populations with a maximum of 295,000 and a minimum of 33,829 populations. Such a high representation ratio and increased distance from citizens' reduces responsiveness of WCs to their needs and grievances. Among the two major social groups i.e the poor and the middle class, the reduced proximity appears to cause more adverse implications on the well-being of the poor. The middle class has good access to basic services and their grievances mainly pertain to minor repairs or upgrade for which they resort to multiple platforms. As explained by one respondent " $I$ and my neighbours use AMC's toll-free phone number ( $m$ governance platform) or internet-based complaint registration portal (egovernance platform) and only if the two don't yield a result we contact the ward officer or a higher officer at the zone level." All respondents from this class expressed "satisfactory responsiveness from all these platforms." 6

On the other hand slum dwellers have very limited basic services and hence their complaints pertain to development works for the slum or for their individual dwelling for which they have approach the councillors through the leader of their Community Based Organisation (CBO). One respondent explained that "Councillor(s) is the only platform available to us to negotiate our needs. We approach him as a community rather than individually in expectation of eliciting more responsiveness. But as he is busy, access is 
difficult and response remains delayed or absent except during election time when the response is prompt." ${ }^{\prime 7}$ Eighty per cent of respondents in this group expressed unawareness of $\mathrm{m}$-governance and e-governance platforms for grievance redressal. ${ }^{8}$ It is clear that for the poor, proximity to councillors is a critical factor for better responsiveness to their needs and that alternative forms of grievance redressals used successfully by the middle class have not reached them yet resulting in a e-based divide, also shown by Teeffelen and Baud (2011) in case of Hubli Dharwad.

Third, constituted under the GoG rules which devolve substantial functions, powers and resources, WCs in Ahmedabad are limited to being only advisory with limited power which have left them at the mercy of political power game and manipulation as in other cities like Mumbai (Baud and Nainan, 2008). As WCs do not have fiscal resources, they only formulate development works, make budget estimates and recommend these to the zone office. The budget may get accepted or may get amended as deemed appropriate by zone authorities and the political party chief of the zone.

A review of AMC's annual budget of last three years (Table 7) indicates that AMC allots the wards a paltry portion of the total budget i.e less than $5.3 \%$ of the total municipal budget (Ahmedabad Municipal Corporation, 2012, Ahmedabad Municipal Corporation, 2013, Ahmedabad Municipal Corporation, 2014) and this percentage has been progressively decreasing, indicating a tendency of AMC to undermine WCs. This stance is in contrast to practice of other cities such as Hyderabad where $20 \%$ of total municipal budget is allotted to wards so that WCs can perform substantive functions entrusted to them (Administrative Staff College India, 2011).

Table 7: Details of ward budget as percentage of total municipal budget in last three years

\begin{tabular}{|c|c|c|c|c|c|c|}
\hline \multirow[t]{2}{*}{ Zone } & \multicolumn{6}{|c|}{ Total Ward Budget (INR Millions) } \\
\hline & $\begin{array}{l}\text { Year } \\
2012- \\
2013\end{array}$ & $\begin{array}{l}\text { Percentage } \\
\text { of Municipal } \\
\text { Budget }\end{array}$ & $\begin{array}{l}\text { Year } \\
2013- \\
2014\end{array}$ & $\begin{array}{l}\text { Percentage } \\
\text { of Municipal } \\
\text { Budget }\end{array}$ & $\begin{array}{l}\text { Year } \\
2014- \\
2015\end{array}$ & $\begin{array}{l}\text { Percentage } \\
\text { of Municipal } \\
\text { Budget }\end{array}$ \\
\hline $\begin{array}{l}\text { Central Zone } \\
\text { Wards }\end{array}$ & 381 & & 347 & & 248 & \\
\hline East Zone Wards & 503 & & 298 & & 434 & \\
\hline West Zone Wards & 247 & & 297 & & 345 & \\
\hline North Zone Wards & 414 & & 420 & & 383 & \\
\hline South Zone Wards & 322 & & 494 & & 433 & \\
\hline $\begin{array}{l}\text { New West Zone } \\
\text { Wards }\end{array}$ & 505 & & 599 & & 508 & \\
\hline Total Wards Budget & 2372 & & 2455 & & 2350 & \\
\hline $\begin{array}{l}\text { Total Municipal } \\
\text { Budget }\end{array}$ & 45110 & $5.26 \%$ & 49510 & $4.96 \%$ & 53010 & $4.43 \%$ \\
\hline $\begin{array}{l}\text { Total Revenue } \\
\text { Budget }\end{array}$ & 19041 & $12.46 \%$ & 22920 & $10.71 \%$ & 24730 & $9.50 \%$ \\
\hline
\end{tabular}

Source: Ahmedabad Municipal Corporation Budgets 
An equity based budgeting approach would mean high per capita budget for wards with high composition of poor and marginalised groups i.e Scheduled Caste (SC) and Scheduled Tribe (ST) households. However discussions with ward officers and councillors reveal that budgeting in Ahmedabad is a political process that depends on complex power relations of ward councillors with the zonal political party chief and of the ward officer with the deputy municipal commissioner. ${ }^{9}$ This is also corroborated by analysis of last three years' budgets (Figure14) which shows that the per capita ward budget does not relate to the composition of marginalised group in the ward. The analysis also shows that many of the top ten wards in terms of composition of marginalised groups have been allotted far below average budget per capita, much to their detriment (Table 8).

Centralisation of power and budget decisions at zone level have implications on slum dwellers as their access is limited only to the ward councillors and does not extend to zone officials or the zonal political party chief. This was corroborated by a slum leader from ward 57 which has consistently received low per capita budget in last three years. He explained that "we can only access our councillor to negotiate our needs for development works but we meet with mixed response because final decisions are taken at the zone level where our councillor is not always able to wield influence."

Table 8: Per capita ward budget of top 10 wards in terms of marginalised population composition (SC and ST as \% of ward population)

\begin{tabular}{|l|l|l|l|l|l|}
\hline $\begin{array}{l}\text { Ward } \\
\text { Number }\end{array}$ & $\begin{array}{l}\text { Ward } \\
\text { Population }\end{array}$ & $\begin{array}{l}\text { Percentage } \\
\text { of SC \& ST } \\
\text { population }\end{array}$ & \multicolumn{4}{l}{ Ward budget per capita (INR/person) } \\
\hline & & & $\mathbf{2 0 1 2 - 2 0 1 3}$ & $\mathbf{2 0 1 3 - 2 0 1 4}$ & $\mathbf{2 0 1 4 - 2 0 1 5}$ \\
\hline 30 & 70015 & 80 & 560 & 631 & 597 \\
\hline 39 & 81636 & 78 & 184 & 408 & 245 \\
\hline 14 & 75687 & 77 & 492 & 408 & 325 \\
\hline 18 & 64713 & 69 & 507 & 556 & 525 \\
\hline 38 & 67110 & 67 & 636 & 574 & 456 \\
\hline 25 & 89953 & 62 & 765 & 843 & 561 \\
\hline 57 & 96266 & 57 & 346 & 347 & 249 \\
\hline 33 & 114146 & 57 & 297 & 293 & 258 \\
\hline 32 & 80638 & 53 & 308 & 429 & 397 \\
\hline 15 & 68566 & 49 & 456 & 384 & 343 \\
\hline $\begin{array}{l}\text { Average per capita ward budget allocation (of } \\
192 \text { wards) }\end{array}$ & 453 & 480 & 436 \\
\hline $\begin{array}{l}\text { Maximum per capita ward budget allocation } \\
\text { (of } 192 \text { wards) }\end{array}$ & 1667 & 1716 & 1558 \\
\hline
\end{tabular}

Source: Ahmedabad Municipal Corporation Budgets 


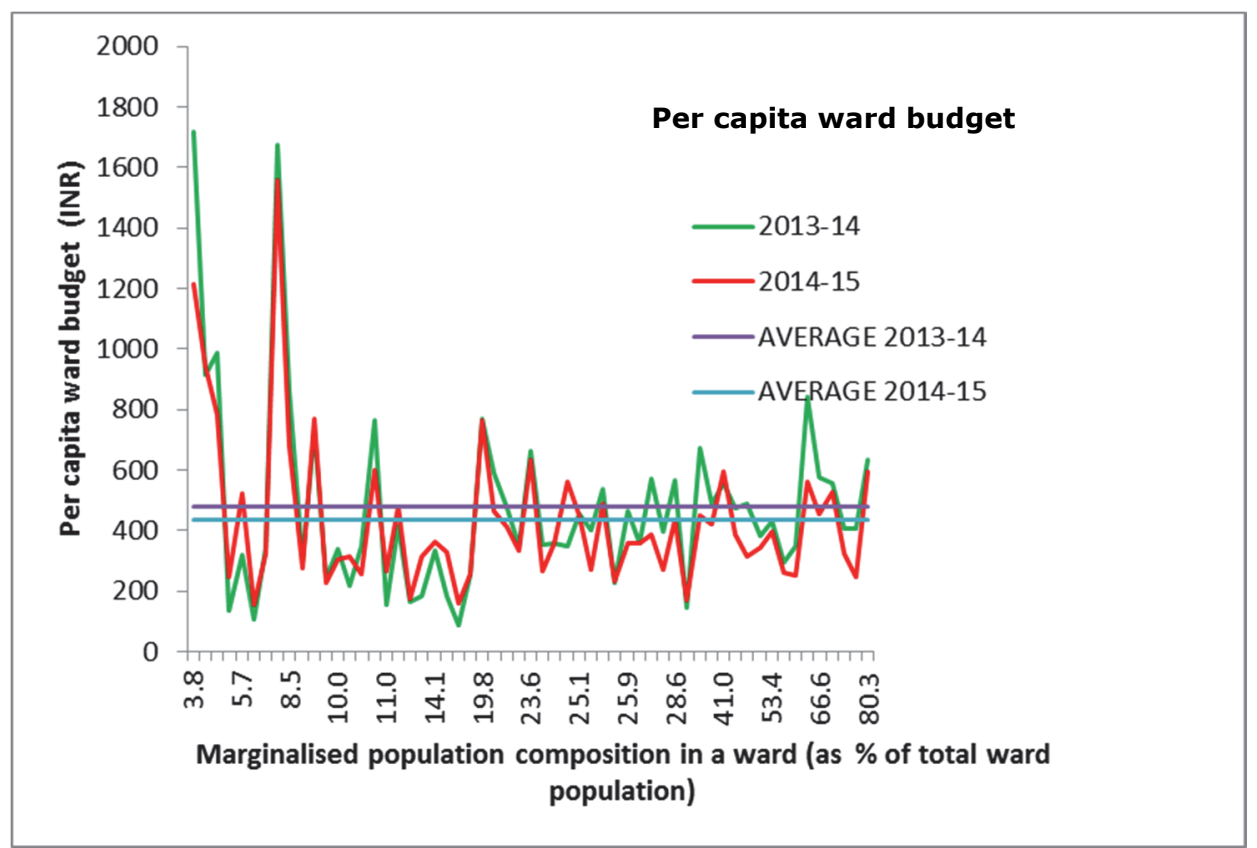

Figure 14: Relationship between marginalised population composition in a ward (as \% of ward population) and per capita ward budget in 2013 and 2014 budgets

Source: Ahmedabad Municipal Corporation Budgets

There is also a limitation of scope and nature of development works allowed by AMC at ward level. Because of budget limitations the scope is limited to repair and upgrade and excludes new development work. The nature of work allowed involves four rigidly specified categories: roads and footpaths, water supply networks, drainage networks, and public buildings such as municipal schools, urban health centres etc. As upgrade or new development works in slums are not specified as admissible category, the related requests by slum dwellers are denied by the ward officer on the grounds "that there is no provision for the category in the ward budget and that such projects fall in purview of zones." 10

\subsubsection{Area Sabhas and creation of negotiation spaces in Ahmedabad} Pursuant to GoG's rules for formation of ASs in February 2012 AMC passed a resolution for their formation in March 2012. Our research shows that at the time of field work in February 2015 ASs were not formed in any ward. In fact, when asked, one ward officer asked the lead author "to explain the meaning of the term !"11 When questioned about their absence, the municipal secretary responded that "the provision of three elected representatives in each ward instead of the usual one in other cities, offers an adequate representation of various citizen groups' interests and negates the need for an area sabha."12 
One ward officer claimed that "ward officers and councillors regularly meet citizens and are available for receiving complaints and requests, which negates the need for an AS." The claim was countered by an academician who said "three councillors per ward cannot be accepted in lieu of an AS since it implies an average population of 29,000 per councillor in Ahmedabad whereas an AS was intended at a much lower threshold of a polling booth population of 1500 to 4000 to deepen the participation.. AMC is not serious about these spaces as it deems democratic deliberation to be a waste of time and inefficient." ${ }^{13}$

It is evident that the state mandate on empowerment of both the invited spaces for participation, WC and AS, is weak and the practice of AMC is even weaker. This gap has caused more adverse implications on the quality of life of the poor than on the life of the middle class. While AS is not formed in any ward, WCs are formed but function with severe constraints and do not offer invited spaces for participation to citizens. Thus the citizens, both middle class and poor are denied the envisaged opportunity to be "makers and shapers" or having a voice in shaping their cities. But as "users and choosers" or as consumers of services the middle class rely on and succeed in negotiating their needs with executive officials at ward and zone level as well as through egovernance and $\mathrm{m}$-governance platforms. In absence of invited spaces, for the poor, the councillor is the only accessible platform for negotiating their needs as consumers but there also they meet with limited success. This dependence also opens the scope for clientelism as found by Teeffelen and Baud (2011) in case of Hubli Dharwad.

\subsubsection{Consequences of denied "invited spaces" on the poor and creation of one-off "claimed spaces"}

The discretionary budget of INR 17 million available to each councillor in Ahmedabad, irrespect3.ive of ward population, is the only platform where councillors can take decisions independent of other influences and offers a negotiation opportunity to citizens as consumers, even if a small one in terms of value. As this platform usually works on clientelism (Teeffelen and Baud, 2011), the councillor will tend to spend this budget on the social group which constitutes the larger portion of electorate, at least in the run-up years to the election. Review of allocation of individual budgets of six councillors, three from the ruling party and three from the opposition party indicates a contradictory behaviour and a sharp bias towards middle class neighbourhoods (Table 9). Budget for 2013-14 was analysed as the municipal election is scheduled in end of 2015. From their individual budgets the six councillors have spent between 0 to 25 percent on poor neighbourhoods and 44 to $75 \%$ on middle class neighbourhoods. This indicates an elite capture of this platform also and contradicts the view that there is pro-poor populist stance in case of different power bases i.e. from the opposition party (Crook and Sverrisson, 2003b) or in run-up years to an election. Though this is the only platform where the poor 
can negotiate their rights to basic services, it obviously offers limited scope and response.

Table 9: Individual discretionary annual budget of councillors from different parties spent on poor versus middle class neighbourhoods in 2013-14

\begin{tabular}{|l|l|l|l|l|}
\hline \multicolumn{4}{|l|}{$\begin{array}{l}\text { For poor \& low income } \\
\text { neighbourhoods }\end{array}$} & \multicolumn{3}{|l|}{$\begin{array}{l}\text { For middle income } \\
\text { neighbourhoods }\end{array}$} \\
\hline & $\begin{array}{l}\text { Budget } \\
\text { Amount } \\
\text { spent (INR) }\end{array}$ & $\begin{array}{l}\text { Amount } \\
\text { spent as '\% } \\
\text { of total } \\
\text { individual } \\
\text { budget (\%) }\end{array}$ & $\begin{array}{l}\text { Budget } \\
\text { Amount } \\
\text { spent } \\
\text { (INR) }\end{array}$ & $\begin{array}{l}\text { Amount } \\
\text { spent as '\% } \\
\text { of total } \\
\text { individual } \\
\text { budget (\%) }\end{array}$ \\
\hline Councillor 1 (Ruling party, BJP) & 310000 & $17 \%$ & 1274500 & $68 \%$ \\
\hline Councillor 2 (Ruling party, BJP) & 267000 & $14 \%$ & 1363000 & $73 \%$ \\
\hline Councillor 3 (Ruling party, BJP) & 460000 & $25 \%$ & 660000 & $35 \%$ \\
\hline $\begin{array}{l}\text { Councillor 4 (Opposition Party, } \\
\text { Congress) }\end{array}$ & 305800 & $16 \%$ & 827000 & $44 \%$ \\
\hline $\begin{array}{l}\text { Councillor 5 (Opposition Party, } \\
\text { Congress) }\end{array}$ & 153200 & $8 \%$ & 1124000 & $60 \%$ \\
\hline $\begin{array}{l}\text { Councillor 6 (Opposition Party, } \\
\text { Congress) }\end{array}$ & 0 & $0 \%$ & 1400000 & $75 \%$ \\
\hline
\end{tabular}

Source: Discretionary individual budget and utilisation sheets from councillors

Major development works in the settlements of the poor and marginalised groups, as reflected in the Annexure B (locally called "Patrak B") of the municipal budget are formulated, budgeted and implemented at central or zone level where there is no formal space for citizen participation. At the city level, from 2012 to 2015, the pro-poor budget for slum upgrading and similar works accounted for a paltry 3 per cent to 6.8 per cent of the total municipal budget (Table 10) even though the slum dwellers account for 26 per cent of population in the city (Ahmedabad Municipal Corporation, 2007:73) whereas the balance of the budget is for beautification and developmental works favouring the middle class. This grossly disproportionate allocation results from middle class activism for beautification and developmental projects and AMC's acquiescence (D’Monte, 2015, Desai, 2006).

The pro-poor budget includes capital works such as construction of new housing for urban poor, individual toilets and community toilets, urban health centres and crèche, development of drainage networks, street lights and roads in slums, night shelters for pavement dwellers etc. Such works are formulated, budgeted and implemented at the zone or city level and within the ambit of a national, state or local government supported program. In most programs provision for poor community participation is either absent or is mediated by NGOs or is tokenistic in nature (Mahadevia, 2014). For example in a major 
program, Basic Services for Urban Poor (BSUP), where INR 5000 million was invested to construct dwelling units for slum dwellers on new sites, the slum community was excluded from all stages of implementation as the program guidelines did not mandate participation. The consequent lack of understanding of their needs by AMC, led to further impoverishment of the poor in the new housing sites as shown by Patel et al (2015). They have shown multiple forms of impoverishment of displaced urban poor resettled on unsuitable sites such as loss of employment, loss of access to social amenities, health risks including increased mortality and food insecurity, marginalisation and social disarticulation. They attribute the impoverishment to absence of guidelines for invited spaces for the poor community to engage with the government during the design, planning and implementation of projects under the program.

Table 10: Budget for marginalised population from total city budget (from 2012 to 2015)

\begin{tabular}{|l|l|l|l|l|l|l|}
\hline & $\begin{array}{l}\text { Annexure B } \\
\text { Budget } \\
\text { 2012-2013 } \\
\text { (INR } \\
\text { Millions) }\end{array}$ & $\begin{array}{l}\text { Annexur } \\
\text { e B } \\
\text { budget } \\
\text { as \% of } \\
\text { Municipal } \\
\text { Budget }\end{array}$ & $\begin{array}{l}\text { Annexure } \\
\text { B Budget } \\
\mathbf{2 0 1 3 - 2 0 1 4} \\
\text { (INR } \\
\text { Millions) }\end{array}$ & $\begin{array}{l}\text { Annexure } \\
\text { B budget } \\
\text { as \% of } \\
\text { Municipal } \\
\text { Budget }\end{array}$ & $\begin{array}{l}\text { Annexure } \\
\text { B Budget } \\
\text { 2014-2015 } \\
\text { (INR } \\
\text { Millions) }\end{array}$ & $\begin{array}{l}\text { Annexure } \\
\text { B budget } \\
\text { as \% of } \\
\text { Municipal } \\
\text { Budget }\end{array}$ \\
\hline $\begin{array}{l}\text { Annexure B } \\
\text { Budget (for } \\
\text { marginalised } \\
\text { population) }\end{array}$ & 2127 & 1550 & & 3606 & \\
\hline Total Budget & 45110 & $4.72 \%$ & 49510 & $3.13 \%$ & 53010 & $6.80 \%$ \\
\hline
\end{tabular}

Source: Ahmedabad Municipal Corporation Budgets

In response to denial of invited spaces for engagement and the consequent implications on their well-being, slum communities have occasionally mobilised and claimed spaces for engagement (Mahadevia, 2014) as also proposed by Gaventa (2006). However these have been one off "claimed spaces" which closed once the common interests of mobilisation were achieved. One example is the space for engagement claimed by a slum community based platform named Sabarmati Nagarik Adhikar Manch (SNAM) (meaning Sabarmati Riverfront Residents' Rights Forum). SNAM was created in 2003-2004 by mobilisation of about 14500 slum households living along the Sabarmati River which were going to be displaced by the river beautification project locally called Sabarmati Riverfront Development (SRFD). SNAM's objective was to negotiate with AMC and political parties the recognition of right to shelter of slum dwellers in general and the right to resettlement in alternative sites in proximity to the current residences of the households displaced by SRFD in specific. Through negotiating efforts they met with limited success as the state and local government authorities responded with vague assurances of 
resettling all the slum households to be displaced under SRFD but did not follow up with concrete actions or share information on the project's resettlement policy. When it became increasingly clear that there was no mention of resettlement in the project, SNAM stopped the negotiating efforts and instead took judicial recourse by filing a Public Interest Litigation (PIL) in the High Court of Gujarat in 2005 with help from NGOs and civil rights activists. Tracing the PIL from 2005 till its disposal in 2011 Desai (2014) shows how through judicial intervention SNAM could claim and achieve resettlement dwelling units for 10000 displaced households albeit in a non-transparent and adhoc manner from AMC. But she also cautions that SNAM could not become a platform for claiming a rights-based and transparent resettlement and rehabilitation process for slum dwellers. Mahadevia (2014) cautions that SNAM and PIL were one-off mechanisms of claiming spaces for engagement with the local state. Hence when judicial process ended, negotiations also ended and the space closed. In absence of a permanent invited space a recourse to judiciary to claim space for negotiating their rights has become an expensive process for the poor in Ahmedabad (Mahadevia, 2014). But the neoliberal GoG and AMC which deem democratic deliberation through invited spaces inefficient do not institutionalise permanent "spaces" despite frequent claim making by the unpropertied poor (ibid).

\subsection{Conclusion}

The main inquiry of the paper was how different spaces for participation in local governance have been created or claimed, on what terms of engagement and whose interests they serve in Ahmedabad.

The research shows a progressive weakening of mandate for participatory governance from the top to bottom tiers of government. First, there is a reduction in mandates of WCs and ASs by the state government policy out of the envisaged mandates given by the national government under $74^{\text {th }}$ CAA and JNNURM's CPL reform. The reduction was in terms of reduced proximity, differentiated citizen participation that excluded poor community, limited and unclear functions and no financial autonomy. This evidence reiterates the view (Sridharan, 2008, Baud and Nainan, 2008, Sivaramakrishnan, 2000, deWit et al., 2008) that State and local governments are reluctant to share power with invited spaces. Our research also reiterates the view that policy for invited spaces (Kundu, 2011, Baud and Nainan, 2008, Swyngedouw, 2005) is designed to allow capture by local elites.

While the state government's mandate for participatory governance is weak the practice by the local government is even weaker, causing more adverse implications on the quality of life of the poor than on the middle class. At local level, ASs are not formed in any ward and WCs are formed but function as closed spaces. Thus all citizens are denied the right to engage in the three 
critical areas of influence i.e formulation, passing and implementation of public policies as advocated by Parry et al (1992) or to be "makers and shapers" as advocated by (Nainan and Baud, 2008, Cornwall and Gaventa, 2001, Devas, 2004).

In absence of invited spaces, the two predominant social groups i.e the propertied and the unpropertied take a recourse to other platforms to negotiate their socio-economic needs as "user and choosers" as shown by Cornwall and Gaventa (2001) with varying responsiveness. As shown by other researchers (Kundu, 2011, Baud and Nainan, 2008, Teeffelen and Baud, 2011, deWit et al., 2008) the middle class successfully use the executive wing at ward and zone levels and the e-governance and m-governance platforms to negotiate their needs whereas the poor community relies on the elected representatives, but meets with limited success. In contradiction to experience of other cities in India (deWit et al., 2008), in Ahmedabad even the elected representatives from both the ruling and the opposition parties have shown more bias and responsiveness towards the middle class than to the poor, despite the latter forming $26 \%$ of their vote bank at the city level as the former are emerging as more favoured and influential social group. Thus, while in other cities the poor have strategically and successfully negotiated their needs through clientelism with the elected representatives (Teeffelen and Baud, 2011), in Ahmedabad this platform is also captured by the elite middle class, which has emerged as a more influential and favoured electorate in neoliberal Ahmedabad, as has been suggested by scholars (Swyngedouw, 2005, Crook and Sverrisson, 2003a)

Exclusion of slum community from invited spaces in routine local governance processes and in specific programs which influence them, has resulted in their further economic and social impoverishment in Ahmedabad as shown by Patel et al (2015). In response, slum communities frequently claim space for engagement through judicial recourse as proposed by Gaventa (2006). SNAM, represents one such "claimed space" through which slum residents claimed right to shelter in general and to compensatory shelter on sites close to residence of evictees and to all households as per their enumeration survey and partially succeeded. However such claimed spaces are one-off mechanisms which close on end of judicial process rather than culminate into permanent invited spaces for engagement in local governance as proposed by Gaventa (2006).

To conclude, we find all three types of participatory spaces proposed by Gaventa (2006) but fail to find empirical evidence of the dynamic interrelationship between them that he suggests. The inclusiveness and empowerment in participatory governance rhetoric is not realized in AMC's practice because of neoliberal ideological shifts that democratic deliberation is 
inefficient and the middle class is a more desirable electorate. The latter has led to inequalities between the two social groups in terms of difference in success to negotiate socio-economic rights. 


\section{Chapter 4}

Claiming shelter rights for the unpropertied citizens in a neoliberal city: is the judiciary aligned with the state's ideology ${ }^{2}$

2 This chapter is based on Patel S, Georgiadou Y, Sliuzas R, 2016, "Claiming shelter rights for the unpropertied in a neoliberal city: judicial stance aligned with state's ideology?"(submitted to Human Rights Quarterly: under review) 


\begin{abstract}
In the absence of an institutionalised invited space for participation and negotiation with the local government, the unpropertied poor often take judicial recourse to claim socio-economic rights through petitions. The research explores the constitutionality upon which two such petitions were filed, the response of the State and local governments to the petitions through affidavits, interpretation of the constitutionality by the judiciary in its final order, the State and local governments' response to the judicial order and the outcome of the judicial process for the rights of the unpropertied. The petitions in Gujarat High Court were initiated by two different slum communities, one seeking right to basic services and the other seeking the right to shelter and revision of the cut-off date (from 1976 to 1995) for compensatory shelter in case of unavoidable eviction. Our research reveals that the State High Court perpetuates the State and local government's neoliberal growth agenda and stance on rights of the unpropertied but not blatantly. The Court assumes a duplicitous stance of "stealthy sympathy" with the local government and of "not blatant apathy" towards the poor. It allows the poor to win small battles by halting evictions or ordering "conditional" access to basic services but paves the way for the local government to win the war by actively disregarding the rights based discourse of the poor which could potentially hinder neoliberal development. As a consequence, basic services are transformed into highpriced commodities, the right to shelter is denied and compensatory shelter remains limited to the cut-off date of 1976 . The terms of citizenship are discursively reconstituted on a property basis and the claimed spaces do not become open participatory spaces upon closure of the claim making process given the neoliberal bias of the local and State government and the judiciary.
\end{abstract}

Keywords: right to shelter, right to basic services, judiciary, public interest litigation (PIL), neoliberalism, citizenship 


\subsection{Introduction}

In chapter 1, I discussed the processes of neoliberalisation in India in general and in the state of Gujarat and the city of Ahmedabad in particular (section 1.3) and the changing stance of Ahmedabad Municipal Corporation on the right to shelter and basic services of unpropertied citizens. I discussed the changing stance of the Supreme Court of India and high courts of a few states on these rights with rise of neoliberalisation in India. That discussion with additional deepening in chapter 2 provide the theoretical basis for the empirical research related to judicial rulings and what they imply about the judiciary's relationship with governmental ideology and the rights of the unpropertied citizens.

In this chapter we inquire further whether Rajagopal's (2007) postulation that the judiciary's approach to human rights is in congruence with government's ideology of development is valid in the case of Gujarat High Court's rulings on the socio-economic rights of the unpropertied poor in Ahmedabad, especially given that this city is known to pursue a neoliberal transformation more aggressively than most cities of India (Chatterjee, 2014, Mahadevia, 2002). We analyse two petitions by two different slum communities in the Gujarat High Court, one seeking the right to basic services and the other seeking the right to shelter and revision of the cut-off date (from 1976 to 1995) for compensatory shelter in case of unavoidable eviction. As cut-off date revision falls in the purview of the local and State governments both were made respondents in this petition. We analyse the constitutionality upon which the petitions were filed, the responses of the State and local governments through affidavits, interpretation of the constitutionality by the judiciary in its final order and, the State and local governments' responses to judicial order and what this meant for the unpropertied citizens and their rights.

\subsection{Methods}

Qualitative methods were used to collect and analyse primary and secondary data for the two cases. Primary data included key respondents' interviews that we analysed through discourse analysis to learn how specific actors construct an argument and how this argument fits into the wider social practices as suggested by Chilton \& Schäffner (2002). To understand the evolution of the case on right to shelter and cut-off date from the petition till the final judicial order and the governments' response to the order, documents were collected from five actors: AMC, GoG's Urban Development and Urban Housing Department (UD\&UHD) who were made respondents, a civil right activist group Jan Sangharsh Manch (JSM), meaning forum for citizens struggle, which was the petitioner on behalf of slum community, and the High Court of Gujarat and the Supreme Court of India where the petition and appeal on the petition were filed. Details of documents collected from these actors are shown in Table 11.

Table 11: Documents collected for petition on 1976 cut-off date 


\begin{tabular}{|c|c|c|}
\hline Source & Document date & Document \\
\hline AMC & $7 / 2 / 2005$ & $\begin{array}{l}\text { Standing Committee (SC) Resolution numbered } \\
\mathbf{1 2 7 4} \text { deciding to shift cut-off date from } 1976 \text { to } 1995\end{array}$ \\
\hline AMC & $30 / 6 / 2005$ & $\begin{array}{l}\text { SC Resolution } 426 \text { stating Municipal Commissioner } \\
\text { should start survey of slums in existence prior to } \\
1995\end{array}$ \\
\hline AMC & $22 / 7 / 2005$ & $\begin{array}{l}\text { SC Resolution } 346 \text { stating dissatisfaction with } \\
\text { Municipal Commissioner on no action taken, survey to } \\
\text { be completed in } 30 \text { days }\end{array}$ \\
\hline AMC & $5 / 1 / 2006$ & $\begin{array}{l}\text { Municipal Commissioner's request letter to GoG to } \\
\text { suspend resolutions } 1274,426,346\end{array}$ \\
\hline GoG & $23 / 6 / 2006$ & $\begin{array}{l}\text { GoG's letter deciding to suspend the three resolutions } \\
\text { to revise cut-off date back to } 1976 \text { from } 1995\end{array}$ \\
\hline Petitioner JSM & $29 / 8 / 2007$ & $\begin{array}{l}\text { PIL in High Court against GoG and AMC (respondents) } \\
\text { numbered Special Civil Application (SCA) } \mathbf{2 3 6 3 7} \\
\text { of } \mathbf{2 0 0 7} \text { to quash GoG order dated 23/6/2006, to } \\
\text { stay evictions in the pendency. }\end{array}$ \\
\hline $\begin{array}{l}\text { Gujarat High } \\
\text { Court }\end{array}$ & $13 / 9 / 2007$ & $\begin{array}{l}\text { Interim order notifying respondents to file response } \\
\text { to PIL by affidavits by } 9 / 10 / 2007 \text { and staying } \\
\text { evictions till final order }\end{array}$ \\
\hline UD\&UHD, GoG & $9 / 10 / 2007$ & $\begin{array}{l}\text { Affidavit to } \mathrm{HC} \text { reasoning and upholding suspension of } \\
\text { resolutions }\end{array}$ \\
\hline AMC & $8 / 7 / 2008$ & $\begin{array}{l}\text { Affidavit to } \mathrm{HC} \text { supporting suspension of resolutions } \\
\text { by GoG }\end{array}$ \\
\hline $\begin{array}{l}\text { Gujarat High } \\
\text { Court }\end{array}$ & $12 / 11 / 2008$ & $\begin{array}{l}\text { Final order vacating stay on eviction, directing GoG } \\
\text { to take final decision in four months, disposing SCA } \\
\mathbf{2 3 6 3 7}\end{array}$ \\
\hline JSM & $29 / 1 / 2009$ & $\begin{array}{l}\text { Appeal to Supreme Court numbered Special Leave } \\
\text { Petition (SLP) } \mathbf{2 5 0 4} \text { of } \mathbf{2 0 0 9} \text {. Petitioning that HC } \\
\text { has erred by remanding matter back to GoG }\end{array}$ \\
\hline $\begin{array}{l}\text { Supreme } \\
\text { Court }\end{array}$ & $23 / 2 / 2009$ & $\begin{array}{l}\text { Final order staying evictions till "final decision" taken } \\
\text { by GoG. SLP } \mathbf{2 5 0 4} \text { disposed }\end{array}$ \\
\hline AMC & $18 / 6 / 2009$ & $\begin{array}{l}\text { SC Resolution numbered } \mathbf{2 6 5} \text { cancelling resolutions } \\
\text { of } 2005 \text { on cut-off date of } 1995\end{array}$ \\
\hline UD\&UHD, GoG & $9 / 12 / 2009$ & $\begin{array}{l}\text { GoG's minutes of the meeting to "carefully hear" both } \\
\text { AMC and JSM }\end{array}$ \\
\hline UD\&UHD, GoG & $4 / 2 / 2010$ & $\begin{array}{l}\text { GoG order taking "final decision" to suspend cut-off } \\
\text { date of } 1995\end{array}$ \\
\hline JSM & $20 / 4 / 2010$ & $\begin{array}{l}\text { Filed SCA } 12331 \text { of } 2010 \text { in High Court against GoG } \\
\text { orders of } 23 / 6 / 2006 \text { and } 4 / 2 / 2010 \text { on grounds of } \\
\text { being contrary to law, reasons, justice and equity }\end{array}$ \\
\hline $\begin{array}{l}\text { Gujarat High } \\
\text { Court }\end{array}$ & $25 / 10 / 2010$ & $\begin{array}{l}\text { Final order Decides not to interfere with GoG } \\
\text { decision on suspension of } 1995 \text { cut-off date and } \\
\text { disposes SCA 12331 }\end{array}$ \\
\hline
\end{tabular}

Media reports on the case were collected. To understand the slum community's grievances and motivation for claim-making and position of actors in AMC and GoG on the claims, we interviewed activists in JSM, community leaders, senior officials in AMC and councillors from both the opposition and the ruling political party in AMC. We did textual analysis of these documents with the objective to understand each actor's position on (mis)recognition of rights of the poor by AMC. We identified discursive devices, turns of phrase producing a specific effect, used by the actor to advance their position. While the position of the state actors and petitioners on (mis)recognition of rights by AMC was known a priori, the objective was to reveal the higher judiciary's position on the same and the discursive devices used by actors to advance their position.

Table 12: A priori understanding of positions of various actors on 
(mis)recognition of rights of urban poor by AMC

\begin{tabular}{|l|l|l|}
\hline \multirow{2}{*}{$\begin{array}{l}\text { Actor's } \\
\text { Position }\end{array}$} & \multicolumn{2}{|l|}{$\begin{array}{l}\text { A priori understanding of actors' position on } \\
\text { (mis)recognition of right to shelter by AMC }\end{array}$} \\
\cline { 2 - 3 } & right to shelter & $\begin{array}{l}\text { (mis)recognition of right to } \\
\text { shelter by AMC }\end{array}$ \\
\hline Petitioner & Pro-shelter right & $\begin{array}{l}\text { AMC anti poor and their rights, pro- } \\
\text { private property owners and } \\
\text { developers }\end{array}$ \\
\hline AMC & Anti-shelter right & Anti-shelter right in "public" interest \\
\hline GoG & Anti-shelter right & $\begin{array}{l}\text { Blatant sympathy and allegiance with } \\
\text { AMC }\end{array}$ \\
\hline $\begin{array}{l}\text { Gujarat High } \\
\text { Court } \\
\text { /Supreme } \\
\text { Court of India }\end{array}$ & $\begin{array}{l}\text { Not blatantly anti-poor and } \\
\text { their rights? }\end{array}$ & Subtle sympathy with AMC and GoG?? \\
\hline
\end{tabular}

For the petition on the right to basic services, we collected documents from three actors: AMC which was the respondent, Gujarat High Court and, community association of Ganeshnagar slum called Ganeshnagar Nagrik Ekta Samiti (GNES), the Committee of Unity of Ganeshnagar Residents, which had filed the petition against AMC. Details of the documents collected are shown in Table 13.

Table 13: Documents collected from concerned actors in case of petition on

\begin{tabular}{|c|c|c|}
\hline \multicolumn{3}{|c|}{ right to basic se } \\
\hline Source & Document date & Document \\
\hline Petitioner GNES & $17 / 4 / 2001$ & $\begin{array}{l}\text { Petition in High Court against AMC numbered SCA } \mathbf{2 7 1 6} \text { of } \\
\text { 2001. That AMC should provide unhindered water, } \\
\text { sewerage and electricity connection }\end{array}$ \\
\hline $\begin{array}{l}\text { Gujarat } \\
\text { Court }\end{array}$ & $1 / 5 / 2001$ & $\begin{array}{l}\text { Interim order directing AMC to provide unhindered water, } \\
\text { sewerage and electricity connection to slum dwellings }\end{array}$ \\
\hline AMC & $8 / 8 / 2001$ & $\begin{array}{l}\text { SC Resolution numbered } 543 \text { passed announcing } 1500 \\
\text { NOC scheme to provide legal water and sewerage } \\
\text { connection to slum dwellings }\end{array}$ \\
\hline AMC & $28 / 9 / 2001$ & $\begin{array}{l}\text { General Board resolution numbered } 449 \text { approving the } \\
\text { above resolution }\end{array}$ \\
\hline AMC & 19/10/2001 & $\begin{array}{l}\text { Affidavit to HC briefing about action taken i.e formulation } \\
\text { of } 1500 \text { NOC scheme. }\end{array}$ \\
\hline $\begin{array}{l}\text { Gujarat High } \\
\text { Court }\end{array}$ & 19/10/2001 & $\begin{array}{l}\text { Interim order stating higher bench required for decision } \\
\text { on fees for NOC. AMC to continue } 1500 \text { NOC scheme in the } \\
\text { meantime. }\end{array}$ \\
\hline $\begin{array}{l}\text { Gujarat High } \\
\text { Court }\end{array}$ & $24 / 3 / 2009$ & $\begin{array}{l}\text { Final order approving } 1500 \text { NOC scheme provisions and } \\
\text { disposing SCA } \mathbf{2 7 1 6}\end{array}$ \\
\hline
\end{tabular}

\subsection{The petition on right to shelter and revision of the cutt- off date for compensatory shelter}

AMC recognises the right to compensatory shelter upon eviction only for those slums which were notified in 1976 which constitute less than half of the city's 
current slum population. Inception of the neoliberal transformation of the city in the mid-1990s through beautification and infrastructure projects had led to eviction of slum dwellers from city core area but compensatory shelter was offered to only a meagre few who could prove residence in slum prior to 1976 and 2002 in case of SRFD.

To appease the poor electorate ahead of upcoming election in October 2005, the elected wing of AMC constituting the Standing Committee (of selected representatives) (SC) and the General Board (of all elected representatives) passed a resolution in early 2005 deciding "not to remove the hutments in existence up to December 1995 without providing alternative accommodation and to carry out a survey of the hutments (that came into existence) up to December 2001."14 The cut-off date was thus advanced from 1976 to 1995 and the right to compensatory shelter was recognised for more slum dwellers. Though the resolution was moved by councillors of the ruling party in a bid to retain the civic body for a second term, it was also supported by BJP, the opposition party in the face of the upcoming elections. However the Municipal Commissioner who is the executive head of AMC did not take any action to implement a democratically passed resolution, indicating an inherent anti-poor bias in the executive in Ahmedabad (Chatterjee, 2014, Mahadevia, 2002). The Commissioner's resistance continued despite two subsequent resolutions by AMC's General Board which censured delay in work and set a deadline of 30 days for completion of the survey. ${ }^{15}$ On the contrary, on conclusion of the election, the Commissioner moved to suspend all three AMC resolutions (1274, 426 and 346) around an advanced cut-off date of 1995. This was done with the support of councillors from the victorious political party BJP, which is known for business friendly and pro-middleclass politics (Desai, 2006, Chatterjee, 2014), by appealing to GoG to exercise its powers to suspend municipal resolutions.

AMC's appeal to GoG stated "It is not necessary to provide alternative accommodation to the occupiers who are sought to be removed under the Town Planning Act or other laws. However, adopting a humanitarian approach, the earlier Municipal Commissioner... decided a policy of providing alternative accommodation to the slum dwellers who were holding slum survey receipt of the hutments prior to 1976." AMC cited "public interest" for restoring the 1976 cut-off date by stating that shifting the cut-off date to December 1995 would mean recognising right to compensatory shelter of more slum dwellers and this would "obstruct the development of the city", "hamper handing over possession of the developed land to private owners", "cause liability of large land parcel and heavy financial burden on AMC", "encourage the encroachers", "increase the encroachments" and "(removal of encroachments would) give rise to legal complications. ${ }^{16}$ Using these discursive devices AMC began framing slum dwellers as against "public" interest, thereby "othering" them 
from the "public" whose interest had to be protected. It began to frame provision of compensatory shelter to slum dwellers as a humanitarian approach of a benevolent state rather than a matter of right of the poor. The proproperty owner stance of AMC in the petition was reiterated by a local daily which stated that "AMC wrote to the state government to suspend 1995 as the cut-off date as it wanted to preserve land for private development by property owners" (Nayudu, 2009).

Table 14: Summary of Actors' stance on the petition on shelter right and cutoff date

\begin{tabular}{|l}
\hline Timeline and Action by Actor \\
\hline $\mathbf{7 / 2 / 2 0 0 5}$ AMC Resolution to shift cutoff date from \\
1976 to 1995
\end{tabular}

30/6/2005 AMC SC Res : Municipal Commissioner should start survey of slums in existence prior to 1995 22/7/2005 AMC SC Res: Dissatisfaction with Municipal Commissioner on no action taken, survey to be completed in 30 days

1/5/2006 AMC Municipal Commissioner requests Government of Gujarat (GoG) to suspend resolutions $1274,426,346$

23/6/2006 GoG suspends all resolutions. Cut-off date back to 1976

Evictions of slums continue, compensatory shelter to only 1976 cut-off families

29/8/2007 JSM files PIL in High Court against GoG and AMC (respondents). Petition to quash GoG order on cut-off date reversal and to stay evictions in pendancy.

Petition on grounds of right to shelter under right to life

in article 21 and right to equality of all before law under article 14. Special Civil Application (SCA) No 23637 of 2007

$\mathbf{1 3 / 9 / 2 0 0 7 ~ H C ~ i n t e r i m ~ o r d e r : ~ N o t i c e ~ t o ~ r e s p o n d ~ b y ~}$ affidavits by $9 / 10 / 2007$, stay on evictions till final order

9/10/2007 GoG affidavit to $\mathrm{HC}$ explaining and upholding suspension of resolution on 1995 cut-off

\section{Actor's stance}

AMC's (elected wing) sympathy towards shelter right and cut-off date prior to elections

7/8/2008 $A M C$ affidavit to $\mathrm{HC}$ explaining and upholding suspension of resolutions in favour of progress of the city

11/12/2008 HC final order: Vacates stay on eviction, directs GoG to take final decision in four months. SCA 23637 disposed

GoG does not take "final decision" within four months

AMC-GoG allegiance in anti-poor, antishelter right stance date

um community mobilisation to claim

Duplicitous Judicial stance: narrow sympathy to poor limited to staying evictions, apathy by actively disregarding right based plea

udiciary's stealthy sympathy to state : contempt of Court by AMC and GoG but no rebuke

AMC SC passes resolution to give new housing built under BSUP only to slum dwellers existing prior to 1976 


\begin{tabular}{|c|c|}
\hline Timeline and Action by Actor & Actor's stance \\
\hline $\begin{array}{l}\text { 29/1/2009 Aggrieved by the HC decision, JSM } \\
\text { petitions Supreme Court that HC has erred by } \\
\text { remanding matter back to GoG, that interim stay on } \\
\text { evictions be given till final decision by GoG. Special } \\
\text { Leave Petition (SLP) } \mathbf{2 5 0 4} \text { of } \mathbf{2 0 0 9}\end{array}$ & $\begin{array}{l}\text { Community's appeal to Supreme Court } \\
\text { on being aggrieved by High Court }\end{array}$ \\
\hline $\begin{array}{l}\mathbf{2 3 / 2 / 2 0 0 9} \text { SC final order: Stay on evictions till "final } \\
\text { decision" taken by GoG. GoG to give reasonable } \\
\text { opportunity to appeal to petitioners before final } \\
\text { decision. SLP } \mathbf{2 5 0 4} \text { disposed }\end{array}$ & $\begin{array}{l}\text { Supreme Court actively disengaged } \\
\text { from rights based discourse, stealthy } \\
\text { sympathy to AMC and GoG, remands } \\
\text { GoG to take "final decision" }\end{array}$ \\
\hline $\begin{array}{l}\mathbf{1 8 / 6 / 2 0 0 9} \text { AMC SC Res: cancel resolutions of } 2005 \text { on } \\
\text { cut-off date of } 1995 \text { thus violating HC order. } \\
\text { Resolution No } \mathbf{2 6 5}\end{array}$ & $\begin{array}{l}\text { AMC's democratic decision to cancel } \\
1995 \text { cut-off }\end{array}$ \\
\hline $\begin{array}{l}\mathbf{1 2 / 9 / 2 0 0 9} \text { GoG gives "careful hearing" to both AMC } \\
\text { and JSM for and against the suspension of resolution on } \\
1995 \text { cut-off. } \\
\mathbf{2 / 4 / 2 0 1 0 ~ G o G ~ t a k e s ~ " f i n a l ~ d e c i s i o n " ~ t o ~ s u s p e n d ~ c u t - ~} \\
\text { off date of } 1995 \text { and revert to } 1976 \text { for future programs }\end{array}$ & $\begin{array}{l}\text { GoG "final decision" to uphold cut-off } \\
\text { date reversal from } 1995 \text { to } 1976 .\end{array}$ \\
\hline $\begin{array}{l}\mathbf{2 0 / 4 / 2 0 1 0} \text { JSM files PIL in High Court against GoG } \\
\text { orders of } 23 / 6 / 2006 \text { and } 4 / 2 / 2010 \text { on grounds of being } \\
\text { contrary to law, reasons, justice and equity. SCA No: } \\
\mathbf{1 2 3 3 1} \text { of } \mathbf{2 0 1 0}\end{array}$ & $\begin{array}{l}\text { Community's one more appeal to } \\
\text { judiciary on grounds of justice, equity } \\
\text { and illegality of GoG decision }\end{array}$ \\
\hline $\begin{array}{l}\text { 25/10/2010 HC final order: Decides not to interfere } \\
\text { with GoG decision on suspension of } 1995 \text { cut-off date. } \\
\text { SCA } 12331 \text { disposed }\end{array}$ & $\begin{array}{l}\text { Continued stealthy sympathy of } \\
\text { judiciary to AMC and GoG }\end{array}$ \\
\hline
\end{tabular}

The GoG, in a blatant show of sympathy and allegiance to AMC, accepted these arguments and supported cancellation of the 1995 cut-off date by passing an order suspending the said resolutions. ${ }^{17}$ Emboldened by the GoG order, AMC continued evictions of slums under ongoing neoliberal projects, with compensatory shelter given only to a few as per the 1976 cut-off. Being aggrieved of their right to compensatory shelter, some slum community members along with a civil right organization Jan Sangharsh Manch (JSM) filed a petition against GoG and AMC in the High Court appealing to squash the GoG order of suspension of AMC resolutions and to stay evictions of slums in pendency, till final order of the Court.

The petition requested the Court to enforce slum dwellers' fundamental right to equality of all before law under article 14 and fundamental right to shelter under article 21 (right to life and personal liberty). It framed the concept of a restrictive cut-off date to give compensatory shelter to only a select few slum dwellers as discriminatory and hence in violation of Article 14. It argued that right to shelter is ingrained in the right to life under Article 21 as upheld by the Supreme Court of India in the landmark case of AMC vs. Nawab Khan Gulab Khan (1996), discussed earlier in section 1.3. Thus while stating that the right to shelter is a fundamental right and should be extended to all slum dwellers irrespective of the date of residence, the petition articulated a rights-based discourse for the poor. 
The petition further appealed that GoG only has powers to suspend AMC resolutions if resolutions were in contravention of the provisions of the Gujarat Municipal Corporation Act of 1949. Since provision of shelter to the poor is an obligatory function of a Municipal Corporation under this Act and the AMC resolutions for revision of the cut-off date were not contravening these stipulations the petition appealed that "GoG's impugned order is without any sanction of law and therefore void." 18

The petition censured AMC and GoG's anti-poor and pro-property owners bias by stating that ".it is strange and very much shocking that a beneficial piece of legislation (of 1995 cut-off date) and consequential resolutions passed there under are now being dubbed as encouraging land grabbing. The fact is however, exactly contrary as the impugned order itself would show that AMC itself is giving away the land to private builders and its only intention is to enrich the private builders for extraneous considerations at the cost of the poor hutment dwellers. In that view of the matter, the impugned order is required to be quashed and set aside."19 The petition thus articulated a rights-based discourse for the poor by stating that the GoG's order was illegal, arbitrary, malafide and unconstitutional.

Initially the High Court showed sympathy to the poor by granting a stay order on implementation of the GoG order till final judicial verdict, meaning that cutoff date of 1995 would be operational in the meantime. It notified AMC and GoG to file their affidavits in response to the petition. In their affidavits both GoG and AMC continued framing the poor as encroachers and against the "public" interest.

GoG resolutely rejected the rights of the poor claimed in the petition by stating that "none of the fundamental or legal right of the petitioner has been violated because of any action or inaction on part of (GoG)." The GoG questioned the very citizenship of the poor by stating that ".any encroacher does not have a fundamental right to claim alternative accommodation from the authority. "20 It reiterated its sympathy and allegiance with AMC by stating "The resolution passed by $A M C$, if allowed to operate, would encourage the encroachers. It would promote many persons to encroach upon the public land so that they can get alternative accommodation. If the same land is required by the authority for any legal purpose for implementation of various schemes, it will tremendously burden the AMC." 21 Thus it continued discursive framing of slum dwellers as "encroachers", "illegal" and against "public" interest, thereby othering the slum dwellers from the "public".

In much the same way AMC continued the discursive framing of slum dwellers by stating "In order to keep pace with the overall development of the city which has attained the status of Mega city and in order to undertake necessary and 
important projects like BRTS, riverfront and lake front development and roads and flyovers, AMC has to undertake exercise of evicting persons, who have illegally occupied such lands" and "an encroacher does not have any fundamental right to claim alternative accommodation from an authority." 22 Interestingly, AMC filed its affidavit in reply to the Court's notice more than ten months after the stipulated deadline without any recorded censure from the Court.

Ultimately, the High Court's response to AMC and GoG's affidavits was of stealthy sympathy as it ordered that GoG's decision was not final and directed it to take the "final decision" within four months. Its tone of stealthy sympathy is clear when it states "Taking into consideration the difficulties expressed by the Municipal Commissioner in implementing the resolutions, the Government has suspended the Resolutions" and ".the grievances raised by the petitioners were taken note of by the Government while suspending the Resolutions" and ".since the matters are seized by the Government, it would be appropriate for the Government to take a final decision on these matters." 23 The Court thus disposed the petition and stay on evictions, and referred the matter back to GoG for final decision. As neither GoG nor AMC had claimed in their affidavits that GoG's order was interim and not final, the Court's deliberate misreading of the affidavits and remanding GoG to take final decision was an evidence of its "stealthy sympathy" with the state. Furthermore the Court actively disengaged from right's based discourse in petition that sought the right to shelter as a fundamental right.

In the meantime when GoG had yet to take the final decision, AMC continued evictions and provided compensatory shelter as per the 1976 cut-off, thereby limiting its "liability" and responsibility. Aggrieved by the High Court, the petitioners carried their grievance to Supreme Court of India appealing that the ".High Court had misread and misconstrued the (JSM) petition and the affidavits of AMC and GoG and it had erred by remanding the matter back to GoG and by vacating the interim stay on evictions of slums." 24 The Supreme Court disposed the appeal by granting interim stay on evictions of slums till the GoG took the final decision after giving reasonable opportunity of being heard to the petitioner. Though the Supreme Court granted interim stay, it did not respond to the petition's plea against the High Court order and in fact endorsed the latter's order by once more ordering the GoG to take the final decision. Thus the judiciary's stealthy sympathy to the government at the cost of the poor continued.

Under the order of Supreme Court, AMC was compelled to stay evictions of slums. But needing to hasten implementation of the neoliberal projects through appropriation of land from slums, AMC passed a resolution to cancel its own resolutions of 2005 on revision of cut-off date from 1976 to $1995^{25}$. With this 
resolution AMC could continue evictions without it being considered contempt of the Supreme Court's order. It also set an enabling background for GoG's impending "final decision" by creating a rhetoric that a "democratic decision on 1995 cut-off reversal has already been taken by the elected wing of AMC." 26 As said by a slum community leader, ".this resolution reflected the new reality; that even the elected wing which had earlier passed a populist, pro-poor resolution had now become exclusionary towards the poor and favoured the interests of the middle class segment that aspires a Singapore (world-class city) in Ahmedabad." 27

Against this background and after giving "careful hearing" to the petitioner JSM, GoG took the "final decision" to suspend AMC resolutions of 2005 under which the cut-off date was advanced from 1976 to 1995 and the right to compensatory shelter was recognised for a larger number of slum dwellers. Thus, after a struggle of three years the slum community's claim for right to shelter as a fundamental right in general and for compensatory shelter on eviction for a larger number in particular was rejected both by the judiciary and the local and State governments under their neoliberal bias.

Through the entire discourse, AMC and GoG in mutual allegiance framed slum dwellers as "encroachers" "illegal", "obstruction to progress and development of the city", "financial liability to the city" and questioned the very basis of their citizenship by proclaiming that "an encroacher does not have any fundamental right". This view was reiterated by senior official in AMC as well as councillors from both the ruling and opposition parties. ${ }^{28}$ By framing slum dwellers as against the "public" interest they are othered from the "public" i.e. the propertied citizenry. Thus a new notion of citizenship is advanced, one which is based on property ownership, making the un-propertied poor as second class citizens and secondary to the propertied ones. The judiciary not only allowed AMC and GoG to continue this discourse and disavow shelter right of the unpropertied without censure, as it had hitherto done in such petitions till late 1980 s, it in fact showed stealthy sympathy with both. 
Table 15: Position and discursive devices of actors on (mis)recognition of shelter right by AMC

\begin{tabular}{|c|c|c|}
\hline \multirow[t]{2}{*}{ Actor } & \multicolumn{2}{|c|}{$\begin{array}{l}\text { Actors' position and discursive devices on claim to right to } \\
\text { shelter and (mis)recognition of the right by AMC }\end{array}$} \\
\hline & Shelter right & $\begin{array}{l}\text { (mis)recognition of shelter right } \\
\text { by AMC }\end{array}$ \\
\hline $\begin{array}{l}\text { Petitioners' } \\
\text { position }\end{array}$ & Pro-shelter right & $\begin{array}{l}\text { AMC anti poor and shelter right, pro- } \\
\text { property owners }\end{array}$ \\
\hline $\begin{array}{l}\text { Petitioners. } \\
\text { discursive } \\
\text { devices }\end{array}$ & $\begin{array}{l}\text { right to shelter a fundamental } \\
\text { right under right to life, } \\
\text { equality of all before law a } \\
\text { fundamental right }\end{array}$ & $\begin{array}{l}\text { illegal, arbitrary, malafide, } \\
\text { unconstitutional }\end{array}$ \\
\hline $\begin{array}{l}\text { AMC's } \\
\text { Position }\end{array}$ & Anti-shelter right & Anti-shelter right in "public" interest \\
\hline $\begin{array}{l}\text { AMC's } \\
\text { discursive } \\
\text { devices }\end{array}$ & $\begin{array}{l}\text { Slum dwellers are encroachers, } \\
\text { encroacher has no fundamental } \\
\text { rights, }\end{array}$ & $\begin{array}{l}\text { against "public interest" "obstructing } \\
\text { development of city", "causing } \\
\text { liability of large land parcel and } \\
\text { heavy financial burden on AMC", } \\
\text { "hampering handing over developed } \\
\text { land to property owners" result in } \\
\text { "encouraging encroachers", } \\
\text { "increasing encroachments" }\end{array}$ \\
\hline $\begin{array}{l}\text { GoG's } \\
\text { position }\end{array}$ & Anti-shelter right & $\begin{array}{l}\text { Blatant sympathy and allegiance } \\
\text { with AMC }\end{array}$ \\
\hline $\begin{array}{l}\text { GoG's } \\
\text { discursive } \\
\text { devices }\end{array}$ & $\begin{array}{l}\text { Slum dwellers as encroachers, } \\
\text { against "public" interest, illegal, } \\
\text { obstruction to progress and } \\
\text { development, encroacher has } \\
\text { no fundamental rights }\end{array}$ & $\begin{array}{l}\text { AMC as humanitarian, heavily } \\
\text { burdened with duty }\end{array}$ \\
\hline $\begin{array}{l}\text { Court's } \\
\text { position }\end{array}$ & $\begin{array}{l}\text { Duplicitous: Neither blatantly } \\
\text { anti-poor nor blatantly pro- } \\
\text { poor. Narrow sympathy limited } \\
\text { to staying evictions. Apathy by } \\
\text { actively disregarding shelter } \\
\text { right plea }\end{array}$ & Stealthy sympathy to AMC and GoG \\
\hline $\begin{array}{l}\text { Court's } \\
\text { discursive } \\
\text { devices }\end{array}$ & & $\begin{array}{l}\text { difficulties of AMC (by advanced cut- } \\
\text { off date), petitioners grievances } \\
\text { noted by GoG, matters seized by } \\
\text { GoG, GoG to take final decision }\end{array}$ \\
\hline
\end{tabular}

Being frustrated by a long unfruitful struggle, the slum community and JSM made one final appeal to the High Court, this time for the right to compensatory shelter for all citizens irrespective of the cut-off date, by requesting revoking of GoG orders of 2006 and 2010. The petition was made on grounds that GoG orders were "contrary to the law, reasons, justice, equity" and "passed mechanically without application of mind and much beyond the scope and powers of the state government." 29 The petition was disposed by High Court with the stand that "it will not interfere with GoG's final decision"30, once again revealing its anti-poor bias as well as its sympathy with the state. 
The outcome of this case has been that Ahmedabad continues to have most conservative cut-off date among Indian cities. Its enthusiasm for economic growth under a neoliberal paradigm, for which it has won many accolades nationally and internationally, has neglected the needs of the poor and its socalled "good" governance is primarily for the propertied middle class (Mahadevia, 2002, Shah, 2014). This has had serious implications on lives and well-being of slum dwellers who are evicted on a large scale. Homelessness and related vulnerabilities like loss of livelihood, access to health and education amenities, food insecurity and health risks and marginalisation, which have further impoverished evicted families are widely evident (Patel et al., 2015).

\subsection{The petition on right to basic services and commodification of public goods and services}

Slums in Ahmedabad are excluded from the purview of infrastructure projects on one hand and are vulnerable to evictions and demolitions on the other (Mahadevia, 2002). AMC has extended networks of basic infrastructure to most parts of the city including the erstwhile unserved areas of eastern Ahmedabad with a predominantly poor population. Thus in terms of extension of basic infrastructure networks there is no apparent attempt to exclude the areas of the poor (Mahadevia, 2002). However, barriers to obtain "legal" access to basic infrastructure such as water supply, sewerage and electricity were imposed on slum households which were not covered under slum upgrading programs. These barriers included the requirement to produce a Building Use (BU) certificate issued by AMC (certifying legality of a dwelling unit) in order for the dwelling unit to be connected to these services. Since slum dwellings are not constructed as per stipulations of the statutory development plan and building by-laws they are deemed illegal and are not issued BU certificate. For a slum household that was not covered under a slum upgrading program, obtaining legal access to basic services was therefore virtually impossible. After the neoliberal turn in mid 1990s slum upgrading programs were stopped and access to basic services for slum households was hampered.

Aggrieved by denial of access to basic services without BU certificate, residents of Ganeshnagar slum mobilized to form an association (GNES) through which they filed a petition in the High Court. The petition, filed against AMC and its subsidiary Ahmedabad Electricity Company, sought unhindered access to basic services, as a fundamental right enshrined in the right to life under article 21. It requested the Court to direct AMC to provide water, sewerage and electrical connections to slum dwellers without insisting for a BU certificate. ${ }^{31}$ The High Court showed sympathy towards poor and passed interim order directing AMC "to provide water, drainage and electrical connection to hutments dwellers or occupants of slums or chawls... without insisting for BU permission till the final order... however subject to the relevant Rules, Regulation and conditions laid down for obtaining such amenities." 32 Though on the face of it the Court 
appeared sympathetic to poor, it also allowed AMC the leeway of "rules, regulation..." in agreeing or disagreeing to provide basic services to the poor.

AMC acquiesced to the Court's order by passing a resolution to provide basic services to slum dwellers through a new scheme. The scheme implied that AMC would issue "No Objection Certificate (NOC) to those families residing in slums and having dwelling unit size less than 40 square $m t$ to get legal water, sewerage and electricity connections to their house" on payment of fees of INR 1500.33. The scheme hence was called "1500 NOC scheme". Though on the face of it the 1500 NOC scheme appeared to be a pro-poor response, it actually set difficult conditions for the poor to access services. First, the high fees of INR 1500 just to get a NOC from AMC. This was is in addition to the actual cost incurred for material for extension of services to their dwellings. Second was the harsh condition that water and sewerage connections would be provided only if the network and adequate quantity of water were available in their area. Third the scheme clarified that slum dwellers should have no illusion that NOC would make the construction legal or give them a legal ownership title. It is remarkable that such conditions and high fees are not imposed on a formal property owner applying for access to basic services. Thus discrimination on access conditions between the propertied and the unpropertied citizens was set. 
Table 16: Timeline and Evolution of the petition on right to basic services Timeline and Action by Actor

17/4/2001 Slum community GNES files Petition AMC. SCA 2716 of 2001. Petition states that AMC should provide water, sewerage and electricity connection to slum dwelling units without insisting for Building Use (BU) certificate (as a slum dwelling is not issued such a certificate by the concerned authority)

1/5/2001 HC interim order: Directs AMC to provide water and sewerage connection to slum dwellings without insisting for (BU) certificate BUT subject to relevant rules, regulation and conditions laid down for obtaining such amenities

8/8/2001 AMC-SC Resolution 543 passed. Announced a scheme (1500 NOC scheme) in which on payment of INR 1500 a slum dweller would be issued a "No Objection Certificate" by AMC for a legal water and sewerage connection to the dwelling unit.

1500 NOC scheme puts forward difficult conditions for slum dwellers such as high cost for NOC, connection to be given only if networks and adequate water is available in the area. NOC does not make their construction legal nor does it give a legal ownership title to slum dweller.

28/9/2001 AMC-General Board resolution numbered 449 approving the above resolution

19/10/2001 AMC submits Affidavit to HC briefing about action taken i.e formulation of 1500 NOC scheme.

$\mathrm{HC}$ interim order stating full bench required for decision on fees for NOC. Directing AMC to continue giving connections as per 1500 NOC scheme in the meantime.

24/3/2009 HC final order: Approves $1500 \mathrm{NOC}$ scheme provisions. SCA 2716 disposed

Actor's stance

Slum community mobilisation to claim right to basic services

Judiciary's apparent sympathy to poor and stealthy support to AMC by ordering conditional access AMC acquiesces to judicial interim order basic services are commodified as a high priced commodity with harsh conditions for access

AMC filed an affidavit reply to the Court explaining the launch of the 1500 NOC scheme. In return the High Court passed an interim order stating that full bench was required for a decision on fees for NOC but in the meantime AMC should continue giving connections by charging INR 1500. Eventually the High Court approved the fees and scheme and dismissed the case.

In this case both the Court and AMC showed a façade of sympathy for the poor. The Court affirmed the poors' right to basic services and AMC acquiesced by immediately formulating a unique scheme to provide basic services, delinked from land ownership or BU certificate. But underneath the sympathy was their neoliberal bias that the provision of services would not imply legal ownership of land they had encroached and that basic services would come at a high cost; thus reducing basic services to a commodity rather than a public good and slum dwellers to consumers of that commodity rather than citizens with right to a public good. Despite the precedence of a 1980 Supreme Court judgement in Ratlam Municipal Council vs. Vardichan case the Court allowed this stance of AMC and thus covertly supported its neoliberal pursuits. However, unlike the 
previous petition for right to shelter, this petition yielded a partial "victory" for slum dwellers in the sense that the Court and AMC both agreed to provide basic services to the poor, notwithstanding the tag of high cost, harsh terms and the underlying discriminatory basis.

\subsection{Conclusion}

We inquired whether Rajagopal's (2007) postulation that judiciary's stance on human rights is in congruence with the government's development ideology is valid in case of socio-economic rights of the unpropertied in Ahmedabad, known to aggressively pursue neoliberal development. Deconstructing the two petitions of slum dwellers in Ahmedabad, we show that the High Court perpetuates the States and local government's neoliberal growth agenda and their negative stance towards right to shelter and basic services of slum dwellers and thus validate Rajagopal's (2007) claim. However, unlike the Supreme Court and other state high courts which blatantly support the state's neoliberal agenda by rejecting socio-economic rights of the poor and by framing them as usurpers, encroachers or criminals (Ramanathan, 2006, Ghertner, 2008, Bhan, 2009, Dupont and Ramanathan, 2008), Gujarat High Court is not blatantly exclusionary. Rather, it allows AMC to be exclusionary without any censure. The High Court assumes a duplicitous stance of "stealthy sympathy" with AMC and of "not blatant apathy" towards the poor. It allows the poor to win small battles by halting evictions or ordering "conditional" access to basic services but simultaneously paves way for AMC to win war by actively disregarding the rights based discourse of the poor which could potentially hinder neoliberal development.

The right to basic services is commodified as a high cost commodity. The judiciary affirmed the right but also allowed AMC the leeway of "rules, regulation..." in agreeing or disagreeing to provide basic services to the poor. AMC acquiesced by formulating a program to provide basic services to poor, but with harsh conditions. Provision would not imply legal ownership of the land they had "encroached", water and sewerage connections would be provided only if the network and adequate quantity of water were available in that area, and basic services would come at a high price. Because of the neoliberal shift to "self-financing" and "cutting losses" of basic services, the right is reduced to a commodity and slum dwellers are reduced to consumers of that commodity, rather than treated as citizens with a right to public goods. Such harsh conditions and high fees for NOC are not imposed on a formal property owner applying for access to basic services. Thus discrimination on access conditions between the propertied and the un-propertied citizens is evident. Despite the precedence of a Supreme Court judgement requiring a local government to provide basic services to slum dwellers as a public good (Ratlam Municipal Council vs. Vardichan case in 1980) the High Court allowed AMC's stance, thus covertly supporting its neoliberal pursuits. 
The right to shelter is rejected as a fundamental right and compensatory shelter is limited to a meagre few who can prove residence prior to the cut-off date of 1976. AMC denies the right on grounds that "encroachers have no fundamental rights", and are an "obstruction to progress and development of the city", by means of beautification and infrastructure projects. AMC's rationale for restoring the 1976 cut-off date was in the "public interest", on the grounds that shifting the cut-off date to 1995 implies recognising right to compensatory shelter of more slum dwellers, "obstructing development of city", "causing liability of large land parcel (for providing compensatory shelter) and heavy financial burden on $\mathrm{AMC}^{\prime}$ and thus "hampering handing over developed land to private owners" and result in "encouraging encroachers", "increasing encroachments" and "(removal of encroachments would) giving rise to legal complications". "Removal" of "encroachments" is implied as an expected and inevitable event. The High Court actively disregarded precedence set by the Supreme Court's order in case of AMC vs. Nawab Khan Gulab khan case where it had upheld the right to shelter as a fundamental right under the right to life in article 21 . Thus by limiting itself and by actively disengaging from rights based discourse in the petition the Court stealthily assumed a prostate stance at expense of rights of the poor.

The social order of the city is altered by AMC's discursive framing of unpropertied poor as against "public" interest who are thus "othered" from the propertied "public" whose interest has to be protected. Such a discursive framing and the proclamation that "an encroacher does not have any fundamental right" is redefining terms of citizenship through construction of property-based citizenship. The non-propertied slum dwellers are viewed as sub-grade citizens with less rights than their citizenship implies and to whom the benefits of development and growth are not to be redistributed. The judiciary, rather than being an arbiter of justice, allows such a framing of socioeconomic rights of the un-propertied poor and differentiated terms of citizenship. Thus it shares neoliberal bias of the government.

The drawn-out claim making process (spanning over five and eight years in petitions for shelter and basic services respectively) does not lead to the "ordering" of institutionalisation of a permanent "invited space" by the judiciary from where the un-propertied citizens can negotiate their rights in routine governance processes rather than having to take judicial recourse each time they are aggrieved. Ward committees continue as "closed" spaces and area sabhas remain only on paper. When judicial process ends the negotiations end. The State (in policy) and local government (in practice) continue to resist "invited" spaces as they deem democratic deliberation inefficient and against "fast track development". 
Differentiated rights and terms of citizenship based upon property ownership is manifested on the spatial order of the city. Beautification and infrastructure projects such as riverfront and lake front development are realised at the expense of the un-propertied citizens (Figure 29 and 30 in section 6.2.3) with compensatory shelter offered to a meagre few (Figure 31 in section 6.2.3).

One more project aimed at "improving" the city's image -the Metro Rail Transit System (MRTS)- is now also being implemented through a Special Purpose Vehicle (SPV) Metro-Link Express for Gandhinagar \& Ahmedabad Company Limited (MEGA). The Development Plan of Ahmedabad, 2021 proposes Transit Oriented Development Zone (TOD) along MRTS and BRTS networks with a width varying from $250 \mathrm{mt}$ to $500 \mathrm{mt}$ on either side of the networks. TOD implies a higher Floor Space Index (FSI) and higher market values for the properties falling in the zone. It also implies eviction of slums within, either through market forces or through forced evictions, thus deepening sociospatial polarisation. The degree of disenfranchisement among the unpropertied due to cut-off date criteria varies which contributes to further sociospatial polarisation. Our research shows that about 46 per cent of slum population (based on a 2010 survey) is in various stages of displacement by such projects and only 20 per cent of the potential displacees are actually eligible for compensatory shelter. The economic losses to potential displacee families will be high as about 91per cent reside in permanent well-built dwellings, with 68 per cent having own water tap and 87per cent having own toilet, largely accessed as a high priced commodity. The risk of multiple forms of social impoverishment is additional. Further attention to this topic is given in chapter 5 . 


\section{Chapter 5}

\section{The risk of impoverishment in urban development- induced displacement and resettlement in Ahmedabad $^{3}$}

\footnotetext{
${ }^{3}$ This chapter is based on Patel S, Sliuzas R, Mathur N, 2015, "The risk of impoverishment in urban development-induced displacement and resettlement in Ahmedabad" Environment and Urbanization 27 231-256, doi : 10.1177/ 0956247815569128, available online March 9, 2015.

Also based on Patel, S and R Mandhyan (2014), "Impoverishment assessment of slum dwellers after off-site and onsite relocations: A case of Indore", Commonwealth Journal of Local Governance 15, http://dx.doi.org/10.5130/cjlg.v0i0.4065, available online June 15, 2014.
} 


\begin{abstract}
Processes of globalization and neoliberal reforms of local governance in Indian cities have created distinct patterns by reshaping the physical and social landscapes of India's cities, triggering contestations between the privileged and the dispossessed. This paper addresses the consequences for poor households of mega-urban renewal and infrastructure projects and the processes of displacement and resettlement in Ahmedabad, India. The findings indicate that the displaced poor households have been further impoverished in the course of current practices as a result of limited attention to the risk of impoverishment both in policy and in local government practices. Contrary to the state's rhetoric of inclusive governance, the urban poor are completely excluded from planning for infrastructure development and resettlement processes, leading to a lack of understanding of their needs by the state and their subsequent impoverishment after resettlement.
\end{abstract}

Keywords: community exclusion, development-induced displacement and resettlement (DIDR), impoverishment risk, India, policy rhetoric, rhetoricreality gap, slums 


\subsection{Introduction}

Contemporary urban development and city-making in India has been largely based on the national government's flagship investment program, the Jawaharlal Nehru National Urban Renewal Mission (JNNURM), India's largest single infusion of public funds to urban local governments for slum upgrading, transport and other infrastructure. The objectives were both rapid economic growth through large-scale infrastructure projects and the inclusion of the urban poor in economic growth. Within JNNURM, the Ministry of Urban Development (MoUD) has focused on infrastructure investment through its Urban Infrastructure and Governance (UIG) program; the Ministry of Housing and Urban Poverty Alleviation (MHUPA) focused on integrated development of slums through the Basic Services for Urban Poor (BSUP) program. However, this two-pronged approach belies a strategy of deliberate confusion and the dispersion of accountability and responsibility (Mahadevia, 2011).

Under the UIG program, city morphology and functions were being altered by forced land acquisition for infrastructure projects such as road widening, the Bus Rapid Transit System (BRTS), Mass Rapid Transit System (MRTS), flyovers, and waterfront-based development, causing large-scale displacement of poor households living in informal self-built neighbourhoods, as witnessed in all major cities (George and Nautiyal, 2006 ) including New Delhi, Mumbai, Chennai, Ahmedabad, Hyderabad, Visakhapatnam and ironically also Kolkata. ${ }^{34}$ Displaced households that could prove their "eligibility" in theory got compensatory shelter, mainly under BSUP; others were left to fend for themselves. "Eligibility" criteria are based on state-approved documentary residence proof for an arbitrary cut-off date that varies from city to city. In Mumbai general cut-off date is 1995, and for special cases the 2001 date is allowed; for Delhi the cut-off date has moved from 1990 to 1997 to 2004, and most recently to 2007 (Bhan et al., 2014), for Ahmedabad the general cut-off date is 1976 and for Sabarmati Riverfront Development (SRFD) project December 2002 cut-off is allowed.

Contrary to JNNURM rhetoric, limited space and resource have been allocated for the urban poor (WGHR, 2012). BSUP resettlement projects are often implemented in city peripheries, distant from peoples' workplaces, schools and hospitals and thus not meeting the criteria of adequate shelter (WGHR, 2012). Contrary to the objective of providing in-situ basic services to poor households, in most cities BSUP projects have funded off-site rehabilitation housing for project-affected people whose replacement housing should have been budgeted for within the profit-making projects that displaced them, thereby depriving the intended urban poor beneficiaries of outreach (Mahadevia et al., 2013). The Final Monitoring Report for JNNRUM indicates the ineffectiveness of BSUP (MHUPA, 2014), showing that only 52 per cent of the almost one million approved dwelling units were constructed and only 36 per cent of those 
approved were actually occupied. A low level of occupancy, attributed to the isolated and inhospitable locations of BSUP housing projects, is reported across all the cities, including Bengaluru (43 per cent occupancy) and Greater Hyderabad (10 per cent occupancy)(Mahadevia et al., 2013).

Within this context this research examines the consequences of socio-spatial polarisation through urban renewal and infrastructure projects for the resettled poor households as it occurred in Ahmedabad, India. Though BSUP will come to a close in April 2015, it paved the way for Rajiv Awas Yojna (RAY) in 2013, which is again a central government subsidised program for provision of housing, improvement of basic civic infrastructure and social amenities in-situ or in relocated slum sites. The lessons from BSUP should contribute towards restructuring of RAY so that better outcomes can be achieved.

\subsubsection{Understanding Development-Induced Displacement and Resettlement in India}

The state generally rationalizes concerns around large infrastructure development with rhetoric about the greater good, maintaining that the rehabilitation of the displaced to prior levels of wellbeing can be achieved, thereby justifying avoidable ills. Critics of displacement posit that those displaced are inevitably exposed to multiple impoverishments, and many researchers have demonstrated social, economic and cultural consequences, raising issues of social justice and equity (Cernea, 2000b, Cernea, 2000a, Fernandes, 1991, Mathur, 1998, Downing, 1996). Displacement in developing countries mostly affects people living below the poverty line, rendering the poor even more impoverished (Cernea, 2000b, Cernea, 2000a, Fernandes, 1991, Mathur, 1998).

Cernea (2000) proposes eight interlinked forms of impoverishment (landlessness, homelessness, joblessness, marginalization, food insecurity, loss of access to common property, morbidity and mortality, and social disarticulation) in his Impoverishment Risks and Reconstruction (IRR) model. These have been empirically reconfirmed in the past two decades (Mathur, 1998, Bartolome et al., 1999, DeWet, 2006 , Fernandes, 1991), largely in the context of rural displacements. Other forms have also been identified, including psychological marginalization, loss of access to services, schooling and civil rights. "Impoverishment" is defined by Cernea (2000b) to refer to situations in which people's welfare and livelihoods worsen as a result of a specific intervention; and "risk" as the possibility that adverse effects such as losses, destruction, functionally counterproductive impacts, and deprivations of future generations will be triggered. Impoverishment risks, he argues, can be controlled through a policy response that mandates participation of and information transparency to potentially affected communities from the onset. Dysfunctional communication between decision-makers and affected 
communities and the consequent lack of understanding of the latter's needs and aspirations have been emphasized as the key cause of resettlement failure and impoverishment of displacees (Bartolome et al., 1999, Cernea, 2000a).

Most studies on Development Induced Displacement and Resettlement (DIDR) have used Cernea's framework in the context of rural displacement. Research on urban DIDR, relatively unstudied (Bartolome et al., 1999)until the last decade, is currently emerging, especially in Indian context, in three areas: governance aspects and displacement processes, implications of resettlement for displacees, and both of these topics in the context of JNNURM and BSUP.

Most of this research focuses on displacement and governance. Ramanathan discusses the role of judiciary in effecting large-scale demolitions and displacement of urban poor in the process of "cleaning up" Delhi and also in emerging notion of "illegality" of slums (2006:3193). Desai (2012b) discusses how authorities in Ahmedabad officially represented their urban mega-project, SRFD, as inclusive despite profoundly disregarding issues of social justice. Dupont (2008)discusses creation of new squatters and densification of existing slums after displacements in Delhi. A small body of research is emerging related to implications for those displaced. The research of the Society for the Promotion of Area Resources Centres (SPARC) on Mumbai, where about 60,000 people living along railway tracks were resettled to a site about four stations away, describes this as a successful resettlement that did not impoverish the displaced (Patel et al., 2002:159). The research attributes success to realignment of roles among state agencies, NGOs and the community, with the latter fully involved in designing, implementing and managing the resettlement. However, this case is exceptional; most evidence from Indian cities points to negative consequences of displacement. MenonSen and Bhan's New Delhi research indicates how eviction and resettlement related to neoliberal projects such as Commonwealth Games eroded socioeconomic rights and undermined livelihoods of 3,000 resettled families, marooning them in a distant site and leaving them in state of "permanent poverty" (2008:179). HRLN's (2006)compiled evidence from many Indian cities points to demolition sprees and de-housing of unpropertied poor under various mega-infrastructure projects with minimal support for the displaced poor. The extent of the impact is not indicated in qualitative or quantitative terms.

Both the governance aspects of displacement processes and implications for urban poor are increasingly discussed in the context of JNNURM and BSUP. Research shows that, although large-scale displacements are evident across Indian cities, only "meagre" rehabilitation has occurred since JNNURM began (Mahadevia et al., 2013, Patel, 2013), largely through BSUP. In the absence of appropriate guidelines for Resettlement and Rehabilitation in most cities, 
BSUP has been implemented through off-site rehabilitation projects in isolated city peripheries, resulting in poor access to jobs and amenities. Through extensive research of BSUP implementation in 11 cities, Patel et al indicate "increased impoverishment of the poor emerging from the exclusion of slum dwellers in design, planning and decision-making" (2013:1).

\subsubsection{Development-Induced Displacement and Resettlement in Ahmedabad}

Adding to this emerging body of research on urban DIDR in India, this paper considers the consequences of neoliberal beautification and infrastructure projects that caused major displacement and resettlement of few mainly under JNNURM's BSUP for the displaced households. We specifically seek to answer three questions.

- Are the poor further impoverished after resettlement?

- Are there gaps in policy pertaining to impoverishment risks? And where policy exists, are there gaps between policy rhetoric and the reality of practice by local government?

- Was there effective community participation in critical decisions related to displacement and resettlement in Ahmedabad?

Ahmedabad has a legacy of Gandhian values, a strong economic base of textile industries (until their collapse in the mid-1980s), and vigorous Civil Society Organizations (CSOs), initiated by Gandhi through establishment of the Textile Labour Association. For many years, Ahmedabad nurtured inclusive and peaceful development, with a local government functioning as a welfare state in collaboration with CSOs. Two important products of the partnership were the Slum Networking Program (SNP), focused on in-situ upgrading of slums and granting of de facto tenure rights(Dutta, 2000), and the Nirmal Gujarat Sanitation Plan focused on large-scale provision of basic services to the poor at rates much higher than in other cities of India (PAS, 2013). This history stands in sharp contrast to Ahmedabad's response to globalization and neoliberal reforms since 2000, with rapid economic growth, large-scale infrastructure projects, the consequent displacement of the urban poor from prime locations in the city, and the infringement of social justice(Mahadevia, 2002). The communal riots of 2002 between the two major communities, Hindus and Muslims, formed a significant part of this remaking of the city. They were the result of a perceived threat of invasion of the Muslim "other" in the city's life spaces, shrinking rapidly under the effects of globalization and collapse of the textile industry (Mahadevia, 2002). As a consequence, the first large-scale displacement was of Muslim families in 2002-03 from the riotaffected areas in the city core to other parts of the city.

Simultaneously, Ahmedabad's neoliberal vision of being a world-class city paved the way for many iconic beautification and infrastructure projects such 
as SRFD, Kankaria Lakefront Development (Figures 15), BRTS, MRTS, flyovers and road projects, and reclamation of commons inhabited by the urban poor. Such projects have caused large-scale displacement of the urban poor to the city's periphery. Estimates are that about 28,000 houses in 47 slums were demolished from 2003 to 2010, followed by another 1,000 houses from 20 slums along the Sabarmati riverfront in May 2011(Concerned Citizens of Ahmedabad, 2010). The first resettlement allotment was offered only in 2005 on a "site and services" site on outskirts of the city, adjacent to city's solid waste disposal site. The Ahmedabad Municipal Corporation (AMC) claimed that permanent arrangements would be provided within 18 months ${ }^{35}$, but many households continued to reside on the interim site seven years after their resettlement.

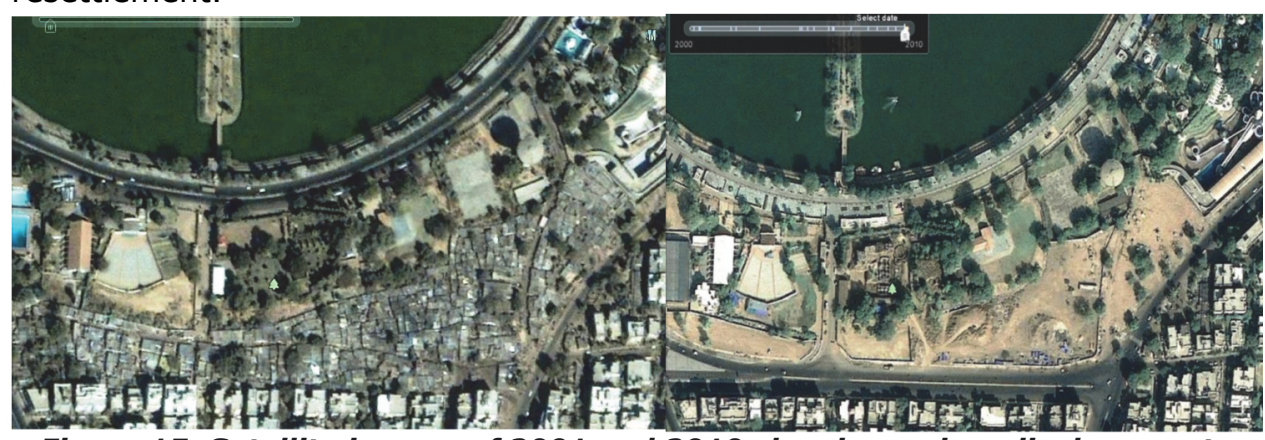

Figure 15: Satellite images of 2001 and 2010 showing a slum displacement under Lakefront Development, Ahmedabad

Source: Google Earth 2001 and 2010

Though labelled a "site and services" option 36 the site was undeveloped and had only a few common water taps and a block of common-use toilets. BSUP construction commenced in 2007 and in 2009 the first dwelling units were allotted to SRFD project-affected people by order of the High Court of Gujarat. Desai (2012b) explains that AMC implemented eviction and resettlement in such a fragmentary manner in order to limit community mobilization and resistance and consequent judicial intervention.

\subsection{Methods}

For the research we collected and analyzed primary and secondary data on policy and effects of DIDR on affected households. We conducted semistructured interviews of key AMC personnel and civil society actors; and analysed the BSUP guidelines, BSUP project appraisal toolkit and report, SRFD master plan, and media reports were to construct the official claims related to resettlement. We analyzed the master plan of SRFD, as it caused major displacements (Table 18), and BSUP policy as it is relevant to resettlement. Because data on actual resettlement of displaced households were not publicly available when research commenced in May 2011, we conducted a household 
survey from June to August 2011 using a two-step process. Of 28,000 households (approximate figure as there was no consensus) displaced from 2003 to 2010, 3275 were identified as resettled on BSUP sites and 609 on the interim resettlement site (site and services) at Piplaj. From an additional 1,000 houses demolished in May 2011, only 670 households could be traced.

Table 17: Projects that caused displacement

\begin{tabular}{|l|l|l|}
\hline & $\begin{array}{l}\text { Distribution } \\
(\%)\end{array}$ & $\begin{array}{l}\text { Households No.s } \\
\text { (in Sample) }\end{array}$ \\
\hline Total Households (Hhs) & $\mathbf{1 0 0 \%}$ & $\mathbf{3 9 6}$ \\
\hline Hhs displaced under SRFD & $61 \%$ & 241 \\
\hline Hhs displaced Lakefront Development & $19 \%$ & 77 \\
\hline Hhs displaced BRTS & $18 \%$ & 71 \\
\hline Hhs displaced DP Road widening & $2 \%$ & 7 \\
\hline
\end{tabular}

Table 18: Sample framework (from primary reconnaissance survey, June

\begin{tabular}{|l|l|l|l|l|}
\hline Site & $\begin{array}{l}\text { Dwellings/ } \\
\text { Plots } \\
\text { constructed }\end{array}$ & $\begin{array}{l}\text { Dwellings } \\
\text { allotted }\end{array}$ & $\begin{array}{l}\text { Dwellings } \\
\text { occupied }\end{array}$ & $\begin{array}{l}\text { Sample } \\
\text { No.s } \\
(\mathbf{1 0} \%)\end{array}$ \\
\hline
\end{tabular}

A : Direct resettlement on BSUP site

\begin{tabular}{|l|l|l|l|l|}
\hline BSUP Isanpur & 384 & 197 & 172 & 17 \\
\hline BSUP Vadaj & 576 & 465 & 395 & 39 \\
\hline BSUP Rakhial & 704 & 479 & 422 & 42 \\
\hline BSUP Bage-e-firdosh & 672 & 472 & 459 & 46 \\
\hline BSUP Odhav & 320 & 164 & 121 & 12 \\
\hline BSUP Vatva & 2768 & 674 & 533 & 51 \\
\hline Sub Total for A & $\mathbf{5 4 2 4}$ & $\mathbf{2 4 5 1}$ & $\mathbf{2 1 0 2}$ & $\mathbf{2 0 8}$ \\
\hline
\end{tabular}

B. Resettlement on BSUP site from interim site

\begin{tabular}{|l|l|l|l|l|}
\hline BSUP Vatva & 2224 & 824 & 615 & 61 \\
\hline Sub Total (A+B) & $\mathbf{7 6 4 8}$ & $\mathbf{3 2 7 5}$ & $\mathbf{2 7 1 7}$ & $\mathbf{2 6 9}$ \\
\hline
\end{tabular}

C. Long duration resettlement on interim site

\begin{tabular}{|l|l|l|l|l|}
\hline Interim Site & 1500 & & 609 & 60 \\
\hline D. No resettlement : continue on demolished site \\
\hline Demolished sites & & & 670 & 67 \\
\hline Total (A+B+C+D) & & & 3996 & 396 \\
\hline
\end{tabular}




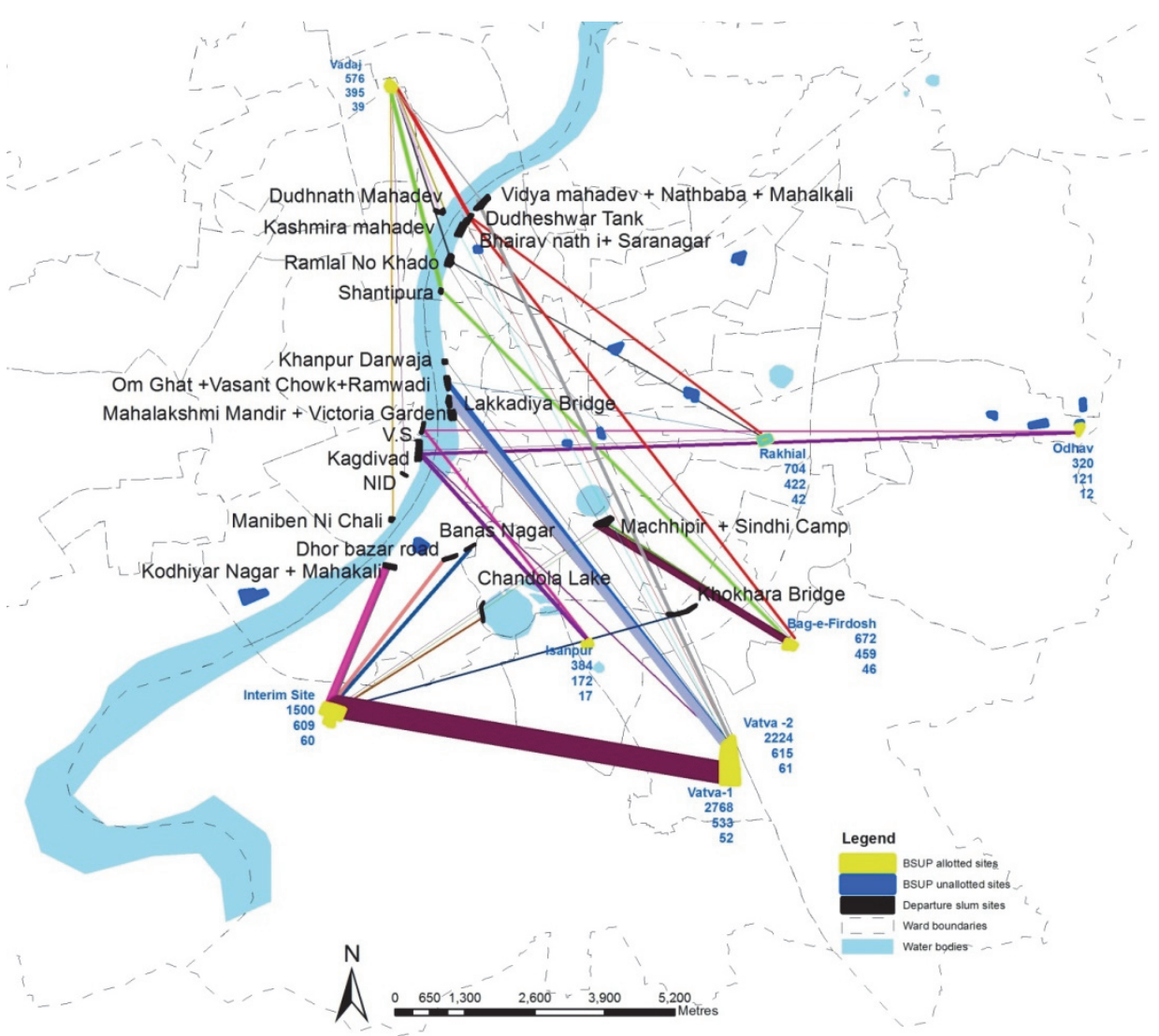

Figure 16: Displacement and resettlement patterns on interim and permanent (BSUP) sites and sample distribution

Note: In above figure the colour of a line indicates the displacement from a specific slum to resettlement site and the thickness indicates the proportion of households displaced from a slum to resettlement site.

For indicators to assess impoverishment, Cernea's impoverishment risks were reinterpreted based on the context of Ahmedabad (Table 20). 
Table 19: Specific indicators employed in Ahmedabad, based on Cernea's impoverishments risks

\begin{tabular}{|c|c|}
\hline $\begin{array}{l}\text { Impoverishment } \\
\text { Form }\end{array}$ & Specific indicators \\
\hline Landlessness & $\begin{array}{l}\text { Loss of land reinterpreted as distant relocation leading to } \\
\text { increased distances to livelihood, social amenities, market } \\
\text { place etc., loss of job, loss of access to opportunities etc. }\end{array}$ \\
\hline \multirow[t]{5}{*}{ Joblessness } & Sustained Loss of Job \\
\hline & Loss of working days \\
\hline & Increased distance and transport cost to work \\
\hline & Increased monthly expenditure as percentage of income \\
\hline & Increased Debt \\
\hline \multirow[t]{4}{*}{ Homelessness } & Loss of Assets \\
\hline & Cost of transporting the assets \\
\hline & Cost of reconstruction on new plot \\
\hline & $\begin{array}{l}\text { Loss of groups cultural space resulting in sense of } \\
\text { placelessness }\end{array}$ \\
\hline \multirow[t]{5}{*}{ Marginalisation } & Lower socio-economic status in new location \\
\hline & Coercive displacement \\
\hline & Subjugation of vulnerable groups i.e. women and minorities \\
\hline & Hostility from host community \\
\hline & Loss of standing in community \\
\hline \multirow[t]{4}{*}{ Health Risk } & Lack of access to safe drinking water and sewerage \\
\hline & Inadequate solid waste management \\
\hline & Decreased access to Fair Price Shops \\
\hline & Decreased access to primary and higher order health facilities \\
\hline \multirow{4}{*}{$\begin{array}{l}\text { Loss of access to } \\
\text { common } \\
\text { facilities } \\
\text { (Common } \\
\text { Property } \\
\text { Resources } \\
\text { reinterpreted) }\end{array}$} & Decreased access to education and health services \\
\hline & School dropout ratio and Loss of school attendance days \\
\hline & $\begin{array}{l}\text { Increased distance, travel cost and monthly cost for education } \\
\text { vis a vis income }\end{array}$ \\
\hline & Lowered access to hospitals in emergencies \\
\hline \multirow{5}{*}{$\begin{array}{l}\text { Social } \\
\text { Disarticulation }\end{array}$} & Fragmentation of social units \\
\hline & Dissatisfaction and discord with new community \\
\hline & Loss of community institutions \\
\hline & Application for transfer to reunite with kin \\
\hline & Alienation and abuse of common resources \\
\hline
\end{tabular}

The data related to conditions of beneficiaries before and after resettlement were captured quantitatively and qualitatively in the questionnaire from the recall of the residents. Recall of such quantitative measures as distance, income and loss of assets was triangulated through other means. The recall of qualitative data such as community bonding, feelings of inclusion, etc. was solely based on memory. 
To corroborate survey findings, we conducted semi-structured interviews of civil society actors, focus group discussions with the displaced communities, field observations and documentary analysis of media reports, judicial rulings, academic reports and official AMC notices to displacees at various stages of displacement. Field observations were carried out from May to December 2011 on slum sites which were to be displaced, on BSUP sites, the interim resettlement site, and still-occupied post-demolition slum sites.

\subsection{Results}

This section discusses our findings related to the gap between policy and the reality of impoverishment. For each form of impoverishment, whether based on Cernea's (2000b) IRR framework or a new emergent form, we discuss the policy claims and actual practice as revealed through our research.

\subsection{1 a. Landlessness}

Land is the principal foundation for people's livelihoods, commercial activities, social networks and productive systems, and its expropriation is a principal form of impoverishment and de-capitalization(Cernea, 2000b). In the urban context, the key importance of land is its location with respect to opportunities for livelihoods, social networks, and amenities for health and education.

Policy: In the BSUP Detailed Project Report (DPR) appraisal checklist, there was a perfunctory reference to relocation distance that inquired "Is the new site in proximity to the original site/work-place?" (Government of India, 2009a). However, "proximity" was not clearly defined and remedial measures were not mentioned. The SRFD master plan, (EPC, 1998) which was not in public domain, underlined the need for a close relationship between places of residence and work, rejected displacements of urban poor in the riverbed to distant sites, and earmarked three relocation sites within three $\mathrm{km}$ of displaced households' former homes (Desai, 2012b). AMC claimed that "to the extent possible the displaced households are being resettled within the same ward. ${ }^{137}$

Reality: Contrary to these claims, Figure 16 reveals that no surveyed household was resettled within the same ward and only 3 percent were resettled within $3 \mathrm{~km}$ of their departure slum. Mean relocation distance varied from $4.63 \mathrm{~km}$ (interim site) to $8.77 \mathrm{~km}$ (BSUP sites), as shown in Figures 17 and 18. Households displaced twice were subject a mean of $15 \mathrm{~km}$ of displacement from the departure slum over a period of two to six years. 


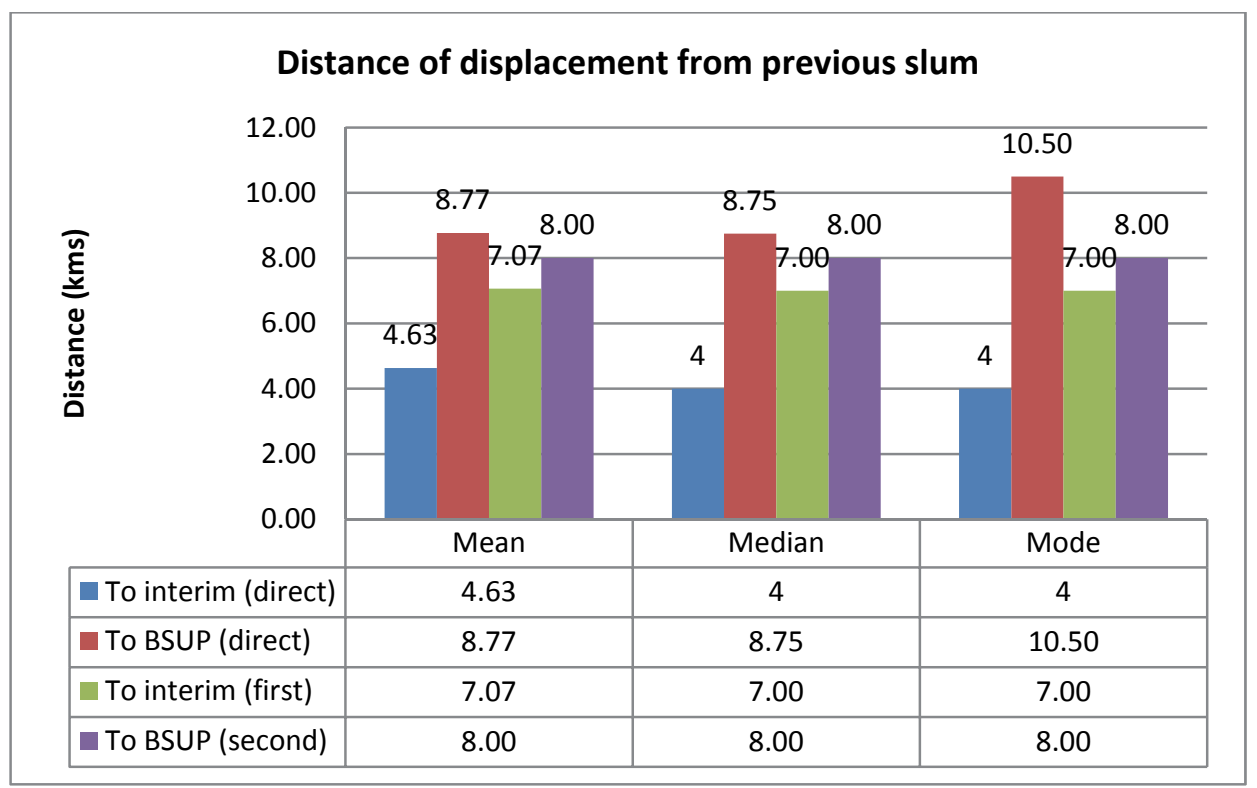

Figure 17: Average, median and mode of distance of relocation of slum household from departure slum to interim and BSUP sites 


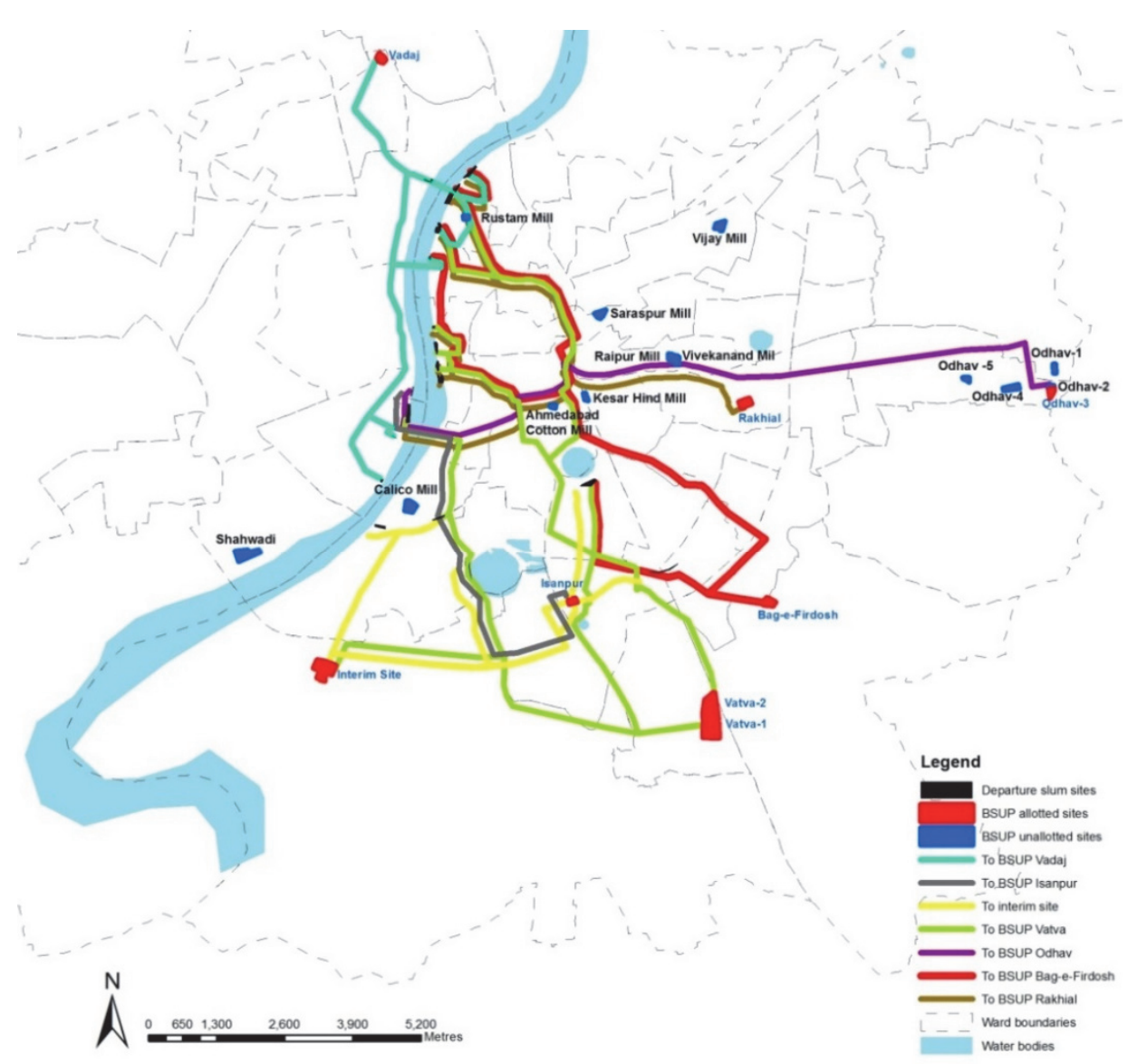

Figure 18: Mapping of pattern and distance of relocation of displaced households to interim and BSUP sites

Travel distance to school increased by an average of $1.2 \mathrm{~km}$, and cost increased by 50 percent. Access to public hospitals was hampered due to increased distance and inadequate access to public transport. Those households that stayed on demolished sites were the worst off and many resorted to begging. Our findings thus show a trend towards greater impoverishment as a result of more distant, off-site resettlement.

There was actually scope for AMC to resettle a large number of displaced households within the same ward or within $3 \mathrm{~km}$ as promised. Our analysis shows one BSUP site to be within $4 \mathrm{~km}$ of most of the evicted slums. For example, about 164 households from two slums in the west riverbed were relocated early in 2011 to the Odhav BSUP site, $14.5 \mathrm{~km}$ away on the eastern periphery of the city, even though two fully built BSUP sites were located within $6 \mathrm{~km}$ of these two slums, with over 1,000 unallotted units. 


\subsection{2 b. Joblessness}

Loss of employment, a major issue linked to displacement, can be temporary or sustained. Even those who find employment after relocation may not find jobs matching their skills and former income levels. If the distance and cost of travel to work increases significantly, reduced earnings and higher expenditures may lead to debts and aggravate impoverishment.

Policy: BSUP policy and guidelines did not include support to the displaced on livelihoods or capacity and skill building, but do state that "Convergence of health, education and social security schemes for the urban poor" could be an admissible component within BSUP (Government of India, 2009b). This implies that existing schemes in a city or state could be supported under BSUP. However, such schemes were not found in any of Ahmedabad's BSUP sites, pointing to a lack of policy attention for this aspect of impoverishment in Ahmedabad.

Reality: Our survey shows that after dispossession, 14 percent of workers remained chronically unemployed at the time of the survey and 38 percent had lost income days, with an average loss of 28 days (Table 20). Households that endured two relocations suffered the most. When relocated to the interim site, 26 percent were unemployed; when resettled at a BSUP site, after an average of four years, 20 percent remained chronically unemployed. The inability to find work suiting their skills, loss of clientele in a new location and the need to spend time for reconstruction and adjustment at the new site were cited as reasons for sustained unemployment. For those who found employment, the distance to work, as noted, increased almost twofold by an average of 3.74 $\mathrm{km}$. Both the interim and BSUP sites are on the city's periphery, and public transport, in terms of frequency, is inadequate. Many people (average 13 per cent ) shifted from cycling and public transport to private forms of motorized travel and the average travel expenditure to work increased by 50 per cent (Table 21). The cumulative effect is that monthly expenditure increased sharply relative to income and savings were rendered negligible. A third of households in the interim site and a quarter in BSUP sites had debts of over US\$ 500, and impoverishment had set in. 
Table 20: Loss of employment and income days after displacement

\begin{tabular}{|l|l|l|l|}
\hline & $\begin{array}{l}\text { \% of workers } \\
\text { who lost } \\
\text { employment }\end{array}$ & $\begin{array}{l}\text { \% of workers } \\
\text { who lost } \\
\text { income days }\end{array}$ & $\begin{array}{l}\text { Average loss of } \\
\text { income days }\end{array}$ \\
\hline Interim Site & $16 \%$ & $31 \%$ & 67 \\
\hline BSUP Site & $10 \%$ & $53 \%$ & 22 \\
\hline Interim Site(at first) & $26 \%$ & $18 \%$ & 35 \\
\hline $\begin{array}{l}\text { BSUP Site (after } \\
\text { Interim) }\end{array}$ & $20 \%$ & $17 \%$ & 9 \\
\hline Demolished Site & $5 \%$ & $30 \%$ & 25 \\
\hline Overall & $\mathbf{1 4 \%}$ & $\mathbf{3 8 \%}$ & $\mathbf{2 8}$ \\
\hline
\end{tabular}

Table 21: Increase in distance to work and travel to work expenditure after

\begin{tabular}{|l|l|l|l|l|}
\hline & $\begin{array}{l}\text { Average } \\
\text { increase in } \\
\text { distance to } \\
\text { work (Km) }\end{array}$ & $\begin{array}{l}\text { \% increase } \\
\text { in distance } \\
\text { to work }\end{array}$ & $\begin{array}{l}\text { \% work } \\
\text { trips shifted } \\
\text { to private } \\
\text { and } \\
\text { motorized } \\
\text { mode of } \\
\text { transport }\end{array}$ & $\begin{array}{l}\text { \% increase } \\
\text { in travel } \\
\text { expenditure } \\
\text { to work }\end{array}$ \\
\hline Interim Site & 4.00 & 154 & 23 & 58 \\
\hline BSUP site & 5.14 & 281 & 16 & 66.3 \\
\hline $\begin{array}{l}\text { Interim Site (at } \\
\text { first) }\end{array}$ & 4.16 & 121 & 23 & 33.6 \\
\hline $\begin{array}{l}\text { BSUP (after } \\
\text { interim) }\end{array}$ & 0.90 & 12 & -3 & 23 \\
\hline Demolished Site & 0.48 & 22 & 0 & 21 \\
\hline Overall & 3.74 & 175 & 13 & 50 \\
\hline
\end{tabular}

\subsection{3 c. Homelessness}

Loss of shelter means loss of physical assets; cost of transporting assets; cost of reconstruction on a new site; increased deprivation of water, sanitation, education and health services; and loss of cultural space and identity, leading to alienation, status deprivation and impoverishment (Cernea, 2000b).

Policy: In urban projects that have induced displacement, claims of universal compensation of house for house have not been made and budgeted in the projects, and the resettlement of "eligible" households is therefore offloaded onto BSUP. There is thus a clear gap in policy pertaining to homelessness.

Reality: Not all of those displaced with eligibility documents were allotted BSUP dwelling units or an interim site plot; nor did all allottees have eligibility documents. Such inconsistencies point to possible exclusionary and 
discriminatory practices. Homelessness was witnessed in two categories: households that endured long stays at the interim site and those that, excluded from resettlement, continued to reside on the demolition site. The former had to construct a new house on the interim site at their own cost; compensation from AMC was less than US $\$ 100$ (Indian rupees (INR) 5,000) against an average cost per household of US $\$ 1,087^{38}$ (INR 54,362) (Table 22). One third of households incurred debts to cover their costs. On the interim site, more than 80 percent lived in temporary, structurally unsafe shelters (Figure 19); most of them previously had a permanent home that they had occupied for 23 years on average.

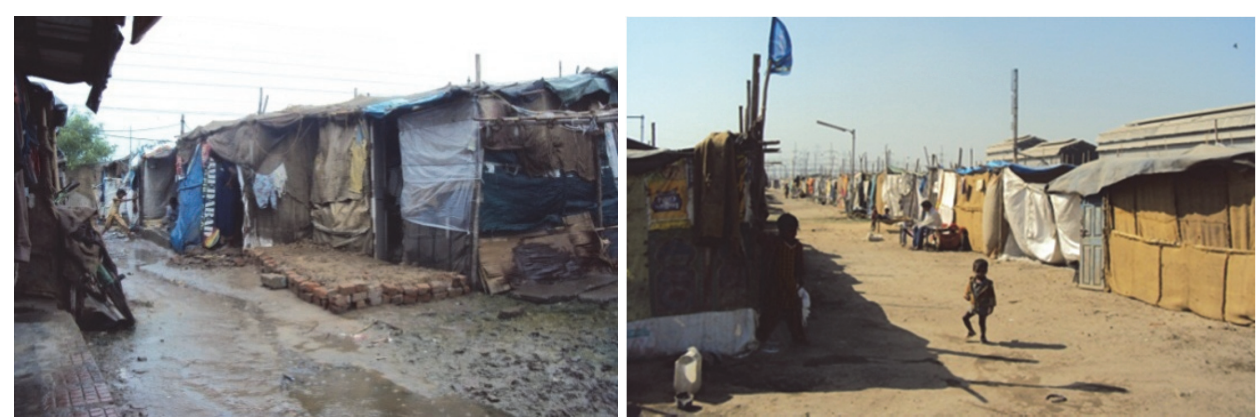

Figure 19: Quality of interim site and its services and shelter

Table 22: Loss of shelter and associated losses for displacees on interim site and demolished sites

\begin{tabular}{|l|l|l|l|l|l|}
\hline & $\begin{array}{l}\text { \% } \\
\text { households } \\
\text { with } \\
\text { permanent } \\
\text { and semi- } \\
\text { permanent } \\
\text { houses in } \\
\text { departure } \\
\text { slum }\end{array}$ & $\begin{array}{l}\text { Average } \\
\text { Value of } \\
\text { lost } \\
\text { assets } \\
\text { (INR) }\end{array}$ & $\begin{array}{l}\text { Average Cost } \\
\text { of } \\
\text { transporting } \\
\text { assets (INR) }\end{array}$ & $\begin{array}{l}\text { Average Cost of } \\
\text { reconstructing } \\
\text { on interim/ } \\
\text { demolished } \\
\text { site (INR) }\end{array}$ & $\begin{array}{l}\text { Average } \\
\text { total } \\
\text { Cost } \\
\text { (INR) }\end{array}$ \\
\hline Interim Site & 69 & 21449 & 1888 & 31025 & 54362 \\
\hline $\begin{array}{l}\text { Demolished } \\
\text { Site }\end{array}$ & 48 & 19779 & 0 & 2446 & 22230 \\
\hline Overall & $\mathbf{5 8}$ & $\mathbf{2 0 5 6 8}$ & $\mathbf{8 9 1}$ & $\mathbf{1 5 9 4 8}$ & - \\
\hline
\end{tabular}

Displacement to the interim site has also meant increased deprivation of water, sanitation, education and health services. According to a civil rights activist, "The water supply is irregular. Sometimes there is no supply even for two days. Water taps are dirty and contaminated water is being supplied in the area, with no cleanliness" (Dave, June 21, 2012 ). For many households that have endured seven years at this interim site, loss of shelter has become sustained rather than transitory impoverishment. 
For households that continued to reside on demolished sites, deprivation was even worse; they squatted on open land on or near the demolished site, without permanent shelter or access to water and sanitation. Municipal guards patrolled the sites to prevent re-occupation, adding to feelings of insecurity. The average cost to these households from the loss of assets was US\$ 444 (INR 22,230), and they were denied relief compensation for transfer or reconstruction elsewhere.

\subsection{4 d. Loss of access to community facilities (education and health)}

Access to common property, listed by Cernea (Cernea, 2000b), is interpreted in the urban context of Ahmedabad as access to facilities such as public schools, public health centres and public hospitals. Loss of access to such facilities may lead to significant deterioration in the economic and human wellbeing of the resettled.

Policy: Claims of access to lower order community facilities were perfunctory in the BSUP Detailed Project Report appraisal checklist, which inquires whether provisioning for a community centre, community primary health care centre, primary education centre, parks and open spaces has been made in the BSUP project(Government of India, 2009a). There are no claims in BSUP guidelines regarding access to higher order community facilities such as Public Hospitals.

Reality: Our survey shows that a municipal primary school has been constructed near only one BSUP site (Vatva), where about 5,000 dwellings have been constructed. Other smaller BSUP sites managed with only a primary education centre for children up to seven years of age. The interim site, designed for 1,500 households, had only a primary education centre in 2012, a full seven years after it was established. We found that on a few BSUP sites primary education centres were not even fully functional (Table 23). The buildings were constructed according to guidelines, but owing to the lack of personnel or institutional arrangement, services were absent or minimal. 
Table 23: Status of community facilities on BSUP sites (primary survey August

\begin{tabular}{|c|c|c|c|c|c|c|c|}
\hline $\begin{array}{l}\text { BSUP } \\
\text { site }\end{array}$ & \begin{tabular}{|l|} 
RWA \\
formed
\end{tabular} & $\begin{array}{l}\text { Primary } \\
\text { Health } \\
\text { Centre } \\
\text { constructed }\end{array}$ & $\begin{array}{l}\text { Primary } \\
\text { Health } \\
\text { Centre } \\
\text { functioning }\end{array}$ & $\begin{array}{l}\text { Primary } \\
\text { Education } \\
\text { Centre } \\
\text { constructed }\end{array}$ & $\begin{array}{l}\text { Primary } \\
\text { Education } \\
\text { Centre } \\
\text { functioning }\end{array}$ & $\begin{array}{l}\text { Primary } \\
\text { School } \\
\text { constructed }\end{array}$ & $\begin{array}{l}\text { Primary } \\
\text { School } \\
\text { functioning }\end{array}$ \\
\hline Isanpur & No & \begin{tabular}{|l|} 
Yes \\
\end{tabular} & No & Yes & No & No & No \\
\hline Wadaj & \begin{tabular}{|l} 
Under \\
process
\end{tabular} & Yes & Yes & Yes & Yes & No & No \\
\hline Odhav & $\begin{array}{l}\text { Under } \\
\text { process }\end{array}$ & No & No & No & No & No & No \\
\hline Rakhial & \begin{tabular}{|l|} 
Under \\
process
\end{tabular} & Yes & $\begin{array}{l}\text { Yes (Doctor } \\
\text { visits for } 2 \\
\text { Hrs/day) }\end{array}$ & Yes & Yes & No & No \\
\hline Vatva A & \begin{tabular}{|l|} 
Under \\
process
\end{tabular} & Yes & $\begin{array}{l}\text { Mobile Health } \\
\text { Van }\end{array}$ & Yes & Yes & \multirow{2}{*}{$\begin{array}{l}\text { Yes (in } \\
\text { common for } 2 \\
\text { sites) }\end{array}$} & \multirow[t]{2}{*}{ Yes } \\
\hline Vatva B & No & Yes & $\begin{array}{l}\text { Mobile Health } \\
\text { Van }\end{array}$ & Yes & Yes & & \\
\hline $\begin{array}{l}\text { Bage- } \\
\text { firdos }\end{array}$ & $\begin{array}{l}\text { Under } \\
\text { process }\end{array}$ & Yes & No & Yes & Yes & No & No \\
\hline
\end{tabular}

Resettlement has a major impact on education (Tables 24 and 25). After dispossession, 18 percent of students dropped out of school; an additional 11 percent lost school attendance, with an average of 94 days lost. Households that relocated twice suffered the most. The increased distance to public schools, lack of adequate access to public transport, and needed funds and time for reconstruction and readjustment to the new site were cited by 80 percent of households as reasons for chronic or temporary loss of school attendance. Most students who resumed school faced longer travel at much higher expense.

Table 24: School dropout and loss of school days after displacement

\begin{tabular}{|l|l|l|l|}
\hline & $\begin{array}{l}\text { \% of } \\
\text { dropouts }\end{array}$ & $\begin{array}{l}\text { \% of students who } \\
\text { lost school days }\end{array}$ & $\begin{array}{l}\text { Average loss of } \\
\text { school days }\end{array}$ \\
\hline Interim Site & $33 \%$ & $9 \%$ & 74 \\
\hline BSUP site & $18 \%$ & $11 \%$ & 97 \\
\hline Interim (at first) & $31 \%$ & $19 \%$ & 288 \\
\hline BSUP (after interim) & $33 \%$ & $2 \%$ & 43 \\
\hline Demolished Site & $20 \%$ & $20 \%$ & 21 \\
\hline Overall & $\mathbf{1 8 \%}$ & $\mathbf{1 1 \%}$ & $\mathbf{9 4}$ \\
\hline
\end{tabular}


Table 25: Increase in distance to school and travel to school expenditure after

\begin{tabular}{|l|l|l|l|l|}
\hline & $\begin{array}{l}\text { Average } \\
\text { increase in } \\
\text { distance to } \\
\text { school } \mathbf{( K m})\end{array}$ & $\begin{array}{l}\text { \% increase } \\
\text { in distance } \\
\text { to school }\end{array}$ & $\begin{array}{l}\text { \% work trips } \\
\text { shifted to } \\
\text { private and } \\
\text { motorized mode } \\
\text { of transport }\end{array}$ & $\begin{array}{l}\text { \% increase } \\
\text { in travel } \\
\text { expenditure } \\
\text { to school }\end{array}$ \\
\hline $\begin{array}{l}\text { Interim } \\
\text { Site }\end{array}$ & 2.31 & $199 \%$ & $15 \%$ & $13 \%$ \\
\hline BSUP site & 1.78 & $235 \%$ & $20 \%$ & $107.3 \%$ \\
\hline $\begin{array}{l}\text { Interim (at } \\
\text { first) }\end{array}$ & 1.13 & $87 \%$ & $33 \%$ & $51.1 \%$ \\
\hline $\begin{array}{l}\text { BSUP } \\
\text { (after } \\
\text { interim) }\end{array}$ & -1.17 & $-48 \%$ & $-18.0 \%$ & $-78 \%$ \\
\hline Overall & $\mathbf{1 . 2 1}$ & $\mathbf{1 5 3 \%}$ & $\mathbf{1 5 \%}$ & $\mathbf{5 1 \%}$ \\
\hline
\end{tabular}

Access to health facilities is similarly poor. Although primary health centres were constructed on almost all occupied BSUP sites, only two were functional; at the other sites mobile health vans were operated by AMC (Table 23). At the interim site a weekly mobile health service was provided only in 2010 following civil society, media and judicial pressure. This is insufficient for a large population with significant health issues, nor do these mobile services respond to emergency needs. The four AMC multi-specialty hospitals are on average $5.7 \mathrm{~km}$ distant, and only three BSUP sites have a hospital closer than $6 \mathrm{~km}$ away (Table 26).

Table 26: Distance to municipal hospitals (in Km)

\begin{tabular}{|l|r|r|r|r|}
\hline Site & $\begin{array}{r}\text { Civil } \\
\text { Hospital }\end{array}$ & $\begin{array}{r}\text { VS } \\
\text { Hospital }\end{array}$ & $\begin{array}{r}\text { Sharda } \\
\text { Hospital }\end{array}$ & $\begin{array}{r}\text { LG } \\
\text { Hospital }\end{array}$ \\
\hline $\begin{array}{l}\text { BSUP Ajit } \\
\text { Mill }\end{array}$ & 4.74 & 7.24 & 3.15 & 4.96 \\
\hline $\begin{array}{l}\text { BSUP Bag- } \\
\text { e-Firdosh }\end{array}$ & 12.09 & 12.81 & 10.51 & 4.45 \\
\hline $\begin{array}{l}\text { BSUP } \\
\text { Isanpur }\end{array}$ & 8.83 & 9.56 & 6.65 & 1.95 \\
\hline $\begin{array}{l}\text { BSUP } \\
\text { Odhav }\end{array}$ & 11.22 & 14.65 & 9.68 & 10.69 \\
\hline $\begin{array}{l}\text { BSUP } \\
\text { Vadaj }\end{array}$ & 6.69 & 6.75 & 9.38 & 11.85 \\
\hline $\begin{array}{l}\text { BSUP } \\
\text { Vatva }\end{array}$ & 14.09 & 11.79 & 12.57 & 6.60 \\
\hline $\begin{array}{l}\text { Interim } \\
\text { site }\end{array}$ & 11.18 & 7.56 & 12.50 & 7.77 \\
\hline
\end{tabular}




\subsection{5 e. Health risks (morbidity and mortality, food insecurity)}

Health risks on resettlement sites are exacerbated by such factors as poor access to safe drinking water, sanitation and waste management, and fair price shops or below poverty line identity cards for subsidized food rations.

Policy: Claims of access to sanitation and waste disposal were perfunctory in the DPR appraisal checklist, which inquires whether provisioning for water supply, sewerage, solid waste disposal, storm water drains and street lighting has been made in the BSUP project(Government of India, 2009a). Claims related to issues of food security and provision of FPS were absent in BSUP guidelines.

Reality: The interim site is adjacent to AMC's solid waste disposal site and had negligible services. Contaminated tap water was supplied for two hours a day, community toilets were dysfunctional and solid waste was collected once a fortnight. On BSUP sites, although basic services were provided as per guidelines, the quality of services was compromised. The sewerage network was described as choked and overflowing, and households disposed of solid waste in open spaces, with AMC clearing the bins only once a week. These factors have led to poor hygiene and increased incidence of related diseases. The lack of clean drinking water on the interim site and many BSUP sites has contributed to ill health, and dysentery, typhoid fever, viral and bacterial gastroenteritis, and hepatitis were common in almost every house. A study of drinking water quality(Dave, June 21, 2012 )showed alarmingly high concentrations of chemicals and coliform bacteria (1600 parts per million (ppm) as against the prescribed limit of $2 \mathrm{ppm}$ ) and declared the water "unfit" for consumption. Several residents reported their experiences: "The water is so murky that we allow an hour for the sediments to settle before scooping it from the top", "The day after we shifted here, our daughter Roshni began vomiting. Within 24 hours, she was dead" or "What can be more basic than drinking water? Yet, if you store water in the house for two days, it starts stinking. We cannot afford to hire water tankers. We have been left here to die."

Food insecurity exacerbates health risks. Only 20 percent of displacees have been issued the identity cards that allow access to the fair price shops, which in any case are not available at the new localities. Others bought food at market prices. Unlike at the departure slums, no shopkeepers offered staple foods on credit. The loss of employment also means lowering essential food intake and can lead to undernourishment.

Stress from the general insecurity adds to the risks. According to one woman (Ahmedabad Mirror Bureau, 2011 ),"There is no electricity here. The area 
becomes dark at night and very unsafe for us, especially women and children... Women constantly fear being molested. "Even suicide has been reported.

\subsection{6 f. Marginalization}

The marginalization of those displaced is experienced in economic, social and psychological terms, and expressed through loss of human capital, loss of confidence and feelings of vulnerability. The coercive nature of the displacement and frequent hostility from host communities contributes further to what is often a pre-existing sense of exclusion.

Our study shows that vulnerable religious minority groups and oppressed castes were disproportionately represented amongst the displacees; 25 percent were Muslims, compared to 12 percent in the city, and a striking 88 percent belonged to scheduled castes, scheduled tribes or other backward classes.

Eviction without prior notice and subjugation of minority households have been reported. According to a newspaper report(DNA Agency, 2011), "...when they [slum dwellers] asked officials to show some mercy on at least the women and children, they behaved rudely with the women. The hutment [hut encampment] dwellers allege that one official struck a woman with a stick." James(2011) reports a displaced Muslim garage owner's plea, "All of a sudden the AMC bulldozers came and demolished our houses. I don't know what do to. I have been standing here searching for my belongings which are buried under the debris." On some BSUP sites located within relatively prosperous neighbourhoods, settlers were labelled "chapprawala" (a pejorative for one living under a tin roof or "slumdog"). At one site they were barricaded from entering the adjoining neighbourhood park.

\subsection{7 g. Social disarticulation}

Displacement fragments the social fabric of a community, including its spatial, temporal and cultural determinants(Cernea, 2000b, Downing, 1996). As kinship groups, voluntary associations and mutual help groups become scattered, the capacity for collective action or social capital is lost. The resulting alienation remains unperceived and unrecorded and has long-term consequences(Cernea, 2000b, Serageldin, 2006).

Policy: According to AMC, "on all BSUP sites Non-Government Organizations (NGOs) have been appointed for community mobilization and the formation process is ongoing." 39 The NGOs argued, however, that AMC's practice of fragmentary resettlement caused delays: "A Resident Welfare Association (RWA) can be formed by us only when all houses on a site are allotted to households and full community representation is realized. In the current scenario, 100 percent allotment of all houses is not witnessed on any BSUP 
site because of AMC's practice of ad hoc allotment. Consequently the formation is being inordinately deferred." 40

There was no policy attention to averting social disarticulation by planning for group relocation based on kin units, extended families, neighbourhoods and ethnic groups.

Reality: Our study shows that communities have been relocated in a dispersed manner over six BSUP sites rather than in social groups or units despite the possibility of the latter (Table 27). For instance, the Kagdivad community was resettled over four sites, each site at least $4 \mathrm{~km}$ distant from the others. After relocation, 44 percent of households applied for transfer to another site to be reunited with their former neighbours and kin, and many more were unhappy with the situation. About 17 percent of the allotted units remained unoccupied as families preferred to reside close to the departure slum site and their social networks.

On BSUP sites where communities have been resettled in fragments, social disarticulation was strikingly evident. In Vatva, where groups from nine slums were relocated, participation of households in the upkeep of common property resources and their interpersonal harmony was virtually absent. Most common spaces were covered with garbage, water pilferage from common tanks had become routine, and fights between neighbours over common property issues were frequent (Figure 20). Former slum leaders were unwilling to create structures for self-administration, citing lack of interest and identification with the new community. Residents expressed a sense of powerlessness and dependency on AMC intervention to prevent further decay of common property. ${ }^{41}$
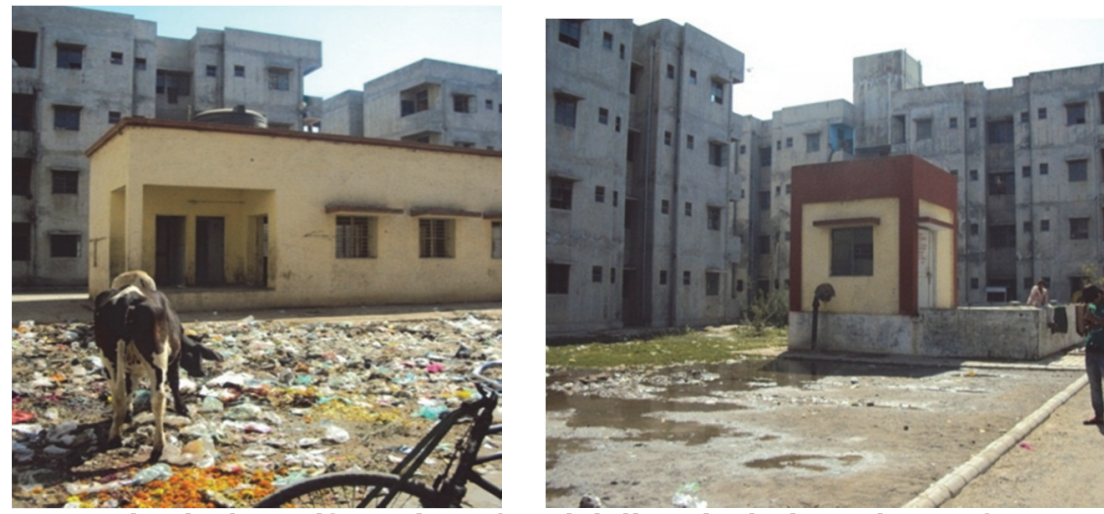

Figure 20: Physical manifestation of social disarticulation: abuse of common property and infrastructure on BSUP site at Vatva 
Table 27: Resettlement pattern of slum communities on various resettlement sites

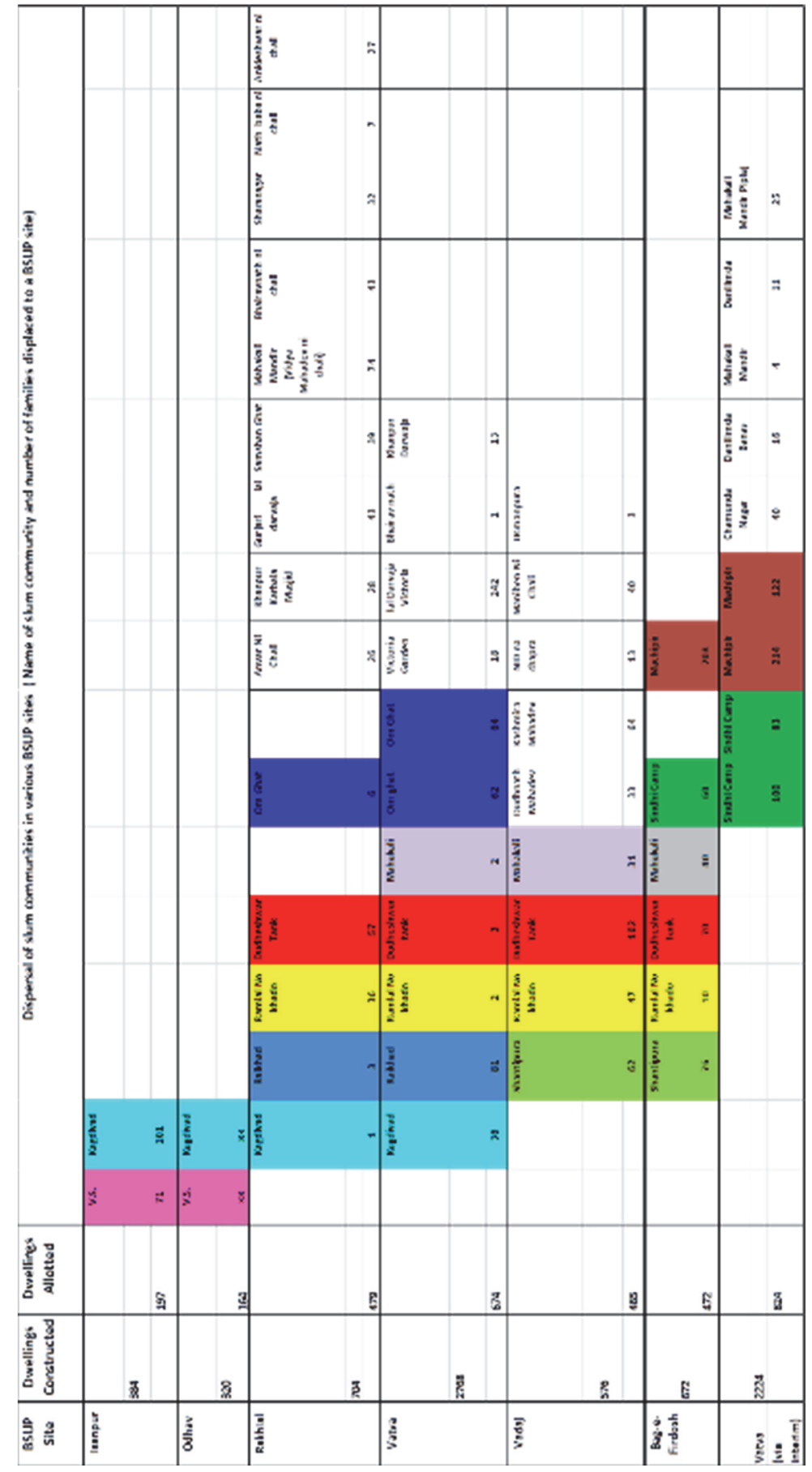




\subsection{8 h. Uncertainty (in the pre-dispossession processes)}

Uncertainty has emerged in our research as an additional form of impoverishment. As initially proposed by de Wet (2006) we suggest that exclusion from the planning of the resettlement processes and lack of transparent information leads to uncertainty in the community even prior to dispossession, enhances the perception of risk, distracts people from pursing their economic activities and contributes to impoverishment.

Policy: Under JNNURM guidelines, BSUP projects were to be preceded by City Development Plans identifying development priorities through stakeholder consultations. One objective was to gain consensus of the poor in project identification, prioritization, and willingness and ability to pay (Government of India, 2009c). An appraisal report on the Ahmedabad City Development Plan by the National Institute of Urban Affairs, however, points to uncertainty that the consultation process ever involved representatives of the poor. Slum leaders, activists and academics reiterated the exclusionary and tokenistic nature of these consultations. One activist explained that "Even slum leaders were bypassed in the consultation process. The result being that decisions like identification of project affected people, location of resettlement sites, dwelling unit size and cost, beneficiary contribution and affordability, and the relocation criteria, which were critical decisions for the affected slum dwellers were taken without a rigorous understanding of their needs, demands and affordability." 41 There is nothing in the BSUP guidelines on the subject of eviction notices and eligibility criteria, and states and local governments were allowed to define these. The consequences in Ahmedabad are discussed below.

Reality: Uncertainty within households about the outcome of displacement was evident prior to actual dispossession, from the unpredictable time between when AMC issued eviction notices and when resettlement was implemented (Table 28). Due to the limited information available, household heads, often the principal earners, spent time and resources consulting with community members, leaders and AMC and pursuing litigation in the High Court to prevent demolition. Our study shows that 29 percent of households joined such litigation after receiving an eviction notice. AMC practices exacerbated uncertainty. Some households were given both eviction and resettlement notices; others received only an eviction notice, leading to mistrust and division within communities. 
Table 28: Issue of Notice prior to demolition and resettlement

\begin{tabular}{|l|l|l|}
\hline Resettlement Site & \multicolumn{2}{l|}{$\begin{array}{l}\text { Notice for eviction prior to demolition } \\
\text { and resettlement }\end{array}$} \\
\hline & (Range in days) & (Average in days) \\
\hline Interim Site & 0 to 180 & 33 \\
\hline Permanent (BSUP) Site & 1 to 365 & 82 \\
\hline Interim (at first) & 0 to 180 & 74 \\
\hline BSUP(after interim) & 7 to 90 & 42 \\
\hline $\begin{array}{l}\text { No resettlement (On demolished } \\
\text { site) }\end{array}$ & 0 to 15 & 14 \\
\hline
\end{tabular}

Our study shows 40 percent of the sampled households were informed about "stakeholder consultations" but only 8 percent attended them, mostly because of inconvenient venues and times and additional travel costs. Our evidence suggests that limited dissemination of information and the design of the time and venue were intentional on the part of AMC to limit attendance at the consultations. At the very least, AMC has shown little regard for the opportunity costs of attending such consultations. Moreover, AMC practised discriminatory approaches to eligibility, for which households had to present prescribed documents, either survey identity cards issued in 2002 for the SRFD projectaffected people or identity cards issued by the slum listing from 1976 for others. Only 10 percent of surveyed households possessed one of these documents, more in the case of SRFD than others. Desai describes such discriminatory practices as "flexible governing", aimed to constrain community mobilization and opposition (2012b). These practices could also in part be attributed to a deficit of BSUP units relative to the number of households to be displaced - as few as one to every five households in need, depending on the estimate of those to be displaced. This exacerbated people's perception of risk and uncertainty.

\subsection{Discussion}

Our research shows that all the forms of impoverishment proposed by Cernea have emerged, in varying degrees, in all the four categories of displaced households in Ahmedabad. Many households have also experienced very high levels of "uncertainty", which we propose should be seen as an additional form of impoverishment, and recognized in risk mitigation plans through promotion of high levels of community participation throughout the entire resettlement process.

Our findings clearly indicate that relocation distance is the most significant cause of post-displacement impoverishment and must be adequately addressed in rehabilitation policy. Most of the impoverishment found amongst Ahmedabad's displaced populations (i.e. joblessness, lack of access to community facilities, health risks and social disarticulation) derive from displacement distance along with other factors. Similar research on Indore 
(Patel and Mandhyan, 2014) has demonstrated that those resettled on-site were substantially less impoverished than those resettled off-site. Despite a large body of evidence on the impoverishment of displacees, there was little in BSUP policy that specifically acknowledged or targeted the various components of impoverishment. For instance, BSUP policy included only token reference to such impoverishment risks as landlessness or relocation distance, joblessness, homelessness, loss of access to community facilities, health risks and social disarticulation; and food security and social marginalization were completely ignored. In some instances where there was relevant policy, the realities of implementation did not match the rhetoric. This evident gap between the rhetoric and practice of local government has led to impoverishment risks becoming a reality. As impoverishment increases on the inhospitable and distant resettlement sites, where people live in abject poverty (Menon-Sen and Bhan, 2008), the displaced defect and return to the old slums or vicinities (Dupont, 2008), leading to low occupancy levels on BSUP sites across Indian cities and to higher densities in the vicinity of old slum sites (Mahadevia et al., 2013). In Ahmedabad also, during the time of our field visit in May 2011 we found only 35 per cent occupancy of BSUP units constructed, with most of them still unallotted; of those units that had actually been allotted, 83 per cent were occupied.

The failure of resettlement is usually attributed to dysfunctional communication between decision-makers and affected communities and the consequent lack of understanding of the latter's needs and aspirations, leading to the further impoverishment of displacees. There are clear signs that this is also true for Ahmedabad. Emphasizing the need for community participation, Patel et al. (2013) have shown how community participation and empowerment in critical decision-making underpins a successful resettlement process. Many of the BSUP program's inadequacies and failures in Ahmedabad are undoubtedly at least partly attributable to the exclusions of the affected communities from all aspects of planning and implementation.

\subsection{Conclusion}

Development-induced displacements and resettlements in the rapidly developing cities of the South are an important socio-political issue. In India, evidence of large-scale displacements of the urban poor in all major cities is emerging, spurred by gentrification and infrastructure projects to create worldclass cities. It is critical to focus more attention on research on urban DIDR and its consequences for the urban poor and to search and advocate for more sensitive approaches and mitigation policy measures. Our analysis of DIDR in Ahmedabad has clearly indicated that the current practices of local government have led to impoverishment amongst the dispossessed and the displaced. In the absence of appropriate guidelines, the urban poor are virtually excluded from the design, planning, implementation and management of resettlement 
processes under BSUP. Although BSUP has come to a close it has paved the way for RAY. Ideally, the lessons learnt from BSUP should contribute to better conceptualization of RAY to avoid, for example, an over-emphasis on off-site resettlement options rather than in-situ upgrading, or the adoption of exclusionary practices, all of which lead to impoverishment of the so-called beneficiaries. The price of not building on these lessons will be high, especially for those targeted by DIDR projects and for public funds spent on such subsidized rehabilitation housing programs. 
Chapter 6

Synthesis 


\subsection{Introduction}

My study is the only exploratory and empirically grounded research to-date to critically reflect on implications of tensions between decentralisation and neoliberalisation on rights of citizens and the socio-spatial order in Indian cities. However, before I go further, I would like to discuss a poignant event on Ahmedabad's riverfront reported in global media which highlights the significance of Sabarmati Riverfront Development (SRFD) project and the kind of urbanism Ahmedabad and Gujarat represent for India (Figure 21).

Figure 21 : A poignant event in the Sabarmati riverfront

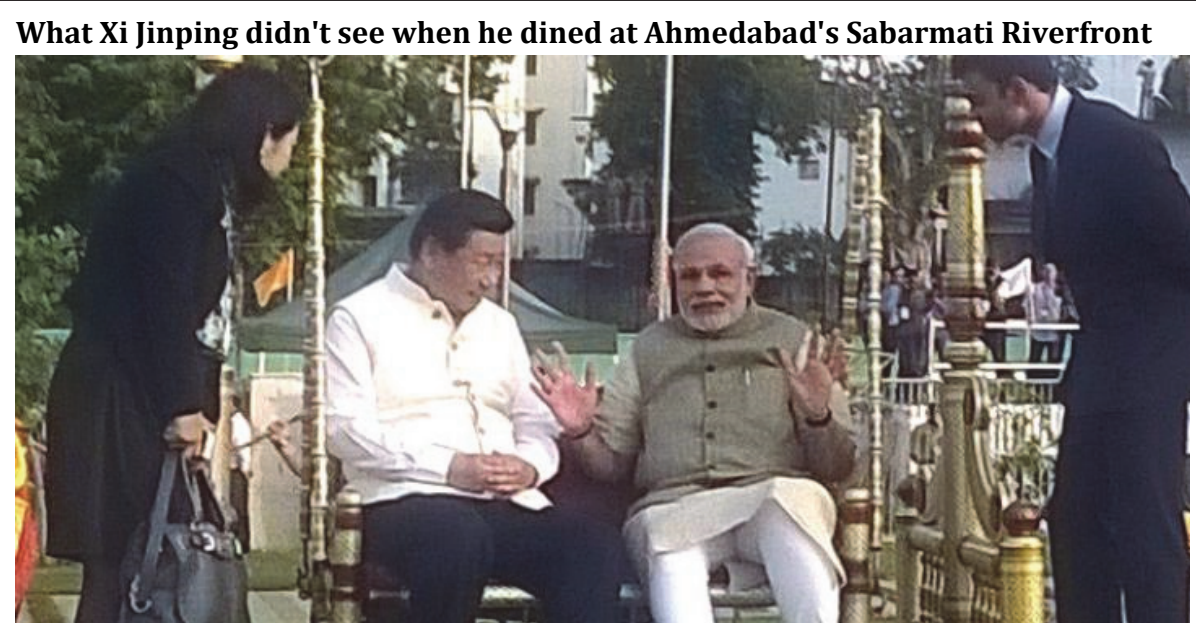

The Chinese president dining with Prime Minister Narendra Modi luxuriously at Ahmedabad's star symbol of development, but the slum-dwellers displaced by the project are still fighting for justice (Source: Scroll.in, September 17, 2014)

Inaugurated in 2012, Sabarmati Riverfront development project was Narendra Modi's pet project as the Chief Minister of Gujarat. Now, as the Prime Minister of India he is using the riverfront with its $10 \mathrm{~km}$ promenade, green lawns, speed boats and shimmering lights to lure Chinese investments for Indian infrastructure development. The message that Modi wants to send is clear: India is just as capable as China or any western country of building 'world-class' cities with grand signatures of their upward mobility. The Sabarmati Riverfront also has the dubious distinction of displacing large numbers of slum dwellers but $X i$ is likely to be impressed by the spectacle anyway as China has followed a similar model of displacement to rebuild its own cities. The Riverfront project, involved clearing out the urban poor to create facilities that typically benefit only middle and upper class citizens. The main difference perhaps is that the poor in China are not allowed to fight for their rights in court, while many of the riverside slum dwellers in Ahmedabad are fighting for justice in the Gujarat High Court. 
The urban development of Ahmedabad has become a role model for India as the "çity brand" has gradually gained prominence in the last decade and awards have been pouring in for many of its neoliberal projects and governance model (Table 29). It owes its current central position in the national and global stage to Prime Minister Narendra Modi, the former Chief Minister of Gujarat and chief architect of these projects.

Table 29: Awards for urban development projects for AMC (2002-2012)

\begin{tabular}{|c|c|c|c|}
\hline Year & Award title & Award by & Purpose \\
\hline 2003 & $\begin{array}{l}\text { CRISIL National Award } \\
2003\end{array}$ & $\begin{array}{l}\text { Credit Rating Information } \\
\text { Services of India }\end{array}$ & $\begin{array}{l}\text { Best Financial Management } \\
\text { System }\end{array}$ \\
\hline 2004 & $\begin{array}{l}\text { International Best } \\
\text { Practices } 2004\end{array}$ & $\begin{array}{l}\text { International City/Country } \\
\text { Management Association } \\
\text { (ICMA) Washington D.C }\end{array}$ & $\begin{array}{l}\text { Best Practices in City Civic } \\
\text { Centers \& e-Governance }\end{array}$ \\
\hline 2006 & $\begin{array}{l}\text { UNHABITAT Dubai } \\
\text { International Awards }\end{array}$ & UN HABITAT & $\begin{array}{l}\text { Best Practices to Improve the } \\
\text { Urban Environment (Slum } \\
\text { Networking Project) }\end{array}$ \\
\hline 2008 & $\begin{array}{l}\text { India Tech Excellence } \\
\text { Awards }\end{array}$ & India Tech Foundation & $\begin{array}{l}\text { Main Streaming Urban Poor } \\
\text { Slum Networking to improve } \\
\text { habitat Of Urban } \\
\text { Poor \& providing livelihood } \\
\text { opportunities }\end{array}$ \\
\hline 2008 & $\begin{array}{l}\text { Horizontal Transfer of ICT- } \\
\text { based } \\
\text { Best Practice GOLD Awards }\end{array}$ & Government of India & Best Practise in e-Governance \\
\hline 2009 & $\begin{array}{l}\text { Best Mass Transit } \\
\text { System }\end{array}$ & Government of India & $\begin{array}{l}\text { Janmarg - Ahmedabad } \\
\text { BRTS Project }\end{array}$ \\
\hline 2010 & $\begin{array}{l}\text { International Awards on } \\
\text { Sustainable Transport }\end{array}$ & TRB at Washington DC USA & $\begin{array}{l}\text { Janmarg - Ahmedabad BRTS } \\
\text { Project }\end{array}$ \\
\hline 2010 & $\begin{array}{l}\text { National Award for } \\
\text { Innovations in } \\
\text { servicing the needs of the } \\
\text { Urban Poor }\end{array}$ & $\begin{array}{l}\text { GoI, India Urban Space } \\
\text { Foundation, Swedish } \\
\text { International Development } \\
\text { Agency (SIDA) \& World } \\
\text { Bank }\end{array}$ & $\begin{array}{l}\text { Basic Services for the Urban } \\
\text { Poor - BSUP (JNNURM) }\end{array}$ \\
\hline 2010 & $\begin{array}{l}\text { International Award of } \\
\text { Outstanding } \\
\text { Innovation in Public } \\
\text { Transport }\end{array}$ & $\begin{array}{l}\text { International Transport Forum } \\
\text { (ITF) and } \\
\text { International Association for } \\
\text { Public Transport (UITP) }\end{array}$ & $\begin{array}{l}\text { Janmarg - Ahmedabad BRTS } \\
\text { Project }\end{array}$ \\
\hline 2010 & $\begin{array}{l}\text { Knowledge and Research } \\
\text { Award }\end{array}$ & 59th UITP World Congress & $\begin{array}{l}\text { Janmarg - Ahmedabad BRTS } \\
\text { Project }\end{array}$ \\
\hline 2010 & Daring Ambition Award & 59th UITP World Congress & $\begin{array}{l}\text { Janmarg - Ahmedabad BRTS } \\
\text { Project }\end{array}$ \\
\hline 2010 & $\begin{array}{l}\text { Initiatives for Social } \\
\text { Housing }\end{array}$ & $\begin{array}{l}\text { 41st ANNIVERSARY OF } \\
\text { HUDCO }\end{array}$ & BSUP \\
\hline 2011 & AIILSG Nagar Ratna Award & President of India & Best Performing City \\
\hline 2012 & $\begin{array}{l}\text { Best Practices to Improve } \\
\text { the Living Environment }\end{array}$ & $\begin{array}{l}\text { Housing and Urban } \\
\text { Development } \\
\text { Corporation (HUDCO) }\end{array}$ & $\begin{array}{l}\text { Kankaria Lake Front } \\
\text { Development, }\end{array}$ \\
\hline
\end{tabular}

Source: Mahadevia 2014 
This research is highly relevant for India at this juncture. For other metropolitan cities, emulating the "successful" riverfront and lakefront development and BRTS projects of Ahmedabad, as well as for award "agencies", including multilateral and bilateral institutions like the World Bank, SIDA and ICMA, it provides a counter perspective to the images of successful and modern urban development. Before synthesising the published papers and discussing possible implications for urban governance in India, I recapitulate the key aspects of my research journey.

The riverfront and lakefront projects have indeed given a civic space to the middle class citizenry and evoked among them a sense of pride and belonging. I have personally facilitated visits of friends, families and professional colleagues to these projects, initially with pride and later, as time elapsed and I learned from local media about the eviction of slum dwellers in the riverfront, with guilt (of being part of the predatory middle class). Through my field work I was confronted with a side of the city and its governance that I had trouble coming to terms with as a citizen. I felt that the prestigious projects somehow subverted the inclusive Gandhian society once typified by Ahmedabad; a society which took care of its disadvantaged citizens. As I delved into the empirical context and the literature, I started grasping the missing links which needed to be addressed. Such personal dilemmas and self-reckoning continue to this date as I move towards closure of the research journey. As an urban planning academic and practitioner, I have matured epistemologically from positivism to interpretivism and empirically grounded research which have allowed me a much richer understanding of the social reality than a positivist, hypothesis-testing approach.

In the remainder of this chapter I will draw together the findings and lessons entailed within the three empirical papers that were discussed in chapters 3 to 5 above. In the sections ahead, I synthesise the research sub-questions and the main question. The response to the main question is the starting point for a subsequent examination (chapter 7) on whether and how information transparency can catalyse participation of citizens and enable them to negotiate socio-economic rights.

\subsection{Synthesis}

The findings in chapters 3 to 5 consist of rather detailed discussions within the conceptual frameworks of each paper. Here, I summarise the answers to the research questions and show how the conceptual framework I began with (Figure 9 in section 2.3) became progressively enriched and refined by successive empirical findings. The neoliberal shifts in Ahmedabad, discussed in section 1.3.4, which influenced shifts in the conceptual framework, are summarised in Figure 22. A distinction is made between ideological shifts and 
how they result in observable, tangible shifts in aspects of urban governance and policy. These serve as a legend for further discussions in this chapter.

\section{Neoliberal shifts \\ Ideological shits}

Sa: Market logic of efficiency, democratic deliberation is inefficient

$\mathrm{Sb}$ : Middle class is more favoured and influential electorate

Tangible shifts

S1: Market logic of 'self financing' and commodification of basic services

S2: Outsourcing some services to private companies

S3: Outsourcing projects to semi-autonomous bodies for efficient delivery

S4: Beautification and infrastructure upgrade projects to 'improve image' and attract new businesses

S5: Commodification of commons and reserves for poor for profitable uses

Figure 22 : Summary of neoliberal shifts in Ahmedabad

I proceed to synthesising successive research questions (and papers), each followed by a brief intermezzo, the purpose of which is to highlight the relations between publications and overlaps and to explain new development in empirical settings.

\subsubsection{Sub-question 1}

\section{Sub-question 1: How are (un)propertied citizens affected by} decentralisation initiatives?

- How are participatory spaces created locally under the mandates of national and state governments?

- What opportunities do participatory spaces offer to the two social groups to deliberate on ward planning and budgeting processes and to negotiate their rights?

- How do the two social groups attempt to negotiate their rights and whose interests are best served?

- Is there a neoliberal bias in the decentralisation process in Ahmedabad?

To answer the first research question I focus on the part of the conceptual framework of the thesis (Figure 9 in section 2.3) that is shown in solid lines in Figure 23. This is an adaptation of Gaventa's (2006) framework of participatory spaces and their dynamic inter-relations that ideally leads to empowerment of all citizens and social order. The research findings show that "invited" spaces such as Ward Committees (WCs) and Area Sabhas (ASs) mandated by law, where citizens can deliberate and negotiate with government, have in reality become "closed" spaces to the detriment of unpropertied citizens. In following sections I elaborate on the findings. 
First, as the mandates to create participatory spaces are translated from higher (national-level) to lower (State-level) tiers of government they become progressively weakened and reduced. The weakening (or reduction) includes reduced proximity between citizens and the spaces, absence of citizen participation in WCs and differentiated participation in ASs that excludes the poor, absence of selection criteria for citizen membership in ASs, devolution of limited functions and powers to and no financial autonomy of WCs and ASs. While the State's mandates are weak, the practice of the Ahmedabad Municipal Corporation (AMC) is even weaker. ASs are not formed in any ward while WCs are formed but function as closed spaces, and are thus meaningless for the poor. This is because of the reluctance of the State and local government to share power with citizens in participatory spaces, which are deemed inefficient for "fast-track development" as suggested by Hay \& Jessop (1995). As a result neither the propertied nor the unpropertied citizens get the opportunity to deliberate in ward level planning and to be "shapers and makers" as termed by Cornwall and Gaventa (2001).

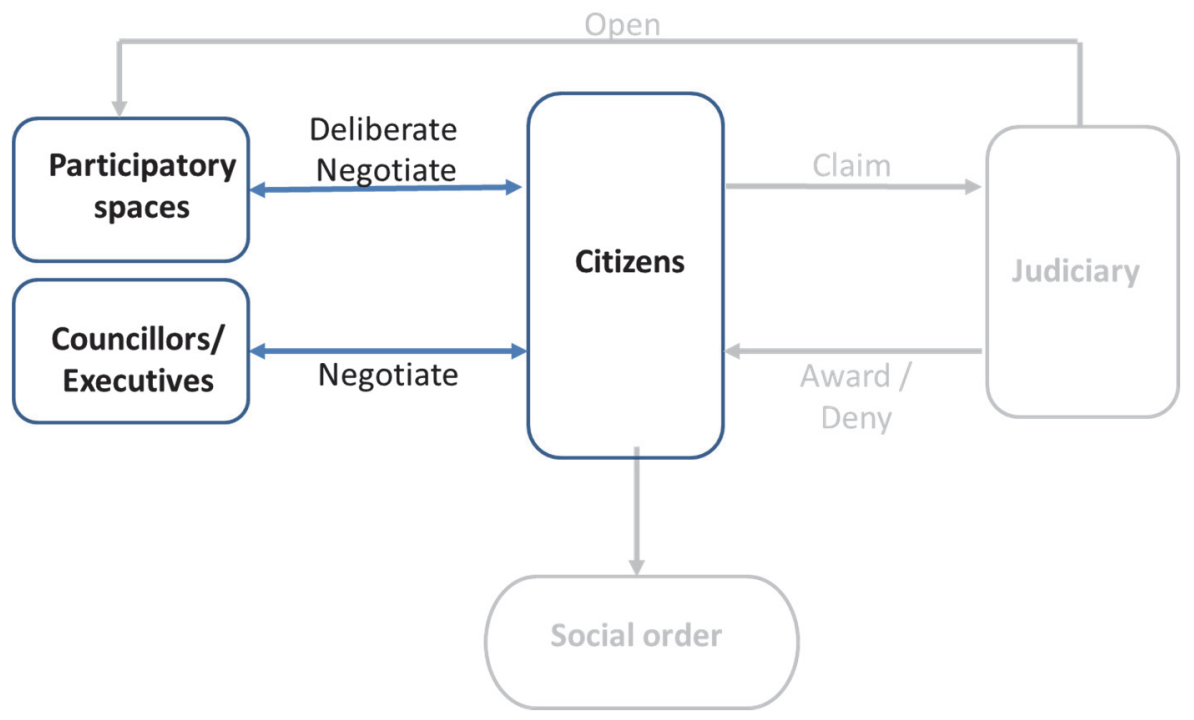

Figure 23: Research sub-question 1 - Conceptual framework

Second, the absence of invited spaces is to the detriment only of the unpropertied citizens. Propertied citizens successfully use the executive wing of city administration as well as e-governance and $\mathrm{m}$-governance platforms to negotiate their needs. Unpropertied citizens, who lack access to these platforms, rely on elected representatives (councillors) but with limited success. Unlike in other cities of India, where the poor successfully negotiate their needs with elected representatives through clientelism, in Ahmedabad this platform is also captured by the elite middle class, which has emerged as a larger, more influential and favoured electorate in neoliberal Ahmedabad, as 
has been suggested by scholars (Swyngedouw, 2005, Crook and Sverrisson, 2003a).

Third, the poor mobilise to claim spaces of negotiation through judicial recourse from time to time, in response to closure of both invited and negotiating spaces, to negotiate their socio-economic rights. However, claimed spaces are one-off and have shown mixed results as they reclose upon the end of the judicial process rather than becoming permanent invited spaces for participation as proposed by Gaventa (2006).

To sum, I identify all three types of participatory spaces proposed by Gaventa (2006) but fail to find empirical evidence of the dynamic interrelationship between them that he suggests. The inclusiveness and empowerment in decentralisation rhetoric is not realized in local practice because of two neoliberal ideological shifts: democratic deliberation is inefficient and the middle class is a more desirable electorate. The latter has led to inequalities between the two social groups in terms of their success in negotiating socioeconomic rights. The initial conceptual framework (Figure 23), is now refined by empirical findings, as shown in Figure 24.

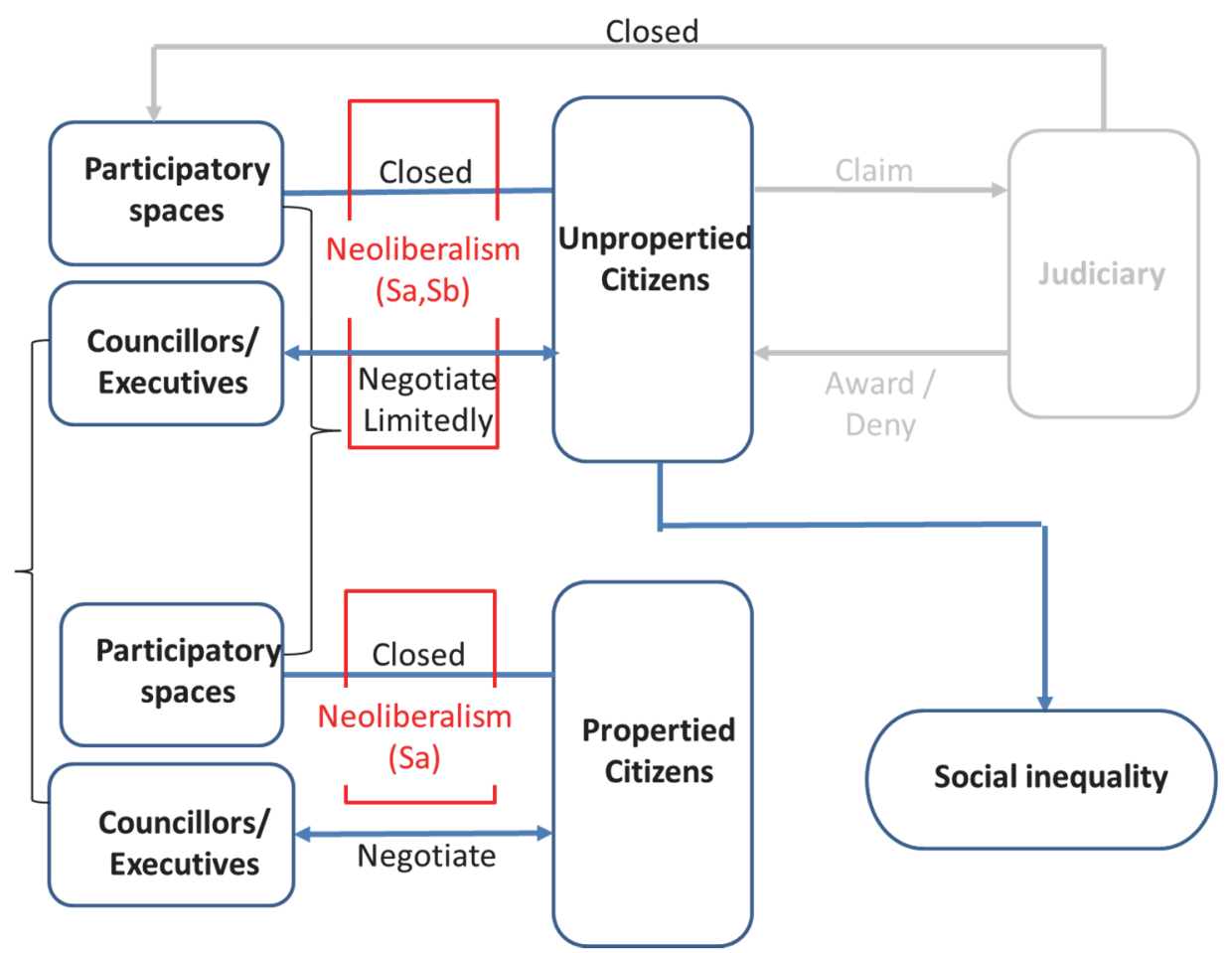

Figure 24 : Modified framework based upon findings for sub-question 1 
Intermezzo: Before answering the second research question some remarks are in order. During fieldwork for this research, three major claim making processes for various socio-economic rights were initiated by different slum communities in the Gujarat High Court in addition to many others which just petitioned for a "stay" order on impending evictions. Simultaneous claim making processes by aggrieved slum communities are common in Indian courts. I have alluded to research by fellow researchers on one of the three claim making process in section 3.3.2.3 concerning a claim in the Gujarat High Court, initiated by a pan city network of slum communities evicted by Sabarmati riverfront project, Sabarmati Nagarik Adhikar Manch (SNAM). They were claiming recognition of the right to shelter in general and to compensatory shelter on sites close to the current residences of evictees and to all households as per their enumeration survey. I have briefly discussed the outcome of this claim to establish that the claimed space by SNAM has not resulted in opening the closed participatory spaces.

I decided to focus on the other two claims for the second research question. These claims were initiated by two different slum communities, one seeking the right to basic services and the other seeking the right to shelter and revision of cut-off date (from 1976 to 1995) for compensatory shelter in case of unavoidable eviction. I used the claim making process as a backdrop to explore the stance of local government on rights of unpropertied citizens through the reply affidavits filed in the Court. Cut-off date revision falls in the purview of the local and State government and both were made respondents in the petition. This helped to explore the stance of the State government too.

\subsubsection{Sub-question 2}

\section{How does neoliberalisation affect key socio-economic rights of} unpropertied citizens and the social order of the city?

- How do the poor attempt to negotiate their right to basic services and to shelter (incl. the cut-off date), in the absence of "invited" spaces?

- How does the judiciary respond to their claim making?

- How does local (and State) government respond to the judicial process?

- What is the judiciary's and local government's response to the rights of the unpropertied citizens and to "closed" spaces?

I analysed the constitutionality upon which the petitions were filed, the response of the State and local governments through affidavits, the interpretation of the constitutionality by the judiciary in its final order and the State and local governments' response to the judicial order. The empirical findings of first research question sets the conceptual framework for the second as this is viewed as continuum of process of negotiation of socio-economic rights by citizens and I focus on the part of the conceptual framework that is shown in solid lines (Figure 25). My findings show that the right to basic 
services is commodified as a high-priced commodity, and the right to shelter is denied and compensatory shelter remains limited to the cut-off date of 1976 . Consequently, the terms of citizenship are discursively reconstituted on a property basis and the claimed spaces do not form open participatory spaces upon closure of judicial process. I attribute this to the neoliberal bias of the local and State government and the judiciary. In following section, I elaborate on findings in more detail.

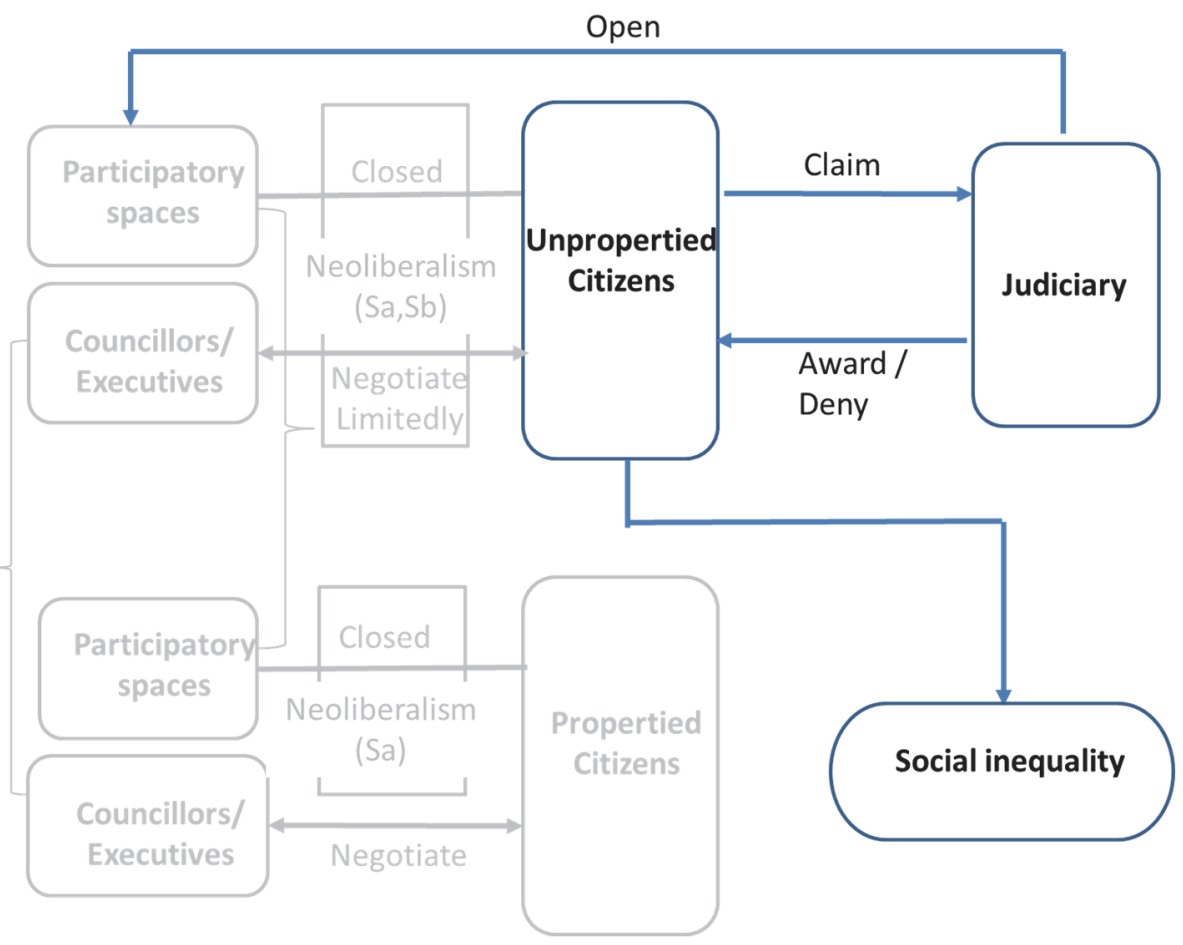

Figure 25: Research sub-question 2 - Conceptual framework

First, the judiciary perpetuates the State and local governments' neoliberal stance towards socio-economic rights of slum dwellers, but not as blatantly as other high courts and the Supreme Court of India. The Gujarat State High Court assumes a "duplicitous" stance of "stealthy sympathy" with the government and of "not blatant apathy" towards the poor. By assuming a "duplicitous" stance, it allows the poor to win small battles by temporarily halting evictions or ordering conditional access to basic services but paves the way for the government to win the war by actively disregarding the rightsbased discourse of the poor, which could potentially hinder the development of the neoliberal projects.

Second, the right to basic services is commodified as a high cost commodity as has also been suggested by others (Ong, 2006, Bhan, 2009, Rose, 1999). 
The judiciary affirmed the right but also allowed AMC the leeway of 'rules, regulation...' in agreeing or disagreeing to provide basic services to the poor. AMC acquiesced by formulating a program to provide basic services to poor, but with harsh conditions. Provision would not imply legal ownership of the land they had "encroached", water and sewerage connections would be provided only if the network and adequate quantity of water were available in that area, and basic services would come at a high price. Because of the neoliberal shift to "self-financing" and "cutting losses" of basic services, the right is reduced to a commodity and slum dwellers are reduced to consumers of that commodity, rather than treated as citizens with a right to public goods (Figure 26). Such harsh conditions and high fees for NOC are not imposed on a formal property owner applying for access to basic services. Thus discrimination on access conditions between the propertied and the unpropertied citizens was established.

Third, the right to shelter is rejected as a fundamental right and compensatory shelter is limited to a meagre few who can prove residence prior to the cut-off date of 1976. AMC denied the right on the grounds that "encroachers have no fundamental rights", and are an "obstruction to progress and development of the city", by means of beautification and infrastructure projects. AMC's rationale for restoring the 1976 cut-off date was "public interest" on the grounds that shifting the cut-off date to 1995 would mean recognising right to compensatory shelter of more slum dwellers and thus "obstructing development of city", "causing liability of large land parcel (for providing compensatory shelter) and heavy financial burden on AMC" thus "hampering handing over developed land to private owners" and result in "encouraging encroachers", "increasing encroachments" and "(removal of encroachments would) giving rise to legal complications". "Removal" of "encroachments" is implied as an expected and inevitable event.

Fourth, the social order of the city is altered by discursive framing of unpropertied citizens as against "public" interest and thus "othered" from the propertied "public" whose interest has to be protected. The terms of citizenship is discursively redefined in the affidavit which views unpropertied citizens as sub-grade having less rights than the propertied. The research confirms scholars (Appadurai and Holston, 1996, Bhan, 2009) conception that social inequality is naturalized as an inevitable part of neoliberal governance with propertied citizens becoming more equal than unpropertied, with more rights than the latter.

Fifth, rather than being an arbiter of justice, the judiciary allows such a framing of socio-economic right of the poor and differentiated terms of citizenship, thus sharing neoliberal bias of the government. 


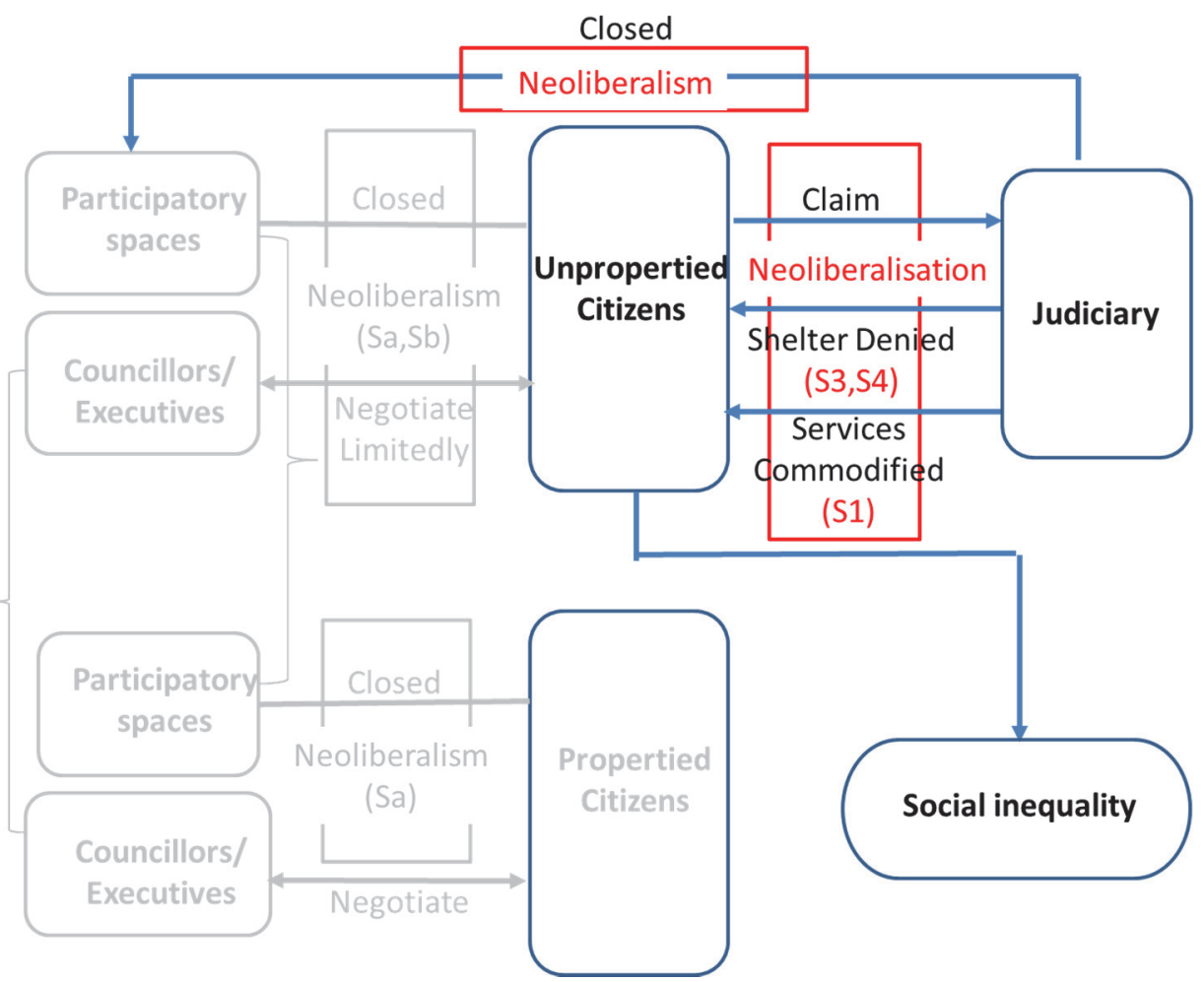

Figure 26: Research sub-question 2 empirical findings

To sum up, the long drawn claim making process (spanning over five and eight years in the petitions for shelter and basic services, respectively) does not lead to the "ordering" of institutionalisation of a permanent "invited" space for the unpropertied by the judiciary. On the contrary, Ward committees continue as "closed" spaces and Area Sabhas only exist on paper. When judicial process ends the negotiations between citizens and governments also end. The State (in policy) and local government (in practice) continue to resist "invited" spaces as they deem democratic deliberation to be inefficient and an obstacle to "fast-track development". The conceptual framework is further informed by these empirical findings as shown in Figure 26 which is to be read in conjunction with the legend for neoliberal shifts shown in Figure 22.

Intermezzo: Before answering the third research question two remarks are in order. First, the research undertaken for the second question revealed that a differentiated social order based upon property ownership also manifested on the spatial order of the city. Though this aspect has been discussed in the chapter 4, in synthesis it is discussed in answer to the third research question. 
Second, towards the end of fieldwork the Development Plan of Ahmedabad, 2021 was declared. Metro Rail Transit System (MRTS) emerged as a new modernization project aimed at "improving" the city's image. A Transit Oriented Development Zone (TOD) with a width varying from $250 \mathrm{mt}$ to 500 $\mathrm{mt}$ on either side of the MRTS and the BRTS networks was defined in the Development Plan. TOD implies higher a Floor Space Index (FSI) and higher market values for the properties falling in the zone. It also means removal of slums within the zone, either through market forces or through forced evictions. The consequences of such relocations was the subject of subquestion 3 .

\subsubsection{Sub-question 3}

Sub-question 3: How is the socio-spatial order of the city influenced by neoliberalisation and what are the consequences for the evicted slum dwellers?

- How does neoliberalisation alter the city's socio-spatial order: are shelter rights denied and is capital accumulation and dispossession evident?

- What are the consequences of eviction for the well-being of the dispossessed slum dwellers?

- How were the risks of their impoverishment addressed in the resettlement policy?

- How was community participation in critical decisions related to eviction and resettlement addressed?

The research findings show that social-spatial polarization is caused by neoliberal projects aiming at capital accumulation on one hand (for the propertied citizens and local governing institutions) and at the dispossession of slum dwellers on the other. The slum dwellers resettled on sites in the city's periphery are further impoverished. All forms of impoverishment proposed by Cernea (2000b) are found amongst displaces in Ahmedabad, partly because of weak policy for resettlement and weaker practice by AMC. A new form of impoverishment emerged, due to lack of information to the slum community regarding the eviction and resettlement process. The empirical findings of previous questions set the conceptual framework for the third question as this is viewed as continuum of (in)ability to negotiate socio-economic rights for the unpropertied and consequent social polarization manifesting itself on spatial order of the city (Figure 27 ). 


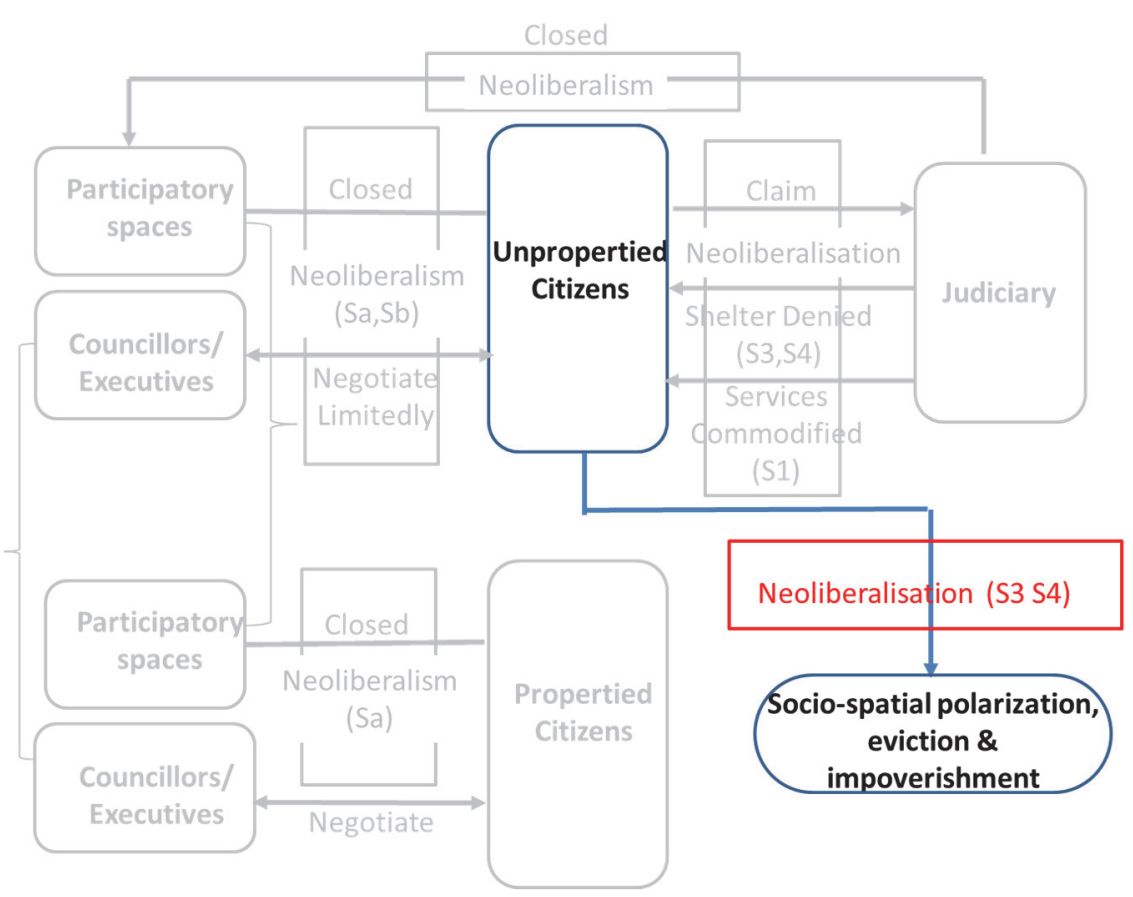

Figure 27: Research sub-question 3 - Conceptual framework and findings

First, differentiated rights lead to socio-spatial polarization when beautification and infrastructure projects such as riverfront and lake front development and BRTS and MRTS, aimed at improving the city's image, attracting global investments and boosting quality of life for the propertied middle class are implemented on one hand, whereas the land for such projects is expropriated from unpropertied citizens living in the core city area (Figure 28 and 29) with compensatory shelter offered to a meagre few who could prove residence in the slum prior to 1976 (December 2002 in case of SRFD) on sites in the periphery of the city (Figure 30). Socio-spatial polarisation is deepened because the degree of disenfranchisement among the unpropertied due to variations in cut-off date criteria. My research shows that about 46 per cent of the slum population (based on a 2010 survey) is in various stages of displacement by such projects while only 20 per cent of the potential displacees are actually eligible for compensatory shelter. The economic losses to potential displacee families will therefore be very high as about 91per cent reside in permanent well-built dwellings, with 68 per cent having own tap and 87per cent having own toilet, largely accessed as a high priced commodity. The risk of multiple forms of social impoverishment is almost inevitable. 


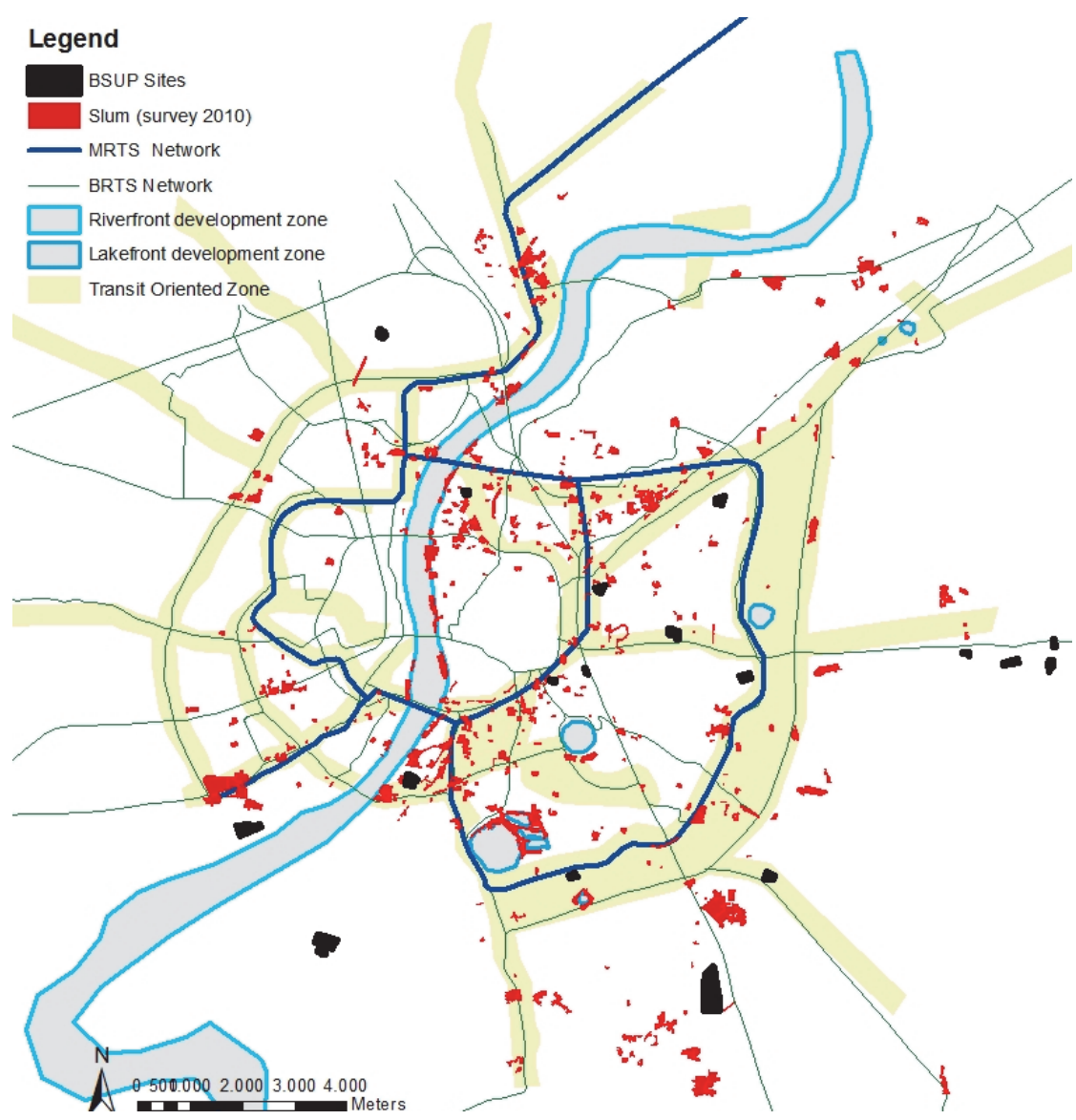

Figure 28: Locations of slums (2010 survey) and displacement inducing projects (MRTS, BRTS, TOD, Riverfront and lakefront development)

Source: Compiled by author from sources (AMC, NGOs and Primary surveys from 2010 to 2014 ) 


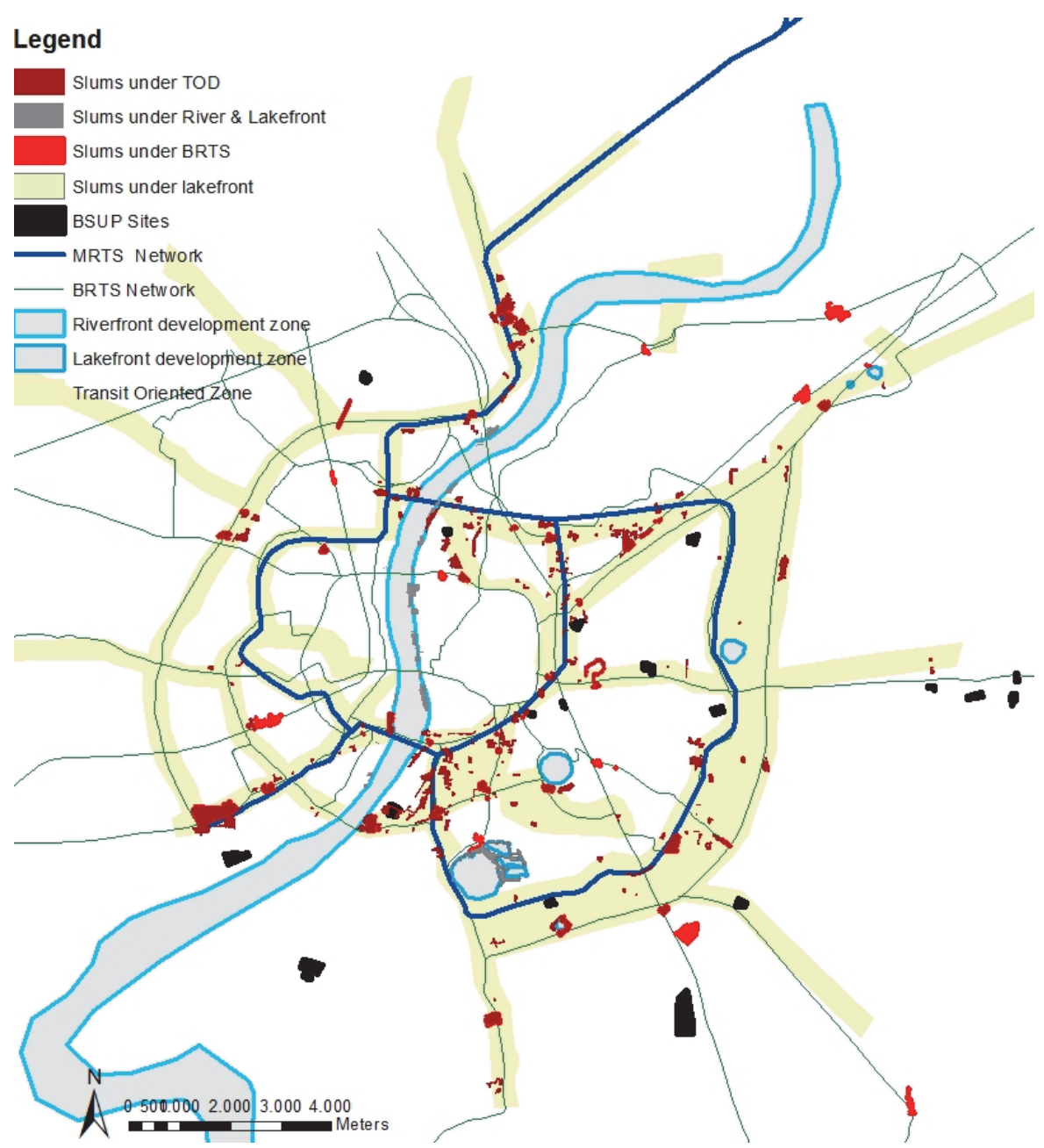

Figure 29: Slums to be displaced by projects (MRTS, BRTS, TOD, Riverfront and lakefront development)

Source: Compiled by author from sources (AMC, NGOs, Primary surveys from 2010 to 2014)

Second, Harvey's (2003) notion of "accumulation through dispossession" is observed in the riverfront and lakefront projects and in the TOD zone along BRTS and MRTS routes and in the core of the city. These are visualized as commercial corridors and opportunities to accumulate capital in the form of profit, rent and interest for the property owners and local government on one hand, but further impoverishment of the dispossessed slum dwellers resettled in the periphery of the city on the other hand. 


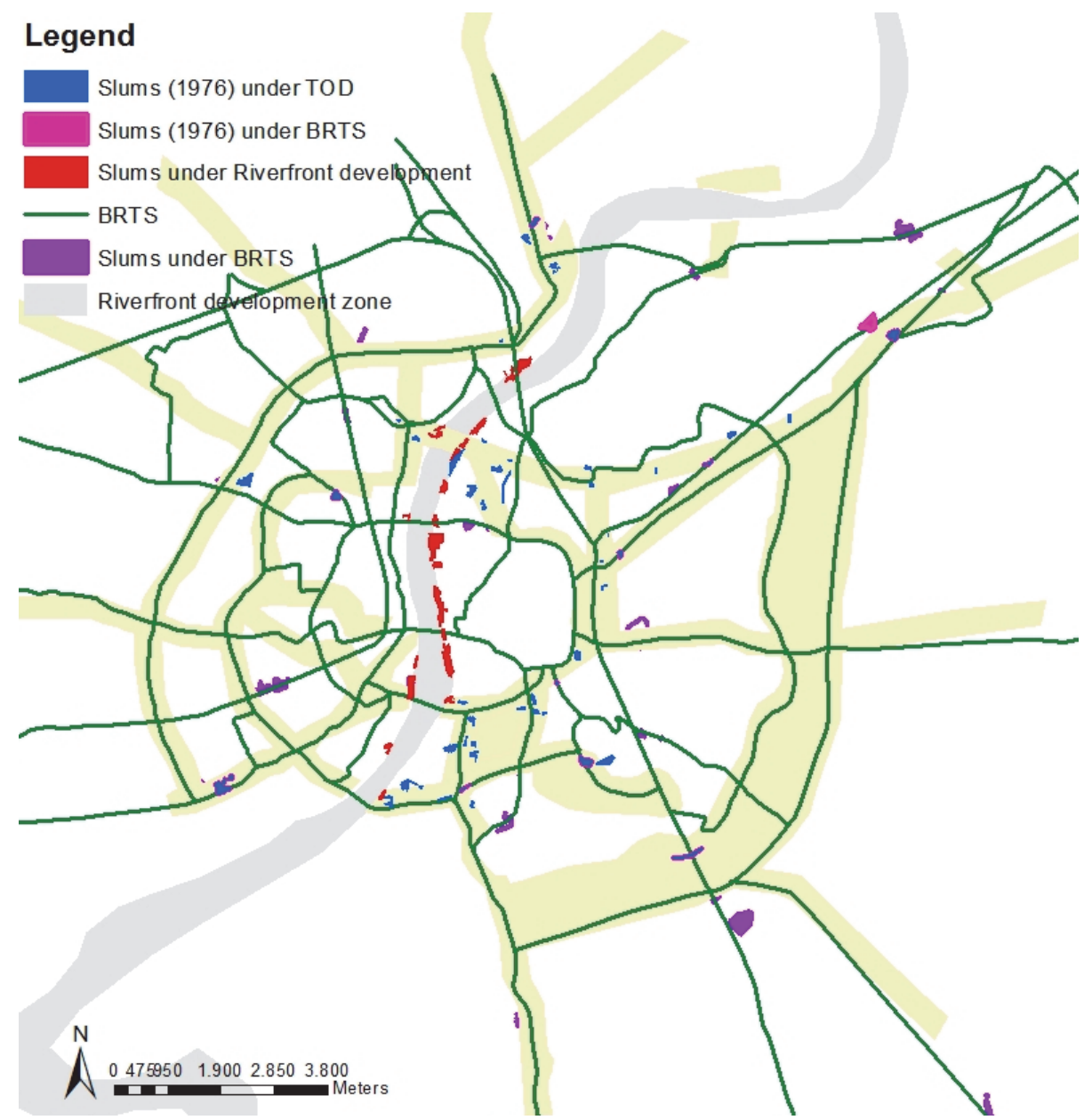

Figure 30: Slums eligible for compensatory shelter on eviction (1976 surveyed and 2002 surveyed in riverfront)

Source: Compiled by author from sources (AMC, NGOs,Primary surveys from 2010 to 2014)

Third, the neoliberal socio-spatial reconfigurations are implemented by new governance entities (Special Purpose Vehicles - SPVs) that exist outside the local state. Their decisions are made by actors not directly accountable to the local electorate and conventional democratic control, based on the rhetoric of efficient delivery and fast track development (Purcell, 2003). SPVs are opaque entities which do not publicly disclose the master plans or the list of persons affected by the projects. Right to Information (RTI) queries are met with vague and irrelevant responses. SPVs are major contributors to eviction of slums for riverfront development, BRTS and MRTS projects respectively (Figure 28 and 29). Though these projects are marketed as being self-financing, the social 
cost of rehabilitation of evicted "eligible" slum dwellers is offloaded to subsidized public housing under Basic Services for Urban Poor (BSUP) and the exclusion of many displacees through the exclusionary cut-off date, clearly increases impoverishment and offloads further social and economic impacts to the displaced and also to an extent to the wider community.

Fourth, analysis of dispossessed households in different stages of resettlement shows that all forms of impoverishment proposed by Cernea (2000b) have emerged, in varying degrees. Relocation distance is the most significant cause of post-displacement impoverishment; most of the impoverishment found amongst displaced populations (such as joblessness, lack of access to community facilities, health risks and social disarticulation) derive from displacement distance. Similar research on Indore has demonstrated that those resettled on-site were substantially less impoverished than those resettled off-site. Many households experienced very high levels of "uncertainty" emerging from lack of information and exclusion from all aspects of planning and implementation of resettlement process. I propose that IRR framework should include "uncertainty" as an additional form of impoverishment and this should be recognized in risk mitigation plans through promotion of high levels of community participation and information sharing through the resettlement process.

Fifth, despite a large body of evidence on the impoverishment of displacees, there was little in BSUP policy that specifically acknowledged or targeted the various components of impoverishment post-resettlement. The BSUP policy included only token reference to impoverishment risks such as relocation distance, joblessness, homelessness, loss of access to community facilities, health risks and social disarticulation; while food security and social marginalization were completely ignored. In instances where there was relevant policy, the realities of implementation by local government did not match the rhetoric. This evident gap between the policy rhetoric and practice of local government has led to impoverishment risks becoming a reality and resettlement a failure. The failure of resettlement is also attributed to dysfunctional communication and lack of transparency between decisionmakers and affected slum communities and the consequent lack of understanding of the latter's needs and aspirations, leading to further impoverishment of displacees.

\subsubsection{Main question}

The tensions between decentralisation and neoliberalisation, explored progressively through the three research sub-questions leads to an answer to the main question of this thesis: How do the tensions between decentralisation and neoliberalisation shape the rights of the citizens and the socio-spatial order 
of neoliberal Ahmedabad? The conceptual framework is further refined by empirical findings, as shown in Figure 31.

First, though under decentralisaton reforms participatory spaces are mandated by all three levels of government they are not brought into practice. Such spaces are deemed to be inefficient and inappropriate for efficient service delivery and urban development. Hence where both processes coexist, the neoliberal bias of local governance closes "invited" spaces with negative implications on the marginalized groups and their ability to negotiate their socio-economic rights. The neoliberal State (in policy) and local governments (in practice) are able to maintain closed spaces with the backing of the judiciary.

Second, the growing propertied middle class in neoliberal cities is emerging as a larger, more influential and favoured electorate than the poor. Though decentralisation opens up opportunities for the unpropertied citizens to negotiate their needs through elected representatives through clientelism, the latter are more biased towards the elite middle class and more responsive to their needs and aspirations, quite often at the cost of the unpropertied. This deprives the poor of political voice despite the new political rights promised by decentralisation.

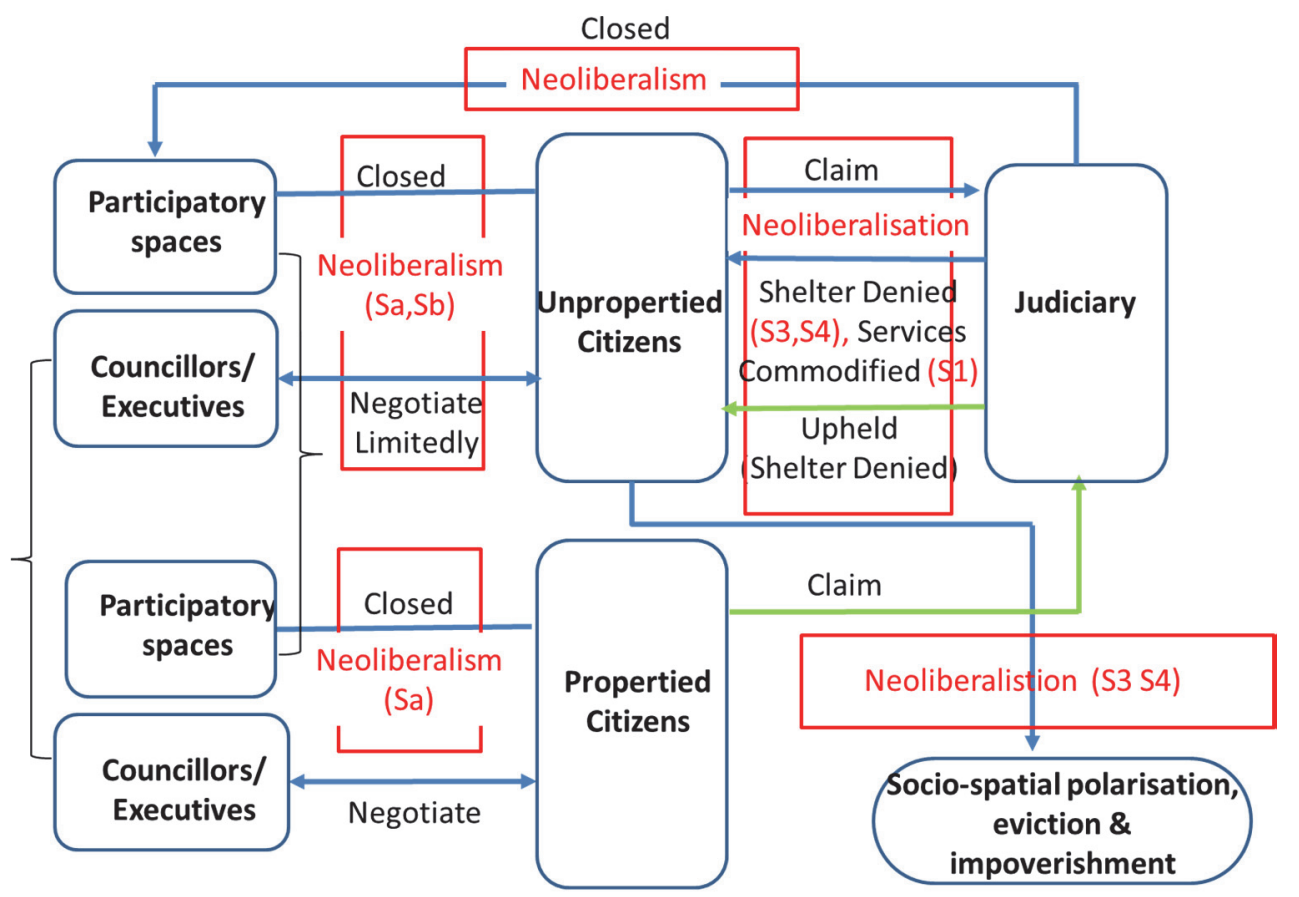

Figure 31: Emerging conceptual framework 
Third, neoliberal projects are implemented through semi-autonomous governing institutions wherein decisions are made by actors not directly accountable to the local electorate and conventional democratic control under the imperatives of capital accumulation and efficient delivery. These institutions do not open to democratic deliberations despite the mandate of participatory governance by the national government. Though the projects by such entities cause a high degree of socio-spatial polarisation through dispossession and impoverishment of the unpropertied, they are absolved from accountability to the electorate. Information on projects is not disclosed to the public and especially the "project-affected community" either actively or passively under the Right to Information Act (RTI). A leading civil society member and planner in a local daily expresses this concern thus: "....Well, there is little that could be done to change or alter what has been constructed already (on riverfront), though it does not absolve the authorities from the responsibility to answering the transparency and accountability questions. It would also help a great deal, if the public questions are answered on the matters of concern without dodging and defeating the spirit of the RTI inquiries. The project is anything but over and it is a "good governance" obligation and the moral responsibility of the authorities to revisit the slum rehabilitation cases that have been denied justice and proper response" (Shah, 2013).

The same also holds true for other projects implemented by such SPVs. Although decentralisation has a sympathetic ring for political legitimacy, it has in fact become a vehicle by the neoliberal local and State governments to confer favours to elite citizens and tasks to semi-autonomous bodies under arrangements that are not democratic, non-transparent and fuzzy.

Fourth, associations of middle class citizens in other cities of India are increasingly filing petitions to the high courts of their States for eviction of slums, framing them as "nuisance" under the environmental laws of India but actually deeming them "unaesthetic" and a "hindrance to the realisation of a world-class image" for their cities, and not in the least as a detriment for their property values. The high courts have been known to show bias to the middle class, and reinterpret the nuisance law and order evictions of slums. In neoliberal cities middle class activism thus often leads to denial of shelter rights and evictions of the poor, and also to wealth accumulation by the middle class.

To sum, the terms of substantive citizenship are reconstituted discursively and materially on the basis of property, where the unpropertied citizens are reconstituted as subgrade, with less political and socio-economic rights than the propertied citizens.

The answer to the main question leads me to an additional question: whether and how information transparency can catalyse the participation of 
unpropertied citizens in neoliberal regimes and enable them to negotiate their socio-economic rights. My research has revealed a "lack of information transparency" or rather "opacity" of the local government to unpropertied citizens as a key contributor to their exclusion from governance process and impoverishment. Further to this, I discuss literature on information transparency policies in terms of effects and underlying assumptions in dialogue with the experience of Indian transparency policies and suggest ways to improve transparency to catalyse participation, especially of unpropertied citizens. 


\section{Chapter 7}

Catalysing citizen participation through information transparency? 


\begin{abstract}
Our research in neoliberal Ahmedabad indicates that information on displacement inducing and slum rehabilitation projects is not shared, lack of transparent information leads to uncertainty for the poor, while litigation in the State's High Court to prevent demolition appears to be the only recourse for unpropertied citizens to claim socio-economic rights. This is rather surprising given the rhetoric of various information transparency policies of the Indian Government. For instance, the Right To Information (RTI) Act (2005) provides an avenue for citizens to force the state to disclose its information archives, including survey maps and data, master planning documents and land titles. The National Data Sharing and Accessibility Policy (2012) offers a digital platform (data.gov.in) for open access to data generated by various government agencies to enable a rational debate, better decision-making and meeting needs of civil society. The Public Disclosure Law Primer (2006), the enactment of which is mandatory for governments of Indian States, promises transparency and accountability in the functioning of local governments. Proponents of such policies view information transparency as a catalyst for citizen participation in governance and a boost to political accountability. However, frustration with the actual practice of transparency in general (Fenster, 2006) and in India in particular (Raman 2012) is widespread and can be partially attributed to three faulty assumptions: First, the state is a monolithic entity, which discloses information if mandated to do so. Second, government information is a discernible message that can be regulated. Third, the public is a monolithic entity awaiting disclosure of this information and responds predictably and rationally. In this paper, we focus on the realities of opacity in Indian cities by using data from empirical work on the changing socio-spatial order of Indian cities. We make two contributions. First, we add to the realities of opacity identified by Fenster (2006). Second, we argue for horizontal information transparency, akin to that pursued by Shack/Slum Dwellers International, which enables social relationships of mutuality and trust (Stalder, 2011) in global and local networks of slum dwellers.
\end{abstract}

Keywords: information transparency, freedom of information, open government data, right to information, public disclosure, opacity 


\subsection{Introduction}

My research in neoliberal Ahmedabad revealed how tensions between decentralisation and neoliberalisation in urban governance shape the rights of citizens and the socio-spatial order of the city. Two aspects of these tensions are: First, although the Government of India (GoI) mandates participatory spaces in decentralisation reforms, the neoliberal State and local governments deem democratic deliberation inefficient and inappropriate for efficient delivery and close participatory spaces with negative implications for marginalized groups and their ability to negotiate their socio-economic rights. Second, the semi-autonomous governing institutions making governance decisions are not directly accountable to the local electorate and subject to conventional democratic control. They are not open to democratic deliberation despite the mandate of participatory governance by the GoI. Information on projects is not disclosed to the general public, or the "project-affected community", under the Right To Information Act, 2005 (RTI Act 2005). Decentralisation is meant only to have a sympathetic ring for political legitimacy but is in fact an attempt by the neoliberal local and State governments to confer favours to elite citizens and tasks to semi-autonomous bodies under undemocratic and nontransparent arrangements. So far, my research has revealed "lack of information transparency", or rather "opacity", of local government to unpropertied citizens as a key contributor to their exclusion from governance process and further impoverishment.

In this chapter, I explore whether and how information transparency can catalyse the participation of unpropertied citizens in neoliberal regimes and enable them to negotiate their socio-economic rights. I discuss a typology of information transparency policies from literature in terms of its genesis, effects and underlying assumptions in dialogue with the experience of Indian transparency policies and suggest ways to improve transparency to catalyse participation, especially of unpropertied citizens. The opacity of the neoliberal State and local governments towards unpropertied citizens in empirical context is evident from the following excerpts of this thesis:

- In contrast to the rise of private sector, the contribution of civil society actors to governance has decreased substantially, power remains centralised and shared with elite capitalists, dissent to the powerful is discouraged, public information is not shared, the middle class has emerged as the favoured electorate and the underprivileged remain marginalised. The so-called "good" governance is primarily for the propertied and the middle class in Gujarat (Shah, 2014: 532, TOI, 2011).

- Those who campaign against corruption in the State by evoking the RTI Act have not fared well. With only 5 per cent of India's population, 22 per cent of the murders and 20 per cent of the assaults on RTI activists in recent years have occurred in the State of Gujarat, which has only two RTI 
Commissioners compared to eight in Maharashtra and nine in Tamil Nadu (Pandey, 2013, Shah, 2014).

- Slum dwellers located within the influence area of displacement inducing and slum rehabilitation projects were evicted without consultations, while those "eligible" to be resettled had no information on the resettlement and rehabilitation policy.

- Their negotiating efforts met with limited success as the State and local government authorities responded with vague assurances of resettling all the slum households to be displaced under Sabarmati Riverfront Development (SRFD) project but did not follow up with concrete actions or share information on the project's resettlement policy. When it became increasingly clear that there was no mention of resettlement in the project, the community's association Sabarmati Nagarik Adhikar Manch (SNAM) stopped the negotiations and instead took judicial recourse by filing a Public Interest Litigation (PIL) in the High Court of Gujarat.

- Exclusion from planning the resettlement processes and lack of transparent information leads to uncertainty in the community even prior to dispossession. It enhances the perception of risk, distracts people from pursuing their economic activities and contributes to impoverishment. I proposed that IRR framework should include "uncertainty" as an additional form of impoverishment and this should be recognized in risk mitigation plans through promotion of high levels of community participation and information sharing through the resettlement process.

- Special Purpose Vehicles (SPV) are opaque entities which do not publicly disclose the master plans or the list of persons affected by their projects. RTI queries are met with vague and irrelevant responses. Though the projects by such entities cause a high degree of socio-spatial polarization, through dispossession and impoverishment of the unpropertied, they are absolved from accountability to the electorate. Information on projects is not disclosed to the public and especially the "project-affected community" when they seek information under RTI.

\subsection{Review of extant literature on information transparency}

In this section, I review literature on information transparency policies, including their effects and the underlying assumptions, in dialogue with the empirical context.

\subsubsection{Rise of open government and typology of transparency policies}

Openness of government has a long history going back to ancient Chinese and Greek thought (Hood, 2006). Nowadays, "openness" and "transparency" are often used interchangeably, or even simultaneously, as in "government should be open and transparent." Heald (2006) attributes the popularity of dual use to the different audiences targeted at the same time. "Openness" addresses 
non-specialists; "transparency" is reserved for specialist audiences. A useful way to distinguish between the two is by thinking of "openness" as a desirable attribute of government and of "transparency" as a relation between government and external receptors capable of processing the information made available and acting upon it (ibid).

I follow Meijer et al. (2012) and define openness of government as having two components: transparency and participation. Transparency is the informational component of openness. It refers to open access to government information, and allows citizens to "see" government and monitor its actions. Participation is the interactional component. It refers to open access for citizens to decision making arenas, and allows citizens to "speak" and influence government decisions. When combined, the two components of openness-informational and interactional-are the foundation of "informed debates" between the governors and the governed. Openness, "seeing" and "speaking", strengthens public accountability, the hallmark of modern democratic governance. Without accountability, "democracy remains a paper procedure if those in power cannot be held accountable in public for their acts and omissions, for their decisions, their policies, and their expenditures" (Bovens, 2005:182).

Research on transparency is required on normative, technological and empirical grounds. First, citizens in an information society should have informational rights, in addition to their traditional civil, political and socioeconomic rights (Bovens, 2002). Second, the diffusion of information technology in society warrants a sustained effort to examine its potential for informed debates between citizens and government since "the further one moves along the spectrum of actions from transparency to participation, the more vexed the idea of digital democracy becomes" (Starr, 2010:4). Third, unless we shift our empirical focus to the South, we are likely to miss social experiments in transparency, initiated by civil society associations working in tandem with mainstream local media, or by governments acting as facilitators and conveners (Fung et al., 2010, Avila et al., 2010). 


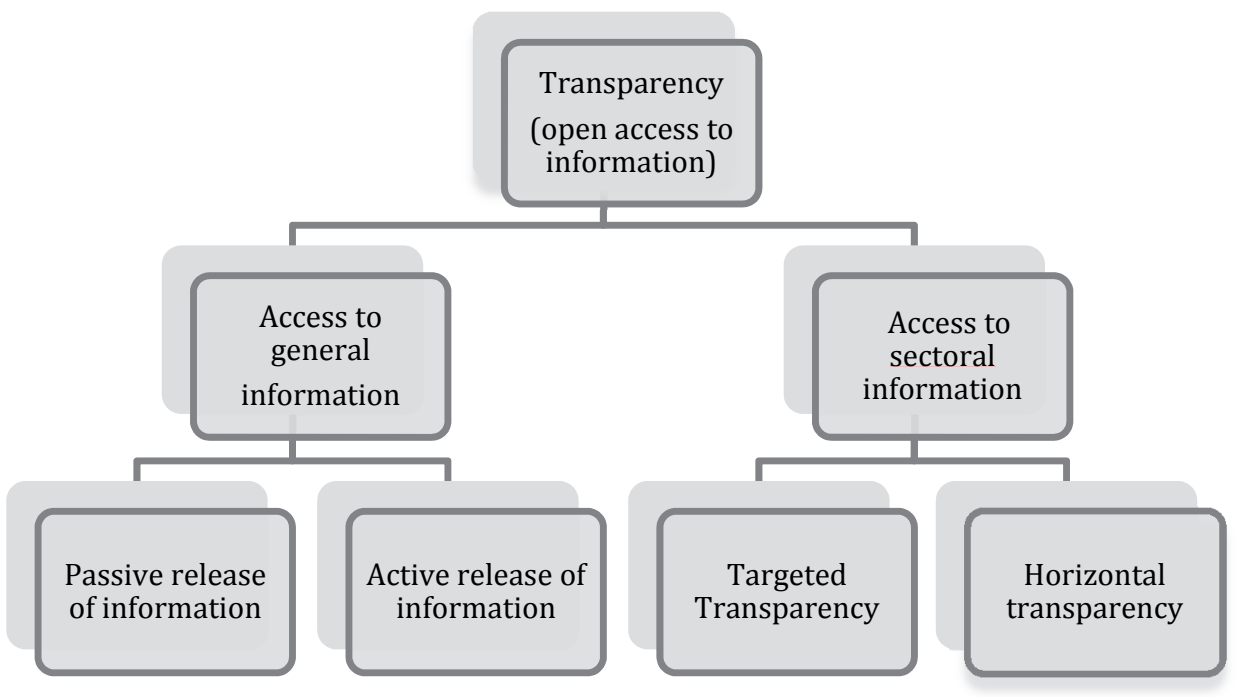

Figure 32: Typology of transparency policies (adapted from Georgiadou et al. (2014))

Here, we focus only on transparency, the informational component of openness. Open access to information is a prerequisite for participation in decision making arenas (Meijer et al., 2012). Without information symmetry between the state and civil society, informed debates cannot take place. Figure 32 shows a typology of transparency distilled from various strands of literature-legal and political science, media theory, political economy of transparency and development studies-that features two distinct levels. The first level distinguishes between the kind of information (general versus sectoral) released. The second level distinguishes between modes (active or passive, targeted or horizontal) of facilitating transparency. In the following section, I discuss each transparency type in detail.

\subsubsection{Access to general information}

The first type of transparency policy facilitates "access to general information." The disclosed information is deemed general in that it does not apply to any specific government sector or policy domain. It includes two sub-types: passive release of information and, its recent digital variant, active release of information.

Passive release: Laws for Freedom of Information (FoI) exemplify passive information release. FoI laws oblige the state to release information to citizens who claim their "right to know" (Fenster, 2012). FoI laws mandate 
passive release of all government records unless specifically exempted by the law itself. The advent of the internet played a major role in the move from passive to active release of information. The influence is visible in the FOI laws themselves. One of the youngest FOI laws, the Indian RTI Act (2005) encourages use of internet for proactive government information disclosure (Roberts, 2010).

Since the 1980s, FOI laws have been adopted in many countries, especially after the post-cold-war democratization wave (Ackerman and SandovalBallesteros, 2006). Drafting and enacting of FOI laws is influenced by international actors, for instance by the World Bank or Transparency International (Roberts, 2010) and political activism and advocacy. The latter play a crucial role in passing, implementing, and enforcing FOI, but also in keeping FOI regulation intact once it exists. For example, the Indian RTI Act (2005) was enacted as a result of the National Campaign for People's Right to Information (NCPRI), a federation of more than a hundred activist organizations. Attempts by the Indian government to restrict the RTI Act six months after its enactment failed due to pressure from civil society groups (Raman, 2012, Roberts, 2010). Under provisions of the RTI Act any citizen of India may request information from a "public authority" (as defined in the Act), which is required to reply expeditiously or within thirty days. The Act also requires every public authority to digitise their records for wide dissemination and to proactively disclose specified categories of information so that citizens need minimum recourse to request information formally (Government of India, 2005).

Countries' FOI laws differ in terms of coverage, exemptions, enforcement and ease of access; and their success and form depend on progress of democracy, external pressures, and a country's history (Ackerman and SandovalBallesteros, 2006:89). The Indian experience shows that getting information under RTI can be a time and spirit-sapping ordeal. Instances of dilatory tactics, levying of unlawful or inflated fees, and even outright refusal, far outnumber the success stories of full and accurate information received and, even rarer, corrective action taken. The Chief Information Commissioner's office has taken up only a handful of complaints about information being denied and in none of these cases has anyone been penalized. Activists are frustrated when, even after uncovering conclusive information, they are still unable to prevail upon the state to take action. A veteran activist with a Delhi-based NGO working with slum-dwellers, declared: "the government has handed the poor a child's rattle to distract them. Have corruption and scams reduced as a result of RTI" (Baviskar, 2010)? RTI's focus only on public accountability is inadequate when corporate practices become consequential in public life. Semi-autonomous bodies such as Sabarmati Riverfront Development Corporation Limited (SRFDCL) and Ahmedabad Janmarg Limited (AJL) are able to deflect RTI 
queries. A more complex issue with implications for the RTI is the gap between law and justice. In neoliberal regimes, laws enforce contracts and uphold property rights, but do not deliver social justice, forcing the unpropertied to violate the law in order to survive. The RTI is used against the interests of poor illegally cultivating Forest Department land or "encroaching" on land while living in slums. In the abstract, the Act empowers all citizens; in practice, it often does so in ways that further jeopardizes the survival strategies of the poor (Raman, 2012, Baviskar, 2010).

Active release: Open Government Data (OGD) initiatives epitomize active information release. Open Government Data (OGD) initiatives entail the active release by government agencies of raw, machine-readable, high-value information in open formats. High-value information is defined as "information that can be used to increase agency accountability and responsiveness; improve public knowledge of the agency and its operations; further the core mission of the agency; create economic opportunity; or respond to need and demand as identified through public consultation" (Memorandum Office of Management and Budget, 2009:7)OGD initiatives often take a laissez-faire approach. Government passes on to individual agencies the responsibility of making open government plans and deciding on the data to be released. Agencies thus have the discretion to decide which previously unpublished "high-value" raw data they can place on a national data.gov site (Shkabatur, 2012).

The National Data Sharing and Accessibility Policy (NDSAP) (2012) of Government of India (GoI) epitomises a step towards OGD. NDSAP claims to provide a platform for open access to the data generated by various government agencies to enable rational debate, better decision-making and meet needs of civil society. It applies to all shareable, non-sensitive data available either in digital or analogue forms but generated using public funds. Government-owned shareable data (along with usage metadata) in machine readable form is claimed to be released through a wide area network all over the country and periodically updated (Government of India, 2012). Following the promulgation of the NDSAP policy, the OGD platform of GoI was launched (data.gov.in) in October 2012, but the data disclosed and its use is limited, as is evident from the number of downloads (till August 2016) on its dashboard (Figure 33). The observable slack on the part of agencies (ministries, state government departments, subordinate offices, and autonomous bodies of government) in complying with the NDSAP can be attributed to three factors (Agarwal, 2016). First, the agencies either do not comprehend the economic value that OGD can generate to both upstream and downstream users of OGD, or suffer from resource and capacity constraints to implement it. Second, consumers (users) are either unaware of India's OGD platform or prefer to use web portals of agencies because of familiarity and/or ease of access. Third, 
there is limited or no interaction between information suppliers and consumers, which highlights the growing wedge in the actual quantity and quality of uploaded datasets on the platform and what is required.

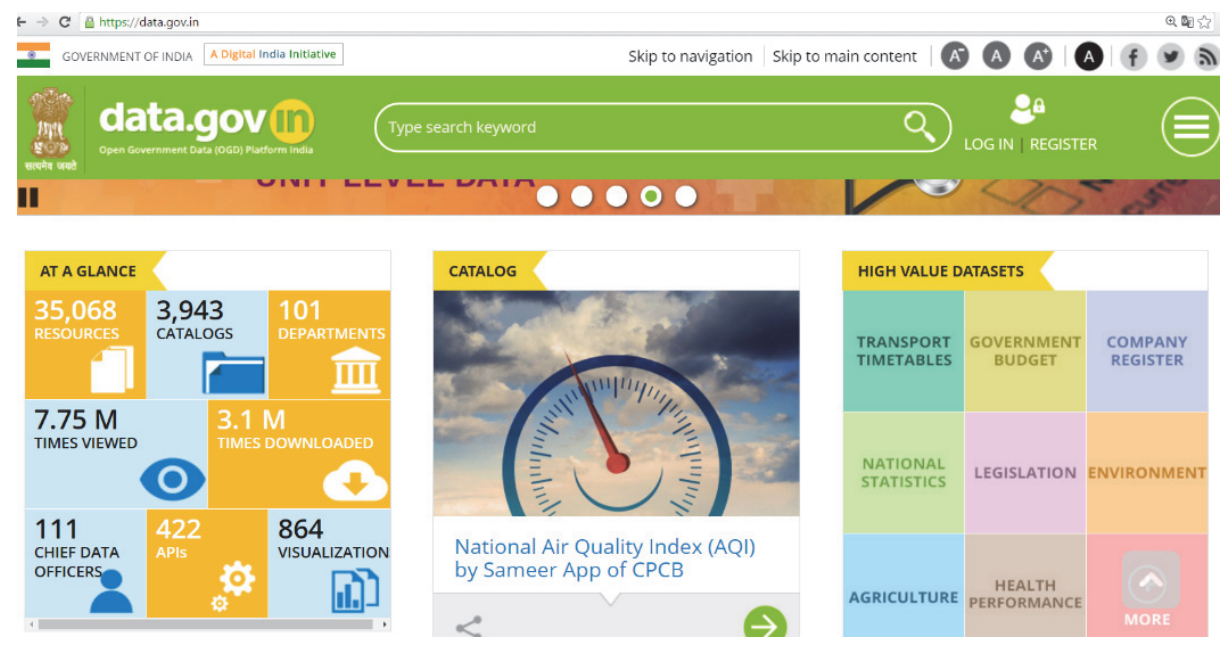

Figure 33: OGD platform of Government of India

FOI/RTI and OGD policies are similar in their aim to make general government information widely available and to ensure accountability and transparency. They differ in that FOI/RTI movements are rights-based, while OGD movements are technology-driven. In India this is evident in the fact that RTI Act 2005 is implemented by the Ministry of Law and Justice whereas NDSAP is implemented by the Ministry of Science and Technology and the OGD site is supported by Ministry of Electronics \& Information Technology. Also, their respective proponents and defenders generally differ in background and the kinds of information or data they target. The focus of national governments and public authorities on OGD may be "distracted" from providing accessible information to the general public in favour of making data portals for developers, and empowering only the latter. In addition, the emphasis on proactive dissemination of OGD may actually have a negative influence on the demand-side of FOI/RTI as public bodies who have to make choices in assigning their limited time and resources will focus more on disclosure to general public for larger goodwill than on responding to individual queries for specific information (Janssen, 2012).

\subsubsection{Access to sectoral information}

The second transparency type is "access to sectoral information". The disclosed information is sectoral because it applies to a specific government sector or policy domain, e.g. municipal information, environmental risks, public health. It includes two sub-types: targeted and horizontal transparency. 
Targeted transparency: This policy type mandates specific private and public agencies to publicly disclose factual information, in standardized, disaggregated, comparable formats, concerning specific practices (municipal finances and operations, master plans, amounts of toxic pollution at a location, water quality). Targeted transparency policies further specific public policy objectives such as improved efficiency in operations and finances, reduction of toxic pollution, improvement of public drinking water supplies (Fung et al., 2007). They are underpinned by laws such as Public Disclosure Law reform in India for municipalities, the Emergency Planning and Community Right-ToKnow Act (1986) in the USA which established the Toxic Release Inventory database, and the Safe Drinking Water Act (1974). Targeted transparency policies started as unplanned inventions by political entrepreneurs responding to crises in the second half of the past century. Over time, they have been applied to the full range of public policy problems, traditionally addressed by regulation based on standards and market incentives (ibid).

The Indian government mandated Public Disclosure Law (PDL)in 2006 as a prerequisite for state governments to avail grants under the Jawaharlal Nehru national Urban Renewal Mission (JNNURM). The goal was to institute transparency and accountability in the functioning of Urban Local Bodies (ULBS) through quarterly disclosure of information on facets of municipal governance, such as personnel, administrative structure, finances and operations, promote efficiency and consistency in the delivery of public goods and services by ULBs and enable comparison over time (of a particular ULB) and space (between ULBs) by disseminating information in a structured, regular and standardized manner (Government of India, 2006e). PDL was envisaged to enable citizens to effectively use the participatory platforms of Ward Committees and Area Sabhas to influence municipal policies and negotiate rights. Thus PDL supplemented another key reform of JNNURM, the enactment of Community Participation Law (CPL), by helping achieve informed participation. It was also envisaged to supplement RTI Act (2005) by suo-moto making available regular information on ULB activities which would ease the load on the Information Department by reducing number of RTI requests on such matters (Government of India, 2006e). Though the Government of Gujarat (GoG) and the Ahmedabad Municipal Corporation (AMC) had agreed to implement PDL by 2007, through a Memorandum of Agreement (MoA) with GoI in 2006 (Government of India, 2006c) as shown in Figure 34, the State PDL statute is neither publicly disclosed nor clarified whether it is enacted. Opacity of information on various facets of municipal governance persists as has been highlighted throughout the thesis and summarised in the section 7.1 of this chapter. 


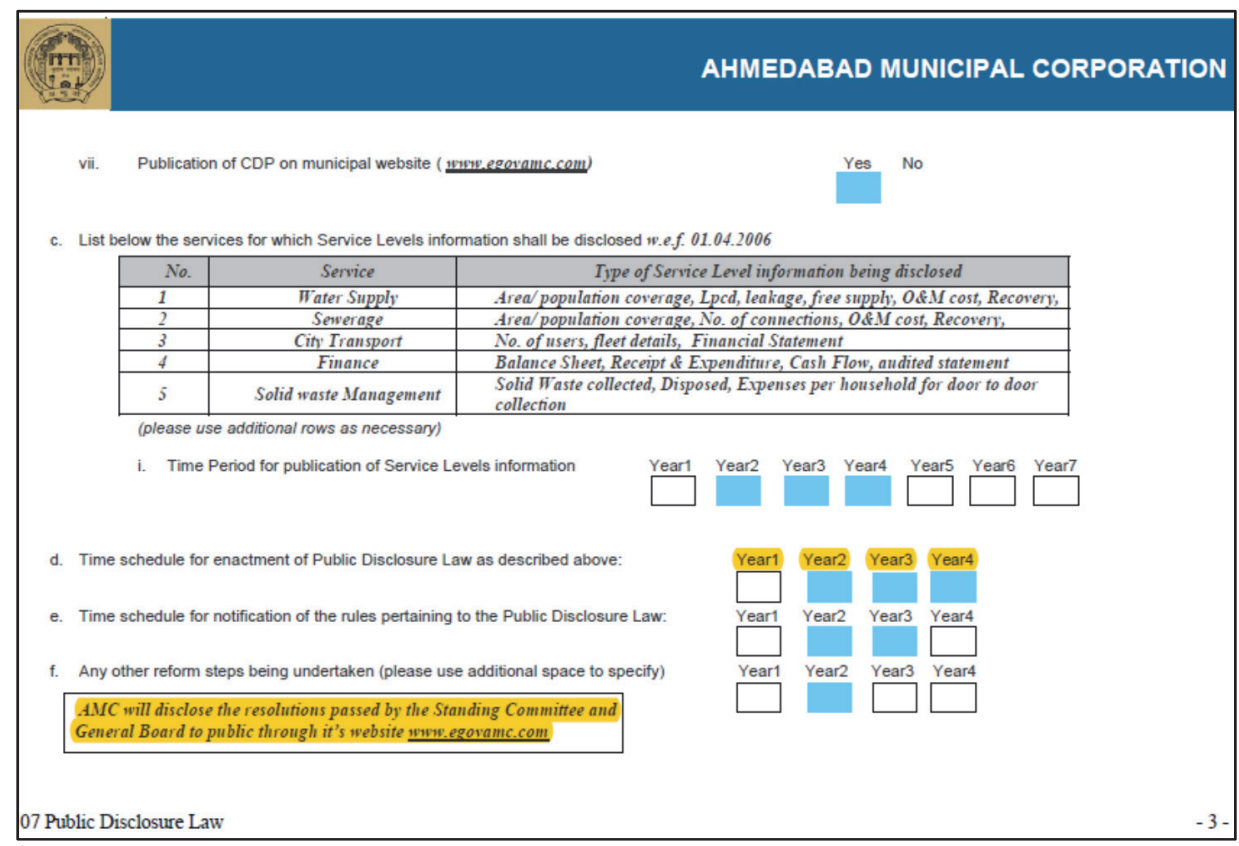

Figure 34: GoG and AMC's commitment on enactment of Public Disclosure Law in MoA with Indian government

Horizontal transparency: The second sub-type of access to sectoral information, aims to create a level playing field between citizens and government, where citizens (co-)produce information about specific functions of government such as ward budgets, public service delivery, slum maps and enumerations.

Stalder explains the need for a horizontal paradigm of transparency, that extends sociality to large scales and counteracts globalization and neoliberalism. He writes: "We must differentiate between different modes of transparency and the social relationships they enable. Transparency within the liberal conception, in its nineteenth- and twenty-first-century forms, takes the existence of hierarchical state institutions and of power through representation as a given, but aims to balance it with what one might call "bottom-up" visibility. Because it recognizes that the state is based on a design in which institutions concentrate power, it needs mechanisms to hold those inside these institutions - that is, those who hold power - accountable to those outside whom they are supposed to serve. These relationships of accountability should not be casually dismissed, but they no longer suffice, because power no longer operates merely through institutions but increasingly through standards. These currently dominant standards demand particular forms of transparency that, in effect, create a kind of "top-down" visibility, whereby those with substantial information-processing capacities can adjust, more or less subtly and to their 
own benefit, the conditions under which all others operate as "free agents". Rather than work through commands, power operates through the seemingly neutral formulation of "if . . . then" propositions. The transparency of the social body ensures that these propositions are subtle enough to be read as statements of facts, rather than as acts of coercion. If we accept that standards are ways to enable the social coordination of autonomous agents (that is, those outside hierarchical command-and-obey structures) we need to develop different standards that are not infused by the neoliberal programme. If we accept that contemporary sociality needs to operate on a global scale, we need to find ways of articulating mutuality on that scale. A precondition of this is a form of visibility that allows for the synchronization of actions without feeding the machine of cybernetic control. Thus, we need a paradigm of transparency that is strictly horizontal, that enables us to extend sociality to a very large scale. This requires new standards of communication, new tools of communication that actively support the experience of mutuality and actively prevent the implementation of top-down visibility" (2011:8).

An example of horizontal transparency is practiced by Shack/Slum Dwellers International (SDI), a global federation of slum communities spread across thirty three countries on four continents. Appadurai describes SDI as "a series of social forms that has emerged to contest, interrogate, and reverse marginalization (of the unpropertied) and to create forms of knowledge transfer and social mobilization that proceed independently of the actions of corporate capital and the nation-state system[...] These social forms rely on strategies, visions, and horizons for globalization on behalf of the poor that can be characterized as "grassroots globalization" (2000:3). SDI communities collaborate amongst themselves and with the state to co-produce information through "self-enumeration and mapping" of slums and thereby build a community, define a collective identity, facilitate development priority-setting and establish a basis for engagement with the government (Patel et al., 2012). For example, SDI's affiliate (the Indian Alliance), an alliance of a NGO (SPARC), National Slum Dwellers Federation (NSDF) and a women's savings co-operative (Mahila Milan), partnered with the Cuttack Municipal Corporation, co-produced enumeration and mapping data of slums and succeeded in getting the data ratified by the state so that it can be the basis for determining land tenure and planning slum development (Livengood and Kunte, 2012).

The local government compiles slum lists and maps through surveys outsourced to third party or private agency and sets standards for "acceptable" information. Inclusion in the list and map depends on people's socio-political relations with local politicians and bureaucrats, and on varying intentions and alliances fostered in the process (Richter, 2011). Ethnographic research shows that the boundary between state and citizen is blurred, redrawn and renegotiated through day-to-day practices, in which citizens and 
representatives of the state encounter each other (Gupta, 2006). As a result the state prepared slum census and maps are usually contested by slum communities and remain unratified. My thesis reveals this fact in the following excerpt in section 1.4.2: "After the 1976 survey and notification of slums, AMC commissioned Non-Governmental Organisations (NGOs) and private agencies to conduct surveys, for enumeration and mapping of slums, in 1992, 2001, 2010 but none of the three surveys was ratified. Contestations around enumeration and mapping between slum community leaders and councillors are believed to be one of the primary reasons. The 1992 and 2001 surveys were outsourced to NGOs and the 2010 survey, as part of settlement and household biometrics enumeration mandated under Rajiv Awas Yojana program, was outsourced to a private consultant." SDI counters this "top down" information about themselves by setting own information standards for the information and forcing the state to come to the negotiating table and "ratify" the information.

\subsubsection{Effects of transparency}

The release of government information has several democratic benefits. Release of information can legitimate government, enable informed individual choice and collective decision making. Especially for developing countries transparency's capacity to curb corruption is emphasized (Fenster, 2012, Roberts, 2010). Transparency reduces the costs of secrecy, allows the free flow of information to review and criticize government action, and enables more peaceful international relations (Fenster, 2006, Meijer, 2009). In addition, government-held data released under "open government data" initiatives can foster technological creativity and scientific advancement ( $\mathrm{Yu}$ and Robinson, 2012). But the devil sits in the detail and transparency can be criticized on a number of grounds. As is the case with other laws and regulations, how a FOI law is authored, drafted, implemented and enforced is problematic. If government is the agency regulating its own disclosures, it can at any point (attempt to) reverse the same regulation. In some cases the law itself is drafted weakly. For instance, Zimbabwe's FOI law imposes strict controls on journalists with the effect of making it more difficult to access information (Ackerman and Sandoval-Ballesteros, 2006). Implementation and enforcement of FOI laws remain difficult and can be tackled in different ways depending on a country's governance structure (Ackerman and SandovalBallesteros, 2006, Fenster, 2006).

Transparency laws have unintended or "perverse effects." For instance, the Administrative Procedure Act (APA) in the U.S.A. "produces the paradoxical result of a law designed to open up government but actually pushes it into obscurity" as officials try to avoid time-consuming APA procedures and instead rely more on informal adjudication not subjected to disclosure (Ackerman and Sandoval-Ballesteros, 2006:108). An analysis of transparency legislature and 
initiatives in the European Union (EU) shows that transparency potentially decreases efficiency and effectiveness of policies, and may even undermine the EU's legitimacy (Curtin and Meijer, 2006).

Especially active release through OGD initiatives is driven by multiple and potentially conflicting motivations. The boundaries between political aims of transparency and commercial interests of technology promoters become blurred (Yu and Robinson, 2012). Because of their entanglement with varied corporate interests and private or semi-private entities open government data initiatives drive the marketization of public services, favour those, who are already empowered, ignore issues of privacy, or claim to increase political transparency while actually addressing service delivery to citizens ( $\mathrm{Yu}$ and Robinson, 2012, Slee, 2012, Roberts, 2010).

General information release can be questioned with respect to information amount, form and content. Information may not be presented in an understandable or user-friendly form, or may lead to information overload and in turn to more uncertainty (Curtin and Meijer, 2006, Starr, 2010). In the case of open government data initiatives, it is questionable in how far general data held by the state, such as Census or physical environment data (especially in "raw" form) can provide any insights into government performance (Brito, 2001). Furthermore, the complexity of government information requires many documents to be viewed together in order to gain genuine insight into government performance or requires to systematically collect and re-assemble online datasets (Stalder, 2011, Yu and Robinson, 2012). Finally, information transparency is unidirectional. It is not possible for the citizen to ask questions back and to sanction the information provider in response to released information, a necessary step in the accountability cycle according to Bovens (2007). In sum, the early "enthusiasms have run up against stubborn and uncomfortable limits" (Starr, 2010:5). What explains these limits?

\subsubsection{Assumptions of transparency}

To answer this question we follow Fenster (2006) according to whom frustrations faced by both proponents and sceptics of information release can be partially attributed to three faulty assumptions: The state is assumed to be a monolithic entity, which discloses information if mandated to do so. Government information is a discernible message that can be regulated, and the public is a monolithic entity awaiting disclosure of this information and in response acts predictably and rationally. From this it follows that if information flows from state to public are improved, transparency increases (and democracy is strengthened). These assumptions are based on a classic, linear communication model according to which a message is transmitted from sender to recipient with the message holding a single meaning retained during 
the process of transmission (Shannon, 1948). The same sender-messagerecipient model drives most transparency initiatives discussed in the foregoing. Fenster (2006) identifies several "realities of opacity" that stand in contrast to these assumptions.

\subsection{Empirical context: realities of opacity}

In the following we illustrate realities of opacity within our empirical context. Table 30 summarizes assumptions of transparency initiatives.

Table 30: Assumptions of transparency policies (adapted from Fenster (2006)

\begin{tabular}{|l|l|}
\hline & Assumptions of transparency policies \\
\hline $\begin{array}{l}\text { There is a } \\
\text { sender }\end{array}$ & $\begin{array}{l}\text { Government constitutes a potential sender of its } \\
\text { information, so long as we impose the proper disclosure } \\
\text { requirements upon it }\end{array}$ \\
\hline $\begin{array}{l}\text { There is a } \\
\text { message }\end{array}$ & $\begin{array}{l}\text { Government information constitutes a message necessary } \\
\text { for a functional democracy, so long as it is disclosed }\end{array}$ \\
\hline $\begin{array}{l}\text { There is a } \\
\text { receiver }\end{array}$ & $\begin{array}{l}\text { The public awaits disclosure of government information, } \\
\text { and will act in predictable, informed ways, so long as it has } \\
\text { access to government information. }\end{array}$ \\
\hline
\end{tabular}

\subsubsection{Assumptions and realities of a monolithic state}

Information transparency policies' assumption7.3.1.1 that the state is monolithic and will send information if mandated to do so does not hold.

The state is incoherent. The state consists of multiple agencies with partially overlapping jurisdictions, with complex and emerging relations to private and research entities, and is increasingly tied into international bodies and regulations (Ackerman and Sandoval-Ballesteros, 2006, Fenster, 2006). Because of this complexity, it is difficult for a citizen to find out, where to file a RTI application, which agency is holding certain information, and whom to address for additional information (Raman, 2012, Roberts, 2010). Database designs and format differ due to cost considerations (Raman, 2012), changing survey techniques, an agency's or individual objectives (Richter, 2011), as well as intra-governmental competition over data as a resource (de Vries and Lance, 2011).This multiplicity and heterogeneity severely hampers attempts towards full technical and organizational integration and creates such challenges that the citizen, who would eventually benefit, moves into the shadows. In Ahmedabad, the unpropertied citizens to be evicted by riverfront projects sought information on resettlement policy by filing RTI requests at AMC. However, the requests were transferred from one zonal office to another and then to the SRFDCL, the Special Purpose Vehicle, which only partially answered the RTI query claiming that resettlement was not in its purview, and referred it back to the central AMC office. By that time, the activists and the poor citizens, were frustrated enough to give up on taking further action of appeal to the Appellate Officer of AMC. 
The state is unresponsive even if mandated to disclose information. It is the nature of bureaucracy to accumulate and hoard information and to keep it secret. Fenster (2006) argues, that if we need a certain level of bureaucracy for a functioning democracy, there is bound to be a certain level of secrecy. Even with RTI in place, officials may evade providing the information, give mounts of irrelevant information, or outright refuse to provide the requested information (Baviskar, 2007; Roberts, 2010). For the Indian RTI to bear fruits it took: "years of work, mobilizing collectively to enable very vulnerable people to join and stay in a protracted and arduous battle where success is uncertain, organizing public meetings and protests, persistently pursuing elusive government records, overcoming obdurate bureaucrats and hostile politicians, being harassed and attacked - without these there would be no national Right to Information Act" (Baviskar, 2010:18). In light of the physical attacks on and murder of activists, who made repeated use of RTI applications to uncover cases of corruption in the State of Gujarat and elsewhere in India (Pandey, 2013, Shah, 2014, Baviskar, 2010) we have added the "aggressive state" to Fenster's (2006) list of realities because violent reactions cannot be categorized as "unresponsive".

The state is overwhelmed. Studies on Indian RTI implementation have shown that a lack of infrastructure and equipment, training, the procedure of filling positions, and absence of leadership and planning make it difficult for administrators to respond adequately to RTI inquiries (Roberts, 2010). Richter's (2012, personal communication) experience with a municipal Geographic Information System coordinator illustrates this:

Researcher: Why do you have the municipal development plan and maps (building footprints and existing features) available only on the municipal intranet, and not online for the public to see?

GIS coordinator: We cannot put these maps online, because if people see them and find mistakes, many might come and complain, and we could not respond to all the complaints.

Researcher: But you can put a disclaimer that states that there may be inaccuracies and that the municipal corporation [municipal government] is not responsible for problems when using this map.

GIS coordinator: "No, we cannot do that, because then the people will say that the government is not doing its work correctly."

The Indian state is not the only one to be overwhelmed. In the United Kingdom, a British advocacy group has warned that FOI is threatened by the commissioner's slowness to respond to complaints, and Canada's commissioner has difficulties with backlogs (Roberts, 2010). 


\subsubsection{Assumptions and realities of government information}

The assumption that government information exists in a form that can be regulated does not hold. In reality information can be tweaked, renamed, and re-classified depending on regulations and related exemptions. If the producer of the information is also the author of the laws regulating information, there is no autonomous message. To illustrate Fenster's (2006) statement "(government) information does not exist" we can consider the case of enumeration for families living Below Poverty Line (BPL). A family that listed as BPL can avail benefits of various government schemes including a ration card for subsidized food supplies. The criteria set by GoG for BPL in 2008, when the last enumeration was done, was an income of INR 501 per person per family. The ULB collects data on family income through door-to-door survey of families. To favour some ineligible families, the information is tweaked by adding members to the family so that income per head can be shown below the limit. The anomalies from tweaking BPL information were reiterated by city Municipal Commissioner in a local daily thus: "(in the past) chances are that many families were falsely included in the list and the genuine ones left out" (Devarhubli, September 2nd, 2013).

Second is the case of compensatory shelter to be provided to evicted but "eligible" slum dwellers. When AMC regulates who is eligible for compensatory shelter on eviction, it can tweak the information to favour "ineligible" families and provide them with compensatory shelter, while some "eligible" families may be left out as shown in our research (Patel et al., 2015).The tweaking of criteria was exposed in a local daily thus: "The standing committee also gave relaxation to around 11 slum dwellers by exempting them from producing proofs otherwise required for rehabilitation" (DNA, June 2nd, 2012 ).

Thus regulating (or classifying) information is not a neutral, objective endeavour. It endows the information with meaning. Therefore, there is no (government) information that has one and only one meaning. Rather, the meaning of a given document, dataset, or record depends on the context of its construction, the reader/recipient, and (variable) intended uses of the document or record. For instance, master plans are constructed through the assemblage of information depending on political negotiations and private industry's lobbying(Raman, 2012). The document is not used to plan, but planning decisions are made in the process of constructing the document. The information disclosed may in turn not be understandable to or interpretable by the reader. It may require additional records to make sense and to achieve a given aim (Raman, 2012, Roberts, 2010, Stalder, 2011), require certain communication, format, and legal standards to be accepted be a given audience (Raman, 2012), or require the recipient to "wade through ... masses of documents" in order to make sense of government performance and processes (Curtin and Meijer, 2006:114). 
Furthermore, the medium being used to write, transmit and read information also changes the meaning of information. If an online search database for land records requires the input of a survey number known to real estate developers, not to farmers, the information has meaning only for the developer (Raman, 2012). De facto, this information does not even exist for a farmer who lacks prior knowledge of and access to the survey number or the internet. Meijer (2009) shows that information technology-inspired transparency is "mediated" in three ways. It is mostly one-way as opposed to face-to-face transparency. It is taken away from the context that it refers to. And it has a calculative character, because computers were designed to handle structured quantitative information, not un-structured narrative accounts. In sum, rather than a given piece of government information (a message) being transmitted from sender to receiver, information requires constant translation, re-writing, and reorganizing.

\subsubsection{Assumptions and realities of a homogenous public awaiting disclosure of government information}

Assumptions that a homogenous public awaiting disclosure of government information exists, and can react to the same in predictable, rational, and informed ways do not hold.

\section{The public is not necessarily awaiting disclosure.}

The public is also not coherent, and we may ask, who exactly is the public? For example, in EU available online information is used by civil society organizations more so than individual citizens (Curtin and Meijer, 2006). The question then becomes, whose interests are represented by these organizations? In light of the links between open government data initiatives and the interests of real estate and information technology industries (Benjamin et al., 2007, Raman, 2012, Slee, 2012, Raman and Bawa, 2011)one also has to ask, if the public includes commercial and private industry? If commercial lobbies influence the type and method of information release, the method likely serves these commercial interests more than others. This lies at the heart of Slee's (2012) critique of the open data movement: "insisting that data is and can be accessible to rich and poor alike, like justice and the Ritz." Whether a member of the public can make use of online data depends on educational level, gender, income and other background characteristics (Gurstein, 2011). The same holds for offline forms of information release. People vary in their perceptions of usefulness and enforcement potential of FOI laws, their abilities to afford payment of disclosure fees, awareness that FOI laws exist, and insecurities and fears to address the state apparatus (Roberts, 2010). Our research shows that middle class citizens successfully use egovernance and m-governance platforms of Ahmedabad Municipal Corporation for grievance redressal, whereas the majority of the respondents from unpropertied citizens were unaware of these platforms (Patel et al., 2016). 
The use of information also depends on the individual's or group's social and political relations. If and how marginalized urban poor succeed in claiming socio-economic rights such as basic services and compensatory shelter by means of the RTI Act is by the group's socio-political standing in the city and its relations with executives in ULB (Raman, 2012). Thus in addition to the "incoherent public", we have an "overwhelmed public" with and abundance of information to sort through, or requiring programming and other technical skills to make sense of available data.

Third, there is the "sending public", when non-state agencies co-produce government information. One example is the compilation of official lists and maps of so called "slums" and related beneficiaries of housing and infrastructure programs by city governments in India. The meaning of these lists depends on people's socio-political relations with local politicians and bureaucrats, and on varying intentions and alliances fostered in the process of listing (Richter et al 2011). Ethnographic research shows that the boundary between state and citizens is blurred, redrawn and renegotiated through dayto-day practices, in which citizens and representatives of the state encounter each other (Gupta, 2006). Why is this reality important to add to Fenster's account? Policies, laws, and technologies that claim to increase transparency set different standards of what is acceptable information for a given purpose and audience. If the standard is to prove performance based on GIS analysis, performance cannot be proven on the basis of a poem, no matter how succinctly it may reflect performance or processes. Because citizens have different capacities and goals, their ability to participate in the construction of acceptable information depends on standards.

Table 31: Adapted from Fenster (2006) with additional reality characteristics

\begin{tabular}{|l|l|l|}
\hline & Assumptions of transparency & Reality of opacity \\
\hline $\begin{array}{l}\text { There is a } \\
\text { sender }\end{array}$ & $\begin{array}{l}\text { the government constitutes a } \\
\text { potential sender of its information, } \\
\text { so long as we impose the proper } \\
\text { disclosure requirements upon it }\end{array}$ & $\begin{array}{l}\text { The incoherent state } \\
\text { The unresponsive state } \\
\text { The aggressive state } \\
\text { The overwhelmed state }\end{array}$ \\
\hline $\begin{array}{l}\text { There is a } \\
\text { message }\end{array}$ & $\begin{array}{l}\text { Government information constitutes } \\
\text { a message necessary for a } \\
\text { functional democracy, so long as it is } \\
\text { disclosed }\end{array}$ & $\begin{array}{l}\text { Government } \\
\text { information does not } \\
\text { exist \& has not meaning }\end{array}$ \\
\hline $\begin{array}{l}\text { There is a } \\
\text { receiver }\end{array}$ & $\begin{array}{l}\text { the public awaits disclosure of } \\
\text { government information, and will act } \\
\text { in predictable, informed ways, so } \\
\text { long as it has access to government } \\
\text { information. }\end{array}$ & $\begin{array}{l}\text { The incoherent public } \\
\text { The overwhelmed public } \\
\text { The sending public }\end{array}$ \\
\hline
\end{tabular}

\subsection{Discussion}

The above illustrations support Fenster's argument that the assumptions underlying transparency do not hold in reality and that they are at the root of 
frustrations encountered by those who hope that transparency policies and initiatives will live up to their expectations as well as by those who are more doubtful. The reality of opacity requires us to ask the same questions that Bovens (2007) asks with respect to transparency and accountability: Who should render an account? About what should this account be? To whom is the account to be rendered? And why should somebody be obliged to render the account?

In transparency the focus on information in and of itself is problematic. Laws, policies and initiatives for transparency are made by the government to regulate government information. Not only is the information adjusted by those who were involved in its making (indeed, during the process of making decisions and policies) and subsequently release this information, but transparency laws and policies themselves can be amended or reversed by those, who initiate and draft them. The focus on information also fails to take into account the relations between sender(s) and receiver(s). Paradoxically, general information release transparency claims to improve precisely these relations, whether it is within government (like SDI programs), or between state and the public (like FOI and OGD). How can a policy or law regulating messages address the following problem: a socio-politically weaker citizen (incoherent public) is scared to meet the hostility of public authorities (the unresponsive or the aggressive state) and therefore never files a RTI application (Roberts, 2010)? No message that can be regulated plays a role in this dilemma. These regulations "rest on the ill-founded hope" of "objectivity (of information) and (the) capacity of transparency to bypass murky politics" (Stalder, 2011:17).

In the case of active release of information, the causal link between information release, transparency, accountability and legitimacy are even more difficult to establish. Since the mixing (????) of open government data initiatives the word 'open government' no longer entails transparency in its political connotation, namely to strengthen democracy. This ambiguity makes it difficult to identify and predict, who would or does benefit from these initiatives (Yu and Robinson, 2012). As long as any information is disseminated, the policy appears successful, but many datasets are not about government performance or decisions. Open government data initiatives fail to address "murky politics" altogether.

Fenster (2006) argues for more time and context specific transparency policies. Similarly, Ackerman and Sandoval-Ballesteros (2006) argue that the spread of "disclosure laws" (sectoral information release) may offer solutions in light of "shrinking governments" or "withdrawing state" and the privatization of previously public tasks. For Ackerman and Sandoval-Ballesteros the shrinking government is a given condition, to which transparency policy has to adjust. 
Slee (2012), on the other hand, argues that open government initiatives also contribute to privatization, and are used to foster this process. In his blog, he concludes that addressing the problem "will require putting far more emphasis on experimentation in standards, licensing, and selective provision of data." Stalder (2011) critiques transparency regimes that promote top-down visibility and control through standardization and integration. He calls for horizontally organized transparency through "small acts of trust ... made possible through particular forms of visibility" (2011:17). Regarding open government/data initiatives in the U.S. Yu and Robinson (2012) in line with some voices in the White House advice to (re-)separate technological from political "openness" and focus on political questions that motivate transparency in the first place.

Ongoing experimentation in implementing and using RTI has broken new ground in India in that it extends to NGOs financed through government, and this addresses the "incoherent sender". Indian policy has also begun to absorb RTI principles into other legislation that addresses specific problems, such as municipal governance (it re-embeds an information-centered law into a specific policy problem arena). Further experimentation in Indian cities may include a shift in transparency policies from the "general" to the "particular," from the "long-term" to the "situation-specific", from "vertical" to "horizontal," and from "integration" towards "sectoralization". These shifts may catalyse participation of unpropertied citizens in neoliberal local government. 
Chapter 8

Reflection and future directions 


\subsection{Reflection}

In this section I first reflect on contributions this thesis makes to knowledge on urban governance and its limitations. In the last section I will sketch three directions for future research and practical implications for urban governance.

\subsubsection{Main contributions}

First, the most important contribution of this study pertains to advancing the knowledge on new forms of urban governance. Global economic restructuring involves the simultaneous implementation of neoliberalisation and decentralisation reforms in urban governance. These reforms are being implemented in cities across the globe and though they are interlinked and simultaneously implemented processes (Purcell, 2003, Goodwin and Painter, 1996, Purcell, 2002) little is known about the consequences of simultaneous implementation of both reforms in urban governance. This is the only empirically grounded research to critically reflect on tensions between the two and consequences of these tensions for rights of citizens and the social-spatial order of city and especially in Indian cities.

Second, within the empirical context of India the research is timely and relevant. As the neoliberal governance model of Gujarat and Ahmedabad become ideals for other cities of India, the perils of neoliberalisation prevailing upon decentralisation are made explicit through the research.

Jawaharlal Nehru National Urban Renewal Mission (JNNURM) has paved the way for the "Smart Cities Mission", initiated in 2015 by the newly elected Prime Minister and his political party (National Democratic Alliance) with the infusion of hefty funds (INR 500000 million or USD 7500 million) into 100 cities for "smart city" development. Not surprisingly, the rhetoric is similar to Gujarat's: "Minimum government and Maximum governance" and "Government has no business to do business." Projects in cities will be mooted through Special Purpose Vehicles (SPVs) with the objective to "ensure operational independence and autonomy in decision making and mission implementation" (Government of India, 2015:1) and "the Mission encourages the State Government and the ULB (Urban Local Body) to adopt the following best practices to create empowered SPVs.... delegating the rights and obligations of the municipal council with respect to the smart city project to the SPV [...] delegating the decision making powers available to the ULB under the municipal act to the Chief Executive Officer of the SPV" (Government of India, 2015:5). With these guidelines, SPVs, like those of Ahmedabad, will be emulated across 100 cities of India. My research on the implications of subversion of democratic deliberation through SPVs and their opacities for marginalised citizens and socio-spatial order of cities lays the groundwork for cities to formulate policies for SPVs that ensure accountability to the electorate. 
Most cities have proposed slum evictions and their substitution by "smart" enclaves as part of smart city plans, with the enclaves inspired by the Sabarmati riverfront project promoted as a model by Government of India in the promotional presentations of the Mission. I quote from one daily reporting on slum evictions under the smart city project in Bhuwaneshwar: "The ambitious smart city project is set to encounter its first serious challenge with the administration planning to evict slum dwellers to revamp and build a housing project on a 985-acres stretch.... the Slum Dwellers" Association's threat to launch an agitation if their concerns are not addressed....leader has claimed that the municipal corporation's survey and its list of beneficiaries were based on 2011 figures and gross injustice..." (Mishra, 2016). Same holds true for the other ninety-nine cities. The empirical research on the consequences of such projects for marginalised citizens and their socio-spatial polarisation is relevant and caution to the upcoming "smart cities" across India.

Third, the research may lay the foundation for Government of India's (GoI) plans to realise UN's Sustainable Development Goal (SDG) 11 which is to "Make cities inclusive, safe, resilient and sustainable" with one of its targets being "to ensure access for all to adequate, safe and affordable housing and basic services and upgrade slums" (United Nations, 2015). Pertaining to this target, my research puts forth evidence of three contradictory practices in a neoliberal city. First, the focus is on eviction and partial resettlement based on arbitrary cut-off dates and not on upgrade as the land is expropriated for other "profitable" uses. Second, basic services are commodified and not affordable to all slum dwellers. Third, access for all remains rhetorical as cities continue with arbitrary cut-off dates for compensatory shelter entitlements. If GoI is serious about its pledge to meet SDGs, taking cognisance of evidence provided in my research will help in meeting them.

Fourth, my research contributes to the Development Induced Displacement and Resettlement (DIDR) framework. This is perhaps the first attempt to validate Cernea's (2000b) impoverishment risks in an urban context and especially in Indian cities. The indicators developed to assess various forms of impoverishment and related findings lay the groundwork for cities of India working on resettlement risk mitigation policy for evicted slum dwellers, including for the 100 Smart cities. As my research has identified "uncertainty" emerging from lack of information and exclusion of the community through the entire process of planning and implementation as an additional form of impoverishment, cities may give more credence to these aspects to avoid resettlement failure. Similarly relocation distance has been established as the key contributor to all forms of impoverishment and this will guide cities to select resettlement sites appropriately and avoid resettlement failure in form of multiple impoverishment. 
Fifth, my study contributes to empirical research on the practice of participatory governance in India and Asian cities. The participatory framework under the $74^{\text {th }}$ Constitutional Amendment Act, 1992 (74 $4^{\text {th }}$ CAA) and Community Participation Law (CPL) is not yet implemented in all States and cities of India. My research forwards evidence of how participatory spaces can be undermined and made ineffective due to the neoliberal bias of the State. Research shows that a policy that clearly identifies proximity, composition, devolution of power, functions and duties of ward committees and area sabhas is needed if States and cities are serious about decentralisation initiatives, otherwise the spaces can become "closed" in local practice.

Along the same lines, the research makes explicit the myth behind the rhetoric of "inclusive planning" and "participatory governance" which were the key objectives behind JNNURM. I quote the Director of Urban Development, Planning Commission, GoI: "The non-negotiable objective of the JNNURM is inclusive growth [...] unless you look at the poor, you cannot make the city compete globally... there was a need for a structure that includes the widest possible participatory process (hence CPL) GoI is clear that there should be no trade-off between growth and equity" (Hindu, 2012). These are some of the many official claims of participatory governance and inclusive growth in urban governance made by GoI. My research forwards evidence of contradictory local practices in a JNNURM funded city and argues that the many awards bestowed by GoI to the city's neoliberal projects contradict the rhetoric.

Sixth, the deviation between the conceptual framework of the study showing ideal relations between citizens, politicians/executives and the judiciary as they would exist in a just social order (Figure 9) and the comprehensive empirical findings (Figure 31) shows how these relations are distorted under neoliberal regimes and lead to socio-spatial disorder and may serve as a reference for cities in India and Asia to evaluate outcomes of their decentralisation initiatives and amend policies accordingly to minimise socio-spatial disorder. Decentralisation is initiated in many countries of Asia, including Philippines, Cambodia, and Vietnam as discussed in chapter 3. For the cities in these countries, this framework and findings may be a useful reference for way forward.

Seventh, the research makes explicit a stealthy nexus between the State of Gujarat and the judiciary on ideals of neoliberal development and socioeconomic rights of the unpropertied citizens leading to a discursive reconstitution of citizenship on a property basis. The research forwards empirical evidence for the United Nations Committee on Economic, Social and Cultural Rights (CESCR), which monitors the implementation of International Covenant on Economic, Social and Cultural Rights (ICESCR) ratified by GoI in 1979, for appropriate action and censure. Future rights-based movements of 
unpropertied citizens are informed about the possible frustration in realisation of the rights at the end of a possibly long struggle.

\subsubsection{Limitations of the study}

Two points of caution are in order with respect to the applicability of these findings in other empirical contexts. First, it is important to note that decentralisation and "actually existing neoliberalism" in Ahmedabad may be unique to its context, as also argued in the literature (Brenner and Theodore, 2002). It may well be possible that in other cities the relations in the conceptual framework may be less conflictual and distorted than in Ahmedabad as the city represents a more aggressive form of neoliberalism than in most cities of India. The transferability of the conceptual framework and empirical findings needs to be explored.

Second, civil society actors including NGOs and civil right activists have remained in the shadows in this research and emerge only occasionally, mainly due to my empirical focus on citizens and their relations with the state and the judiciary, but also due to the realisation that since the neoliberal turn the role of NGOs in issues related to socio-economic rights has been gradually diminishing in the city. However, in other cities NGOs have played a significant role in negotiating right of unpropertied citizens. Patel et al (2012) have shown how an alliance of NGOs (SPARC) with the National Slum Dweller Federation (NSDF) and a community micro-finance association has politically negotiated and resolved in a pro-poor way various socio-economic rights of the poor such as shelter, basic services, livelihood. This has been achieved by the alliance not only in cities of India but also in cities of thirty three other countries through the federated horizontal networks under the aegis of Shack/Slum Dwellers International (SDI).

\subsection{Future research directions and implications for governance}

Three research directions open up from this research:

The first direction is in how far decentralisation will hold in urban governance in neoliberalising Indian cities. The conceptual framework forwarded by my research can provide a useful hypothesis in the empirical context of other cities of India. Cities of India are in different stages of implementing $74^{\text {th }}$ CAA and CPL (for cities which were covered under JNNURM). Related to research on the future of decentralization in urban governance are questions concerning if and how State and local government policies under $74^{\text {th }}$ CAA and CPL are deployed to ensure effective participatory spaces that allow marginalized citizens to effectively negotiate their rights. 
The second direction is the stance of the high courts of other Indian States in the claim making process of marginalized citizens and in opening "çlosed" participatory spaces. The questions will be in how far is the judiciary sympathetic to economic rights of unpropertied citizens and whether this has led to realisation of their rights and opening spaces for negotiation in local governance.

The third direction leads to the role of federated horizontal networks, such as Shack/Slum Dwellers International, in reclaiming rights of unpropertied citizens. While scholars have discussed the role of a global federation of horizontal networks and its ability to co-produce information with the state and negotiate rights, more research on such networks and the conditions that make them successful is required. 


\section{Bibliography}

ACKERMAN, J.M. \& SANDOVAL-BALLESTEROS, I.E. 2006. The Global Explosion of Freedom of Information Laws. Administrative Law Review, 58, 85130.

ADMINISTRATIVE STAFF COLLEGE INDIA 2011. Module 1 - Urban Governance. Jawaharlal Nehru National Urban Renewal Mission (JnNURM) Regional Capacity Building Hub. Hyderabad.

AGARWAL, N. 2016. Unleashing the full potential of India's 'Open Government Data' initiative Ideas for India for evidence-based policy [Online].

AHMEDABAD MIRROR BUREAU. 2011 Sabarmati Riverfront kids shifted to Piplaj dropping out of school. Ahmedabad Mirror, December 24.

AHMEDABAD MUNICIPAL CORPORATION 2007. City Development Plan for Ahmedabad (2006-2012). New Delhi: Ministry of Urban Development.

AHMEDABAD MUNICIPAL CORPORATION 2012. Budget 2012-13. Ahmedabad: Ahmedabad Municipal Corporation.

AHMEDABAD MUNICIPAL CORPORATION 2013. Budget 2013-14. Ahmedabad: Ahmedabad Municipal Corporation.

AHMEDABAD MUNICIPAL CORPORATION 2014. Budget 2014-15. 23/01/2014 ed. Ahmedabad: Ahmedabad Municipal Corporation.

ALICIAS, M.D. 2011. Decentralisation and Local Participatory Development : Experiences from Cambodia. South to South Forum on Sustainability. Lingnan University, Hong Kong.

APPADURAI, A. 2000. Grassroots Globalization and the Research Imagination. Public Culture, 12, 1-19.

APPADURAI, A. 2001. Deep democracy: urban governmentality and the horizon of politics Environment and Urbanization, 13, 23-43.

APPADURAI, A. \& HOLSTON, J. 1996. Cities and Citizenship. Public Culture, 8, 187-204.

ASSOCHAM 2012. Investment and Growth Patterns across 20 major Indian states. In: INDIA, A. C. O. C. A. I. O. (ed.). New Delhi.

AVILA, R., FEIGENBLATT, H., HEACOCK, R. \& HELLER, N. 2010. Global mapping of technology for transparency and accountability. London: Open Society Foundation.

BARTOLOME, L., DEWET, C. \& MANDER, H. 1999. Displacement, Resettlement, Rehabilitation, Reparation and Development. Cape Town: World Commission on Dams.

BAUD, I. \& DEWIT, J. 2009. Shifts in Urban Governance : Raising the Questions. In: BAUD, I. \& DEWIT, J. (eds.) New Forms of Urban Governance in India : Shifts, Models, Networks and Contestations. New Delhi: Sage Publications India.

BAUD, I. \& NAINAN, N. 2008. "Negotiated spaces" for representation in Mumbai : ward committees, advanced locality management and the 
politics of middle-class activism Environment and Urbanization 20, 483-499.

BAVISKAR, A. 2003. Between Violence and Desire: Space, Power and Identity in the Making of Metropolitan Delhi. International Social Science Journal, 55, 80-98.

BAVISKAR, A. 2010. Winning the Right to Information in India: Is Knowledge Power? . In: GAVENTA, J. \& MCGEE, R. (eds.) Citizen Action and National Policy Reform: Making Change Happen. London: Zed Books.

BENJAMIN, S., BHUVANESWARI, R. \& RAJAN, P. 2007. Bhoomi:'Egovernance', or, an anti-politics machine necessary to globalize Bangalore? CASUM-m Working Paper.

BETTENHAUSEN, K. \& MURNIGHAN, K. 1986. The emergence of norms in competitive decision-making groups. Admin istrative Science Quarterly, 30, 350-372.

BHAGWATI, J. \& PANAGARIYA, A. 2012. India's Tryst with Destiny: Debunking Myths that Undermine Progress and Addressing New Challenges, New Delhi, Collins Business.

BHAN, G. 2009. "This is no longer the city I once knew". Evictions, the urban poor and the right to the city in millennial Delhi. Environment and Urbanization Vol 21, 127-142.

BHAN, G., GOSWAMI, A. \& REVI, A. 2014. The intent to Reside : Spatial illegality, Inclusive Planning, and Urban Social Security. Inclusive Urban Planning : State of the Urban Poor Report 2013. New Delhi: Oxford University press.

BOVENS, M. 2002. Information rights: citizenship in the information society. Journal of Political Philosophy, 10, 317-341.

BOVENS, M. 2005. Public Accountability, Oxford, Oxford University Press.

BOVENS, M. 2007. Analysing and Assessing Accountability: A Conceptual Framework European Law Journal, 13, 447-468.

BRENNER, N. \& THEODORE, N. 2002. Cities and the Geographies of "Actually Existing Neoliberalism". Antipode, 34, 349-379.

BRODIE, J. 2000. Imagining democratic urban citizenship. In: BRODIE, J. (ed.) Democracy, citizenship and the global city. New York: Routledge.

CERNEA, M. 2000a. Impoverishment or Social Justice? A Model for Planning Resettlement. In: MATHUR, H. M. \& MARSDEN, D. (eds.) Development Projects and Impoverishment Risks: Resettling Project-Affected People in India. Oxford University Press.

CERNEA, M. 2000b. Risks, Safeguards and Reconstruction: A model for Population Displacement and Resettlement. In: CERNEA, M. \& C.MCDOWELL (eds.) Risks and Reconstruction: Experiences of Resettlers and Refugees. Washington DC: The World Bank.

CHARMAZ, K. (ed.) 2006. Constructing Grounded Theory : A practical Guide Through Qualitative Analysis, London: Sage. 
CHATTERJEE, I. 2014. Displacement, Revolution and the New Urban Condition : Theories and Case Studies, New Delhi, Sage Publications India Pvt.Ltd.

CHATTERJEE, P. 2004. The Politics of the Governed: Reflections on Popular Politics in Most of the World, New York, Columbia University Press.

CHILTON, P. \& SCHÄFFNER, C. 2002. Politics as text and talk: Analytic approaches to political discourse, Amsterdam / Philadelphia, John Benjamins Publishing.

COELHO, K., KAMATH, L. \& M.VIJAYBASKAR 2011. Infrastructures of Consent: Interrogating Citizen Participation Mandates in Indian Urban Governance. Brighton Institute of Development Studies.

COELHO, V.S. \& FAVARETO, A. 2011. Participatory Governance and Development: In Search of a Causal Nexus. Geography Compass, 5, 641-654.

CONCERNED CITIZENS OF AHMEDABAD 2010. Our Inclusive Ahmedabad: Report of Public Hearing on Habitat and Livelihood Displacements. Ahmedabad.

CORNWALL, A. \& COELHO, V.S. 2007. Spaces for Change?: The Politics of Citizen Participation in New Democratic Arenas. London and New York: Zed Books.

CORNWALL, A. \& GAVENTA, J. 2001. From users and choosers to makers and shapers : Repositioning participation in social policy. IDS Working Paper. Brighton: Institute of Development Studies.

CROOK, R. \& MANOR, J. 1998. Democracy and Decentralisation in South Asia and West Africa : Participation, Accountability and Performance, Cambridge, Cambridge University Press.

CROOK, R. \& SVERRISSON, A. 2003a. Decentralisation and Poverty Alleviation in Developing Counties : A Comparative analysis or is West Bengal unique?'. IDS Working Paper. Brighton, Sussex: Institute of Development Studies.

CROOK, R. \& SVERRISSON, A.S. 2003b. Does Decentralisation Contribute to Poverty Reduction? Surveying the Evidence. In: HOUTZAGER, P. P. \& M.MOORE (eds.) Changing Path : International Development and the New Politics of Inclusion. Ann Arbor: University of Michigan Press.

CURTIN, D. \& MEIJER, A.J. 2006. Does transparency strengthen legitimacy? A critical analysis of European Union policy documents. Information Polity, 11, 109-122.

D'MONTE, D. 2015. Ahmedabad: Two steps forward, one step back. Rediff.com, 16th June 2015.

DAVE, D. June 21, 2012 The dirty picture. Ahmedabad Mirror.

DE VRIES, W. \& LANCE, K. 2011. SDI Reality in Uganda: Coordinating between Redundancy and Efficiency. In: NEDOVIĆ-BUDIĆ, J, C., YOLA, G. \& RATON, B. (eds.) Spatial Data Infrastructures in Context - North and South. London, New York, : CRC Press. 
DEBROY, B. 2012. Gujarat : Governance for Growth and Development, New Delhi, Academic Foundation.

DELOITTEE.TOUCHE.TOHMATSU.INDIA.PVT.LTD 2013. JNNURM Reform Appraisal Report. In: MINISTRY OF URBAN DEVELOPMENT (MOUD), G. O. I. (ed.). New Delhi.

DESAI, R. 2006. Uneasy Negotiations: Urban Redevelopment, Neoliberalism and Hindu Nationalist Politics in Ahmedabad, India. Breslauer Graduate Student Symposium, University of California International and Area Studies. Berkeley.

DESAI, R. 2012a. Entrepreneurial Urbanism in the Time of Hindutva: City Imagineering, Place Marketing and Citizenship in Ahmedabad In: DESAI, R. \& SANYAL, R. (eds.) Urbanizing Citizenship: Contested Spaces in Indian Cities. New Delhi: Sage.

DESAI, R. 2012b. Governing the Urban Poor: Riverfront Development,Slum Resettlement and the Politics of Inclusion in Ahmedabad. Economic \& Political Weekly 47, 49-56.

DESAI, R. 2014. Municipal Politics, Court Sympathy and Housing Rights: A Post-Mortem of Displacement and Resettlement under the Sabarmati Riverfront Project, Ahmedabad. CUE Working Paper. Ahmedabad: Centre for urban Equity,CEPT University.

DESHPANDE, S. 2006. Mapping the 'middle': issues in the analysis of the 'nonpoor' classes in India In: M.E.JOHN, JHA, P. K. \& S.S.JODHKA (eds.) Contested transformations: changing economies and identities in contemporary India. New Delhi Tulika Books.

DEVARHUBLI, C. September 2nd, 2013. 200\% rise in BPL families in state in 13 yrs. DNA.

DEVAS, N. 2004. Urban Governance, Voice, and Poverty in the Developing World, London, Earthscan.

DEWET, C. 2006 Risk, Complexity and Local Initiative in Forced Resettlement Outcomes. In: DEWET, C. (ed.) Development-induced displacement: problems, policies, and people. Oxford: Berghahn Books.

DEWIT, J., NAINAN, N. \& PALNITKAR, S. 2008. Urban Decentralisation in Indian Cities : Assessing the Performance of Neighbourhood Level Ward Committees. In: BAUD, I. \& DEWIT, J. (eds.) New Forms of Urban Governance in India : Shifts, Models, Networks and Contestations. New Delhi: Sage Publications India.

DNA. June 2nd, 2012 AMC to hand over BPL cards to 2.22 lakh families. DNA.

DNA AGENCY. 2011. Evicted slum-dwellers in Ahmedabad turn violent. Daily News \& Analysis (DNA), May 11, 2011.

DOWNING, T.E. 1996. Mitigating Social Impoverishment when People are Involuntarily Displaced. In: MCDOWELL, C. (ed.) Understanding Impoverishment Providence. Oxford: Berghahn Books.

DUPONT, V. 2008. Slum Demolitions in Delhi since the 1990s :an appraisal. Economic \& Political Weekly, 43, 79-87. 
DUPONT, V. 2011. The Dream of Delhi as a Global City. International Journal of Urban and Regional Research, 35, 533-554.

DUPONT, V. \& RAMANATHAN, U. 2008. The Courts and the squatter Settlements in Delhi- Or the intervention of the Judiciary in Urban 'Governance'. In: BAUD, I. \& DEWIT, J. (eds.) New Forms of Urban Governance in India : Shifts, Models, Networks and Contestations. New Delhi: Sage Publications India.

DUTTA, S. 2000. Partnerships in urban development: a review of Ahmedabad's experience Environment and Urbanization 12, 13-26.

EATON, K. 2001. Political Obstacles to Decentralisation : Evidence from Argentina and the Phillipines. Development and Change, 32, 101-27.

EISENHARDT, K. 1989. Building Theories from Case Study Research. The Academy of Management Review, 14, 532-550.

EPC 1998. Proposal for the Sabarmati Riverfron Development : Report prepared for SRDC, Ahmedabad.

FENSTER, M. 2006. The Opacity of Transparency. Iowa Law Review, 91, 885949.

FENSTER, M. 2012. The Transparency Fix: Advocating Legal Rights and Their Alternatives in the Pursuit of a Visible State http://ssrn.com/abstract $=1918154$.

FERNANDES, L. 2004. The Politics of Forgetting: Class Politics, State Power and the Restructuring of Urban Space in India. Urban Studies, 41, 24152430.

FERNANDES, W. 1991. Power and Powerlessness: Development Projects and Displacement of Tribals. Social Action, 41, 243-270.

FUNG, A., GILMAN, H. R. \& SHKABATUR, J. 2010. Impact case studies from middle income and developing countries. London, UK: Transparency and Accountability Initiative.[online]. Available from: http://www.transparency-initiative.org/wpcontent/uploads/2011/05/impact_case_studies_final1. pdf.

FUNG, A., GRAHAM, M. \& WEIL, D. 2007. Full disclosure: The perils and promise of transparency, Cambridge University Press.

FUNG, A. \& WRIGHT, E. O. 2003a. Deepening Democracy : Institutional Innovations in empowered participatory Governance, London, New York, Verso.

FUNG, A. \& WRIGHT, E. O. 2003b. Thinking about Empowered Participatory Governance In: FUNG, A. \& WRIGHT, E. O. (eds.) Deepening Democracy : Institutional Innovations in Empowered Participatory Governance

London, New York: Verso.

GAVENTA, J. 2006. Finding the Spaces for Change: A Power Analysis. IDS Bulletin Volume, 37, 23-33.

GAVISON, R. 2003. On the relationships between civil and political rights, and social and economic rights. The globalization of human rights, 23-55. 
GEORGE, S. \& NAUTIYAL, S. (eds.) 2006 Eviction Watch India-II, New Delhi: Human Rights Law Network.

GEORGIADOU, Y., LUNGO, J. H. \& RICHTER, C. 2014. Citizen sensors or extreme publics? Transparency and accountability interventions on the mobile geoweb. International Journal of Digital Earth, 7, 516-533.

GHERTNER, A. 2008. Analysis of New Legal Discourse behind Delhi's Slum Demolitions. Economic and Politcal Weekly, 43, 57-66.

GHERTNER, A. 2011. Gentrifying the State, Gentrifying Participation: Elite Governance Programs in Delhi. International Journal of Urban and Regional Research, 35, 504-532

GHOSH, A. \& MITRA, M. 2008. Institutionalising People's Participation in Urban Governance: An inter-city Perspective of Wards Committees in West Bengal. In: BAUD, I. \& DEWIT, J. (eds.) New Forms of Urban Governance in India. New Delhi: Sage Publications India.

GLASER, B. \& STRAUSS, A. 1967. The discovery of grounded theory: Strategies of qualitative research, London, Wiedenfeld and Nicholson.

GOODWIN, M. \& PAINTER, J. 1996. Local governance, the crises of Fordism and the changing geographies of regulation. Transactions of the Institute of British Geographers, 21, 635-648.

GOVERNMENT OF GUJARAT 1973. Gujarat Slum Areas (Improvement, Clearance and Redevelopment) Act, 1973. Gandhinagar.

GOVERNMENT OF GUJARAT 2003. Industrial Policy Statement. In: INDUSTRIES, D. O. (ed.). Gandhinagar.

GOVERNMENT OF GUJARAT 2007. Gujarat Municipal Corpration's Wards Committees Functions, Duties, Territorial Areas and procedure for Transaction of Business Rules. In: U.D.U.H.D (ed.). Gandhinagar.

GOVERNMENT OF GUJARAT 2009. Industrial Policy Statement. In: INDUSTRIES, D. O. (ed.). Gandhinagar.

GOVERNMENT OF GUJARAT 2012. Functions, Duties, Territorial Areas and procedure for Transaction of Business of Area Sabhas Rules: Resolution No. MIS/102012/533/P. In: U.D.U.H.D (ed.). Gandhinagar.

GOVERNMENT OF INDIA 1992. The Constitution Seventy Fourth Amendment Act 1992 on Municipalities. In: (MOUD), M. O. U. D. (ed.). New Delhi.

GOVERNMENT OF INDIA, M. L. J. 2005. Right to Information Act. In: JUSTICE, M. O. L. A. (ed.). New Delhi: Government of India.

GOVERNMENT OF INDIA, M. O. H. A. U. P. A. 2009a. Jawaharlal Nehru National Urban Renewal Mission, Basic Services to Urban Poor- Checklist for preparation / appraisal of DPR for BSUP. In: ALLEVIATION, M. O. H. A. U. P. (ed.). New Delhi.

GOVERNMENT OF INDIA, M. O. H. A. U. P. A. 2009b. Jawaharlal Nehru National Urban Renewal Mission, Revised guidelines BSUP. In: ALLEVIATION, M. O. H. A. U. P. (ed.). New Delhi. 
GOVERNMENT OF INDIA, M. O. U. D. 2006a. Jawaharlal Nehru national Urban Renewal Mission : Momorandum of Agreement of Ahmedabad. In: MINISTRY OF URBAN DEVELOPMENT (ed.). New Delhi.

GOVERNMENT OF INDIA, M. O. U. D. 2006b. Jawaharlal Nehru national Urban Renewal Mission : Momorandum of Agreement of Ahmedabad, State Reform Checklist Community Participation Law. In: MINISTRY OF URBAN DEVELOPMENT (ed.). New Delhi.

GOVERNMENT OF INDIA, M. O. U. D. 2006c. Jawaharlal Nehru national Urban Renewal Mission : Momorandum of Agreement of Ahmedabad, State Reform Checklist, Public Disclosure Law. In: DEVELOPMENT, M. O. U. (ed.). New Delhi.

GOVERNMENT OF INDIA, M. O. U. D. 2006d. Jawaharlal Nehru National Urban Renewal Mission Primers : Community Participation Law, State Level Reform. In: MINISTRY OF URBAN DEVELOPMENT (ed.). New Delhi.

GOVERNMENT OF INDIA, M. O. U. D. 2006e. Jawaharlal Nehru National Urban Renewal Mission Primers : Public Disclosure Law, State Level Reform. In: MINISTRY OF URBAN DEVELOPMENT (ed.). New Delhi.

GOVERNMENT OF INDIA, M. O. U. D. 2009c. Jawaharlal Nehru National Urban Renewal Mission, Urban Infrastructure and Governance - Overview. In: MINISTRY OF URBAN DEVELOPMENT (ed.). New Delhi

GOVERNMENT OF INDIA, M. O. U. D. 2015. Smart Cities Mission : SPVs. In: MINISTRY OF URBAN DEVELOPMENT (ed.). New Delhi.

GOVERNMENT OF INDIA, M. S. T. 2012. National Data Sharing and Accessibility Policy. In: TECHNOLOGY, M. O. S. A. (ed.). New Delhi: Department of Science and Technology.

GRANT THORNTON 2011. Appraisal of Jawaharlal Nehru National Urban Renewal Mission (JnNURM) Final Report - Volume I. In: MINISTRY OF URBAN DEVELOPMENT (MOUD), G. O. I. (ed.). New Delhi: Grant Thornton India.

GRIFFIN, J. 1986. Well-Being: Its Meaning, Measurement, and Moral Importance. London: Clarendon Press.

GUBA, E. \& LINCOLN, Y. 1994. Competing Paradigms in Qualitative Research. In: DENZIN, N. \& LINCOLN, Y. (eds.) Handbook of Qualitative Research. Thousand Oaks London New Delhi: Sage Publications.

GUPTA, A. 2006. Blurred Boundaries: The Discourse of Corruption, the Culture of Politics, and the Imagined State. In: A, S., A, G. \& MALDEN (eds.) The anthropology of the state. Oxford, Carlton: Blackwell Publishing.

GURSTEIN, M.B. 2011. Are the Open Data Warriors Fighting for Robin Hood or the Sheriff? Some Reflections on OkCon2011 and the Emerging Data Divide. posting to the nettime mailing list, July, 5.

HANNERZ, U. 2003. Being there... and there..and there...! : Ewflwction on MultiSite Ethnography. Ethnography, 4, 201-216. 
HARVEY, D. 1989. From Managerialism to Entrepreneurialism: The Transformation in Urban Governance in Late Capitalism. Human Geography, 71, 3-17.

HARVEY, D. 2003. The right to the city. International Journal of Urban and Regional Research, 27, 939-941.

HAUSSERMANN, H., LAPPLE, D. \& SIEBEL, W. 2008. Stadtpolitik, Frankfurt Suhrkamp.

HAY, C. \& JESSOP, B. 1995. Introduction: local political economy, regulation and governance. Economy and Society, 24, 303-306.

HEALD, D. 2006. Varieties of transparency, Oxford University Press for The British Academy.

HENSMAN, R. 2014. The Gujarat Model of Development. What would it do to the Indian Economy? Economic and Political Weekly, XLIX, Web exclusive article available at: http://www.epw.in/reportsstates/gujarat-model- development.html

HIRWAY, I., SHAH, A. \& SHAH, G. 2014. Growth and Development in Gujarat : An Introduction. In: HIRWAY, I., SHAH, A. \& SHAH, G. (eds.) Growth or Development : Which way is Gujarat Going? New Delhi: Oxford University Press.

HOOD, C. 2006. Transparency in historical perspective, Oxford University Press.

HRLN 2006. Eviction Watch India-II. In: GEORGE, S. \& NAUTIYAL, S. (eds.). New Delhi: Human Rights Law Network.

JAMES, H. 2011. Demolition takes toll on 'legal' houses. Ahmedabad Mirror, November 21.

JANSSEN, K. 2012. Open Government Data and the Right to Information: Opportunities and Obstacles. The Journal of Community Informatics 8.

JONES, M. 1999. New institutional spaces: training and enterprise councils and the remaking of economic governance, London, Jessica Kingsley.

KANNAN, K. P. 2015. Interrogating Inclusive Growth: Poverty and Inequality in India, New Delhi, Routledge.

KOHLI, A. 2006. Politics of Economic Growth in India, 1980-2005. Economic and Political Weekly 1251-1259.

KUNDU, D. 2011. Elite Capture in Participatory Urban Governance. Economic \& Political Weekly, XLVI, 23-25.

LIVENGOOD, A. \& KUNTE, K. 2012. Enabling participatory planning with GIS: a case study of settlement mapping in Cuttack, India. Environment \& Urbanization, 24 77-97.

MAHADEVIA, D. 2002. Communal Space over Life Space: Saga of Increasing Vulnerability in Ahmedabad. Economic and Political Weekly, 37, 48504858.

MAHADEVIA, D. 2011. Branded and Renewed? Policies, Politics and Processes of Urban Development in the Reform Era. Economic \& Political Weekly, $46,56-64$. 
MAHADEVIA, D. 2014. Institutionalising Spaces for Negotiations for the Urban Poor: New Vocabulary for Urban Planning. Inclusive Urban Planning : State of the Urban Poor Report 2013. New Delhi: Oxford University Press.

MAHADEVIA, D., DATEY, A. \& MISHRA, A. 2013. Foisting Mass Housing on the Poor: Lessons from Social Audit of BSUP. October 2013 ed. Ahmedabad: Centre for Urban Equity, CEPT University.

MARCUSE, P. 2009. From critical urban theory to the right to the city. City, 13.

MARCUSE, P. \& VAN KEMPEN 2000. Globalized cities: a new spatial order?, Oxford, Blackwell.

MARSHALL, T. H. 1950. Citizenship and Social Class. In: MANZA, J. \& SAUDER, M. (eds.) Inequality and Society. New York: Norton and Co.

MATHUR, H.M. 1998. Impoverishment Risk Model and its Use as a Planning Tool. In: MATHUR, H. M. \& MARSDEN, D. (eds.) Development Projects and Impoverishment Risks: Resettlement Project-Affected People in India. New Delhi: Oxford University Press.

MATTNER, M. 2004. Power to the people?Local governance and politics in Vietnam. Environment \& Urbanization 16 121-128.

MCCLUSKEY, M. 2003. Efficiency and social citizenship: challenging the neoliberal attack on the welfare state. Indiana Law Journal 78

MEIJER, A. 2009. Understanding modern transparency. International Review of Administrative Sciences, 75, 255-269.

MEIJER, A.J., CURTIN, D. \& HILLEBRANDT, M. 2012. Open government: connecting vision and voice. International Review of Administrative Sciences, 78, 10-29.

MEMORANDUM OFFICE OF MANAGEMENT AND BUDGET 2009. Open Government Directive. http://www.whitehouse.gov/sites/default/files/omb/assets/memoran da 2010/m10-06.pdf.

MENON-SEN, K. \& BHAN, G. 2008. Swept off the Map : Surviving eviction and Resettlement in Delhi, New Delhi, YODA Press.

MHUPA 2014. Jawaharlal Nehru National Urban Renewal Mission : Monitoring Formats.

NAINAN, N. \& BAUD, I. 2008. Negotiating for Participation : Decentralisation and NGOs in Mumbai, India. In: BAUD, I. \& DEWIT, J. (eds.) New Forms of Urban Governance in India : Shifts, Models, Networks and Contestations. New Delhi: Sage Publications India.

NAYUDU, U. 2009. Slum rehabilitation: AMC settles for 1976 as cut-off date. Indian Express, Aug 302009.

NIGAM, S. 2013. Gujarat and the Illusion of Development". Kafila.org, http://kafila.org/2013/05/23/gujarat-and-the-illusion-ofdevelopment-shipra-nigam/, accessed on 8 March, 2014 .

ONG, A. 2006. Neoliberalism as Exception, Durham, North Carolina, Duke University Press. 
PAINTER, J. 1995. Regulation theory, post-Fordism, and urban politics. In: JUDGE, D. \& STOKER, G. (eds.) Theories of urban politics. Thousand Oaks: Sage.

PANDEY, P. 2013. Encounter killings of RTI activists.....Gujarat tops charts. The Times of India.

PARRY, G., MOYSER, G. \& DAY, N. 1992. Political Participation and Democracy in Britain, Cambridge, Cambridge University Press.

PAS 2013. Performance Benchmark of Urban Water Supply \& Sanitation in Gujarat Data Book ( 2009-13) : City Profiles (Municipal Corporations). Ahmedabad: CEPT University.

PATEL, S. 2013. Upgrade, rehouse or resettle? An assessment of the Indian government's Basic Services for the Urban Poor (BSUP) programme. Environment and Urbanization, Vol 25 1-12.

PATEL, S., BAPTIST, C. \& D'CRUZ, C. 2012. Knowledge is power - informal communities assert their right to the city through SDI and communityled enumerations. Environment \& Urbanization 24, 13-26.

PATEL, S., D'CRUZ, C. \& BURRA, S. 2002. Beyond evictions in a global city: people-managed resettlement in Mumbai. Environment and Urbanization 14, 159-172.

PATEL, S. \& MANDHYAN, R. 2014. Impoverishment assessment of slum dwellers after off-site and on-site resettlement: a case of Indore. Commonwealth Journal of Local Governance, 15, 104-127.

PATEL, S., SLIUZAS, R. \& GEORGIADOU, Y. 2016. Participatory local governance in Asian cities: invited, closed or claimed spaces for urban poor? . Environment \& Urbanization Asia, 7, 1-21.

PATEL, S., SLIUZAS, R. \& MATHUR, N. 2015. The risk of impoverishment in urban development-induced displacement and resettlement in Ahmedabad. Environment and Urbanization, 27, 231-256.

PAYNE, T. \& SKELCHER, C. 1997. Explaining less accountability: The growth of local quangos. Public Administration, 75, 207-224.

PIERRE, J. \& PETERS, B. G. 2000. Governance, Politics and the State, New York, St. Martin's Press.

PLANT, R. 1992. Citizenship, Rights and Welfare In: COOTE, A. (ed.) The Welfare of Citizens: developing new social rights. London: IPPR/Rivers Oram Pres.

PURCELL, M. 2002. Excavating Lefebvre: The right to the city and its urban politics of the inhabitant. GeoJournal 58, 99-108.

PURCELL, M. 2003. Citizenship and the right to the global city: reimagining the capitalist world order. International Journal of Urban and Regional Research, 27, 564-590.

RAJAGOPAL, B. 2007. Pro-Human Rights but Anti-Poor? A critical Evaluation of the Indian Supreme Court from a Social Movement Perspective. Human Rights Review, 8. 
RAMAN, B. 2012. The Rhetoric and Reality of Transparency: Transparent Information, Opaque City Spaces and the Empowerment Question. The Journal of Community Informatics, 8.

RAMAN, B. \& BAWA, Z. 2011. Interacting with the State via Information and Communication Technologies: The Case of Nemmadi Kendras in Karnataka. Media Asia, 38, 52-64.

RAMANATHAN, U. 2005. Demolition drive. Economic and Political Weekly, 40, 2908-2912.

RAMANATHAN, U. 2006. Illegality and the Urban Poor. Economic and Political Weekly 41, 3193-3198.

RAWLS, J. 2009. A theory of justice, Harvard, Harvard University Press.

REGISTRAR GENERAL \& CENSUS COMMISSIONER 2011. Primary Census Abstract. In: INDIA, G. O. (ed.). New Delhi.

RICHTER, C. 2011. In-Tensions to Infrastructure Developing Digital Property Databases in Urban Karnataka, India. Environment and Urbanization Asia, 2, 205-222.

ROBERTS, A. 2010. A great and revolutionary law? The first four years of India's Right to Information Act. Public Administration Review, 70, 925-933.

ROSE, N. 1999. Powers of Freedom: Reframing Political Thought, Cambridge, Cambridge University Press.

SANDHU, R. S. \& SANDHU, J. 2007. Globalizing cities: inequality and segregation in developing countries, Jaipur, Rawat.

SASSEN, S. 1991. The global city: New York, London, Tokyo., Princeton, NJ, Princeton University Press.

SERAGELDIN, I. 2006. Involuntary Resettlement in World Bank Financed Projects : Reducing Impoverishment Risks for the Affected People. In: MATHUR, H. M. (ed.) Managing Resettlement in India : Approaches, Issues, Experiences. New Delhi: Oxford University Press.

SHAH, G. 2014. Governance of Gujarat : Good Governance for Whom and for What? In: HIRWAY, I., SHAH, A. \& SHAH, G. (eds.) Gowth of Development : Which way is Gujarat Going? New Delhi: Oxford University Press.

SHAH, K. 2013. The Sabarmati Riverfront Development Project: Great. But Much Needs to Change. Daily News and Analysis, 10 June, 2013.

SHKABATUR, J. 2012. Transparency with (out) accountability: Open government in the United States. Yale Law \& Policy Review, 31, 79140.

SIDDIQUI, T. 2009. Former mayor alleges bias in functioning of ward committees. Indian Express, Mon Aug 31.

SINGH, B. N. \& MAITRA, S. (eds.) 2001. Formation of Ward Committees in Urban Governance at grassroots Level, New Delhi: Government of India-UN-Habitat. 
SIVARAMAKRISHNAN, K.C. 2000. Power to the People? The Politics and Progress of Decentralisation, New Delhi, Konark Publishers Pvt. Ltd.

SLEE, T. 2012. Seeing like a geek. Crooked Timber, 25.

SMITH, N. 2002. New Globalism, New Urbanism: Gentrification as Global Urban Strategy. Antipode, 43, 427-450.

SRIDHARAN, N. 2008. New Forms of Contestation and Cooperation in Indian urban Governance. In: BAUD, I. \& DEWIT, J. (eds.) New Forms of Urban Governance in India : Shifts, Models, Networks and Contestations. New Delhi: Sage Publications India.

STALDER, F. 2011. The fight over transparency: From a hierarchical to a horizontal organization. Rotterdam: Open, NAI.

STARR, P. 2010. The liberal state in a digital world. Governance, 23, 1-6.

SWYNGEDOUW, E. 2005. Governance Innovation and the Citizen: The Janus Face of Governance-beyond-the-State. Urban Studies, 42.

TEEFFELEN, J.V. \& BAUD, I. 2011. Exercising Citizenship: Invited and Negotiated Spaces in Grievance Redressal Systems in Hubli-Dharwad Environment and Urbanization Asia, 2, 169-185.

TERI 2010. Enhancing public participation through effective functioning of Area Sabhas. New Delhi: TERI.

TOI 2011. Ahmedabad best city to live in, Pune close second. The Times of India. Ahmedabad.

TRIPATHI, D. 1998. Alliance for Change : A Slum Upgrading Experiment in Ahmedabad, New Delhi, Tata McGraw-Hill.

TURNER, M. \& HULME, D. 1997. Decentralization within the State: Good Theory but Poor Practice? In: TURNER, M. \& HULME, M. (eds.) Governance, Administration and Development. UK: Macmillan Education.

UN 2015. Statement : Secretary-General's remarks at 'Vibrant Gujarat' Summit. In: AGFE, U. (ed.). Gandhinagar, India, 11 January 2015

UN CESCR. 2008. Concluding Observations of the UN Committee on Economic, Social and Cultural Rights, Fortieth Session, [Online]. [Accessed].

UNHABITAT 2003. The challenge of slums, London, UNHABITAT.

WGHR 2012. Human Rights in India : Status Report 2012. Universal Periodic Review at the UN. New Delhi.

WORLD BANK 2000. Entering the 21st Century, World Development Report 1999/2000 Oxford, Oxford University Press.

WORLD BANK 2015. Speeches \& Transcripts : India's Program for Inclusive and Sustainable Growth in the 21st Century. Vibrant Gujarat Summit, Gandhinagar, India.

YILMAZ, S. \& VENUGOPAL, V. 2013. Local Government Discretion And Accountability In Philippines. Journal of International Development, 25, 227-250.

YIN, R. 1984. Case study research, Beverly Hills, CA, Sage Publications.

YU, H. \& ROBINSON, D. 2012. The new ambiguity of'open government'. Princeton CITP. Yale ISP Working Paper. 


\section{Summary}

In the past decade, neoliberal Ahmedabad has become a role model for other cities in India, and across the globe, as awards have been pouring in the city for many of its urban development projects. This research is empirically grounded in the city of Ahmedabad and the Indian State of Gujarat. It reflects critically on tensions between neoliberalisation and decentralization reforms and their consequences for the rights of un-propertied citizens and a city's social-spatial order. The research findings are:

First, while decentralisation reforms mandate participatory spaces in local governance, in practice such spaces are deemed inefficient and inappropriate for efficient service delivery and urban development by the State and local government. The neoliberal bias of local government closes the "invited" spaces, instituted through decentralization, with negative implications on the ability of un-propertied slum dwellers to negotiate their socio-economic rights. The neoliberal State (in policy) and local government (in practice) are able to maintain the closed spaces with the backing of the judiciary.

Second, the propertied middle class is emerging as an influential and favoured electorate. Though decentralisation opens up opportunities for un-propertied citizens to negotiate their needs via elected representatives through clientelism, the latter are more responsive to the needs and aspirations of the middle class at the cost of un-propertied slum dwellers. This deprives the poor of political voice despite the new political rights promised by decentralisation.

Third, neoliberal city projects are implemented by semi-autonomous governing bodies wherein decisions are made by actors who are not directly accountable to the local electorate and subject to democratic control. Information on urban development projects is not disclosed under the Right to Information Act to the public, and especially to the "project-affected community". Although decentralisation has a sympathetic ring for political legitimacy, it has in fact become a vehicle by the neoliberal local and State government to confer favours to elite citizens and semi-autonomous bodies under arrangements that are undemocratic, opaque and fuzzy.

Fourth, middle class citizens are collectively filing petitions for eviction of slums to the high courts in their States, framing slums as "nuisance" under environmental laws of India, "unaesthetic", a hindrance to the realisation of a "world-class image" for their cities and a detriment to their property values. High courts are often biased towards the middle class, deny shelter rights to the poor, and contribute to further capital accumulation by the middle class. Thus, substantive citizenship is reconstituted discursively and materially on the basis of property. Un-propertied citizens are reconstituted as "subgrade", with less political and socio-economic rights than the propertied and are subjected 
to uncertainty, a new form of impoverishment, due to lack of information regarding the eviction and resettlement process. The research argues that the information opacity of local government towards un-propertied citizens may be countered by horizontal information transparency initiatives, currently pursued by Slum Dwellers International, which enable social relations of mutuality and trust in global and local networks of slum dwellers. 


\section{Samenvatting}

In de afgelopen tien jaar is het neoliberale Ahmedabad een voorbeeld geworden voor andere steden in India en over de hele wereld, nadat de stad is overstelpt met prijzen voor verschillende stedelijke ontwikkelingsprojecten. Dit empirische onderzoek is geaard en uitgevoerd in de stad Ahmedabad en de Indiase staat Gujarat. Het biedt een kritische beschouwing over het spanningsveld tussen neoliberalisme en hervormingen op het gebied van decentralisatie, de gevolgen daarvan voor de rechten van bezitloos sloppenbewoners en de sociaal-ruimtelijke planning van een stad. De bevindingen van het onderzoek zijn:

Ten eerste decentralisatie maakt participatie aan de lokale overheid wel mogelijk, maar in de praktijk worden deze mogelijkheden ervaren als inefficiënt en ongeschikt om efficiënte service en stedelijke ontwikkeling door de staat en de lokale overheid te bewerkstelligen. De neoliberale inslag van de lokale overheid sluit de deur voor de geboden mogelijkheden die door decentralisatie worden gecreëerd. Dit heeft negatieve implicaties voor de kansen van sloppenbewoners om over hun sociaal-economische rechten te onderhandelen. De neoliberale staat (in beleid) en de lokale overheid (in praktijk) kunnen de mogelijkheden gesloten houden omdat ze worden gesteund door het rechtssysteem.

Ten tweede komen de huizenbezitters uit de middenklasse op als invloedrijk en begunstigd electoraat. Hoewel decentralisatie kansen creëert voor bezitloos sloppenbewoners om over hun behoeftes te onderhandelen door middel van gekozen vertegenwoordigers via cliëntelisme, zijn deze vertegenwoordigers steeds ontvankelijker voor de behoeftes en ambities van de middenklasse, ten koste van de sloppenbewoners. Hierdoor worden de armen beroofd van hun politieke stem, ondanks de nieuwe politieke rechten die decentralisatie belooft.

Ten derde worden neoliberale stadsprojecten geïmplementeerd door semiautonome overheidsorganen, waarin beslissingen worden gemaakt door personen die geen directe verantwoordelijkheid afleggen aan het lokale electoraal of onder democratische controle staan. Informatie over stedelijke ontwikkelingsprojecten wordt niet, volgens de Right to Information Act, vrijgegeven aan het publiek en in het bijzonder niet aan de 'betrokken gemeenschap'. Ook al klinkt het woord decentralisatie goed voor politieke legitimiteit, het is juist een middel geworden voor de neoliberale lokale en centrale overheden om de elite en semiautonome organen te begunstigen via regelingen die niet-democratisch, ondoorzichtig en onduidelijk zijn.

Ten vierde dienen burgers uit de middenklasse massaal petities in voor ontruiming van sloppenwijken, bij rechtbanken in hun staat. Hierin bestempelen ze sloppen als 'hinderlijk' volgens Indiase milieuwetten, 
'onesthetisch', een belemmering voor de realisatie van een wereldklasse imago voor de steden en waarde verminderend van hun onroerend goed. Rechtbanken zijn vaak partijdig voor de middenklassen, weigeren het recht op onderdak voor de armen, en dragen bij aan verdere kapitaalgroei door de middenklasse.

In andere woorden, wezenlijk burgerschap wordt onsamenhangend en materieel gereconstitueerd op basis van armoede. Veel bezitloos sloppenbewoners worden gereconstitueerd als een 'onderlaag' met minder politieke en sociaaleconomische rechten dan huisbezitters en zitten in onzekerheid, een nieuwe vorm van verarming, door een gebrek aan informatie over het uitzettings- en verplaatsingsproces. Dit onderzoek stelt dat het gebrek aan transparantie van de lokale overheid richting sloppenbewoners tegengegaan kan worden door horizontale transparantie-initiatieven die momenteel worden nagestreefd door Slum Dwellers International, waardoor sociale relaties op basis van gelijkwaardigheid en vertrouwen in wereldwijde en lokale netwerken van sloppenbewoners mogelijk wordt. 


\section{Biography of the Author}

Sejal Patel studied Civil Engineering at L.D College of Engineering, Ahmedabad and Urban Planning at Centre For Environmental Planning and Technology (CEPT) University, Ahmedabad. After her studies she engaged in professional practice and research on urban planning and legislations, urban regeneration and gentrification policies, affordable housing policies and projects, slum redevelopment policies and projects and participatory governance as a Consultant to national, state and local governments, multilateral agencies and national and international research and academic institutions.

In 2006 she joined CEPT University, Ahmedabad as a faculty in the Faculty of Planning and is currently a Professor and Head, International Exchange Programs Office of the University. She teaches courses on urban landuse planning and legislations, affordable housing project, professional practice for urban planners (ethics and conduct) and studio on urban Development Plan, and housing plan and strategy. She has undertaken international studios on urban development plans in collaboration with universities in Srilanka, Thailand, Bhutan and Cardiff. In 2009 she was granted a fellowship by European Commission under it's Erasmus Mundus program for Doctoral research at ITC's PGM department.

\section{International peer reviewed Journals}

Patel, S., Sliuzas, R., \& Mathur, N. (2015). The risk of impoverishment in urban development-induced displacement and resettlement in Ahmedabad. Environment and Urbanization, 27(1), 231-256.

Patel, S., Sliuzas, R., \& Georgiadou, Y. (2016(forthcoming)). Participatory local governance in Asian cities: invited,closed or claimed spaces for urban poor?. Environment \& Urbanization Asia, 7(1).

Patel, S., \& Mandhyan, R. (2014). Impoverishment assessment of slum dwellers after off-site and on-site resettlement: a case of Indore. Commonwealth Journal of Local Governance, 15 (2), 104-127.

Dubagunta, G., \& Patel, S. (2016). Outreach of Pro-poor Housing Programs and Projects: Is it sustained? International Journal of Built Environment And Sustainability, 3(1), 365-373.

\section{National peer reviewed Journals/ Edited Book Section}

Dubagunta, G.S., \& Patel, S. (2015). Efforts of Affordable Housing Supply Models-Futile or Worthwhile? Shelter, 16(2), 18-27.

Patel, S., \& Bandyopadhyay, S. (2015). Conceptualising smart cities for unique urban development context of India. Nirman, 87(1), 30-38.

Mell, I., Patel, S., \& Bandyopadhyay, S. (2014). Smart Cities: What value will they bring to urban development in India? Shelter, 15(2), 77-90. 
Patel, S. (2016 (forthcoming)). The politics of land and Infrastructure development. In S. Patel (Ed.), Sociology. New Delhi: University Grants Commission, Ministry of Human Resource Development.

Patel, Sejal and Smruti Jukur. "Policy Response to Spatial Illegality, Displacement, Resettlemen and Impoverishment of Urban Poor." Shelter 17.2 (2016): 37-49

\section{International Conference Proceedings Papers (since 2011)}

Patel, K, \& Patel, S. (2016). Degree Of Citizen Participation In Participatory Local Governance: A Case Of Pune XVII Network-Association of European Researchers on Urbanisation in the South (NAERUS) Conference. Gothenburg: School of Public Administration, University of Gothenburg

Jukur, S.S., \& Patel, S. (2015). Government or Markets? An Evaluation of policy rhetoric and ongoing practices in Housing programs in Maharashtra. XVI Network-Association of European Researchers on Urbanisation in the South (N-AERUS) Conference. Dortmund: Technische Universität, Germany

Solanki, A., \& Patel, S. (2015). Diversity in urbanism characteristics of medium size twin towns. $\boldsymbol{X V I}$ Network-Association of European Researchers on Urbanisation in the South (N-AERUS) Conference. Dortmund: Technische Universität, Germany

Dubagunta, G. S., \& Patel, S. (2015). Outreach of pro-poor housing programs and projects: Is it sustained? 13th International Congress of Asian Planning Schools Association (APSA). Johor Bahru, Malaysia: Universiti Teknologi

Goyal, P., \& Patel, S. (2015). A framework for financing metro rail infrastructure through land value capture mechanisms : Case of Jaipur. 13th International Congress of Asian Planning Schools Association (APSA). Johor Bahru, Malaysia: Universiti Teknologi

Yadav, P., \& Patel, S. (2015). Sustainable city, Livable city, Global city or Smart City: what value addition does smart city bring to these paradigms in the context of global south? 13th International Congress of Asian Planning Schools Association (APSA). Johor Bahru, Malaysia Universiti Teknologi

Jukur, S.S., \& Patel, S. (2015). Government or Markets: Comparative Efficiency and Efficacy of Pro-poor housing supply mechanisms in India. 13th International Congress of Asian Planning Schools Association (APSA). Johor Bahru, Malaysia: Universiti Teknologi

Solanki, A., \& Patel, S. (2015). Non identical twin towns: Diversity in urbanism characteristics. 13th International Congress of Asian Planning Schools Association (APSA). Johor Bahru, Malaysia: Universiti Teknologi 
Patel, S. (2015). E-Learning: Opportunities, Issues and Challenges, International Workshop on 'E-Learning Methods and Instruments', GIZ India. New Delhi: GIZ India

Patel, S. (2014). Smart Cities: Discourse, Concepts and Potential of a travelling concept. International Conference on Smart Cities, Gujarat Technological University. Gandhinagar

Patel, S., \& Mandhyan, R. (2013). Improverishment assessment of slum dwellers after In situ and off-site relocations. XIV NetworkAssociation of European Researchers on Urbanisation in the South (N-AERUS) Conference. Enschede: ITC, Netherlands

Gupta, K., \& Patel, S. (2014). Long term prognosis of slum rehabilitation settlements in cities of global south: a failure or success? UK-Ireland Planning Research Conference. Oxford. Oxford Brooke's University

Patel, S. (2011). Community exclusions in slum upgradation programs in India: Empowerment through Judicial Interventions?. 11th International Congress of Asian Planning Schools Association (APSA). Tokyo: Tokyo University

Patel, S. (2011). Governance of slum upgradation programs: in the shadow of hierarchy? AESOP Young Academics. Delft: Technology University of Delft, Delft Netherlands

Patel, S. (2015). Smart Cities: Performance measurement, benchmarking and practices codes. National Conference on 'A global overview of Smart Cities in India' Ministry of Urban Development, Government of India, Gujarat Technological University Gandhinagar

Patel, S. (2015). Smart Cities: Debate on Definitions, Concepts and Performance Measurement Frameworks. National Workshop on 'Smart Cities: Prospects and Challenges', Department of Civil Engineering, PDPU. Gandhinagar: PDPU

\section{Invited lectures and presentations}

Patel, S. (2015). 100 Smart Cities and New Urban Development Mission of India. National Workshop on Developing Orientation Skills to Meet the Challenges of new Urban Development Missions. Government of Punjab-Haryana and Institute for Spatial Planning and Environment Research, India (ISPER).Chandigarh

Patel, S. (2015). Participatory local governance in Asian cities: invited, closed or claimed spaces for negotiations for the urban poor? National Seminar on 'Economic Development Across Sectors: Understanding Development Discourses', Department of Economics Maharaja Krishnakumarsinhji Bhavnagar University. Bhavnagar

Patel, S. (2014). Right to the City in the Neoliberal urban transformations. National Seminar on 'Economic Development Across Sectors: Discourses on Theories, Issues and Policies', Department of 
Economics Maharaja Krishnakumarsinhji Bhavnagar University. Bhavnagar

Patel, S. (2015). Smart Cities: Academic Response and Thematic Areas. International Workshop on Smart cities: Urban Utopias or the Future of Cities. Ahmedabad: Centre For Urban Equity, CEPT University September 2015. Potentials and Challenges of 100 Smart Cities Mission, MOUD. Public Lecture hosted by Faculty of Architecture, Urban and Town Planning, Deenbandhu Chhotu Ram University of Science \& Technology, State University of Haryana. Sonepat.

Patel, S. (2014). Urban Planning and Land Management Framework in India and Gujarat. International Training Program on Urban Planning, Infrastructure \& Service Delivery, of urban officials, CBUD, Ministry of Urban Development, Government of India., Ahmedabad, Singapore, Kuala Lampur and Melaka.

May, 2013. Urban Regeneration \& Displacement of the poor in Neoliberalising cities of global south. Public Lecture hosted by the Spatial Planning and City Environments Research Group, Cardiff University. Cardiff.

Patel, S. (2013). Urban Planning and Land Management Innovations in Gujarat. International Training Program of Elected wing on Urban Planning, Infrastructure \& Service Delivery, CBUD, Ministry of Urban Development, Government of India. Hyderabad, Ahmedabad and Singapore.

May 2015. Education and Practice in Urban Planning: Opportunities and Challenges. Public Lecture hosted by Gujarat Institute of Civil Engineers and Architects (GICEA), Ahmedabad.

September 2015. Journey through Doctoral Research: Proposal to Synthesis, Manuscript or Monographs, Publish or Perish. Ph.D Research Colloquium, CEPT University. Ahmedabad

August 2015. Urban Planning and Infrastructure Development in India: Framework, Potential and Challenges. Opening Lecture, B.Tech Program, Adani Institute of Infrastructure Engineering. Ahmedabad

September 2015. Approaches to increasing access to affordable shelter in urban India. National Institute of Cooperative Management (NICM), Gandhinagar

Patel, S. (2014). Positioning Urban poor in the Neoliberal Urban Development in India. Economics Conclave, Department of Economics, School of Liberal Studies, Pandit Deendyal Petroleum University (PDPU), Gandhinagar

Patel, S. (2014). Neoliberal Reforms and Urban Development: Inclusive or exclusionary growth? Refresher Course in Economics, Department of Economics under Academic Staff College, Gujarat University. Ahmedabad 
Patel, S. (2013). Approach to Developing Doctoral Research Proposal. Training Programme for Ph.D. Scholars, Academic Staff College, Gujarat University. Ahmedabad

December 11, 2012, Workshop on 'A Framework for Sustainable Sanitation Solutions' by Public Systems Group at the Indian Institute of Management (IIMA), Ahmedabad. 


\section{ITC Dissertation List}

https://www.itc.nl/Pub/research programme/Research-review-andoutput/PhD-Graduates 


\section{End Notes}

1 As per the exchange rate of 1 USD = INR 62.4 prevailing in mid-April 2015 when the research and analysis had concluded (http://www.xe.com/currencytables/?from=USD\&date=2015-04-15)

2 Semi structured interviews of academicians in urban planning and public policy from January to February 2015.

3 Discussions with Deputy Municipal Commissioner in November 2014.

4 Interview of ward officers of west zone and North West zone 6thand $11^{\text {th }}$ November 2014.

5 Interviews of members of two NGOs working with AMC on issues of slums in August 2014.

6 Semi structured interviews of middle class residents held from May 2014 to December 2014.

7 Semi structured interviews of slum leaders and residents held from May 2014 to December 2014.

8 Semi structured interviews of slum leaders and residents held from May 2014 to December 2014.

9 In AMC, the ruling party appoints a chief of zone from among the councilors of the constituent wards of the zone and the six such zonal party chiefs along with mayor and standing committee chairperson wield the most political power.

10 Interview of ward officers of west zone and North West zone 6thand 11th November 2014.

11 Interviews of ward officer of a ward in North West zone in February 2015.

12 Interview of municipal secretary in January 2015.

13 Semi structured interviews of academicians in urban planning and public policy from January to February 2015.

${ }^{14}$ AMC Resolution No.1274 dated 7/2/2005

${ }^{15}$ AMC Resolution No.426 dated 30/6/2005 and AMC Resolution No.346 dated 22/7/2005

${ }^{16}$ AMC Municipal Commissioner's letter to the Chief Secretary, GoG, dated $5 / 1 / 2006$, Number 719 requesting suspension of AMC Resolution Number 1274,426 and 346.

17 GoG Order Number AMN/902006/193/P dated 23/06/2006 suspending AMC Resolution Numbers 1274, 426 and 346.

18 Special Civil Application (SCA) No 23637 of 2007, in High Court of Gujarat, Petitioner: Jan Sangharsh Manch and Respondents: State of Gujarat and Ahmedabad Municipal Corporation.

${ }^{19}$ Special Civil Application (SCA) No 23637 of 2007, in High Court of Gujarat, Petitioner: Jan Sangharsh Manch and Respondents: State of Gujarat and Ahmedabad Municipal Corporation.

${ }^{20}$ Affidavit in reply by GoG to High Court dated 9/10/2007 in SCA No 23637 of 
2007

${ }^{21}$ Affidavit in reply by GoG to High Court dated 9/10/2007 in SCA No 23637 of 2007

22 Affidavit in reply by AMC to High Court, in High Court dated 8/7/2008 in SCA No 23637 of 2007

23 High Court final order dated 12/11/2008 in SCA No 23637 of 2007.

${ }^{24}$ Special Leave Petition (SLP) 2504 of 2009 in Supreme Court of India Petitioner: Jan Sangharsh Manch and Respondents: State of Gujarat and Ahmedabad Municipal Corporation.

${ }^{25}$ AMC Resolution No.265 dated 18/6/2009

${ }^{26}$ Interview of the civil rights activist involved in the petition in June 2015.

${ }^{27}$ Interview of a slum community leader in May 2015.

${ }^{28}$ Interview of senior officials and councilors of AMC in May 2015.

${ }^{29}$ SCA No 12331 of 2010, in High Court of Gujarat, Petitioner: Jan Sangharsh Manch and Respondents: State of Gujarat and Ahmedabad Municipal Corporation.

30 High Court final order dated 25/10/2010 in SCA No 12331 of 2010.

31 SCA No 2716 of 2001, in High Court of Gujarat, Petitioner : Ganeshnagar Nagrik Ekta Samiti and Respondents : Ahmedabad Municipal Corporation

32 High Court interim order dated 1/5/2001 in SCA No 2716 of 2001

${ }^{33}$ AMC Standing Committee Resolution No.543 dated 8/8/2001 and General Board Resolution No. 449 dated 28/9/2001

34 Kolkata is the capital of West Bengal; it has been governed by the Communist Party and therefore it is ironic that is no exception to this trend.

35 Interview with a resident slum dweller on Piplaj interim site, awaiting BSUP allotment, 17 June 2011

36 Notice for transfer to Piplaj sites and services plot, issued by Assistant estate officer of South Zone of AMC to the households to be displaced and resettled on the site.

37 Interview with senior AMC official1 September, 2010.

38 As per the exchange rate of 1 USD = INR 50 prevailing in March 2012 when the research and analysis had concluded (http://www.xe.com/currencytables/?from=INR\&date=2012-03-12)

39 Interview with senior AMC official, 1 September 2011.

40 Interview with senior staff member of NGO, 5 May 2011.

41 Focus group discussion with resettled community at the BSUP site Vadaj, 6 July 2011. 